\title{
Gestão de Resíduos
}

Sólidos
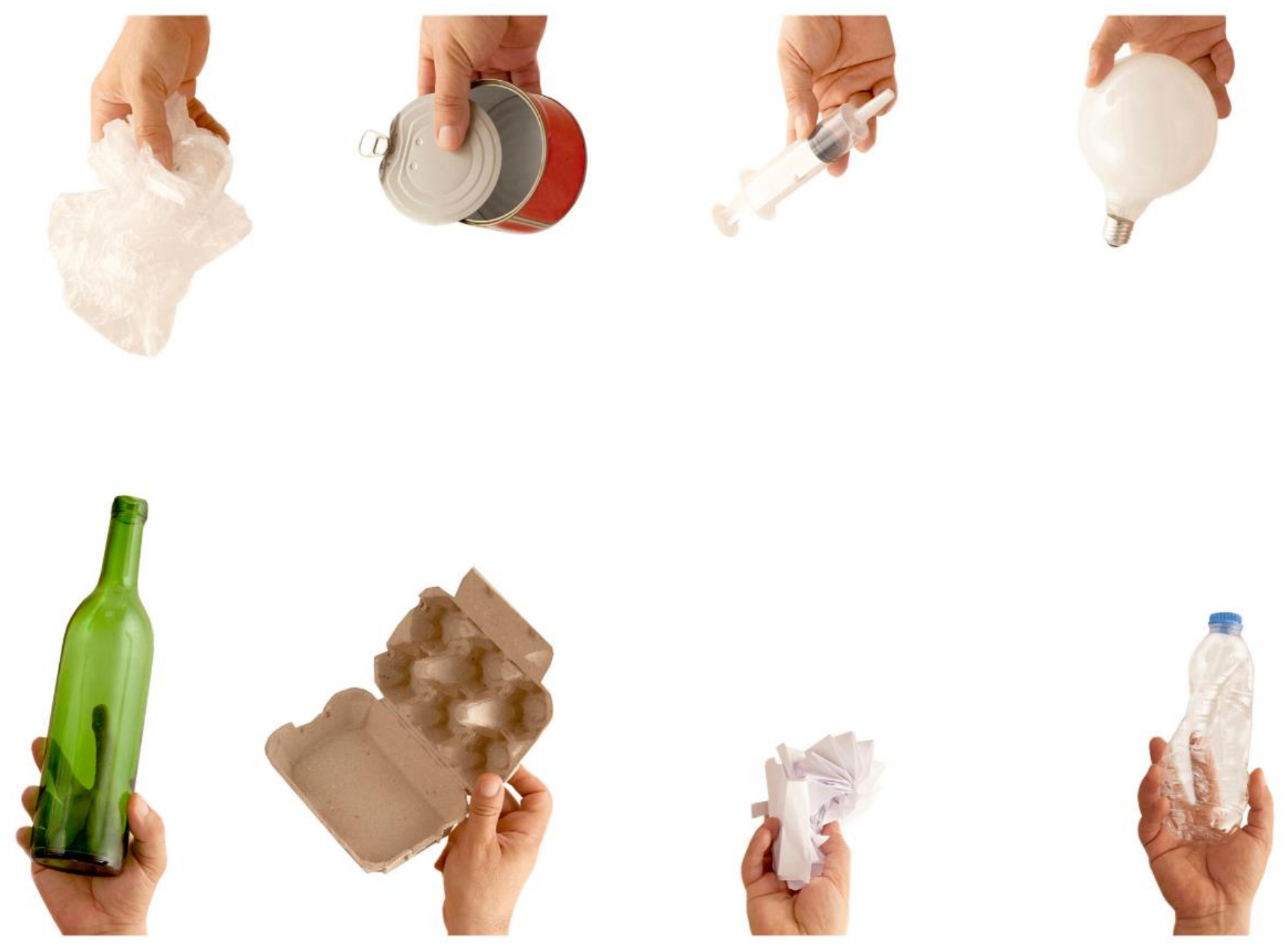

口秘品

,

ำ

咯数

Editora Poisson

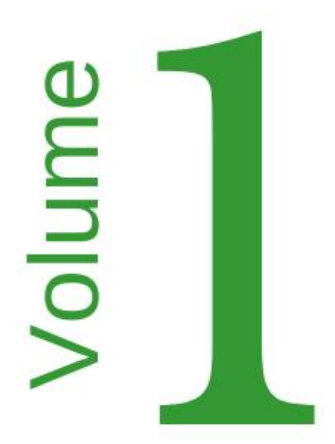


Editora Poisson

\section{Gestão de Resíduos Sólidos Volume 1}

1a Edição

Belo Horizonte

Poisson

2020 
Editor Chefe: Dr. Darly Fernando Andrade

\section{Conselho Editorial}

Dr. Antônio Artur de Souza - Universidade Federal de Minas Gerais

Ms. Davilson Eduardo Andrade

Dra. Elizângela de Jesus Oliveira - Universidade Federal do Amazonas

Msc. Fabiane dos Santos

Dr. José Eduardo Ferreira Lopes - Universidade Federal de Uberlândia

Dr. Otaviano Francisco Neves - Pontifícia Universidade Católica de Minas Gerais

Dr. Luiz Cláudio de Lima - Universidade FUMEC

Dr. Nelson Ferreira Filho - Faculdades Kennedy

Ms. Valdiney Alves de Oliveira - Universidade Federal de Uberlândia

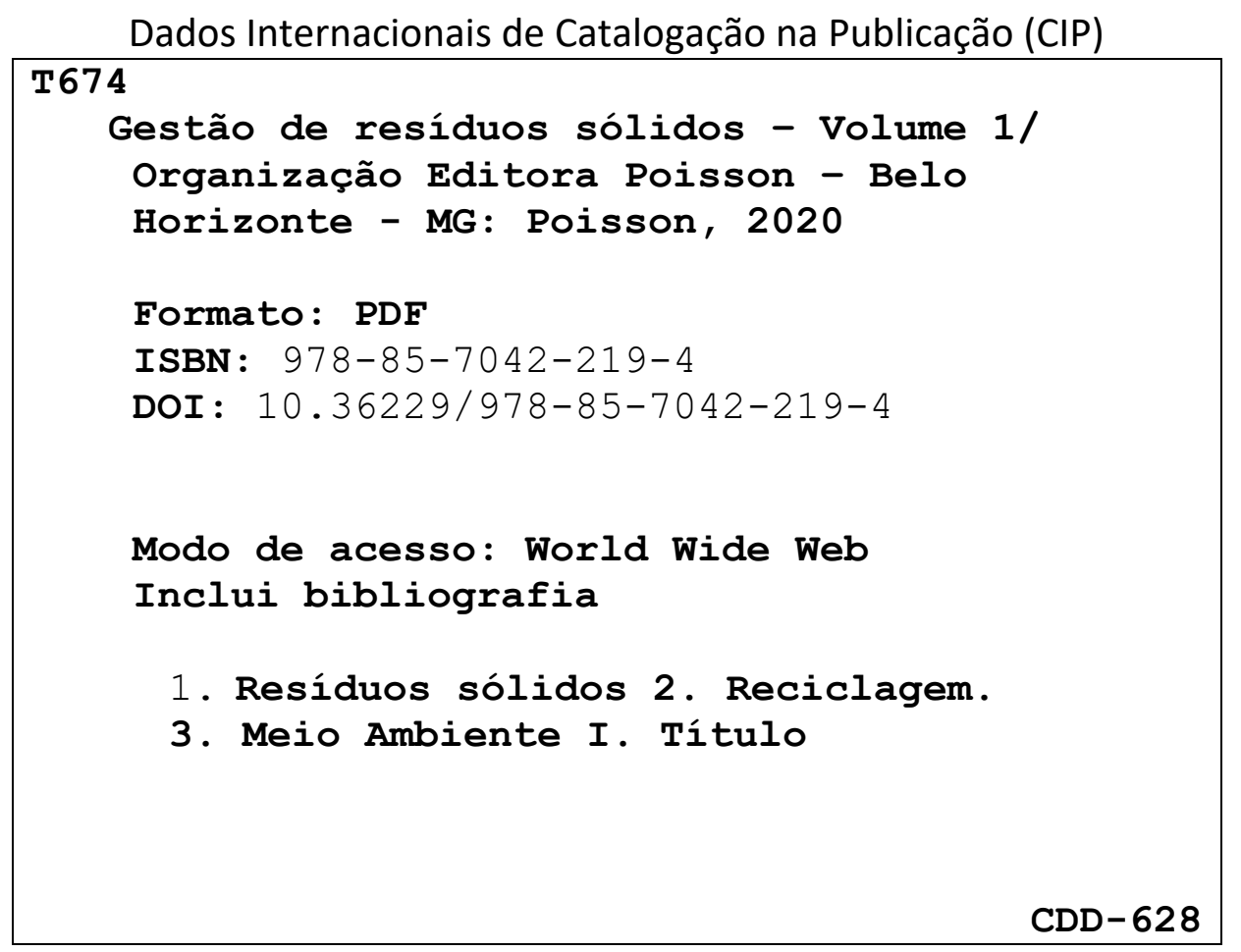

O conteúdo dos artigos e seus dados em sua forma, correção e confiabilidade são de responsabilidade exclusiva dos seus respectivos autores.

www.poisson.com.br

contato@poisson.com.br 


\section{SUMÁRIO}

Capítulo 1: Informação e conhecimento social das cidades no gerenciamento de resíduos sólidos. 07

Muira Helena Batista, Frederico Cordeiro Martins

DOI: 10.36229/978-85-7042-219-4.CAP.01

Capítulo 2: Análises gravimétricas como ferramenta de gestão dos resíduos sólidos dos setores 4, 15 e 16 de Poços de Caldas - MG

Leandro Henrique Pereira, Iago Cipriano Dutra, João Henrique Fernandes Oliveira, Luan Henrique Soares, Rafael de Oliveira Tiezzi

DOI: $10.36229 / 978-85-7042-219-4 . C A P .02$

Capítulo 3: Avaliação da composição gravimétrica dos resíduos sólidos urbanos da cidade de Xangri-Lá 16

Pâmela de Medeiros Engelmann, Gustavo Henrique Araújo dos Santos, Pedro Rocha da Rocha, Rogério Vescia Lourega, Jeane Estela Ayres de Lima DOI: $10.36229 / 978-85-7042-219-4 . C A P .03$

Capítulo 4: Avaliação do impacto da coleta seletiva na destinação final dos resíduos sólidos urbanos na cidade de Itabira-MG

Geraldo Ramos Madeira, Adenilson Evangelista Botelho, Eliane Maria Vieira

DOI: $10.36229 / 978-85-7042-219-4 . C A P .04$

Capítulo 5: Avaliação do ciclo de vida de cenários de gestão dos resíduos sólidos orgânicos no Distrito Federal.

Allan Luís Augusto Redes de Oliveira, Armando de Azevedo Caldeira Pires

DOI: 10.36229/978-85-7042-219-4.CAP.05

Capítulo 6: Resíduos sólidos no município de Juruti/PA, cenário atual e propostas para atendimento da Lei 12.305/2010, com aproveitmanto energetico para geração de energia elétrica.

Euller da Conceição Tavares, Elden de Albuquerque Marialva, Ana Lídia Picanço Moreira, Sostenes de Souza Moreira, Elinaldo Alves

DOI: $10.36229 / 978-85-7042-219-4 . C A P .06$

Capítulo 7: Avaliação da disposição dos Resíduos Sólidos Urbanos de Rebouças em Aterro Sanitário

Nathana Cipriano Ulchak, Ana Karoline Domiciano, Giovana Ranthum Viechneiski, Sílvia Carla da Silva André Uehara, Tatiane Bonametti Veiga

DOI: 10.36229/978-85-7042-219-4.CAP.07 


\section{SUMÁRIO}

Capítulo 8: Gestão de resíduos sólidos: Diretrizes de extensão universitária para a comunidade do Entorno da Escola Superior Pedagógica do Bié, em Angola. 44

Gaspar Sebastião Francisco Cristóvão, Gerson Araujo de Medeiros

DOI: $10.36229 / 978-85-7042-219-4 . C A P .08$

Capítulo 9: Transformação de resíduos de mineração em materiais de construção Estudo exploratório de abordagens.

Mônica da Cunha e Silva, Isabella Machado de Almeida

DOI: 10.36229/978-85-7042-219-4.CAP.09

Capítulo 10: Identificação das possíveis causas para o elevado índice de pós-obra em uma construtora certificada pela ABNT NBR ISO 9001 e SIAC: Um estudo de caso em obra de Condomínio Horizontal.

Taciane Strickler Dutra

DOI: $10.36229 / 978-85-7042-219-4 . C A P .10$

Capítulo 11: Implantação de usina de reciclagem de resíduos da construção civil em Município de Médio Porte 68

Alyson Rodrigues Amaral, Adriana Antunes Lopes, Alexandra Fátima Saraiva Soares DOI: $10.36229 / 978-85-7042-219-4 . C A P .11$

Capítulo 12: Análise da adição do resíduo Cal de Carbureto no concreto. 81

Julianna Muller da Silva, Fernando de Farias Fernandes

DOI: $10.36229 / 978-85-7042-219-4 . C A P .12$

Capítulo 13: Estudo da utilização do resíduo de Caulim como substituto parcial do agregado miúdo na produção de concreto para intertravados 85

Thyago Lima Souza, Maria Isabel de Araújo Nóbrega, Fellipe Dalyson Gadelha Silva, Thiago da Nóbrega Sousa, Larissa Santana Batista

DOI: $10.36229 / 978-85-7042-219-4 . C A P .13$

Capítulo 14: Contribuição na melhoria do processo de tratamento do óleo de fritura em operação em Indústria Domissanitária.

Ivan Xavier Lins, Flávia Moura de Moraes, Mohand Benachour

DOI: $10.36229 / 978-85-7042-219-4 . C A P .14$

Capítulo 15: Questionário para diagnóstico do gerenciamento do óleo de cozinha residual

Ana Karoline Domiciano, Giovana Ranthum Viechneiski, Nathana Cipriano Ulchak, Mariane Viviurka Fernandes, Silvia Carla da Silva André Uehara, Tatiane Bonametti Veiga

DOI: $10.36229 / 978-85-7042-219-4 . C A P .15$ 


\section{SUMÁRIO}

Capítulo 16: Otimização e conservação dos recursos hídricos por meio de práticas de reuso de águas residuarias em oficina de manutenção de locomotivas. 109

Demerson Fernandes Silva, Dirceu José dos Santos Júnior, Halison Salis Eustáquio, Páglia Silva Lopes Santos, Hygor Aristides Victor Rossoni

DOI: $10.36229 / 978-85-7042-219-4 . C A P .16$

Capítulo 17: A logística reversa de embalagens de lubrificantes automotivos no Brasil: 0 cenário atual e as exigências da Política Nacional de Resíduos Sólidos 113

Harley Moraes Martins, Michelle Ramos Cavalcante Fortunato, Gustavo Simas Pereira, Hudson Santos da Silva

DOI: 10.36229/978-85-7042-219-4.CAP.17

Autores: 


\section{Capítulo 1}

\section{Informação e conhecimento social das cidades no gerenciamento de resíduos sólidos}

\section{Muira Helena Batista}

Frederico Cordeiro Martins

Resumo: Trata-se de um ensaio teórico para compreensão das contribuições científicas da ciência da informação e do conhecimento na vivência social das cidades como instrumento voltado para sustentabilidade ambiental e que preencha as lacunas omissivas das instituições, Institutional Void, no tocante às políticas públicas da gestão de resíduos sólidos. É problematizado a partir dos transtornos vivenciados pelas cidades em relação aos resíduos sólidos, nas omissões da gestão ambiental do poder público municipal e na necessidade de desenvolvimento sustentável. Para elaboração, além da literatura clássica, foram estudados artigos publicados em periódicos, levantados por procedimento de busca no Portal de Periódicos da CAPES e da Scielo, com termos combinados a partir da utilização de operadores Booleanos, em português, inglês e espanhol, nos últimos cinco anos, considerados apenas os artigos cujo texto completo estivesse disponível. A pesquisa possibilitou estabelecer uma relação entre os temas para criar uma base conceitual necessária ao desenvolvimento de estudos empíricos futuros voltados para a sustentabilidade ambiental a partir da informação e do conhecimento na vivência social.

Palavras-chave: Informação, conhecimento, cidades, Institutional Void e resíduos sólidos. 


\section{INTRODUÇÃO}

Na atualidade, as cidades vêm apresentando um exponencial crescimento nos problemas ambientais relacionados com as suas atividades econômicas, interações sociais e culturais em face de diversos fatores como o crescimento populacional e o aumento do consumo, o que faz com que as questões ambientais recebam especial atenção das políticas nacionais e internacionais, bem como aquelas de caráter regional e institucional, com objetivo de mitigar os efeitos da produção e consumo no meio-ambiente e alcançar a sustentabilidade ambiental.

Segundo dados fornecidos pela Organização das Nações Unidas-ONU, em 1950 a população mundial era estimada em cerca de 2,6 bilhões de pessoas, em 1990, 5,3 bilhões e, em 2015, 7,3 bilhões, com projeção de duplicação para 2050 (ONU, 2016, p. 3) ou seja, uma expansão rápida que traz importantes implicações na vida das pessoas e suas relações com o ambiente onde vivem, principalmente à consideração de que a geração total de resíduos sólidos urbanos no Brasil atingiu um total de 214.868 toneladas diárias em 2017 (Abrelpe, 2017, p. 15).

Esta constatação conduz ao fato de que a gestão do lixo é um problema mundial que clama por soluções urgentes. As cidades precisam de uma gestão eficiente de resíduos sólidos para garantir um ambiente capaz de abrigar toda sua população sem riscos, tema pautado como prioritário nas agendas locais que vem buscando por meio da informação e do conhecimento desenvolver técnicas inovadoras de gestão ambiental, embora em pouca sintonia com os cidadãos, cuja articulação se torna fundamental para o sucesso das políticas públicas destinadas a este setor.

Diante deste cenário, surge a importância de se verificar a relação das cidades com os resíduos sólidos e seu gerenciamento, em especial quanto à adoção de abordagens baseadas nas tecnologias de informação e conhecimento que transformem as políticas públicas ambientais em planejamento, ação, controle e avaliação.

Objetiva-se com esse trabalho compreender quais são as contribuições científicas da ciência da informação no tocante às políticas públicas da gestão de resíduos sólidos.

\section{METODOLOGIA}

Para elaboração do ensaio teórico, foi realizada uma revisão da literatura embasada no objetivo principal, mediante o uso de palavras chaves em processos de busca estruturada em bases científicas que reúnem de maneira ordenada diversos estudos que tratam das questões aqui pesquisadas, sua correlação entre as várias teorias, para gerar um arcabouço de informações que venha auxiliar os futuros estudos, identificando os conteúdos, métodos e tendências das publicações (WENDLER, 2012).

No procedimento de busca foi utilizada a biblioteca digital, Portal de Periódicos da CAPES e a Plataforma Scielo, com aplicação de operadores lógicos Booleanos, nos idiomas português, inglês e espanhol, no período compreendido entre os últimos cinco anos, considerando apenas os artigos cujo texto completo estivesse disponível.

A partir de uma leitura sistemática dos conteúdos utilizou-se como critérios de exclusão ou inclusão, aqueles que apresentavam contribuições científicas relativas às ciências da informação e gestão do conhecimento, conceitos teóricos clássicos, dos problemas enfrentados pelas cidades no gerenciamento de resíduos sólidos e na sua ausência por parte das instituições políticas (Institutional Voids), nos mecanismos de transferência de informação e conhecimento social e na sustentabilidade ambiental.

\section{RESULTADOS E DISCUSSÃO}

O estudo dos artigos possibilitou estabelecer uma correlação entre os termos, numa construção interdisciplinar de investigação detalhada do compartilhamento de pesquisas, experiências, objetivos e problemas como resposta às transformações sociais, políticas, culturais e tecnológicas que visam o aprimoramento das técnicas e instrumentos de aplicação prática em ciência, tecnologia e inovação na solução de problemas em diversos níveis, o que se encontra sintetizado na tabela 1.

São estudos científicos que contribuem para a ciência da informação e apontam para uma crescente participação política dos sujeitos que contribuem para a gestão de resíduos sólidos nas cidades a partir de sua vivência social, preenchendo as lacunas omissivas das instituições na elaboração de políticas públicas que garantam a sustentabilidade ambiental. 
Tabela 1 - Principais contribuições científicas da ciência da informação na vivência social das cidades (Elaborada pelos autores)

\begin{tabular}{|c|c|c|c|c|c|c|}
\hline & TÍTULO & AUTORES & PUBLICAÇÃO & $\begin{array}{l}\text { OBJETIVO/FOCO DO } \\
\text { ESTUDO }\end{array}$ & METODOLOGIA & $\begin{array}{l}\text { PRINCIPAIS } \\
\text { CONSTRUTOS }\end{array}$ \\
\hline 1 & $\begin{array}{l}\text { A proteção } \\
\text { ambiental e a } \\
\text { gestão } \\
\text { compartilhada: } \\
\text { um estudo de caso } \\
\text { na Região } \\
\text { Metropolitana de } \\
\text { Natal }\end{array}$ & $\begin{array}{l}\text { Raquel Maria da } \\
\text { Costa Silveira } \\
\text { Fábio Fonseca } \\
\text { Figueiredo } \\
\text { Jelisse Vieira } \\
\text { Gomes Almeida }\end{array}$ & $\begin{array}{l}\text { Cad. Metrop., São Paulo, v. 20, } \\
\text { n. } 42 \text {, pp. 513-530, maio/ago } \\
2018 \\
\text { http://dx.doi.org/10.1590/22 } \\
\text { 36-9996.2018-4210 }\end{array}$ & $\begin{array}{l}\text { Refletir acerca da } \\
\text { relação entre a Política } \\
\text { Nacional de Resíduos } \\
\text { Sólidos e o Estatuto da } \\
\text { Metrópole, } \\
\text { compreendendo as } \\
\text { implicações e os } \\
\text { desafios previstos } \\
\text { nessas normas para as } \\
\text { regiões metropolitanas } \\
\text { no Brasil }\end{array}$ & $\begin{array}{l}\text { Estudo de caso na } \\
\text { Região } \\
\text { Metropolitana de } \\
\text { Natal (RMN) }\end{array}$ & $\begin{array}{l}\text { Desafios da } \\
\text { gestão } \\
\text { metropolitana no } \\
\text { Brasil Política } \\
\text { nacional de } \\
\text { resíduos sólidos e } \\
\text { suas implicações } \\
\text { nas regiões } \\
\text { metropolitanas. }\end{array}$ \\
\hline 2 & $\begin{array}{l}\text { Gestão de } \\
\text { resíduos sólidos } \\
\text { urbanos nos } \\
\text { municípios da } \\
\text { Bacia Hidrográfica } \\
\text { do Alto Tietê: uma } \\
\text { análise sobre o } \\
\text { uso de TIC no } \\
\text { acesso à } \\
\text { informação } \\
\text { governamental }\end{array}$ & $\begin{array}{l}\text { Flávio Bordino } \\
\text { Klein Sylmara } \\
\text { Lopes Francelino } \\
\text { GonçalvesDias } \\
\text { Martin Jayo }\end{array}$ & $\begin{array}{l}\text { Revista Brasileira de Gestão } \\
\text { Urbana (Brazilian Journal of } \\
\text { Urban Management), } 2018 \\
\text { jan./abr., 10(1), 140-153 }\end{array}$ & $\begin{array}{l}\text { Analisar de que forma } \\
\text { tecnologias de } \\
\text { informação e } \\
\text { comunicação (TIC), e a } \\
\text { internet em particular, } \\
\text { são empregadas para } \\
\text { apoiar a gestão de } \\
\text { resíduos sólidos } \\
\text { urbanos (RSU) no nível } \\
\text { municipal }\end{array}$ & $\begin{array}{l}\text { Pesquisa } \\
\text { exploratória, de } \\
\text { natureza } \\
\text { qualitativa. }\end{array}$ & $\begin{array}{l}\text { Resíduos sólidos } \\
\text { urbanos, } \\
\text { impactos } \\
\text { ambientais e } \\
\text { estratégias de } \\
\text { gestão. Governo } \\
\text { eletrônico e o } \\
\text { acesso à } \\
\text { informação }\end{array}$ \\
\hline 3 & $\begin{array}{l}\text { Contribuições } \\
\text { para a evolução } \\
\text { do gerenciamento } \\
\text { de resíduos } \\
\text { sólidos urbanos } \\
\text { no Brasil com } \\
\text { base na } \\
\text { experiência } \\
\text { Européia } \\
\end{array}$ & $\begin{array}{l}\text { Camille Ferreira } \\
\text { Mannarino João } \\
\text { Alberto Ferreira } \\
\text { Mauro Gandolla }\end{array}$ & $\begin{array}{l}\text { Eng Sanit Ambient | v.21 n.2 | } \\
\text { abr/jun 2016 | 379-385 }\end{array}$ & $\begin{array}{l}\text { Apresentar dados } \\
\text { relevantes sobre o } \\
\text { gerenciamento de } \\
\text { resíduos sólidos } \\
\text { urbanos (RSU) na } \\
\text { Europa de forma a se } \\
\text { estabelecer paralelos e } \\
\text { subsidiar a discussão no } \\
\text { Brasil. }\end{array}$ & $\begin{array}{l}\text { Não foi } \\
\text { esclarecida } \\
\text { corretamente }\end{array}$ & $\begin{array}{l}\text { Gestão de } \\
\text { resíduos sólidos } \\
\text { como parte do } \\
\text { planejamento } \\
\text { urbano. }\end{array}$ \\
\hline 4 & $\begin{array}{l}\text { Social innovation } \\
\text { as a process to } \\
\text { overcome } \\
\text { institutional } \\
\text { voids: a } \\
\text { multidimensional } \\
\text { overview } \\
\text { Inovação social } \\
\text { como processo de } \\
\text { superação de } \\
\text { vazios } \\
\text { institucionais: } \\
\text { uma visão } \\
\text { multidimensional }\end{array}$ & $\begin{array}{l}\text { MANUELA } \\
\text { RÖSING } \\
\text { AGOSTINI } \\
\text { LUCIANA } \\
\text { MARQUES } \\
\text { VIEIRA MARILIA } \\
\text { BONZANINI } \\
\text { BOSSLE }\end{array}$ & $\begin{array}{l}\text { RAM, REV. ADM. MACKENZIE, } \\
\text { (Mackenzie Management } \\
\text { Review) } 17(6), \text { Special } \\
\text { Edition • SÃO PAULO, SP • } \\
\text { NOV./DEC. } 2016 \bullet \text { ISSN 1518- } \\
6776 \text { (printed version) • ISSN } \\
1678-6971\end{array}$ & $\begin{array}{l}\text { Propose a theoretical } \\
\text { framework to explore } \\
\text { social innovation as a } \\
\text { response to institutional } \\
\text { voids in a } \\
\text { multidimensional } \\
\text { analysis. Propor um } \\
\text { quadro teórico para } \\
\text { explorar a inovação } \\
\text { social como uma } \\
\text { resposta a vazios } \\
\text { institucionais em uma } \\
\text { análise } \\
\text { multidimensional. }\end{array}$ & $\begin{array}{l}\text { Literature } \\
\text { review. Revisão } \\
\text { de literatura. }\end{array}$ & $\begin{array}{l}\text { Social Innovation. } \\
\text { Inovação social. }\end{array}$ \\
\hline 5 & $\begin{array}{l}\text { Construindo } \\
\text { governança } \\
\text { eletrônica de } \\
\text { cidades.Um } \\
\text { modelo de } \\
\text { implementação de } \\
\text { soluções para } \\
\text { inovação e } \\
\text { otimização da } \\
\text { gestão pública }\end{array}$ & $\begin{array}{l}\text { Gilberto dos } \\
\text { Santos Madeira } \\
\text { Tor Guimaraes } \\
\text { Leonardo de } \\
\text { Souza Mendes }\end{array}$ & $\begin{array}{l}\text { Revista de GESTÃO dos Países } \\
\text { de Língua Portuguesa }\end{array}$ & $\begin{array}{l}\text { Desenvolver e propor } \\
\text { um modelo para } \\
\text { implementação de } \\
\text { governança eletrônica } \\
\text { de cidades }\end{array}$ & $\begin{array}{l}\text { Exploratória } \\
\text { sequencial }\end{array}$ & $\begin{array}{l}\text { Efetividade da } \\
\text { implementação } \\
\text { de inovação } \\
\text { municipal }\end{array}$ \\
\hline
\end{tabular}


(continuação ...)

Tabela 1 - Principais contribuições científicas da ciência da informação na vivência social das cidades

\begin{tabular}{|c|c|c|c|c|c|c|}
\hline & TÍTULO & AUTORES & PUBLICAÇÃO & OBJETIVO/FOCO DO ESTUDO & $\begin{array}{c}\text { METODOLO } \\
\text { GIA }\end{array}$ & $\begin{array}{l}\text { PRINCIPAIS } \\
\text { CONSTRUTOS }\end{array}$ \\
\hline 6 & $\begin{array}{l}\text { Factores de } \\
\text { desarrollo de } \\
\text { las ciudades } \\
\text { inteligentes }\end{array}$ & $\begin{array}{l}\text { Dorota } \\
\text { Sikora - } \\
\text { Fernández }\end{array}$ & $\begin{array}{l}\text { Revista Universitaria de } \\
\text { Geografía / ISSN 0326-8373 / } \\
2017,26 \text { (1), 135-152 }\end{array}$ & $\begin{array}{l}\text { Responder a las preguntas } \\
\text { acerca de cuáles son los } \\
\text { factores de la creación y } \\
\text { funcionamiento de las ciudades } \\
\text { inteligentes y si es una } \\
\text { necesidad para el desarrollo de } \\
\text { áreas banizadas o bien, si es } \\
\text { una nueva moda para poner } \\
\text { una etiqueta a la ciudad, } \\
\text { utilizada por las autoridades } \\
\text { locales, para crear una imagen } \\
\text { de la misma }\end{array}$ & $\begin{array}{l}\text { Estudo de } \\
\text { caso }\end{array}$ & $\begin{array}{l}\text { Soluciones } \\
\text { inteligentes }\end{array}$ \\
\hline 7 & $\begin{array}{l}\text { A agregação } \\
\text { das } \\
\text { Tecnologias de } \\
\text { Informação e } \\
\text { Comunicação } \\
\text { ao espaço } \\
\text { público } \\
\text { urbano: } \\
\text { reflexões em } \\
\text { torno do } \\
\text { Projeto } \\
\text { CyberParks } \\
\end{array}$ & $\begin{array}{l}\text { Carlos } \\
\text { Smaniotto } \\
\text { Costa } \\
\text { Marluci } \\
\text { Menezes }\end{array}$ & $\begin{array}{l}\text { Revista Brasileira de Gestão } \\
\text { Urbana (Brazilian Journal of } \\
\text { Urban Management), } 2016 \\
\text { set./dez., 8(3), 332-344 }\end{array}$ & $\begin{array}{l}\text { Investigar a contribuição das } \\
\text { TIC na transformação das } \\
\text { cidades em contextos mais } \\
\text { inclusivos, e não somente mais } \\
\text { high tech. }\end{array}$ & $\begin{array}{l}\text { Estudo de } \\
\text { caso }\end{array}$ & $\begin{array}{l}\text { Análise de } \\
\text { Projeto } \\
\text { denominado } \\
\text { CyberParks }\end{array}$ \\
\hline 8 & $\begin{array}{l}\text { INFORMAÇÃO, } \\
\text { CIDADE E } \\
\text { CONHECIMEN } \\
\text { TO: POR UMA } \\
\text { ABORDAGEM } \\
\text { DO ESPAÇO } \\
\text { URBANO }\end{array}$ & $\begin{array}{l}\text { SILVIO JOSÉ } \\
\text { CONCEIÇÃO }\end{array}$ & $\begin{array}{l}\text { http://www.cinformanteriore } \\
\text { s.ufba.br/v_anais/a } \\
\text { rtigos/silviojoseconceicao.ht } \\
\text { ml }\end{array}$ & $\begin{array}{l}\text { Propor uma visão em rede do } \\
\text { objeto cidade a partir de } \\
\text { reflexões acerca dos fluxos de } \\
\text { informação ger(i)(a)dos no } \\
\text { espaço urbano como } \\
\text { possibilidade para a } \\
\text { construção do conhecimento }\end{array}$ & $\begin{array}{l}\text { Revisão de } \\
\text { literatura }\end{array}$ & $\begin{array}{l}\text { Informação, } \\
\text { cidade, } \\
\text { conhecimento } \\
\text { redes, } \\
\text { espaços de } \\
\text { fluxos e } \\
\text { abordagem } \\
\text { urbana. }\end{array}$ \\
\hline 9 & $\begin{array}{l}\text { LUGARES E } \\
\text { ESPAÇOS DA } \\
\text { CIDADE: } \\
\text { artefatos infor- } \\
\text { comunicaciona } \\
\text { is } \\
\text { memorialístico } \\
\mathrm{s}\end{array}$ & $\begin{array}{l}\text { Tahis } \\
\text { Virginia } \\
\text { Gomes da } \\
\text { Silva Maria } \\
\text { Nilza } \\
\text { Barbosa } \\
\text { Rosas José } \\
\text { Mauro } \\
\text { Matheus } \\
\text { Loureiro }\end{array}$ & $\begin{array}{l}\text { XIX ENCONTRO NACIONAL DE } \\
\text { PESQUISA EM CIÊNCIA DA } \\
\text { INFORMAÇÃO - ENANCIB } \\
2018\end{array}$ & $\begin{array}{l}\text { Apresentar uma reflexão sobre } \\
\text { as inter-relações dialógicas do } \\
\text { binômio "informação e } \\
\text { memória". }\end{array}$ & $\begin{array}{l}\text { Revisão de } \\
\text { literatura }\end{array}$ & $\begin{array}{l}\text { MEMÓRIA: } \\
\text { referenciame } \\
\text { nto } \\
\text { INFORMAÇÃo } \\
\text { : } \\
\text { representaçã } \\
\text { o CULTURA: } \\
\text { artefatos A } \\
\text { CIDADE: } \\
\text { múltiplos } \\
\text { lugares e } \\
\text { espaços de } \\
\text { memória }\end{array}$ \\
\hline $\begin{array}{l}1 \\
0\end{array}$ & $\begin{array}{l}\text { A contribuição } \\
\text { das redes } \\
\text { sociais na } \\
\text { elaboração de } \\
\text { políticas } \\
\text { públicas } \\
\text { participativas }\end{array}$ & $\begin{array}{l}\text { Andrés } \\
\text { Burgos } \\
\text { Delgado } \\
\text { Diana Rocío } \\
\text { Rodríguez } \\
\text { Triana Doris } \\
\text { Aleida } \\
\text { Villamizar } \\
\text { Sayago }\end{array}$ & $\begin{array}{l}\text { Encontro Internacional } \\
\text { Participação, Democracia e } \\
\text { Políticas Públicas: } \\
\text { aproximando agendas e } \\
\text { agentes } 23 \text { a } 25 \text { de abril de } \\
2013, \text { UNESP, Araraquara (SP) }\end{array}$ & $\begin{array}{l}\text { Analisar as políticas públicas } \\
\text { desde a perspectiva relacional } \\
\text { das redes sociais, apresentando } \\
\text { os principais aspectos } \\
\text { metodológicosconceituais } \\
\text { embasados na abordagem da } \\
\text { policy network, de modo a } \\
\text { contribuir para o debate sobre } \\
\text { participação, democracia e } \\
\text { políticas públicas, desde o } \\
\text { reconhecimento da } \\
\text { importância das relações } \\
\text { sociais. }\end{array}$ & $\begin{array}{l}\text { Revisão de } \\
\text { literatura }\end{array}$ & $\begin{array}{l}\text { O processo de } \\
\text { formulação } \\
\text { de políticas } \\
\text { públicas A } \\
\text { teoria de } \\
\text { redes sociais } \\
\text { Policy } \\
\text { network } \\
\text { Governança e } \\
\text { políticas } \\
\text { públicas A } \\
\text { participação } \\
\text { social na } \\
\text { gestão de } \\
\text { políticas } \\
\text { públicas }\end{array}$ \\
\hline
\end{tabular}




\section{CONSIDERAÇÕES FINAIS}

A geração de resíduos sólidos é tema problemático e gravemente preocupante que coloca as cidades e as pessoas no centro das discussões e faz com que se tornem cada vez mais protagonistas de mudança nos cenários sociais e políticos por meios tecnológicos e redes de informação e conhecimento para preencher as lacunas deixadas pelo poder público. Exemplo disto é o chamado "desafio do lixo" em inglês "trashtag challenge", onde as pessoas são motivadas à prática de ações de limpeza de locais que acumulam certa quantidade de lixo, postando nas redes sociais o "antes" e "depois". Destacam-se, também, ações voltadas para a conscientização, redução, adequação do consumo, descarte, como os perfis do Instagram "Um ano sem lixo", "Por favor menos lixo", "Jornada zero waste" etc. Assim verificamos que existem diversas abordagens da vivência social nas cidades que, baseadas nas tecnologias de informação e conhecimento, transformam as políticas públicas ambientais em planejamento, ação, controle e avaliação.

\section{REFERÊNCIAS}

[1] Agostini, Manuela Rösing; Vieira, Luciana Marques; Bossle, Marilia Bonzanini. Social innovation as a process to overcome institutional voids: a multidimensional overview. RAM, Rev. Adm. Mackenzie, São Paulo, v. 17, n. 6, p. 72-101, Dec. 2016. Disponível em <http://www.scielo.br/scielo.php?script=sci_arttext\&pid=S1678$69712016000600072 \& \operatorname{lng}=$ en\&nrm=iso $>$. Acesso em 08 mar. 2019.

[2] Associação Brasileira de Empresas de Limpeza Pública e Resíduos Especiais - Abrelpe. Panorama 2017. Disponível em http://abrelpe.org.br/download-panorama-2017/. Acesso em 20 de nov. 2018.

[3] Conceição, Silvio José. Informação, cidade e conhecimento: Por uma abordagem do espaço urbano.Disponível em http://www.cinform-anteriores.ufba.br/v_anais/artigos/silviojoseconceicao.html. Acesso em 05 out.2018.

[4] Costa, Carlos Smaniotto; Menezes, Marluci. A agregação das Tecnologias de Informação e Comunicação ao espaço público urbano: reflexões em torno do Projeto CyberParks - COST TU 1306. urbe, Rev. Bras. Gest. Urbana, Curitiba , v. 8, n. 3, p. 332-344, Dec. 2016 . Disponível em <http://www.scielo.br/scielo.php?script=sci_arttext\&pid=S2175-33692016000300332\&lng=en\&nrm=iso>. Acesso em 08 mar. 2019.

[5] Madeira, Gilberto dos Santos; Guimaraes, Tor; Mendes, Leonardo de Souza. Construindo governança eletrônica de cidades: Um modelo de implementação de soluções para inovação e otimização da gestão pública. RGPLP, Lisboa ， v. 16, n. 2, p. 55-71, set. 2017 . Disponível em <http://www.scielo.mec.pt/scielo.php?script=sci_arttext\&pid=S1645-44642017000200005\&lng=pt\&nrm=iso>. Acesso em 08 mar. 2019.

[6] Mannarino, Camille Ferreira; Ferreira, João Alberto; Gandolla, Mauro. Contribuições para a evolução do gerenciamento de resíduos sólidos urbanos no Brasil com base na experiência Europeia. Eng Sanit Ambient | v.21 n.2 | abr/jun 2016 | 379-385. Disponível em http://www.scielo.br/pdf/esa/2016nahead/1809-4457-esaS1413_41522016146475.pdf. Acesso em 08 mar. 2019.

[7] Organização das Nações Unidas-Onu. Nova Agenda Urbana. Disponível em : http://habitat3.org/the-newurban-agenda/. Acesso em 14 de setembro de 2018.

[8] Silva, Tahis Virginia Gomes da; Rosas, Maria Nilza Barbosa; Loureiro José Mauro Matheus. Lugares e Espaços da Cidade: artefatos infor-comunicacionais memorialísticos. Disponível em http://enancib.marilia.unesp.br/index.php

[9] /Xixenancib/xixenancib/paper/view/1296. Acesso em 08 mar. 2019.

[10] Silveira, Raquel Maria da Costa; Figueiredo, Fábio Fonseca; Almeida, Jelisse Vieira Gomes. A proteção ambiental e a gestão compartilhada: um estudo de caso na Região Metropolitana de Natal. Cad. Metrop., São Paulo, v. 20, n. 42, p. 513-530, ago. 2018 . Disponível em <http://www.scielo.br/scielo.php?script=sci_arttext\&pid=S223699962018000200513\&lng=pt\&nrm=iso>. acesso em 08 mar. 2019

[11] Wendler, R. The maturity of maturity model research: A systematic mapping study. Information and software technology, v. 54, n. 12, p. 1317-1339, 2012. Disponível em: http://www.sciencedirect.com/science/article/pii/S0950584912001334. Acesso em: 23 mar. 2019. 


\title{
Capítulo 2
}

\section{Análises gravimétricas como ferramenta de gestão dos resíduos sólidos dos setores 4, 15 e 16 de Poços de Caldas - MG}

\author{
Leandro Henrique Pereira \\ Iago Cipriano Dutra \\ João Henrique Fernandes Oliveira \\ Luan Henrique Soares \\ Rafael de Oliveira Tiezzi
}

Resumo: Com o crescimento da população, a geração de resíduos sólidos urbanos (RSU) aumentou consideravelmente, sendo necessário caracterizá-los para ter o tratamento e o destino final adequado. Isto é realizado por meio da análise gravimétrica, que obtém a composição média de cada tipo de resíduo. Em Poços de Caldas-MG não há tais dados atualizados, o que facilitaria a ter maior controle e gerenciamento de resíduos sólidos. Por isso, foram feitas análises gravimétricas dos setores 4, 15 e 16 da cidade, bem como a comparação socioeconômica de cada setor gerador por meio da renda domiciliar per capita. Verificou-se que os RSUs são compostos principalmente por matéria orgânica, sendo que apresentou porcentagem de $43,00 \%, 48,15 \%$ e $58,86 \%$, respectivamente, sendo possível realizar a compostagem na etapa de tratamento destes resíduos. Ressalta-se que o setor 16 apresentou maior geração de matéria orgânica e pode ter relação com o maior nível de renda per capita, pois há maior consumo de alimentos e, consequentemente, maior geração de resíduos. Ainda, notou-se a baixa geração de resíduos recicláveis, que se torna um desafio para a cooperativa Ação Reciclar. Este trabalho foi importante para identificar a composição de resíduos gerados nestes setores, pois é fundamental para um gerenciamento de resíduos sólidos urbanos eficaz e adequado do município.

Palavras-chave: Análise gravimétrica; Resíduos sólidos; Análise socioeconômica; Cooperativa de reciclagem. 


\section{INTRODUÇÃO}

A falta de infraestrutura para o descarte adequado de resíduos sólidos urbanos (RSU) ocasiona graves problemas ambientais. De acordo com o IBGE, no Brasil são produzidas 183 mil toneladas de RSU por dia (RESENDE et al., 2013).

Resíduos sólidos são definidos como lixos sólidos ou semissólidos, sendo resultados das atividades humanas e apresentam uma grande diversidade. Suas características físicas, químicas ou biológicas podem ser explicadas pela atividade geradora (ABNT, 2014).

No gerenciamento de RSU a análise gravimétrica, caracterização do resíduo, é fundamental para o seu tratamento e para uma disposição final eficaz, sem causar danos ao meio ambiente. A gravimetria dos RSUs pode ser benéfica tanto para a sociedade quanto para o meio ambiente, já que facilita o planejamento do órgão responsável de limpeza do município e a reciclagem de diversos resíduos (RESENDE et al., 2013).

Uma vez que não há dados atualizados da composição dos resíduos gerados em Poços de Caldas, este trabalho, baseado em Dutra, Oliveira e Pereira (2018), tem o objetivo de obtê-los para oferecer maior controle municipal, além de analisar o impacto da condição socioeconômica do gerador em determinados bairros da cidade.

\section{METODOLOGIA}

Neste trabalho foi feito a coleta de resíduos sólidos urbanos (RSU) em três setores de Poços de Caldas-MG. Os resíduos foram coletados, juntamente com funcionários da cooperativa Ação Reciclar, nos setores 4, 15 e 16, previamente selecionados. Uma vez que estes setores englobam 2 ou mais bairros, os setores foram divididos em zonas para facilitar a coleta de amostras em cada setor.

As coletas de resíduos na cidade são feitas todos os dias, então um grupo composto por três pessoas saíam antes do caminhão de coleta da prefeitura a fim de realizar a coleta de amostras dos resíduos. Primeiramente, o sistema de coleta consistiu em estabelecer um dia na semana e selecionar um setor para coletar os resíduos. Foi estabelecido que a amostra de cada zona para o respectivo setor na quantidade de um volume de 200 litros de resíduos, coletados em sacos plásticos, de forma aleatória.

Posteriormente, as amostras das coletas foram levadas para a cooperativa para serem triados. Antes do processo de triagem, cada saco plástico foi pesado. Em seguida, foi feito a separação dos resíduos para cada setor em: papel/papelão, plástico/PET, vidro, alumínio, matéria orgânica e lixo seco. Após a obtenção das informações de cada setor em relação a quantificação de RSU, foram usados os dados do censo do IBGE de 2010 para analisar a quantidade de RSU gerado por cada setor e sua respectiva renda domiciliar per capita.

\section{RESULTADOS E DISCUSSÃO}

Os setores censitários em Poços de Caldas são definidos pelo IBGE, obtidos no ano de 2010. A partir dos setores censitários estabelecidos pelo IBGE, utilizando o Google Earth ${ }^{\circledR}$ é possível correlacionar os setores de coleta analisados (FIGURA 1a e 1b).

Figura 1 - Setores de coleta (a) e respectivos setores censitários (b) em Poços de Caldas.

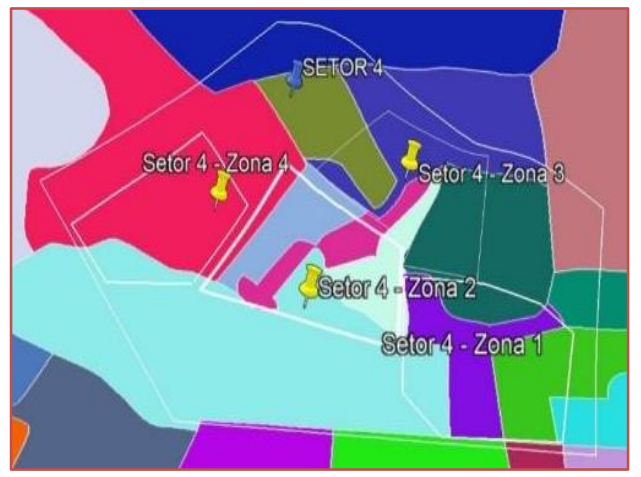

(a)

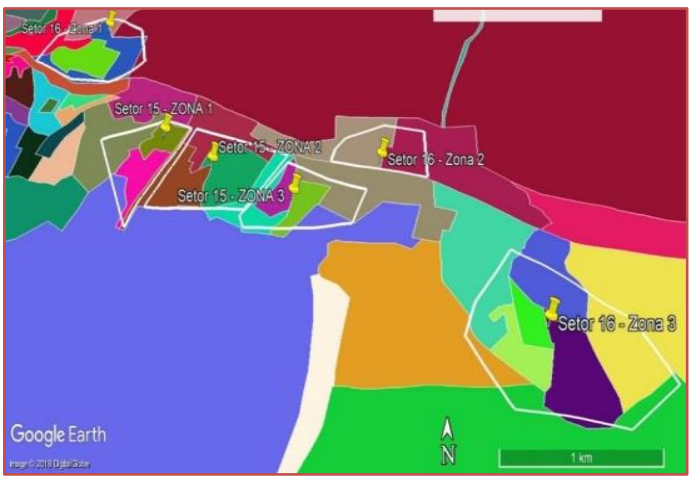

(b) 
Fonte: Adaptado de IBGE 2010.

Após a identificação dos setores de coleta (4, 15 e 16), fez-se a coleta e a análise gravimétrica dos RSUs, sendo utilizado valores médios de cada setor (TABELA 1).

Em todos os setores analisados, os resíduos classificados como matéria orgânica e lixo seco foram os mais representativos. Ou seja, há grande potencial para utilizar a compostagem como forma de tratamento. Após estes resíduos e os classificados como outros, destacam-se papel/papelão e plásticos seguidos pelo alumínio, em todos os setores, ou seja, favorece a reciclagem e, consequentemente, a cooperativa Ação Reciclar.

Tabela 1 - Análise gravimétrica dos RSUs em cada setor de coleta

\begin{tabular}{|l|c|c|c|}
\multicolumn{1}{|c|}{ Resíduo } & SETOR $4(\%)$ & SETOR 15 $(\%)$ & SETOR 16 $(\%)$ \\
\hline PAPEL/PAPELÃO & 2,09 & 3,34 & 2,00 \\
\hline PLÁSTICO/PET & 1,76 & 3,34 & 2,56 \\
\hline VIDRO & 1,74 & 1,06 & 0,71 \\
\hline ALUMÍNIO & 1,29 & 1,26 & 58,86 \\
\hline MATÉRIA ORGÂNICA & 43,00 & 48,15 & 26,25 \\
\hline LIXO SECO & 42,46 & 32,54 & 3,67 \\
\hline OUTROS & 7,66 & 10,31 & \\
\hline
\end{tabular}

Fonte: do autor.

Ao reclassificar os dados em dois grupos, recicláveis (papel/papelão, plástico/pet, vidro e alumínio) e nãorecicláveis (matéria orgânica e lixo seco), pode-se corroborar a importância dos tipos de tratamentos mencionados acima de acordo com cada setor.

Para estudar a influência socioeconômica na geração de resíduos em cada setor, dividimos em 3 classes salariais. Sendo estas, renda domiciliar per capita com até 1 salário mínimo, de 1 a 3 salários mínimos e maior que 3 salários mínimos. Uma vez que cada setor possui mais de uma zona, foi feita uma média salarial para cada setor (FIGURA 2).

Figura 2 - Percentual de renda domiciliar per capita.

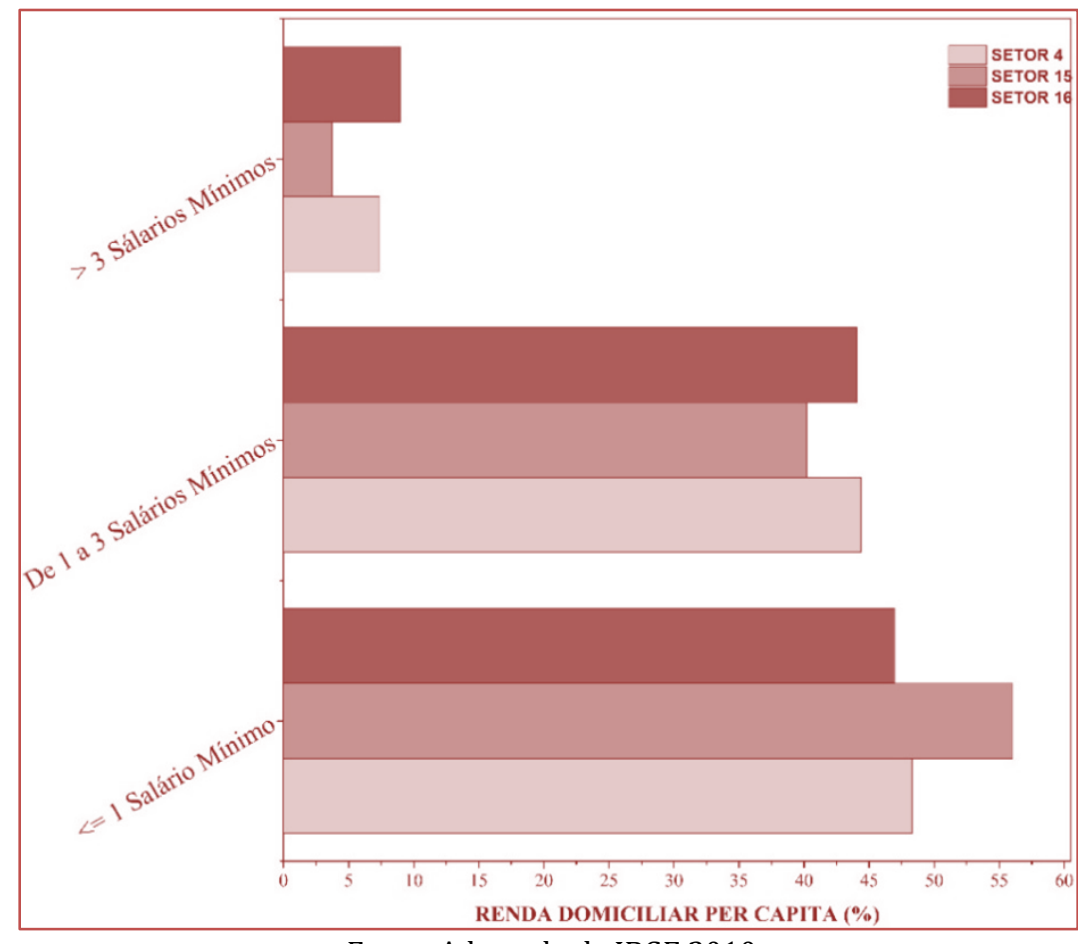

Fonte: Adaptado de IBGE 2010

A partir da Tabela 1 e da Figura 2, pode-se relacionar a geração de resíduos em cada setor com a condição socioeconômica. No qual o setor 16 , que apresentou a maior porcentagem de domicílios com renda per 
capita, superior a 3 salários mínimos, foi o setor que apresentou a maior média percentual de geração de papel/papelão, vidro e matéria orgânica. Ou seja, a maior renda pode aumentar o consumismo e gerar maior desperdício.

Já o setor 15, em que há a maior porcentagem de domicílios com renda até 1 salário mínimo, apresentou a maior média percentual de geração de plástico/pet. Enquanto o setor 4, que representa porcentagem média entre as faixas salariais foi a que mais gerou lixo seco e alumínio, comparando-se com os outros setores. Assim, nota-se o desafio da cooperativa Ação Reciclar pelo fato de haver pouca quantidade de recicláveis nestes setores.

\section{CONSIDERAÇÕES FINAIS}

Este trabalho foi fundamental para ter o conhecimento da composição dos resíduos sólidos urbanos (RSUs) em três setores de Poços de Caldas, além de relacioná-los com a condição socioeconômica dos habitantes. Verificou-se que os RSUs são compostos principalmente de matéria orgânica, sendo possível utilizar a compostagem como tratamento, e ainda por ter menor quantidade de recicláveis, torna-se um desafio para a cooperativa Ação Reciclar. Espera-se que outros trabalhos continuem a gravimetria dos RSUs e auxiliem no melhor controle e realização de projetos municipais.

\section{REFERÊNCIAS}

[1] ASSOCIAÇÃO BRASILEIRA DE NORMAS TÉCNICAS. NBR 10004: Resíduos sólidos - Classificação. 31.05.2004 ed. Rio de Janeiro, Rj - Brasil: Moderna, 2014. 71 p.

[2] DUTRA, I. C.; OLIVEIRA, J. H. F.; PEREIRA, L. H. Análises gravimétricas como ferramenta de gestão dos resíduos sólidos dos setores 4, 15 e 16 da cidade de Poços de Caldas - MG. 2018. 49 f. TCC (Graduação) - Curso de Bacharelado Interdisciplinar em Ciência e Tecnologia, UNIFAL, Poços de Caldas, 2019.

[3] INSTITUTO BRASILEIRO DE GEOGRAFIA E ESTATÍSTICA. Dados Censitários: Renda per capita domiciliar. 2010. Disponível em: <https://censo2010.ibge.gov.br/painel/>. Acesso em: 05 de maio de 2019.

[4] REZENDE, Jozrael Henriques et al. Composição gravimétrica e peso específico dos resíduos sólidos urbanos em Jaú (SP). Eng. Sanit. Ambient., Jaú (sp), Brasil, v. 1, n. 19, p.1-8, mar. 2013. 


\title{
Capítulo 3
}

\section{Avaliação da composição gravimétrica dos resíduos sólidos urbanos da cidade de Xangri-Lá}

\author{
Pâmela de Medeiros Engelmann \\ Gustavo Henrique Araújo dos Santos \\ Pedro Rocha da Rocha \\ Rogério Vescia Lourega \\ Jeane Estela Ayres de Lima
}

Resumo: 0 gerenciamento dos resíduos sólidos urbanos (RSUs) é um problema global em virtude da grande quantidade e heterogeneidade de resíduos que são produzidos em todo mundo. Afim de determinar a melhor maneira de gestão desses resíduos é de extrema importância que estudos sejam realizados para determinar suas características. Tanto a quantidade como a composição dos resíduos são parâmetros que auxiliam no planejamento, dimensionamento e escolha da tecnologia mais adequada de gestão. Assim esse trabalho visa determinar e avaliar a quantidade e as características gravimétricas dos resíduos sólidos urbanos produzidos na Cidade de Xangri-lá, Rio Grande do Sul. Um levantamento mensal da quantidade de resíduo produzido na cidade foi realizado ao longo do ano de 2018. Além disso, foram realizadas amostragem de resíduos para a determinação gravimétrica em duas estações do ano (inverno e verão). Os dados demonstram que há uma grande variação sazonal na quantidade de resíduos produzidos pela cidade, com um aumento significativo nos meses de janeiro e fevereiro. A análise da composição gravimétrica mostrou que os RSUs de Xangri-lá são compostos majoritariamente por resíduos orgânicos, principalmente em virtude da existência de coleta seletiva na cidade e também pelo fato desta fração ser mais pesada em relação as outras devido ao grande conteúdo de água presente.

Palavras-Chave: Resíduos Sólidos Urbanos, Gerenciamento de resíduos, Composição Gravimétrica. 


\section{INTRODUÇÃO}

Os resíduos sólidos urbanos (RSUs) são gerados pelo homem durante suas atividades diárias de forma contínua. 0 volume de resíduos gerados vem aumentado ao longo do tempo em todo o mundo e a tendência é que essas taxas continuem a crescer pelas próximas décadas (CZAJCZYŃSKA et al., 2017; DENG et al., 2017). Em 2012, 1,3 bilhão de toneladas de resíduos foram gerados pela população mundial e a perspectiva é que em 2025 a geração anual seja de 2,2 bilhões de toneladas, o que significa um crescimento de 1,2 para 1,42 kg diários por habitante em um curto intervalo de tempo (HOORNWEG E BHADA-TATA, 2012). Esse crescimento pode ser atribuído ao aumento da população mundial, nas últimas décadas, e aos hábitos atuais de consumo, onde as pessoas estão consumindo mais produtos para satisfazerem suas necessidades (SUTHAR; RAYAL; AHADA, 2016).

Os RSUs são compostos principalmente por papel, resíduos de alimento, resíduos orgânicos, resíduos de poda, plástico, metais, têxteis, vidro e outros resíduos que são gerados em domicílios residenciais, estabelecimentos comerciais e pequenas empresas de um município (GUPTA; YADAV; KUMAR, 2015; SHARHOLY et al., 2008). Em escala global, observa-se que a fração orgânica constitui a maior parcela dos RSUs, seguida pelas frações de papel, plástico, vidro e metal. A composição desses resíduos apresenta uma ampla variação entre cidades, estados e países, pois as diferenças culturais, o padrão de vida da população local e a extensão dos programas de reciclagem e reuso contribuem para tal característica (CZAJCZYŃSKA et al., 2017; SHONHIWA, 2013; TAHERYMOOSAVI et al., 2017). Assim, de um modo geral, as características dos RSUs pode ser utilizado como um indicador socioeconômico, visto que normalmente em locais com renda elevada os resíduos são compostos principalmente por papel, plástico e outros materiais inorgânicos, enquanto que em locais de baixa renda os RSUs são majoritariamente compostos por resíduos orgânicos (HOORNWEG; BHADA-TATA, 2012; CAMPOS, 2012; LIMA et al., 2018; MAYA et al., 2016; SHONHIWA, 2013).

0 gerenciamento, tratamento e a destinação final ambientalmente adequada dos RSUs são alguns dos maiores desafios do setor de saneamento básico da maioria das cidades ao redor do mundo, visto que uma má gestão pode provocar impactos na qualidade de vida da população e danos ao meio ambiente (contaminação do ar, da água e do solo) (CZAJCZYŃSKA et al., 2017). O custo muitas vezes elevado de gerenciamento desses resíduos faz com que muitas cidades mundiais, assim como brasileiras, descartem seus resíduos diretamente em aterros sanitários e lixões sem passarem por etapas de reciclagem, reuso e aproveitamento energético. A disposição de resíduos no solo em aterros sanitário, apesar de ser considerada ambientalmente correta, é vista como a última opção dentre a hierarquia dos resíduos, pois a gestão inadequada dessas áreas pode acarretar em impactos ambientais ao solo, aos recursos hídricos (vazamento de lixiviado) e ao ar (emissões de metano $\left(\mathrm{CH}_{4}\right)$ e outros gases de efeito estufa) (COUTO et al., 2017; GENUINO; DE LUNA; CAPAREDA, 2018; RAMOS et al., 2018). Outro problema comumente encontrado para aplicação dessa técnica é demanda por grandes áreas disponíveis para a eliminação dos resíduos em virtude da escassez de áreas para deposição, que é acentuada especialmente nos grandes centros urbanos (COUTO; SILVA; ROUBOA, 2016a, 2016b; ROKNI, 2017; YOU et al., 2016).

Assim, em virtude dos problemas encontrados na disposição de resíduos em aterros sanitários citados acima, da conscientização pública crescente sobre as questões ambientais e do aumento da demanda de energia proveniente de fontes renováveis observa-se gradativamente a expansão e o interesse por soluções modernas e eficientes para o gerenciamento dos RSUs (GENUINO; DE LUNA; CAPAREDA, 2018; SANLISOY; CARPINLIOGLU, 2017). Sistemas modernos e eficientes normalmente englobam etapas de redução da quantidade de resíduo gerado, reuso, reciclagem, tratamento para produção de energia e, por fim, a disposição em aterros sanitários.

Uma etapa importante desses sistemas de gestão ambientalmente adequado é a implantação de processos de tratamento de resíduo que visem a produção de energia, conhecidos como WTE (do inglês waste-toenergy). Essas tecnologias, quando empregadas em um sistema integrado de gerenciamento de RSUs, desempenham funções importantes, tais como: reduzir o volume de resíduos descartados em aterros sanitários, recuperar a energia existente nos resíduos, recuperar minerais e produtos químicos que podem ser reutilizados ou reciclados e ainda, destruir vários contaminantes (WHITICAR; RALPH, 2011). Além disso, essas tecnologias podem ser importantes no fornecimento de energia renovável ao planeta, principalmente considerando a crescente demanda global por energia e as perspectivas de esgotamento das fontes de combustíveis fósseis no mundo (OUDA; RAZA, 2014; SHEHZAD; BASHIR; SETHUPATHI, 2016; YOU et al., 2016).

0 tratamento dos RSUs em plantas de WTE é realizado principalmente por processos termoquímicos (incineração, pirólise e gaseificação) e bioquímicos (digestão anaeróbia e aterro com captura de gás) 
(BEYENE; WERKNEH; AMBAYE, 2018; ISLAM, 2018; KUMAR; SAMADDER, 2017). Os processos termoquímicos convertem resíduos em energia através de calor (temperatura elevada) e reações químicas, enquanto que os processos bioquímicos utilizam bactérias, outros micro-organismos e enzimas para decompor os resíduos em substâncias mais simples (BEYENE; WERKNEH; AMBAYE, 2018; DHAR; KUMAR; KUMAR, 2017). Entre os processos termoquímicos, a grande diferença entre as técnicas está na quantidade de oxigênio $\left(\mathrm{O}_{2}\right)$ utilizado na queima dos resíduos. No processo de incineração ocorre a oxidação completa dos resíduos, pois há $\mathrm{O}_{2}$ em excesso no meio, já na gaseificação o $\mathrm{O}_{2}$ no processo é limitado e a combustão completa não ocorre, e por outro lado, o processo de pirólise ocorre na ausência de $\mathrm{O}_{2}$ (WILLIAMS, 2005). Nos processos bioquímicos de conversão de resíduos, as duas técnicas são semelhantes no que diz respeito ao processo de conversão e a diferença está que a digestão anaeróbia ocorre em um reator fechado com parâmetros de processo controlados e otimizados para a produção de biogás, enquanto que nos aterros sanitários, esse processo ocorre de forma natural e, consequentemente, em um tempo mais longo (TANIGAWA, 2017; WILLIAMS, 2005).

Como mostrado acima existem algumas opções para a produção de energia a partir de resíduos, então a escolha da tecnologia mais adequada dependerá de fatores como: a composição dos resíduos, o custo do processo, localização geográfica das plantas e também da eficiência requerida (NIZAMIA et al., 2015). Ou seja, todas as opções apresentam algumas vantagens e desvantagens e a escolha da tecnologia mais adequada para cada realidade está vinculada à critérios ambientais, econômicos, políticos, sociais e técnicos (ANTONOPOULOS et al., 2014). Dentre os critérios técnicos, o conhecimento das características quantitativas (taxa de geração por habitante, $\mathrm{kg} / \mathrm{habitante}$ dia) e qualitativas (propriedades físicas, químicas e microbiológicas) são de fundamental importância para auxiliar nessa escolha (ABDEL-SHAFY; MANSOUR, 2018). Como exemplo pode ser citado a determinação da taxa de geração por habitante (kg/habitante.dia) que é essencial no planejamento de todo o sistema de gerenciamento do lixo, principalmente no dimensionamento de instalações e equipamentos (CEMPRE, 2018). Outro exemplo, é a obtenção de dados precisos e confiáveis sobre a composição dos resíduos (porcentagem de cada fração dos RSUs), pois essas informações normalmente são o ponto de partida para o planejamento da gestão de resíduos e para a aplicação de processos de produção de energia (ABDEL-SHAFY; MANSOUR, 2018). Desta forma, esse trabalho tem por objetivo determinar e avaliar a quantidade e as características gravimétricas dos resíduos sólidos urbanos produzidos na Cidade de Xangri-lá, Rio Grande do Sul.

\section{METODOLOGIA}

A cidade de Xangri-lá é um município do estado do Rio Grande do Sul que está localizada no litoral norte. Os resíduos sólidos urbanos produzidos na cidade são coletados por caminhões da prefeitura e tem como destino final o aterro sanitário da cidade de Capão da Canoa, cidade vizinha a Xangri-lá. Além da coleta convencional, o município realiza a coleta dos resíduos recicláveis através da coleta seletiva. Esses resíduos são transportados até a Associação dos Agentes Econômicos Ecológicos de Capão da Canoa, localizada na mesma área do aterro sanitário da cidade de Capão da Canoa. A Associação é a responsável pela triagem, separação e venda desses resíduos recicláveis.

Por estar localizada em uma região litorânea, a cidade de Xangri-lá recebe uma grande quantidade de turistas nos meses de alta temporada (dezembro, janeiro, fevereiro e março). Estima-se que a população da cidade nesses meses chegue a 100.000 mil habitantes, o que significa um aumento de aproximadamente 6,5 vezes no número de habitantes em relação aos outros meses do ano, que de acordo com a última estimativa do Instituto Brasileiro de Geografia e Estatística (IBGE) é de 16.025 mil habitantes (IBGE, 2019). Como consequência, há também um aumento considerável na quantidade de resíduos sólidos urbano gerados. Então, afim de avaliar essa variação entre os meses de alta e baixa temporada foi realizado um levantamento da quantidade mensal de resíduos produzidos pela cidade ao longo do ano de 2018. Para tal, os dados dispostos nos relatórios elaborados mensalmente pela prefeitura municipal de Capão da Canoa, responsável pelo aterro onde os resíduos de Xangri-lá são dispostos, foram compilados e analisados.

Além da variação na quantidade de resíduos gerados no decorrer do ano, esse trabalho buscou verificar se a flutuação na densidade populacional exerce alguma influência na composição desses resíduos. Desta forma, a amostragem dos resíduos da cidade de Xangri-lá foi realizada em duas estações do ano: inverno e verão. Nos dias de coleta, os resíduos foram dispostos na forma de monte, em cima de uma lona plástica a fim de evitar contaminação dos mesmos. Em seguida, 5 toneis de 200 litros foram preenchidos com amostras provenientes de cinco pontos (topo e as quatro laterais) da pilha de resíduos. Na sequência, o conteúdo dos 5 tonéis foi despejado sobre outra lona plástica, onde os sacos foram abertos e os resíduos 
misturados com o auxílio de pás e enxadas. Por fim, foram realizados dois quarteamento (com descarte vis-à-vis), com a finalidade de reduzir o tamanho da amostra. A Figura 1 apresenta de forma resumida o procedimento detalhado acima que foi baseado na Norma Brasileira (ABNT) 10007/2004.

Figura 1. Descrição resumida do processo de amostragem.

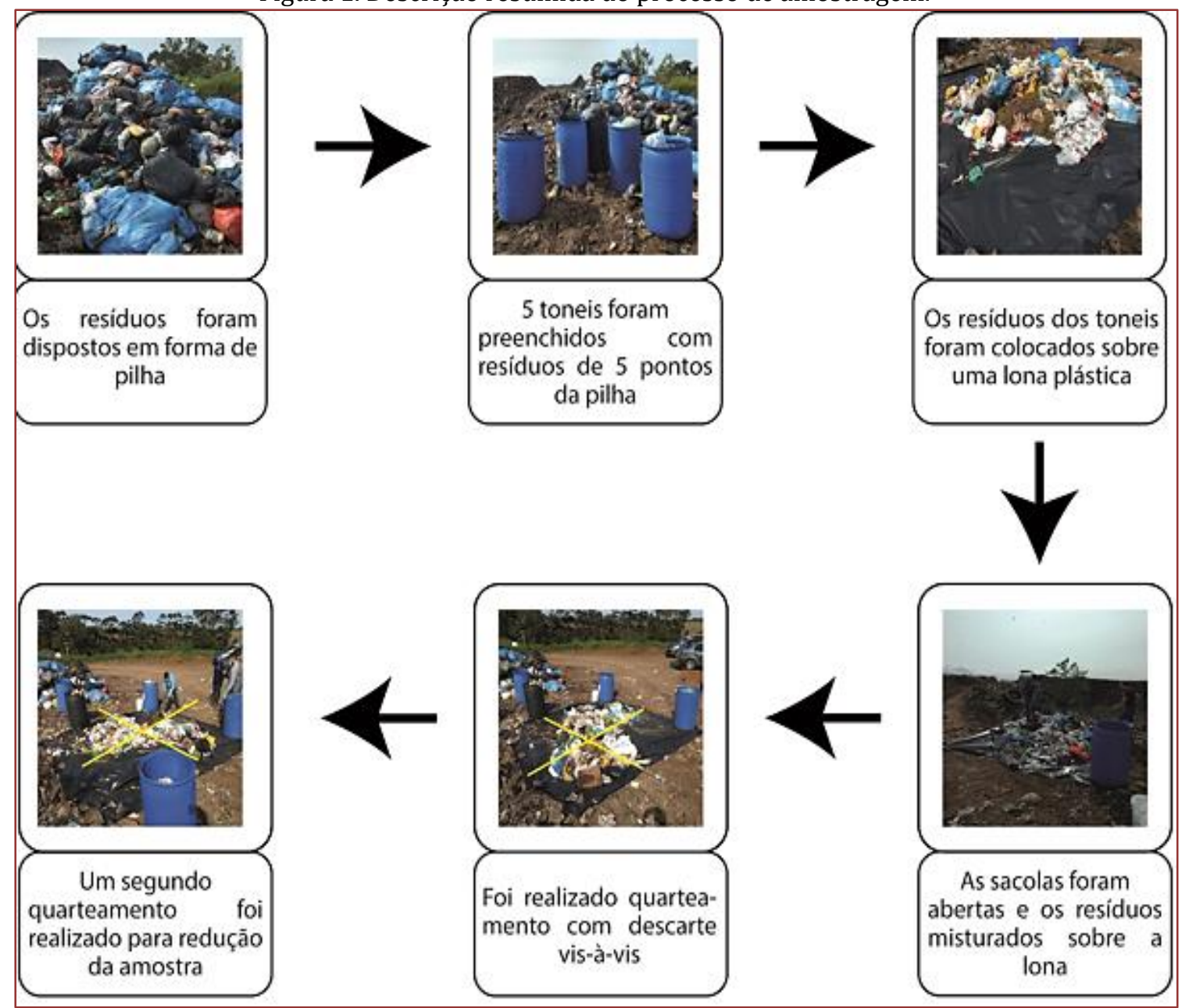

Os resíduos resultantes do processo de quarteamento foram separados manualmente nos seguintes componentes: matéria orgânica, plástico, vidro, papel e papelão, alumínio, metais, eletrônicos, pano, trapo, couro e borracha, madeira e isopor. Após o processo de separação as frações foram pesadas separadamente com o auxílio de uma balança portátil, para posterior determinação da porcentagem de cada componente na fração total.

\section{RESULTADOS}

Através dos dados coletados nos relatórios mensais elaborados pela administração do aterro sanitário de Capão da Canoa foi possível construir o gráfico apresentado na Figura 2. 0 gráfico apresenta a quantidade de resíduo gerado pela cidade de Xangri-lá no decorrer do ano de 2018, recolhido na coleta regular e seletiva. Os dados demonstram que há uma grande variação sazonal na quantidade de resíduos produzidos pela cidade, com um aumento significativo nos meses de janeiro e fevereiro. Observa-se também uma baixa significativa nos meses de maio, junho e julho com uma tendência de crescimento a partido mês de agosto. 
Figura 2. Gráfico da quantidade mensal de resíduos produzidos na cidade de Xangri-lá.

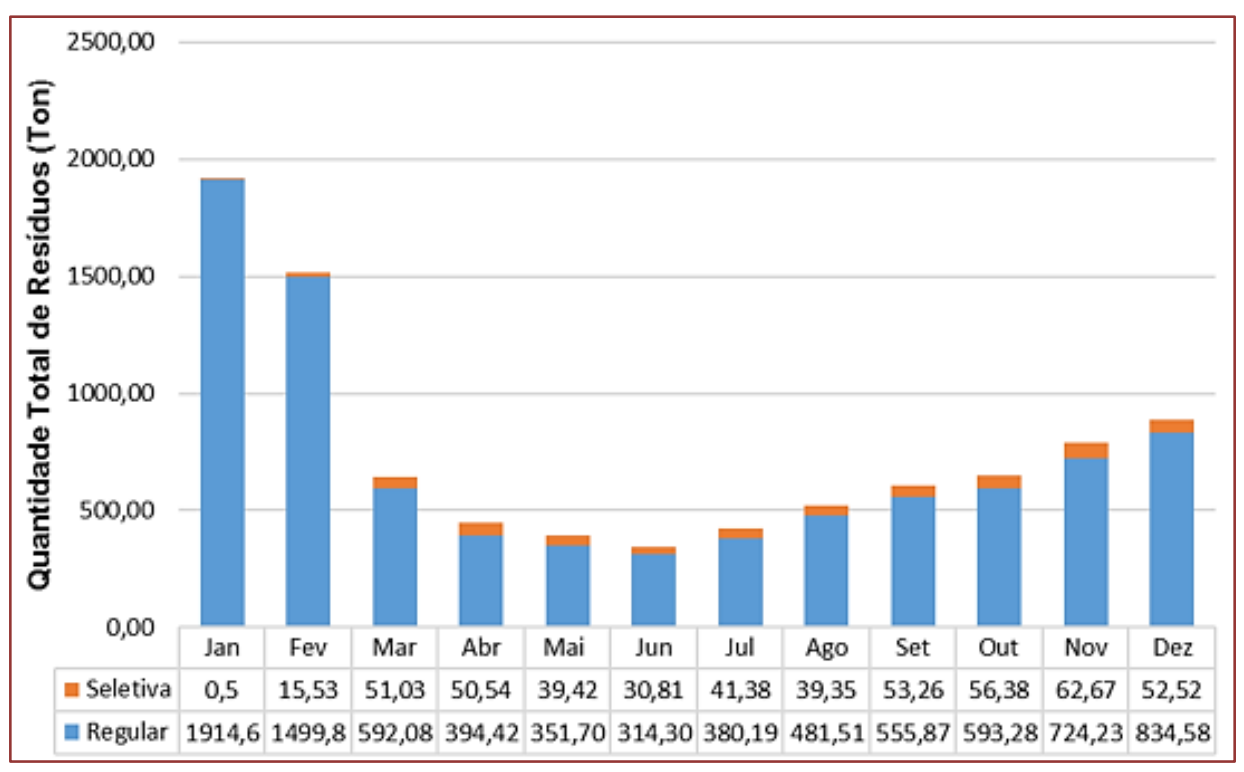

Fonte: Autor do Trabalho.

Analisando os dados acima mencionados também é possível notar que uma quantidade pequena da fração total é destinada para a coleta seletiva, resultando com que a maioria dos resíduos seja descartado no aterro sanitário. Assim, nota-se a necessidade de realizar um processo de conscientização da população da cidade sobre a importância de realizar a separação dos resíduos e de esclarecimentos sobre os tipos de resíduos que devem ser encaminhados para cada coleta (convencional e seletiva). Essas medidas poderão auxiliar na redução da quantidade de resíduo que é descartado no aterro sanitário, reduzir os impactos ambientais da prática de aterramento e diminuir os custos da cidade com o gerenciamento dos resíduos.

A composição gravimétrica dos resíduos da cidade de Xangri-lá pode ser visualizada Tabela 1. Os resultados mostram que em média $75 \%$ dos resíduos (em peso) destinados ao aterro sanitário são constituídos por matéria orgânica. 0 percentual elevado de matéria orgânica é consequência da presença da coleta seletiva na cidade, que retira uma parcela dos resíduos recicláveis da coleta convencional. Além disso, de um modo geral os resíduos orgânicos apresentam como principal característica uma grande quantidade de água na sua composição, o que torna essa fração dos RSUs mais pesada que resíduos como plásticos e papeis.

Tabela 1. Resultado da composição gravimétrica dos resíduos de Xangri-lá no Inverno.

\begin{tabular}{|c|c|c|}
\hline Componente & Inverno (\%) & Verão (\%) \\
\hline Matéria Orgânica & 77,34 & 76,06 \\
\hline Plástico & 9,36 & 10,64 \\
\hline Vidro & 3,21 & 4,58 \\
\hline Papel e Papelão & 6,00 & 4,70 \\
\hline Alumínio & 0,55 & 0,58 \\
\hline Metais & 0,76 & 0,68 \\
\hline Tecidos & 2,36 & 1,54 \\
\hline Madeira & 0,00 & 0,39 \\
\hline Isopor & 0,41 & 0,86 \\
\hline Total & 100,00 & 100,00 \\
\hline
\end{tabular}

Apesar da análise gravimétrica mostra que a fração orgânica é o componente majoritário nos resíduos da cidade de Xangri-lá, visualmente observa-se a presença de muitos materiais recicláveis, como latinhas de alumínio e garrafas pets, que são materiais muito leves, mas que ocupam um grande volume. No entanto, tendo em vista que a cidade dispõe de coleta seletiva, esses materiais deveriam ser separados pela população e serem destinados corretamente. Sendo assim, a análise visual dos resíduos vai de encontro com os dados apresentados no item anterior, pois a cidade destina uma quantidade muito pequena do montante total dos seus resíduos para a coleta seletiva. Essa análise comprova a necessidade de 
conscientização da população, citada anteriormente, para evitar que esse tipo de material que pode ser reciclado seja descartado em aterros sanitários.

\section{CONCLUSÕES}

Observa-se que apesar da cidade possuir coleta seletiva, uma grande quantidade de resíduos recicláveis é destinada ao aterro sanitário. Assim verifica-se a necessidade de um processo de conscientização da população para evitar que esse tipo de material que pode ser reciclado acabe sendo disposto no aterro sanitário. Além das questões ambientais, a separação correta dos resíduos recicláveis apresenta um papel social, visto que várias pessoas dependem da venda destes materiais para sobreviver. Então, quanto mais resíduos forem destinados à coleta seletiva, maior será a renda desta parcela da população da cidade e consequentemente melhor será a qualidade de vida dessas pessoas.

\section{REFERÊNCIAS}

[1] Abdel-Shafy, H. I.; Mansour, M. S. M. Solid waste issue: Sources, composition, disposal, recycling, and valorization. Egyptian Journal of Petroleum, v. 27, n. 4, p. 1275-1290, 2018.

[2] Abnt. Amostragem de resíduos sólidos. p. 25, 2004.

[3] Antonopoulos, I. S. et al. Ranking municipal solid waste treatment alternatives considering sustainability criteria using the analytical hierarchical process tool. Resources, Conservation and Recycling, v. 86, p. 149-159, 2014.

[4] Beyene, H. D.; Werkneh, A. A.; Ambaye, T. G. Current updates on waste to energy (WtE) technologies: a review. Renewable Energy Focus, v. 24, p. 1-11, 2018.

[5] Campos, H. K. T. Renda e evolução da geração per capita de resíduos sólidos no Brasil. Engenharia Sanitaria E Ambiental, v. 17, n. 2, p. 171-180, 2012.

[6] Cempre. Lixo municipal: Manual de gerenciamento integrado. São Paulo: CEMPRE.

[7] Couto, N. et al. 2nd law analysis of Portuguese municipal solid waste gasification using $\mathrm{CO}_{2} /$ air mixtures. Journal of CO2 Utilization, v. 20, p. 347-356, 2017.

[8] Couto, N. D.; Silva, V. B.; Rouboa, A. Thermodynamic Evaluation of Portuguese municipal solid waste gasi fi cation. Journal of Cleaner Production, v. 139, p. 622-635, $2016 \mathrm{a}$.

[9] Couto, N. D.; Silva, V. B.; Rouboa, A. Assessment on steam gasification of municipal solid waste against biomass substrates. Energy Conversion and Management, v. 124, p. 92-103, 2016b.

[10] Czajczyńska, D. et al. Potential of pyrolysis processes in the waste management sector. Thermal Science and Engineering Progress, v. 3, p. 171-197, 2017.

[11] Deng, N. et al. Simulation analysis and ternary diagram of municipal solid waste pyrolysis and gasification based on the equilibrium model. Bioresource Technology, v. 235, p. 371-379, 2017.

[12] Dhar, H.; Kumar, S.; Kumar, R. A review on organic waste to energy systems in India. Bioresource Technology, v. 245, p. 1229-1237, 2017.

[13] Genuino, D. A. D.; de Luna, M. D. G.; Capareda, S. C. Improving the surface properties of municipal solid wastederived pyrolysis biochar by chemical and thermal activation: Optimization of process parameters and environmental application. Waste Management, v. 72, p. 255-264, 2018.

[14] Gupta, N.; Yadav, K. K.; Kumar, V. Review on scenario of municipal solid waste management in India. Journal of Environmental Sciences, v. 37, n. 3, p. 561-565, 2015.

[15] Hoornweg, D.; Bhada-Tata, P. What a Waste: A Global Review of Solid Waste Management. Washington: Word Bank, 2012.

[16] Ibge. Panorâma: Xangri-lá. Instituto Brasileiro de Geografia e Geoestatistica., 2019.

[17] Islam, K. M. N. Municipal solid waste to energy generation: An approach for enhancing climate co-benefits in the urban areas of Bangladesh. Renewable and Sustainable Energy Reviews, v. 81, p. 2472-2486, 2018.

[18] Kumar, A.; Samadder, S. R. A review on technological options of waste to energy for effective management of municipal solid waste. Waste Management, v. 69, p. 407-422, 2017.

[19] Lima, J. Z. et al. Assessment of the use of organic composts derived from municipal solid waste for the adsorption of $\mathrm{Pb}, \mathrm{Zn}$ and Cd. Journal of Environmental Management, v. 226, n. July, p. 386-399, 2018. 
[20] Maya, D. M. Y. et al. Gasification of Municipal Solid Waste for Power Generation in Brazil, a Review of Available Technologies and Their Environmental Benefits. Brazilian Journal of Chemical Engineering, v. 10, p. 249255,2016

[21] Nizamia, A.-S. et al. An Argument for Developing Waste-to-Energy Technologies in Saudi Arabia. Chemical Engineering Transactions, v. 45, p. 337-342, 2015.

[22] Ouda, O. K. M.; Raza, S. A. Waste-to-Energy: Solution for Municipal Solid Waste Challenges - Global Perspective. International Symposium on Technology Management and Emerging. Anais...Bandung: 2014

[23] Ramos, A. et al. Co-gasification and recent developments on waste-to-energy conversion: A review. Renewable and Sustainable Energy Reviews, v. 81, p. 380-398, 2018.

[24] Rokni, M. Design and analysis of a waste gasification energy system with solid oxide fuel cells and absorption chillers. International Journal of Hydrogen Energy, p. 1-17, 2017.

[25] Sanlisoy, A.; Carpinlioglu, M. O. A review on plasma gasification for solid waste disposal. International Journal of Hydrogen Energy, v. 42, p. 1361-1365, 2017.

[26] Sharholy, M. et al. Municipal solid waste management in Indian cities - A review. Waste Management, v. 28, p. 459-467, 2008.

[27] Shehzad, A.; Bashir, M. J. K.; Sethupathi, S. System analysis for synthesis gas (syngas) production in Pakistan from municipal solid waste gasification using a circulating fluidized bed gasifier. Renewable and Sustainable Energy Reviews, v. 60, p. 1302-1311, 2016.

[28] Shonhiwa, C. An assessment of biomass residue sustainably available for thermochemical conversion to energy in Zimbabwe. Biomass and Bioenergy, v. 52, p. 131-138, 2013.

[29] Suthar, S.; Rayal, P.; Ahada, C. P. S. Role of different stakeholders in trading of reusable/recyclable urban solid waste materials: A case study. Sustainable Cities and Society, v. 22, p. 104-115, 2016.

[30] Taherymoosavi, S. et al. Characterization of organic compounds in biochars derived from municipal solid waste. Waste Management, v. 67, p. 131-142, 2017.

[31] Tanigawa, S. Biogas: Converting Waste to Energy. Disponível em: <http://www.eesi.org/papers/view/factsheet-biogasconverting-waste-to-energy>. Acesso em: 9 maio. 2018.

[32] Whiticar, D. M.; Ralph, J. Waste to Energy: A Technical Review of Municipal Solid Waste Thermal Treatment Practices - Final Report. Burnaby: Stantec Consulting Ltd, 2011.

[33] Williams, P. T. Waste Treatment and Disposal. 2nd. ed. Chichester: John Wiley \& Sons Ltd, 2005.

[34] You, S. et al. Comparison of the co-gasification of sewage sludge and food wastes and cost-benefit analysis of gasification- and incineration-based waste treatment schemes. Bioresource Technology, v. 218, p. 595-605, 2016. 


\section{Capítulo 4}

\section{Avaliação do impacto da coleta seletiva na destinação final dos resíduos sólidos urbanos na Cidade de Itabira-MG}

Geraldo Ramos Madeira

Adenilson Evangelista Botelho

Eliane Maria Vieira

Resumo: A grande geração e destinação final inadequada de resíduos sólidos trazem consequências adversas ao meio ambiente, como por exemplo, a contaminação de mananciais superficiais e subterrâneos, que exigem a utilização de recursos para sua remediação e recuperação. Nesse contexto, a coleta seletiva e a reciclagem de materiais apresentam-se como importantes soluções para este problema. Assim, esse trabalho tem como objetivo discutir a importância da coleta seletiva de resíduos, analisando o caso da cidade de Itabira/MG. A pesquisa foi desenvolvida por meio da análise de notas fiscais e outros documentos com as informações referentes aos processos de comercialização de resíduos sólidos, oriundos da coleta seletiva da cidade Itabira-MG, fornecidas pela Empresa de Desenvolvimento de Itabira Ltda (ITAURB), referentes ao triênio 20162018. No período analisado identificou-se que a ITAURB comercializou, via notas fiscais de venda, mais de 3.600.000,0 quilos de resíduos que foram separados no seu centro de triagem. Ainda podem ser adicionados a esse valor mais de 39.000 itens tais como pet, garrafas, pneus e eletrônicos que foram comercializados de forma individualizada. Os resultados alcançados demonstram como a coleta seletiva de resíduos vem proporcionando importantes ganhos ambientais para a cidade de Itabira/MG, uma vez que, em apenas 03 anos, quase 4 mil toneladas de materiais foram reinseridas no ciclo produtivo e deixaram de ser encaminhados para o aterro sanitário, aumentando assim a sua vida útil.

Palavras-chave: Comercialização; resíduos; reciclagem. 


\section{INTRODUÇÃO}

0 resíduo urbano, popularmente tratado como lixo, passou a ser um dos grandes problemas que ameaçam a saúde humana e a vida no planeta, pois além de poluir o solo, a água e o ar, também atrai animais que veiculam doenças. Para Dias (2004), a questão do "lixo" gerado nas cidades é, sem dúvida, um dos grandes problemas na maioria dos municípios brasileiros. É preciso refletir que o resíduo, após ser recolhido pelos coletores e catadores, ele não desaparece, apenas é levado para um outro local, onde deverá ter a destinação adequada.

Dentre as diversas formas de destinação final de resíduos sólidos utilizadas no Brasil pode-se destacar a disposição em lixões, em aterros controlados ou aterros sanitários, a incineração e a triagem para reciclagem, sendo esta última alternativa a mais ambientalmente correta, uma vez que além de diminuir a quantidade de resíduos descartados ainda reintroduz parte dos materiais nos ciclos produtivos diminuindo a pressão sobre as fontes de matérias primas e sobre o meio ambiente.

Sendo a triagem um processo caro e extremamente dependente de mão de obra, seu sucesso é, consideravelmente, aumentado quando o sistema de gerenciamento de resíduos sólidos conta com a coleta seletiva. No Brasil este tipo de coleta existe, pelo menos, desde a década de 1950, quando foi difundida pelo surgimento de catadores conhecidos como "garrafeiros" e "papeleiros" que recolhiam os materiais pela cidade para serem comercializados junto às recicladoras. Eigenheer e Ferreira (2015), descrevem que a primeira experiência sistemática e documentada no país só foi implantada em 1985, no bairro de São Francisco em Niterói (RJ).

Em Minas Gerais, o primeiro programa de coleta seletiva implantado foi o da cidade de Itabira, em 1991, sob a gestão da Empresa de Desenvolvimento de Itabira Ltda - ITAURB. Inicialmente a coleta seletiva abrangeu uma área piloto com 5 bairros centrais da cidade, atendendo 9.768 pessoas, equivalente à $9,8 \%$ da população. Posteriormente o programa foi evoluindo lentamente até atingir todos os bairros da cidade, em abril de 2002 (inclusive os distritos).

Na cidade, a coleta seletiva se dá da seguinte forma: os habitantes da cidade separam seus resíduos em recicláveis e não recicláveis que posteriormente são recolhidos porta a porta pela ITAURB, separadamente. Portanto, o seu sucesso está diretamente associado aos investimentos em programas de educação ambiental que visam a sensibilização e conscientização da população. Bringhenti e Günther (2011), destacam que, quanto maior for a participação voluntária em programas de coleta seletiva, melhor será o resultado alcançado, obtendo também um menor custo de administração do programa.

No processo, o material seco (papéis, vidros, metais, plásticos, etc.) é separado e enfardado no Centro de Triagem e comercializado diretamente com as indústrias recicladoras situadas num raio médio de 200 quilômetros da cidade, pois Itabira não possui nenhuma indústria de reciclagem.

Assim, o presente trabalho teve como objetivo avaliar a contribuição ambiental do sistema da coleta seletiva da cidade de Itabira-MG, considerando o volume de material reciclável separado no centro de triagem de resíduos sólidos da cidade nos anos de 2016, 2017 e 2018.

\section{METODOLOGIA}

A quantificação do material reciclável separado foi feita pela análise das notas fiscais de saída do Centro de Triagem de Resíduos Sólidos e Educação Ambiental da Empresa de Desenvolvimento de Itabira Ltda ITAURB, na cidade de Itabira-MG para os anos de 2016, 2017 e 2018.

De acordo com a descrição do tipo de material comercializado, presente nas notas fiscais, os itens foram divididos em duas classes conforme abaixo:

1 - Materiais comercializados individualizados (unidade): garrafas e frascos de vidro, PETs, pneus inservíveis, sucata eletrônica, vasilhames de plástico 1L, 2L e 5L.

2 - Materiais comercializados não individualizados (quilos): alumínio, sucata ferrosa, vidro triturado, isopor, papel e plástico.

De posse da informação da quantidade e do volume de materiais comercializados foram avaliados os benefícios ambientais da coleta seletiva e do processo de triagem de resíduos da cidade de Itabira-MG. 


\section{RESULTADOS E DISCUSSÃO}

Dos materiais individualizados foi possível identificar que, no triênio de 2016-2018, um total de 39.317 itens deixaram de ser encaminhados para o aterro sanitário da cidade, conforme quadro 1.

Quadro 1 - Quantidade de materiais comercializados individualizados

\begin{tabular}{|c|c|c|c|c|}
\hline Tipo de resíduo & Unidade & 2016 & 2017 & 2018 \\
\hline Garrafas e frascos de vidro & peça & 356 & & 3.540 \\
\hline PET & peça & 10.700 & 4.241 & 1.850 \\
\hline Pneus inservíveis & peça & & 5.355 & 4.014 \\
\hline Sucata de eletrônico & peça & 5.000 & 2.000 & 2.000 \\
\hline Vasilhame de plástico 1L, 5L e 20L & peça & 261 & & \\
\hline Total & & 16.317 & 11.596 & 11.404 \\
\hline
\end{tabular}

Em relação aos itens comercializados não individualizados, foi possível identificar que no período em estudo um total de $3.689 .530,2 \mathrm{~kg}$ de materiais foram reintroduzidos nos sistemas produtivos conforme quadro 2. Tal processo consiste no enfardamento dos materiais através de prensas hidráulicas, para a posterior comercialização com as indústrias recicladoras.

Quadro 2 - Quantidade de materiais comercializados não individualizados

\begin{tabular}{|l|c|c|c|c|}
\multicolumn{4}{c|}{ Unidade } & \multicolumn{2}{c|}{2016} & 2017 & 2018 \\
\hline Alumínio & $\mathrm{kg}$ & $5.678,00$ & $2.008,10$ & $4.199,80$ \\
\hline Sucata ferrosa & $\mathrm{kg}$ & $80.991,00$ & $51.035,00$ & $49.660,00$ \\
\hline Vidro triturado & $\mathrm{kg}$ & $196.552,00$ & $195.360,00$ & $175.770,00$ \\
\hline Isopor & $\mathrm{kg}$ & $2.903,00$ & $3.474,00$ & $4.961,00$ \\
\hline Papel (diversos) & $\mathrm{kg}$ & $772.540,00$ & $687.159,90$ & $626.472,90$ \\
\hline Plásticos & $\mathrm{kg}$ & $275.917,20$ & $283.429,60$ & $271.481,70$ \\
\hline \multicolumn{1}{|c|}{ Total } & $\mathrm{Kg}$ & $1.334 .581,20$ & $1.222 .466,60$ & $1.132 .482,40$ \\
\hline
\end{tabular}

Cabe salientar que, durante a execução dos trabalhos, em entrevista informais junto aos funcionários da coleta e da unidade de triagem e separação de resíduos, foi possível identificar que grande parte do material reciclável colocado na via pública pelos cidadãos, nos dias da coleta, é recolhido por catadores autônomos que passam antes dos caminhões da ITAURB, e retiram apenas os materiais de maior valor econômico e de fácil comercialização.

Outras destinações que não foram possíveis de quantificar pelo estudo, tratam-se de materiais como PET, frascos de perfumes, litros e garrafas de vidro, eletrônicos e pneus inservíveis que são doados na sede da unidade de triagem sem emissão de notas fiscais. Esses materiais normalmente são utilizados em trabalhos de artesanatos, envasamento de sabões e cachaças artesanais e construção de muros de arrimos.

\section{CONCLUSÕES}

Os resultados alcançados demonstram o enorme potencial da coleta seletiva e reciclagem de materiais como instrumentos de preservação do meio ambiente. Foi possível concluir com o trabalho que o processo de coleta seletiva produz um enorme ganho ambiental para a cidade uma vez que, considerando somente os itens comercializados após a triagem, mais de 3 mil toneladas de materiais deixaram de ser encaminhados para o aterro sanitário, aumentando assim a sua vida útil. 
Conclui-se também que para uma quantificação mais precisa da quantidade de materiais reaproveitados com o auxílio da coleta seletiva da cidade, na continuidade do presente estudo, deverão ser desenvolvidas estratégias para quantificação dos materiais recolhidos pelos catadores autônomos e também dos materiais doados na sede da empresa.

\section{AGRADECIMENTOS}

Os autores agradecem a Universidade Federal de Itajubá - UNIFEI, a Agência Nacional de Recursos Hídricos - ANA, a Coordenação de Aperfeiçoamento de Pessoal de Nível Superior - CAPES e ao Programa de Mestrado Profissional em Rede Nacional em Gestão e Regulação dos Recursos Hídricos - ProfÁgua, projeto CAPES/ANA AUXPE no 2717/2015.

\section{REFERÊNCIAS}

[1] Bringhenti, J.R. \& Gunther, W.M.R. Participação social em programas de coleta seletiva de resíduos sólidos urbanos. Eng Sanit Ambient | v.16 n.4 | out/dez 2011 | 421-430. Disponível em: http://www.scielo.br/pdf/esa/v16n4/a14v16n4.pdf. Acesso em 12 mai. 2019.

[2] Dias, Genebaldo Dias. Educação Ambiental: Princípios e Práticas. 9a Edição. São Paulo: Gaia, 2004.

[3] Eigenheer, E.M.; Ferreira, J.A. Três décadas de coleta seletiva em São Francisco (Niterói/RJ): lições e perspectivas. Rio de Janeiro. Eng Sanit Ambient. v.20 n.4. out/dez 2015. 677-684. Disponível em: http://www.scielo.br/pdf/esa/v20n4/1413-4152-esa-20-04-00677.pdf. Acesso em 09 mai. 2019. 


\section{Capítulo 5}

\section{Avaliação do ciclo de vida de cenários de gestão dos resíduos sólidos orgânicos no Distrito Federal}

\section{Allan Luís Augusto Redes de Oliveira Armando de Azevedo Caldeira Pires}

Resumo: Este artigo tem o objetivo de avaliar os potenciais impactos ambientais de diferentes cenários de destinação dos resíduos sólidos orgânicos coletados no Distrito Federal, Brasil, por meio da metodologia de Avaliação do Ciclo de Vida (ACV). Quatro cenários de gestão dos resíduos sólidos orgânicos foram avaliados considerando diferentes formas de destinação, compostagem e aterro sanitário, e diferentes estratégias adotadas no controle das emissões gasosas do aterro sanitário, queima do biogás e aproveitamento energético. 0 consumo de energia, insumos, recuperação de materiais e as emissões foram quantificadas e avaliadas em termos de sua contribuição para as categorias de aquecimento global, toxicidade humana, acidificação e eutrofização. Os resultados demostraram que reduções significativas dos potenciais impactos de aquecimento global e toxicidade humana podem ser obtidas com a compostagem da fração orgânica. No entanto no processo da compostagem devem ser adotadas formas de controle das emissões gasosas que causam o aumento dos potenciais de acidificação e eutrofização. 0 aproveitamento energético do gás do aterro apresentou os melhores resultados em todas as categorias.

Palavras-Chave: ACV, compostagem, aterro sanitário 


\section{INTRODUÇÃO}

A gestão dos Resíduos Sólidos Urbanos (RSU) se tornou um dos principais desafios para os municípios, principalmente, nos países em desenvolvimento, onde o crescimento da população, urbanização e desenvolvimento econômico aumentaram significativamente a geração dos RSU (CHERUBINI et al., 2009; HAVUKAINEN et al., 2017). Devido as implicações na saúde pública, segurança e meio ambiente, é necessária uma gestão eficiente dos RSU (COELHO e LANGE, 2018; MCDOUGALL et al., 2001).

No Distrito Federal (DF) foram coletadas 829.229 toneladas de RSU em 2017, sendo a maior parte encaminhada para um aterro controlado, fechado completamente em 2018, e para o aterro sanitário de Brasília (SLU, 2018). Embora os aterros sanitários sejam construídos para proteger o meio ambiente, ainda existem alguns efeitos adversos dessa prática. Portanto, é importante avaliar diferentes estratégias de tratamento dos resíduos para diminuir a carga sobre o meio ambiente (GOMES et al., 2015).

Essa crescente preocupação com relação a gestão dos RSU tem motivado o desenvolvimento e aplicação de instrumentos e métodos que auxiliem na compreensão, no controle e redução dos impactos associados a esta atividade (GOMES et al, 2015). Neste contexto, a Avaliação do Ciclo de Vida (ACV) é uma das metodologias mais utilizadas para avaliar os sistemas de gestão dos resíduos sólidos. A ACV consiste em avaliar os efeitos ambientais relacionados a um produto ou processo, desde a aquisição da matéria-prima até a sua disposição final. Dessa forma, a ACV pode ser utilizada como uma ferramenta de apoio a tomada de decisão com relação aos impactos que diferentes estratégias adotadas em um sistema tem sobre o meio ambiente (COELHO e LANGE, 2018).

\section{OBJETIVO}

O objetivo deste estudo é avaliar os potenciais impactos ambientais de diferentes cenários de destinação dos Resíduos Sólidos Orgânicos (RSO) coletados no Distrito Federal (DF), Brasil, por meio da metodologia da Avaliação do Ciclo de Vida (ACV).

\section{METODOLOGIA}

A metodologia utilizada é baseada na ACV. De acordo com a NBR ISO 14.040 (2009), um estudo de ACV possui quatro fases: definição do objetivo e escopo, inventário do ciclo de vida, avaliação dos impactos ambientais e interpretação dos resultados.

\subsection{OBJETIVO E ESCOPO DA ACV}

O objetivo da ACV foi comparar os potenciais impactos de diferentes estratégias que podem ser adotadas na gestão dos RSO no DF. A unidade funcional selecionada, que permite a comparação dos diferentes cenários, foi 829.229 toneladas de Resíduos Sólidos Urbanos (RSU), que foi a quantidade coletada no DF em 2017 (SLU, 2018). A composição dos RSU coletados no Distrito Federal é apresentada na Tabela 1.

Tabela 1: Composição dos RSU do Distrito Federal.

\begin{tabular}{|l|c|}
\hline Fração dos Resíduos & Percentual (\%) \\
\hline Plástico & 11,4 \\
\hline Papel & 7,9 \\
\hline Metais & 1,5 \\
\hline Vidro & 2 \\
\hline Orgânico & 37,2 \\
\hline Rejeitos & 36 \\
\hline Outros & 4 \\
\hline
\end{tabular}

Fonte: SLU, 2015.

A ACV foi realizada para quatro cenários de gestão dos RSO no Distrito Federal. Nos Cenários 1 e 2 todo resíduo coletado é destinado para um aterro sanitário, com diferentes estratégias adotadas no controle das emissões gasosas. No Cenário 1 o biogás é coletado e queimado no local, enquanto no Cenário 2 o biogás é utilizado em uma turbina a gás para produção de eletricidade. Nos Cenários 3 e 4, 50\% dos RSO são direcionados para compostagem e o restante é direcionado ao aterro sanitário, esta quantidade de 
RSO destinado para compostagem foi calculada para atender as metas do Plano Nacional de Resíduos Sólidos para a região Centro-Oeste (BRASIL, 2012). No Cenário 3 o gás do aterro sanitário é queimado no local, enquanto no Cenário 4 é utilizado para produzir eletricidade.

A fronteira do sistema incluiu as diferentes formas de destinação dos RSO (compostagem e aterro sanitário) e as estratégias adotadas no controle das emissões de um aterro sanitário (queima do biogás ou aproveitamento energético). As emissões diretas das operações e as indiretas da aquisição de materiais, como combustível e eletricidade, foram consideradas. Para evitar alocação entre as saídas, como aconselhado na norma NBR ISO 14.044 (2009), uma expansão do sistema foi utilizada, que permiti incluir na ACV os créditos obtidos pela produção da energia e do composto. A Figura 1 apresenta a fronteira do sistema deste estudo.

Figura 1: Fronteira do sistema.

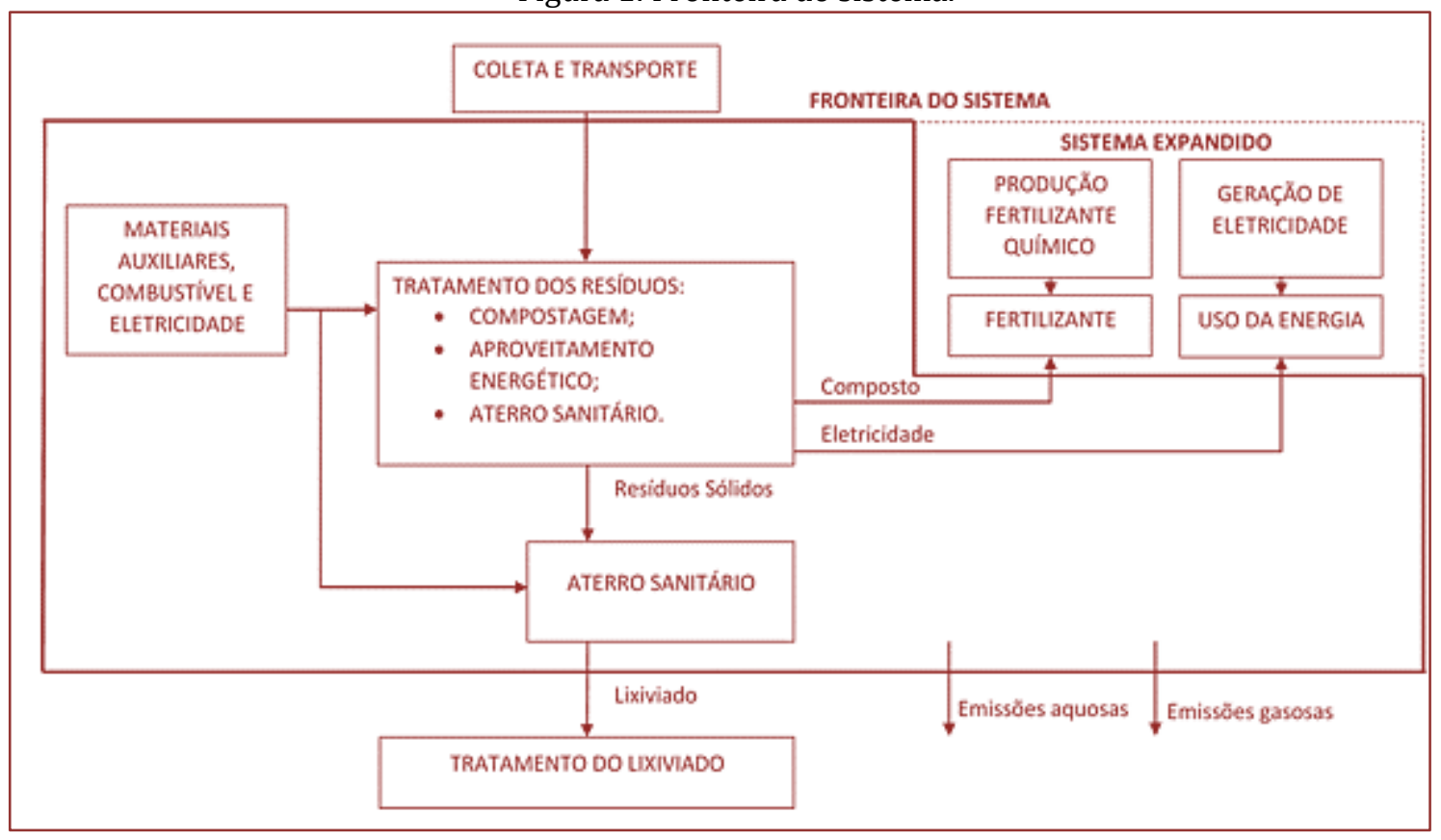

Foi assumido que $80 \%$ do lixiviado do aterro é coletado e transportado para uma unidade de tratamento e os $20 \%$ restante irá vazar diretamente para os corpos aquáticos. Não foram incluídos o uso de recursos ou emissões relacionadas ao transporte e tratamento do lixiviado, como considerado por Finnveden et al. (2000). As emissões produzidas pela construção das unidades de tratamento não são estimadas neste estudo. Segundo Assamoi e Lawryshyn (2012), essas emissões são pequenas quando comparadas com as emissões devido ao uso dessas unidades.

\subsection{INVENTÁRIO DO CICLO DE VIDA}

O Inventário do Ciclo de Vida visa determinar os fluxos de massa, ou seja, as entradas e saídas, do sistema em estudo. 0 consumo de energia, entrada de recursos, recuperação de materiais e as emissões para o ar (CO2, CH4, SO2, NO2, N2O, H2S, HCl, HF, NH3, CFCs, HCFCs, COVs, Dioxinas e Furanos) e para água (DBO, DQO, N-total e P-total) foram estimados para todos os cenários. As emissões relacionadas as diferentes formas de tratamento do resíduo consideradas neste estudo foram calculadas com base nos dados disponíveis na literatura e de alguns processos disponíveis na base de dados do software GaBi.

Os dados de geração da energia elétrica são referentes a matriz elétrica brasileira. As emissões relacionadas ao uso da energia foram calculadas com o software GaBi, que considera a matriz elétrica brasileira com as proporções apresentadas na Tabela 2. 
Tabela 2: Matriz elétrica brasileira.

\begin{tabular}{|l|c|}
\multicolumn{1}{|c|}{ Fonte } & Percentual (\%) \\
\hline Hidrelétrica & $63,26 \%$ \\
\hline Gás natural & $13,74 \%$ \\
\hline Biomassa & $7,7 \%$ \\
\hline Derivados do petróleo & $6 \%$ \\
\hline Carvão & $3,19 \%$ \\
\hline Nuclear & $2,61 \%$ \\
\hline Eólica & $2,07 \%$ \\
\hline Lignito & $1,34 \%$ \\
\hline Biogás & $0,09 \%$ \\
\hline \multicolumn{2}{|c|}{ Fonte: Thinkstep 2018} \\
\hline
\end{tabular}

Fonte: Thinkstep, 2018.

Esses dados também foram utilizados para calcular as emissões evitadas pelo aproveitamento energético do gás do aterro.

Os principais dados utilizados na modelagem do aterro sanitário e das formas de controle das emissões (queima do biogás e aproveitamento energético) são apresentados em Cherubini et al. (2009) e Mcdougall et al. (2001). Para a modelagem da compostagem foram utilizados os dados apresentados em Banar et al. (2009) e Finnveden et al. (2000). A composição do composto produzido considerada foi um valor médio das faixas de variação dos nutrientes (N e P) apresentadas em Boldrin et al. (2009). 0 material substituído é um fertilizante inorgânico contendo uma quantidade equivalente destes nutrientes ( $\mathrm{N}$ e P). Os dados do inventário do ciclo de vida do fertilizante inorgânico substituído foram obtidos do banco de dados do software GaBi.

\subsection{AVALIAÇÃO DOS IMPACTOS AMBIENTAIS}

Os potenciais impactos ambientais foram avaliados usando os dados coletados na fase do inventário. As entradas e saídas foram relacionadas a categorias de impacto e seus potencias quantificados de acordo com determinados fatores de caracterização. Neste estudo, as categorias de impacto ambiental incluídas foram o potencial de acidificação, potencial de eutrofização, potencial de aquecimento global e potencial de toxicidade humana. A modelagem do estudo foi realizada com o software GaBi e a metodologia de avaliação de impactos CML 2001 (GUINÉE, 2002).

\section{RESULTADOS}

Nas Figuras 2-5 são apresentados os potencias impactos para os diferentes cenários considerados neste estudo. Um valor negativo significa um benefício /crédito ambiental, enquanto um valor positivo indica uma carga ambiental.

Figura 2: Potencial de Aquecimento Global dos cenários.

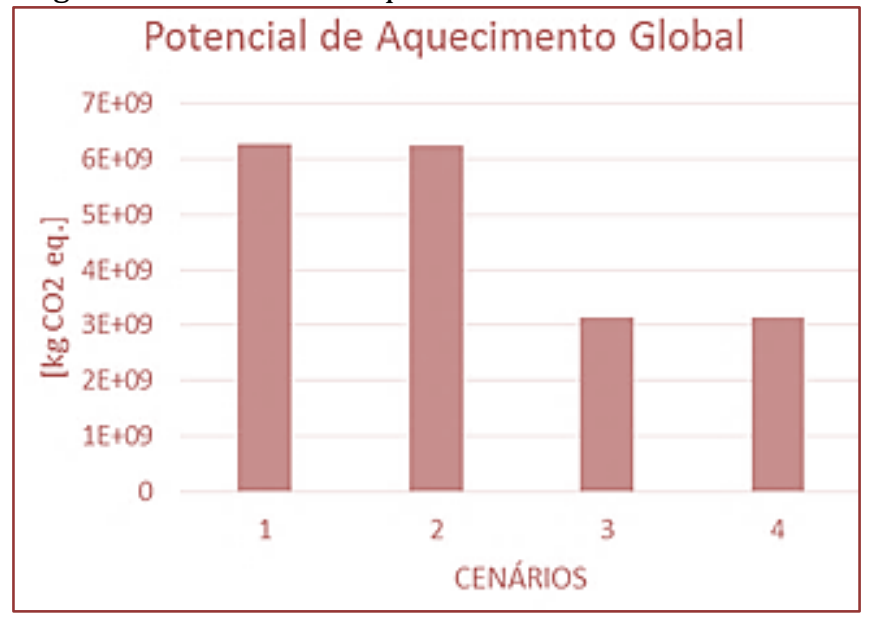


Figura 3: Potencial de Toxicidade Humana dos cenários.

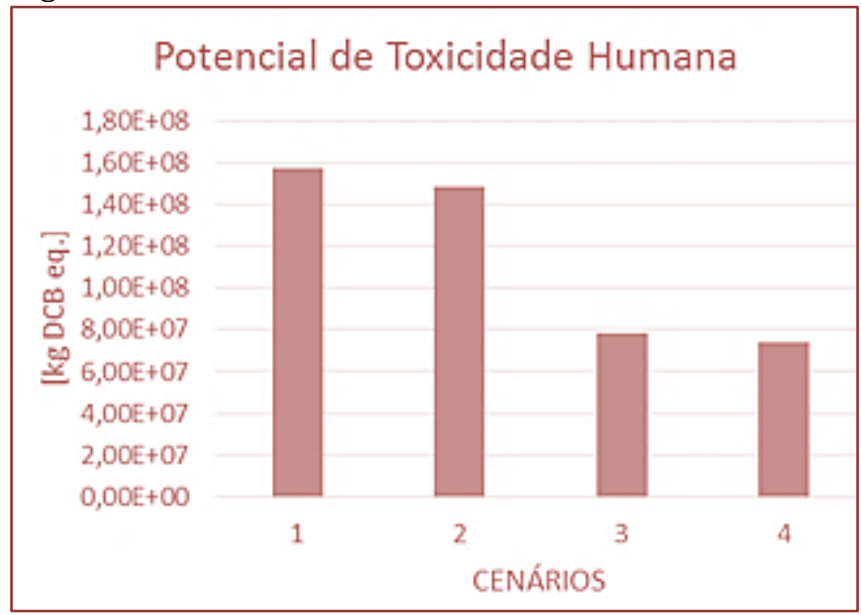

Com relação ao potencial de aquecimento global (Figura 2), expresso em $\mathrm{kg} \mathrm{CO}_{2}$ eq., os cenários nos quais todo o RSO é destinado ao aterro sanitário, cenários 1 e 2, apresentaram os maiores índices desta categoria de impacto. Nos cenários 3 e 4, que parte dos RSO foram destinados para a compostagem, houve uma redução significativa deste potencial impacto, pois com a diminuição da fração biodegradável nos resíduos que são dispostos no aterro sanitário menos gases são emitidos.

Já o aproveitamento energético do biogás tem uma contribuição pequena na redução do potencial de aquecimento global, pois a maior parte da energia elétrica produzida no Brasil é de fontes com baixa emissão de gases de efeito estufa (COELHO e LANGE, 2018).

O potencial de toxicidade humana (Figura 3), expresso em kg DCB eq., apresentou um comportamento semelhante a categoria de aquecimento global. Assim, os cenários que consideraram a compostagem como alternativa de tratamento dos RSO apresentaram menores índices de toxicidade humana, uma vez que o aterro sanitário é a etapa que mais contribuiu para o aumento deste potencial impacto.

Figura 4: Potencial de Acidificação dos cenários.

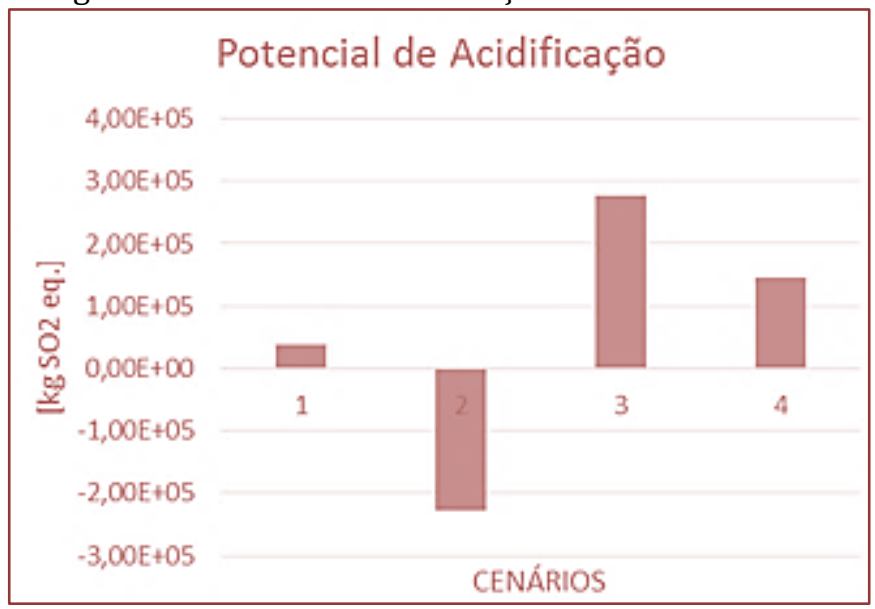


Figura 5: Potencial de Eutrofização dos cenários.

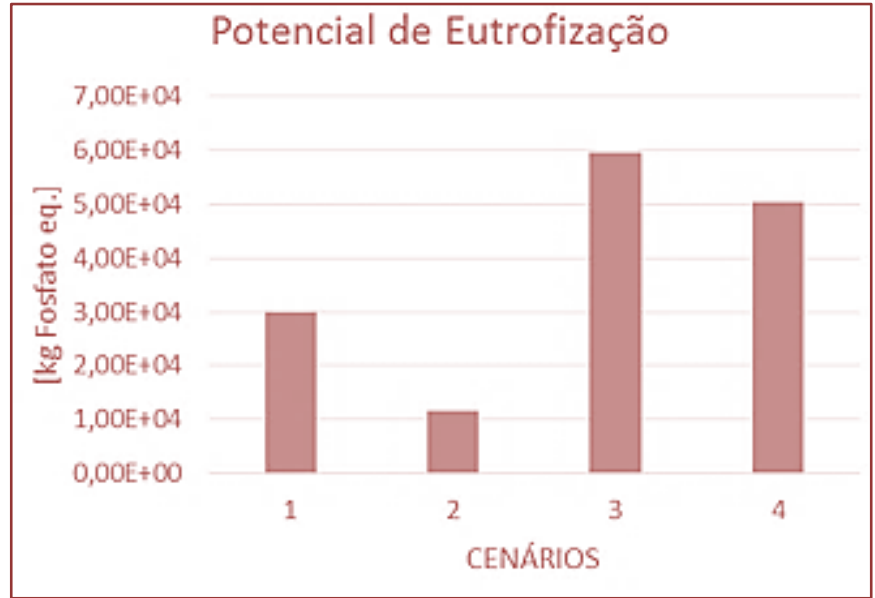

Com relação ao potencial de acidificação (Figura 4), expresso em $\mathrm{kg} \mathrm{SO}_{2}$ eq., os cenários 3 e 4 apresentaram os maiores impactos adverso, devido as emissões de $\mathrm{NH}_{3}, \mathrm{NO}_{2}$ e $\mathrm{SO}_{2}$, que são relacionados ao processo da compostagem. 0 aproveitamento energético do biogás teve uma influência maior nos resultados da acidificação do que nos de aquecimento global. 0 valor negativo do indicador no cenário 2 expressa que a acidificação evitada foi maior que a produzida pelos outros processos considerados neste cenário.

No potencial de eutrofização (Figura 5), expresso em $\mathrm{kg} \mathrm{PO}_{4}$ eq., os cenários com aterros sanitários precedidos por compostagem apresentaram os piores índices desta categoria de impacto, principalmente, devido a emissão sem controle de $\mathrm{NH}_{3}$. Nos cenários onde o biogás foi utilizado para produção de eletricidade houve uma redução do potencial de eutrofização quando comparado com os cenários onde o biogás foi queimado, no entanto a eutrofização evitada pelo uso da eletricidade proveniente dos resíduos não foi maior que a produzida pelos outros processos considerados nesses cenários, indicando uma carga ambiental.

\section{CONCLUSÕES}

Neste estudo foi realizada uma ACV de diferentes cenários de destinação dos RSO coletados no Distrito Federal. A ACV permitiu comparar o efeito ambiental de cada cenário estudado considerando várias categorias de impacto e mostrou-se como uma ferramenta valiosa para ajudar no planejamento de um sistema de gestão dos resíduos sólidos que seja ambientalmente favorável.

De acordo com os resultados, os cenários que os RSO foram destinados para a compostagem apresentaram menores potenciais de impactos apenas nas categorias de aquecimento global e toxicidade humana. Entretanto os potenciais impactos de acidificação e eutrofização podem ser reduzidos se for considerada alguma forma de controle e tratamento das emissões gasosas no processo da compostagem. Com relação as diferentes formas de tratamento do gás do aterro, o aproveitamento energético mostrou-se como uma alternativa melhor que a queima do biogás.

Os cenários de gestão dos RSO foram investigadas somente do ponto de vista ambiental. Portanto, outras ferramentas que considerem os efeitos econômicos e sociais das diferentes estratégias devem ser consideradas no processo de tomada de decisão.

\section{REFERÊNCIAS}

[1] Associação Brasileira de Normas Técnicas (ABNT). NBR ISO 14.040: Gestão Ambiental - Avaliação do Ciclo de Vida - Princípios e estrutura. Rio de Janeiro, 2009.

[2] Associação Brasileira de Normas Técnicas (ABNT). NBR ISO 14.044: Gestão Ambiental - Avaliação do Ciclo de Vida - Requisitos e orientações. Rio de Janeiro, 2009.

[3] Assamoi, B.; Lawryshyn, Y. The environmental comparison of landfilling vs. incineration of MSW accounting for waste diversion. Waste Management, v. 32, n. 5, p. 1019-1030, 2012. 
[4] Banar, M.; Cokaygil, Z.; Ozkan, A. Life cycle assessment of solid waste management options for Eskisehir, Turkey. Waste management, v. 29, n. 1, p. 54-62, 2009.

[5] Boldrin, A. et al. Composting and compost utilization: accounting of greenhouse gases and global warming contributions. Waste Management \& Research, v. 27, n. 8, p. 800-812, 2009.

[6] Brasil. Ministério do Meio Ambiente. Plano Nacional de Resíduos Sólidos. Ministério do Meio Ambiente. Governo Federal. Brasília: MMA. 2012

[7] Cherubini, F.; Bargigli, S.; Ulgiati, S. Life cycle assessment (LCA) of waste management strategies: Landfilling, sorting plant and incineration. Energy, v. 34, n. 12, p. 2116-2123, 2009.

[8] Coelho, L. M. G.; Lange, L. C. Applying life cycle assessment to support environmentally sustainable waste management strategies in Brazil. Resources, Conservation and Recycling, v. 128, p. 438-450, 2018.

[9] Finnveden, G. et al. Life cycle assessments of energy from solid waste. Stockholms Universitet, 2000.

[10] Gomes, L. P. et al. Avaliação ambiental de aterros sanitários de resíduos sólidos urbanos precedidos ou não por unidades de compostagem. Engenharia Sanitária e Ambiental, v. 20, n. 3, p. 449-462, 2015.

[11] Guinée, J. B. Handbook on Life Cycle Assessment: Operational Guide to the ISO Standards. Eco-efficiency in Industry and Science Series, v. 7, p. 692, 2002.

[12] Havukainen, J. et al. Environmental impact assessment of municipal solid waste management incorporating mechanical treatment of waste and incineration in Hangzhou, China. Journal of cleaner production, v. 141, p. 453-461, 2017.

[13] Mcdougall, F. R.; White, P. R.; Franke, M.; Hindle, P. Integrated solid waste management: a life cycle inventory. Blackwell Science Ltd., Oxford, 2001.

[14] Serviço de Limpeza Urbana (SLU). Relatório da análise gravimétrica dos resíduos sólidos urbanos do Distrito Federal - 2015. Disponível em: <www.slu.df.gov.br>. Acesso em: 2 outubro 2018.

[15] Serviço de Limpeza Urbana (SLU). Relatório de atividades SLU - 2017. Disponível em: <www.slu.df.gov.br>. Acesso em: 15 setembro 2018.

[16] Thinkstep. GaBi LCA Software. 2018. Disponível em: <www.thinkstep.com/software/gabi-lca>. 


\section{Capítulo 6}

Resíduos sólidos no município de Juruti/PA, cenário atual e propostas para atendimento da Lei 12.305/2010, com aproveitmanto energetico para geração de energia elétrica

\section{Euller da Conceição Tavares}

Elden de Albuquerque Marialva

Ana Lídia Picanço Moreira

Sostenes de Souza Moreira

Elinaldo Alves

Resumo: 0 gerenciamento de resíduos sólidos no país é debatido pelos seguimentos de proteção ambiental e de saúde, estando amplamente contemplado pela legislação em vigor, atualmente é baixo o índice de municípios que se adequaram essas legislações no país. O Atendimento da lei 12.305/2010 no que tangem os resíduos sólidos tem sido um gargalo para a gestão pública. Neste artigo será apresentado o cenário atual dos resíduos sólidos gerados no Município de Juruti/PA, mostrado os arranjos produtivos locais a partir desses resíduos, propondo duas alternativas alinhadas com legislação em vigor, que podem ser adotadas pela gestão pública local ou mesmo iniciativa privada que tenham interesse em investir nesse setor.

Palavras-chave: Gestão de resíduos sólidos; aproveitamento energético; disposição final dos RSU. 


\section{INTRODUÇÃO}

A expansão dos centros urbanos impulsionou o consumo e a geração de produtos para atender as mais diversas necessidades do homem moderno, esses resíduos quando inutilizados são descartados no meio ambiente, desta forma, o gerenciamento ambientalmente correto dos resíduos sólidos é tema de preocupação para a gestão pública do país.

A Lei 12.305/2010, que institui a Política Nacional de Resíduos Sólidos (PNRS), é um instrumento importante para permitir o avanço necessário ao País no enfretamento dos principais problemas ambientais, sociais e econômicos decorrentes do gerenciamento inadequado dos Resíduos Sólidos Urbanos (RSU). (LUCKE, 2012).

No ano de 2017 o Brasil gerou 78,4 milhões de toneladas de RSU, destes apenas 91,2 \% desse montante fora abrangido pelo serviço de coleta. Em relação a disposição final desses resíduos coletados $51,1 \%$ de RSU foram despejados em aterros sanitários e quase $40 \%$ foram dispostos em lugares inadequados por 3.352 municípios do país. (ABRELPE, 2017).

Objetiva-se com esse trabalho, identificar a geração, coleta, disposição final e os arranjos produtivos locais a partir dos RSU no município de Juruti-PA, e com base nos resultados auferidos, em acordo com legislação hodierna, propor ao município dois cenários corroborativos a um gerenciamento ambientalmente correto para os RSU.

\section{METODOLOGIA}

A metodologia fundamentou-se em quatro etapas. Inicialmente realizou-se identificação sobre o gerenciamento dos RSU no município de Juruti/PA, junto aos órgãos municipais, a partir dos dados obtidos fora calculado a geração dos resíduos em concordância com o PNRS para o índice populacional do Município (IBGE, 2017). A segunda etapa, foram realizadas visitas aos lixões do município para verificar "in locu" a forma de disposição dos resíduos Ademais, na terceira foi aplicado um questionário via método dialético e exploratório, procedimento pelo qual permite indagação direta as pessoas (PRODANOV, FREITAS, 2013), com intuito de identificar os arranjos produtivos locais, e o tipo de resíduos que são coletados por estes seguimentos. Na última etapa, os dados foram auferidos, processados, analisados e por fim, fora proposto dois cenários para o gerenciamento dos RSU no município, embasado em tecnologias consolidadas, com ênfase na compostagem, reciclagem (ABRELPE, 2015) e aproveitamento energético através da incineração dos RSU para obtenção de energia elétrica (ITÔ, 2014).

\section{RESULTADOS E DISCUSSÃO}

Como primeiro resultado, fora identificado uma geração 65,3 T/dia de resíduos sólidos em Juruti, das quais deste, $48 \%$ são orgânicos; $24 \%$ plásticos; $12 \%$ papel e papelão; $8 \%$ metais; $2 \%$ vidro e $6 \%$ poda de árvores e capina. A logística da coleta pública dos resíduos sólidos abrange todos os domicílios e estabelecimentos do meio urbano e parcialmente alguns distritos em comunidades sedes da zona rural. 0 município possui 5 lixões, dos quais três estão nos distritos rurais e dois próximos ao meio urbano.

Nas visitas "in locu" aos lixões, constatou-se que todos os resíduos coletados pelo serviço público, são despejados diretamente no solo; a queima desses resíduos forma uma fumaça escura ao entorno; presença de animais como coragyps atratus, rattus norvegicus, canis lúpus familiaris; e presença de catadores.

Os arranjos produtivos locais identificados, foram: duas sucateiras; e uma Cooperativa de catadores, esses seguimentos coletam 2,43 T/dia de resíduos recicláveis e são vendidos para as indústrias e atravessadores da região ou do Estado do Amazonas. 0 município tem potencial de gerar 28,73 T/dia de resíduos recicláveis, entretanto apenas 8,5 \% desses resíduos são coletados.

Após análise é sugerido dois cenários para a gestão de RSU no município, o primeiro cenário contempla três mecanismos: compostagem, reciclagem e a disposição de rejeitos em aterro sanitário (ABRELPE, 2015). Este cenário compreende o processamento por seleção manual e reaproveitamento dos resíduos, na qual poderá ser feita em parcerias junto com as sucatarias e cooperativa locais. Ademais a disposição final dos rejeitos, deve ser realizada em aterros sanitários (CATAPRETA, 2008). 
0 segundo cenário inclui o aproveitamento energético das $28,76 \mathrm{~T} /$ dia de resíduos gerados no município, através da incineração para geração de energia, este cenário propõe quatro mecanismos, o primeiro propõe compostagem em pequena escala, utilizando $30 \%$ dos resíduos orgânicos. 0 segundo contempla a reciclagem visando parcerias locais e utilização de usina de processamento, para alcançar um aproveitamento de até $90 \%$ dos recicláveis. 0 terceiro mecanismo é a incineração "mass burning" (ITÔ, 2014), para esse mecanismo recomendam-se utilizar $70 \%$ dos resíduos orgânicos; $10 \%$ de recicláveis; 3,92 T/dia de poda de arvores, totalizando 28,76 T/dia de resíduos para a incineração. Essas usinas podem atingir entre 300 a $600 \mathrm{kWh} / \mathrm{t}$ de energia (DEA, 18/14), com o montante dos RSU do Município separados para a incineração, será possível atingir até $13 \mathrm{MW} /$ dia de energia. O sistema possuirá tratamento de gases e emitirão particulados dentro do limite estipulado pelo CONAMA. O quarto mecanismo contempla a utilização das cinzas oriundas do processo da incineração, que servirão de insumos para construção civil (fabricação de cimento, bloquete, etc.), inibindo o uso de aterros sanitários.

Para fins de ilustração, estão listados a seguir um diagrama esquemático de uma Usina de Recuperação Energética de RSU para Juruti (figura 01) e os principais equipamentos (tabela 01).

Figura 01: Diagrama esquemático de uma Usina de Recuperação Energética de RSU para Juruti.

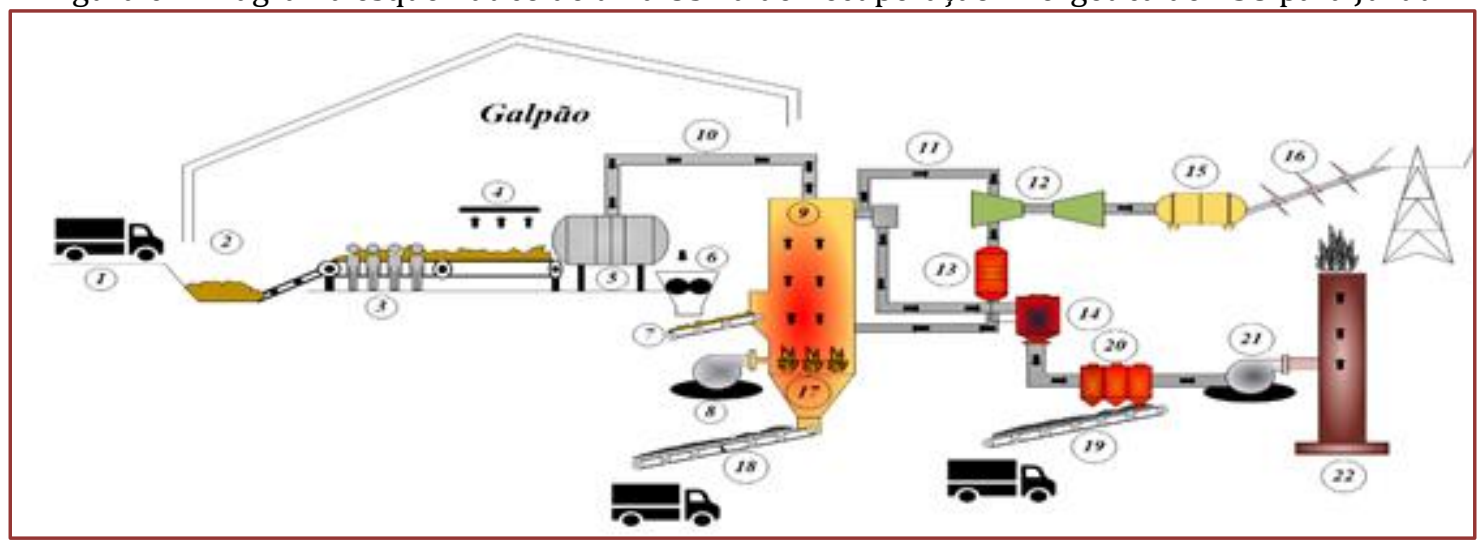

Tabela 01: Equipamentos do diagrama esquemático

\begin{tabular}{|c|l|c|l|}
\hline \multicolumn{1}{|c|}{ Item Descrição } & Item & \multicolumn{2}{c|}{ Descrição } \\
\hline 1 & Local de descarga dos RSU & 12 & Turbina a vapor \\
\hline 2 & Poço de armazenamento dos RSU & 13 & Condensador \\
\hline 3 & $\begin{array}{l}\text { Separação de resíduos recicláveis, realizado pelos } \\
\text { arranjos produtivos locais; }\end{array}$ & 14 & Lavador de gases \\
\hline 4 & Eletroímãs & 15 & Gerador \\
\hline 5 & Secador, aquecido com o calor da caldeira & 16 & Rede de distribuição elétrica \\
\hline 6 & Triturador de dois rolos & 17 & Grelha de incineração \\
\hline 7 & Correia transportadora de resíduos para dentro & 18 & Transportador de cinzas da caldeira \\
\hline 8 & Aa caldeira & 19 & Transportador de cinzas do filtro \\
\hline 9 & Caldeira & 20 & Filtros \\
\hline 10 & Captação térmica para o secador & 21 & Ventilador de tiragem induzida \\
\hline 11 & Vapor & 22 & Chaminé \\
\hline
\end{tabular}

\section{CONSIDERAÇÕES FINAIS}

O estudo evidencia um reflexo antagônico de um gerenciamento eficaz de resíduos sólidos no município de Juruti/PA, indo na contramão da legislação em vigor, entretanto é possível alinhar os interesses do setor ambiental, social e econômico para mudar a atual situação local em relação ao gerenciamento dos RSU, para isso propormos no estudo dois cenários, configurando-se um importante avanço para prevenção do meio ambiente e da saúde pública, esses cenários podem ser adotadas pela gestão pública local ou mesmo iniciativa privada que tenham interesse em investir nesse setor.. 


\section{REFERÊNCIAS}

[1] Abrelpe. Estimativas dos Custos Para Viabilizar a Universalização da Destinação Adequada de Resíduos Sólidos no Brasil, 2015.

[2] Abrelpe. Panorama dos Resíduos Sólidos do Brasil, 2017.

[3] Catapreta, C. A. A. Comportamento de um aterro sanitário experimental: Avaliação da influência do projeto, construção e operação. Tese Apresentada no Programa de Pós-Graduação em Saneamento, Meio Ambiente e Recursos Hídricos da UFMG, como requisito parcial à obtenção de Título de Doutor em Saneamento, Meio Ambiente e Recursos Hídricos. Escola De Engenharia UFMG, Belo Horizonte, 2008.

[4] EPE- Empresa de Pesquisa Energética. Nota Técnica DEA 18/14. Inventário Energético dos Resíduos Sólidos Urbanos. Ministério de Minas e Energia. Rio de Janeiro. Out. 2014.

[5] IBGE. 2017. Cidades / Juruti. IBGE (Online), https://www.ibge.gov.br/cidades-e-estados/pa/juruti.html, 2017. Acesso em: 02 abr. 2019, 15:30h.

[6] Itô, Leandro Cesar Maser. Geração de energia elétrica a partir dos resíduos sólidos urbanos. Tese apresentada no Curso de Engenharia Elétrica com Ênfase em Sistemas de Automação, como requisito a obtenção de Título de Engenharia Elétrica com Ênfase em Sistemas de Automação. Escola de Engenharia de São Carlos USP, São Carlos 2014.

[7] Lei 12.305 de 02 de agosto de 2010. Institui a Política Nacional de Resíduos Sólidos; altera a Lei n. 9.605, de 12 de fevereiro de 1998; e dá outras providências. DF, Brasília, Planalto, Casa Civil, 2010a. Disponível em: <http://www.planalto.gov.br/ccivil_03/_Ato2007-2010/2010/Lei/L12305.htm>. Acesso em: 12 abr. 2019, 16:00h.

[8] Lucke, Sergio Augusto. O resíduo sólido urbano como fonte renovável para geração de energia elétrica: aspectos econômicos e socioambientais. 1v 437p. Tese de Doutorado apresentada a Faculdade de Engenharia Civil, Arquitetura e Urbanismo da Universidade Estadual de Campinas, Campinas, 2012. Disponível em <http://www.bibliotecadigital.unicamp.br/document/?code=000905628> Acesso em 12/08/2019

[9] Metodologia do trabalho científico [recurso eletrônico] : métodos e técnicas da pesquisa e do trabalho acadêmico / Cleber Cristiano Prodanov, Ernani Cesar de Freitas. - 2. ed. - Novo Hamburgo: Feevale, 2013. 


\title{
Capítulo 7
}

\section{Avaliação da disposição dos Resíduos Sólidos Urbanos de Rebouças em Aterro Sanitário}

\author{
Nathana Cipriano Ulchak
}

Ana Karoline Domiciano

Giovana Ranthum Viechneiski

Sílvia Carla da Silva André Uehara

Tatiane Bonametti Veiga

Resumo: A urbanização e o intenso do crescimento das cidades culminou no aumento na geração dos resíduos sólidos, sendo esse um problema mundial. No Brasil, um grande marco foi a publicação de Lei $\mathrm{n}^{0}$ 12.305, a qual Instituiu a Política Nacional de Resíduos Sólidos, sendo exigido, dos municípios brasileiros, a elaboração dos Planos Municipais de Gestão Integrada de Resíduos Sólidos. Nesse contexto, discussões sobre a melhor forma de gestão dos resíduos sólidos enfatizam a importância do conhecimento das características dos resíduos sólidos urbanos. Portanto, é fundamental um diagnóstico preciso para a elaboração de soluções adequadas e dimensionamento nas operações envolvidas no gerenciamento para cada município. 0 presente estudo consiste em um levantamento e análise de dados dos resíduos sólidos urbanos encaminhados mensalmente ao aterro sanitário do município de Rebouças-PR. Para isso, foram levantados dados secundários fornecidos pela prefeitura quanto a coleta e destinação dos resíduos encaminhados ao aterro sanitário. Conforme os dados levantados, pode-se notar que a média anual da destinação de resíduos variou de 104,13 a 121,47 toneladas, tendo sofrido uma queda significativa no ano de 2017, em relação aos anos de 2015 e 2016. No ano de 2018, a coleta per capita, obteve o valor médio anual municipal de $0,506 \mathrm{~kg} / \mathrm{hab} /$ dia. Este valor foi relativamente baixo quando comparado com indicadores apresentados por outras instituições, no qual a coleta tem uma média de $0,719 \mathrm{~kg} / \mathrm{hab} /$ dia na região sul do país. Porém, quando comparado com a literatura, a coleta per capita do município está dentro da média, onde os estudos apontam que o indicador de coleta é $0,540 \mathrm{~kg} / \mathrm{hab} / \mathrm{dia}$. No ano de 2015, o município apresentou a geração de $51 \%$ dos seus RSU de origem orgânica e $38 \%$ de recicláveis. Estas características demonstram à necessidade da realização de ações voltadas a diminuição do encaminhamento desses resíduos ao aterro sanitário, pois os mesmos deveriam estar sendo reutilizados ou reciclados, proporcionando melhorias quanto às questões econômicas, sociais e ambientais relacionadas à gestão dos resíduos sólidos urbanos no município.

Palavras-Chave: Resíduos Sólidos Urbanos, Caracterização, Gestão de Resíduos Sólidos. 


\section{INTRODUÇÃO}

Desde o início das civilizações, existe a preocupação com a disposição dos resíduos gerados de atividades humanas devido ao risco a saúde que gera para a população. Nos primórdios de nossa história era comum a disposição final em locais afastados dos centros populacionais sem preocupações com danos causados ao meio ambiente (PINHO, 2011).

Com o crescimento das cidades surgiu à necessidade de desenvolvimento nas áreas do saneamento básico. No Brasil, houve um maior investimento nestas áreas com a implementação da Lei $\mathrm{n} \cong 11.445$, a qual estabelece Diretrizes Nacionais para o Saneamento Básico (BRASIL, 2007). Esta lei regulamentou aspectos do saneamento básico, gerenciamento dos resíduos sólidos e da limpeza urbana, além de exigir a elaboração do Plano Municipal de Saneamento Básico (PMSB), o qual deve conter metas para promover melhorias em todas as áreas de saneamento básico. A partir da publicação dessa lei, o PMSB deveria ser executado em todos os municípios com orientações para gestão dos resíduos sólidos urbanos (RSU).

Em 2010, foi publicada a Lei no 12.305 que Instituiu a Política Nacional de Resíduos Sólidos (PNRS), regulamentada pelo decreto no 7.404. A PNRS passou a exigir, dos municípios brasileiros, a elaboração dos Planos Municipais de Gestão Integrada de Resíduos (PMGIRS). Essa lei reforçou muitos conceitos na área dos resíduos, além de destacar a importância da coleta seletiva, da reciclagem dos materiais e da valorização dos resíduos (BRASIL, 2010a, 2010b).

No Brasil, a geração de resíduos sólidos está em amplo crescimento decorrido da expansão populacional e de um maior poder socioeconômico, levando assim ao consumo excessivo, principalmente de materiais descartáveis (MANNARINO; FERREIRA; GANDOLLA, 2016).

Em âmbito nacional, segundo estudos realizados pela Associação Brasileira de Empresas de Limpeza Pública e Resíduos Especiais (ABRELPE), mesmo na situação em que o Brasil encontra-se em plena crise econômica, produziu, no ano de 2017, 78,4 milhões de toneladas RSU no ano, o qual sofreu um aumento referente ao ano de 2016 (ABRELPE, 2017). Assim, as discussões sobre a melhor forma de gestão dos resíduos sólidos enfatizam a importância de conhecimento das características dos RSU, como os quantitativos gerados, levando a tomadas de decisão para um sistema de gestão mais eficaz (COLVERO et al., 2017).

Tendo em vista que os aspectos de geração se alteram em municípios de pequeno, médio e grande porte, é fundamental um diagnóstico preciso e atualizado para a elaboração de soluções adequadas e dimensionamento nas operações envolvidas no gerenciamento para cada município (PISANI JUNIOR; CASTRO; COSTA, 2018).

Nesse contexto, o presente estudo teve como objetivo avaliar a distribuição dos RSU provenientes de coleta convencional, na cidade de Rebouças, encaminhados ao aterro sanitário.

\section{METODOLOGIA}

Área de estudo

0 estudo foi realizado na cidade de Rebouças localizada no sudeste Paranaense, conforme figura 1, tendo uma extensão territorial de $481,840 \mathrm{~km}^{2}$, com uma pulação estimada de 14.851 hab., sendo que desta população, 7.505 hab. residem em área urbana (IBGE, 2010).

Segundo dados do Instituto Brasileiro de Geografia e Estatística, o município apresenta 55\% de domicílios com esgotamento sanitário adequado, $36.1 \%$ de domićlios urbanos em vias públicas com arborização e $12 \%$ de domicílios urbanos em vias públicas com urbanização adequada (presença de bueiro, calçada, pavimentação e meio-fio), sendo que a coleta convencional e a coleta seletiva existentes no município abrangem 100\% da população urbana (IBGE, 2010).

Até o ano de 2014, os resíduos provenientes da coleta convencional eram dispostos em um lixão municipal, que, atualmente, encontra-se desativado. Em agosto deste mesmo ano, os RSU do município passaram a ser encaminhados para um Aterro Sanitário, localizado no município de Mafra, no estado de Santa Catarina, aproximadamente $150 \mathrm{~km}$ do município de Rebouças, por meio de uma empresa terceirizada contratada pela prefeitura. 
Figura 1: Localização geográfica de Rebouças-PR.

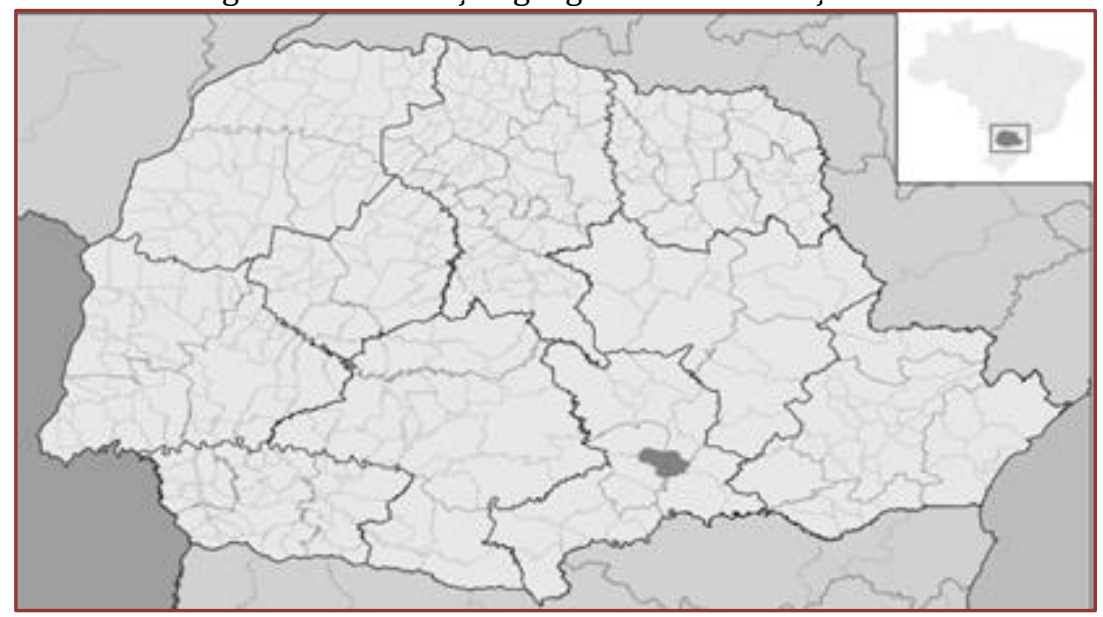

Fonte: Abreu, 2006

\section{Coleta e Análise de dados}

O estudo consistiu em um levantamento e análise de dados de resíduos encaminhados mensalmente ao aterro sanitário. Para isso, foram levantados dados secundários fornecidos pela prefeitura, consulta dos dados provenientes do diagnóstico municipal realizado para a elaboração de um Plano Municipal de Gestão Integrada de Resíduos Sólidos (PMGIRS) e a partir da análise documental fornecida pelo município.

Após coleta de dados, os resultados foram analisados e comparados com os indicadores nacionais e regionais fornecidos pelo Sistema Nacional de Informações sobre Saneamento (SNIS) e Associação Brasileira de Empresas de Limpeza Pública e Resíduos Especiais (ABRELPE), a fim de verificar a situação do município frente aos indicadores fornecidos por essas instituições que apresentam dados por regiões, mas também indicadores nacionais.

\section{RESULTADOS}

Desde o início da destinação dos RSU de Rebouças para o aterro sanitário, em agosto de 2014, o município realiza o registro mensal das quantidades desses resíduos encaminhados ao aterro para fins de liquidação à empresa responsável pelo transporte e disposição dos RSU, a qual realiza a cobrança por tonelada de resíduos. Na tabela 1, constam dados mensais desse encaminhamento, sendo possível observar os registros desde agosto de 2014 até dezembro de 2018.

Tabela 1: Distribuição do encaminhamento dos RSU de Rebouças para o aterro sanitário

\begin{tabular}{|c|c|c|c|c|c|}
\hline \multicolumn{6}{|c|}{ RSU Produzidos pela cidade de Rebouças/PR (ton) } \\
\hline Mês & 2014 & 2015 & 2016 & 2017 & 2018 \\
\hline Janeiro & & 132,36 & 126,98 & 119,21 & 196,7 \\
\hline Fevereiro & & 106,23 & 118,78 & 102,44 & 104,08 \\
\hline Março & & 118,76 & 120,95 & 111,21 & 122,4 \\
\hline Abril & & 106,78 & 107,55 & 88,22 & 102,05 \\
\hline Maio & & 136,72 & 114,15 & 101,15 & 85,33 \\
\hline Junho & & 123,37 & 117,25 & 119,68 & 109,24 \\
\hline Julho & & 136,46 & 108,81 & 107,51 & 112,9 \\
\hline Agosto & 93,9 & 83,91 & & 114,43 & 110,23 \\
\hline Setembro & 93,9 & 128,15 & 205,11 & 104,22 & 117,87 \\
\hline Outubro & 100,9 & 129,23 & 101,45 & 97,96 & 127,07 \\
\hline Novembro & 113,21 & 120,65 & 94,18 & 131,27 & 120,34 \\
\hline Dezembro & 118,73 & 135 & 118,01 & 60,53 & 125,95 \\
\hline Total Anual (ton) & 520,64 & 1457,62 & 1333,22 & 1257,83 & 1434,16 \\
\hline Média Anual (ton) & 104,13 & 121,47 & 121,2 & 104,82 & 119,51 \\
\hline
\end{tabular}

Fonte: Autores, 2019. 
Conforme os dados levantados, pode-se notar que a média anual da destinação de resíduos varia entre 104,13 a 121,47 toneladas, tendo sofrido uma queda significativa no ano de 2017 em relação aos anos de 2015 e 2016, onde a queda pode ser justificada pela implementação da coleta seletiva tendo em vista que este programa é responsável pela redução da quantidade de materiais recicláveis encaminhados aos para aterros sanitários.

Esses resíduos passaram a ser encaminhados para catadores do município, fato esse que possibilita a inserção novamente aos resíduos passíveis de reciclagem na cadeia produtiva como matéria-prima para fabricações de outros produtos. Isto viabiliza dois principais pontos: o aumento de renda aos catadores do município e a diminuição da coleta per capita, a qual está relacionada diretamente no impacto ambiental gerado pelos RSU (PEREIRA; CURI; CURI, 2018).

No ano de 2018, foi observado um aumento no encaminhamento dos RSU ao aterro em relação a 2017, fato que pode indicar falhas no sistema de coleta seletiva. Considerando a coleta per capita, obteve-se o valor médio anual municipal de $0,506 \mathrm{~kg} / \mathrm{hab} /$ dia para a coleta realizada no município, este valor está relativamente baixo quando comparado com indicadores apresentados por outras instituições, no qual a coleta tem uma média de $0,719 \mathrm{~kg} / \mathrm{hab} /$ dia na região sul do país, onde localiza-se o município de Rebouças (ABRELPE, 2017). Esta diferença também pode ser observada com a média diária paranaense apresentada pelo SNIS que corresponde a 0,810 kg/hab/dia (SNIS, 2017).

No entanto, ao comparar o dado obtido para a coleta per capita no município com a literatura, nota-se que o valor encontra-se dentro da média. De acordo com Colvero et. Al. (2017), a geração per capita está relacionada diretamente com o número da população, onde tal geração para municípios com população entre 10.001 a 20.000 habitantes apresentam o valor de geração per capita $0,540 \mathrm{~kg} / \mathrm{hab} /$ dia, sendo esse indicador diretamente proporcional ao indicador de coleta, dependendo da taxa de cobertura de cada município. Vale ressaltar, que embora tenha sido informado que a taxa de cobertura de coleta do município de Rebouças era de $100 \%$, vários fatores podem estar interferindo no indicador de coleta per capita para resultar em um valor a baixo das médias nacionais. Um dos fatores que pode influenciar no indicador de coleta dos RSU levantado no munícipio, corresponde ao serviço de coleta informal realizado por catadores sem cadastro, que não foram contemplados na média anual no presente estudo (Tabela 1).

O dado de coleta per capita é fundamental para o dimensionamento eficaz do sistema de gerenciamento de RSU dos municípios, podendo citar a frequência de coleta, capacidade de caminhões e transbordo, entre outros, podendo influenciar diretamente na tomada de decisão dos gestores públicos (PISANI JUNIOR; CASTRO; COSTA, 2018).

A partir dos resultados obtidos, foi possível organizar os dados para obter uma melhor visualização quanto às variações mensais das toneladas encaminhadas ao aterro sanitário nos diferentes anos analisados (Figura 2).

Figura 2: Gráfico das médias mensais de RSU coletados pelo município de Rebouças

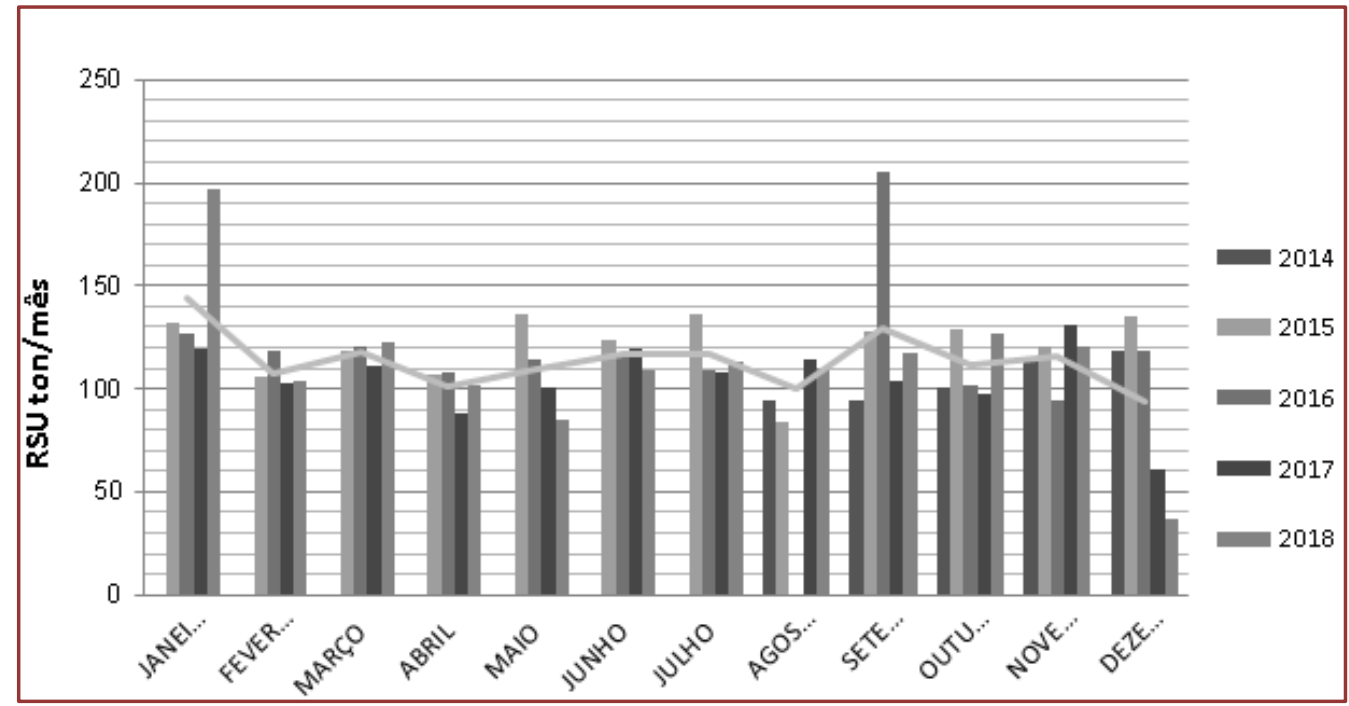

Fonte: Autores, 2019. 
A partir da avaliação das médias de encaminhamento mensais, pode-se destacar os meses de janeiro e setembro, os quais tiveram as médias de 143,81 t/mês e 129,85 t/mês, respectivamente, sendo estas taxas de variações superiores aos demais meses. Esses picos podem ser justificados por possíveis equívocos no registro dos encaminhamentos ao aterro sanitário pelo município, devido a falha de um sistema padrão de registro dos dados. Como, também, é possível realçar que as variações ao longo do ano são consideradas normais, pois recebem influência das estações climáticas, sazonalidade, feriados nacionais, estaduais e municipais, período de férias escolar e demais aspectos relacionados à cultura e costumes da população, podendo levar a alterações na geração dos RSU (IBAM, 2001).

No ano de 2015, foi realizada a caracterização física dos RSU encaminhados ao aterro sanitário, o qual demostrou que a composição física da amostra apresentou 51\% de matéria orgânica, 38\% de materiais recicláveis e $11 \%$ de rejeitos. Destaca-se, o alto percentual dos materiais recicláveis que estão sendo disposto incorretamente no aterro sanitário, quando correlacionado com dados encaminhados no ano da análise, isto significou, aproximadamente, cerca de 554 toneladas de materiais que deixaram de ser reinseridos na cadeia produtiva apenas no ano de 2015.

Quando levado em consideração o valor pago pela prefeitura na disposição dos RSU, o município deixa de economizar uma grande quantia na destinação de seus resíduos devido à má segregação na fonte geradora, sendo que este recurso financeiro poderia estar sendo investido na melhoria do serviço da coleta seletiva e na triagem dos resíduos recicláveis, de modo a garantir o bom atendimento à população e correta destinação dos RSU.

\section{CONCLUSÕES}

Mediante análise dos dados descritos, é possível constatar que o indicador de coleta per capita de 0,506 $\mathrm{kg} / \mathrm{hab} /$ dia do município é aceitável se considerada nas médias estimadas pela literatura quanto à quantidade populacional. Porém, quando comparadas às médias em âmbitos regionais e nacionais, esse valor é considerado relativamente abaixo da média.

É valido salientar as variações das médias mensais ocorridas ao longo do ano, as quais são influenciadas por diversos fatores como o clima, sazonalidade e períodos festivos.

Devido estas variações, é de suma importância o conhecimento da composição gravimétrica a qual propicia um diagnóstico amostral atualizado para a elaboração dos PMGIRS, com propostas efetivas para uma gestão de forma integrada dos RSU, levando em consideração características especificas municipais para auxiliar o processo de tomada de decisão dos gestores.

Outra questão consiste na composição dos RSU gerados, visto que o município apresentou na caracterização gravimétrica a geração de 51\% dos seus RSU de origem orgânica e 38\% de recicláveis, é necessária que se tome medidas voltadas a redução do envio desses resíduos ao aterro sanitário. Sendo assim, recomenda-se um aumento das ações voltadas à educação, conscientização e sensibilização ambiental, bem como, a disseminação da informação para a população quanto ao funcionamento do sistema da coleta seletiva, o incentivo à prática da compostagem doméstica, a organização de cooperativas de catadores no município e maior efetividade na coleta seletiva. Todas essas ações voltadas a reinserção dos resíduos recicláveis novamente a cadeia produtiva, a fim de agregar maior valor desse recurso no ato da venda, bem como proporcionar uma maior sustentabilidade da gestão dos RSU no município.

\section{REFERÊNCIAS}

[1] Abreu, R. L.. Disponível em: <https://Parana_Municip_Reboucas.svg>. Acesso em: 18 mar. 2019.

[2] Associação Brasileira De Empresas De Limpeza Pública E Resíduos Especiais (ABRELPE). Panorama dos resíduos sólidos no Brasil 2017. São Paulo. <http://www.abrelpe.org.br/Panorama/panorama2017.pdf> Acesso em: 18 março de 2019.

[3] Brasil. Lei № 11.445, de 05 de janeiro de 2007. Estabelece diretrizes nacionais para o saneamento básico. Diário Oficial da União. Brasília, DF, 08 jan. 2007.

[4] Decreto no 7.404, de 23 de dezembro de 2010. Regulamenta a Lei no 12.305, que institui a Política Nacional de Resíduos Sólidos. Diário Oficial da União. Brasília, DF, 23 dez. 2010b.

[5] Política Nacional dos Resíduos Sólidos. Lei no 12.305, de 02 de agosto de 2010. Institui a Política Nacional de Resíduos Sólidos. Diário Oficial da União. Brasília, DF, 03 ago. 2010a.

[6] Colvero, D. A. et al. Avaliação da geração de resíduos sólidos urbanos no estado de Goiás, Brasil: análise estatística de dados. Engenharia Sanitaria e Ambiental, v. 22, n. 5, p. 931-941, out. 2017. 
[7] IBAM. Manual de Gerenciamento Integrado de resíduos sólidos. Coordenação técnica Victor Zular Zveibil. Rio de Janeiro: IBAM, 2001. 204p.

[8] Instituto Brasileiro De Geografia E Estatística (IBGE). Censo Demográfico 2010. Disponível em:< https://cidades.ibge.gov.br/brasil/pr/reboucas>. Acesso em: 18 de março de 2019.

[9] Mannarino, C. F.; Ferreira, J. A.; Gandolla, M. Contribuições para a evolução do gerenciamento de resíduos sólidos urbanos no Brasil com base na experiência Européia. Revista Engenharia Ambiental, Rio de Janeiro v.21, n.2, Abr./Jun. 2016.

[10] Pereira, S. S.; Curi, R. C.; Curi, W. F. Uso de indicadores na gestão dos resíduos sólidos urbanos: parte II - uma proposta metodológica de construção e análise para municípios e regiões: aplicação do modelo. Engenharia Sanitária e Ambiental, v. 23, n. 3, p. 485-498, jun. 2018.

[11] Pinho, P.M.O. Avaliação dos planos municipais de gestão integrada de resíduos sólidos urbanos na Amazônia brasileira. 2011. Tese de Doutorado (Ciências Ambiental)-Universidade de São Paulo, São Paulo, 2011.

[12] Pisani Junior, R.; Castro, M. C. A. A.; Costa, A. A.. Desenvolvimento de correlação para estimativa da taxa de geração per capita de resíduos sólidos urbanos no estado de São Paulo: influências da população, renda per capita e consumo de energia elétrica. Engenharia Sanitária e Ambiental, v. 23, n. 2, p. 415-424, 29 mar. 2018.

[13] Prefeitura Municipal De Rebouças. Plano Municipal de Gestão Integrada dos Resíduos Sólidos - PMGIRS. Rebouças -PR, ago. 2016.

[14] Sistema Nacional De Informações Sobre Saneamento (SNIS). Diagnostico do Manejo de Resíduos Sólidos Urbanos de 2017. Brasília. Disponível em: < http://www.snis.gov.br/diagnostico-residuos-solidos> Acesso em: 19 de março de 2019. 


\section{Capítulo 8}

Gestão de resíduos sólidos: Diretrizes de extensão universitária para a Comunidade do Entorno da Escola Superior Pedagógica do Bié, em Angola

\section{Gaspar Sebastião Francisco Cristóvão}

\section{Gerson Araujo de Medeiros}

Resumo: É de singular significado a importância que se outorga hoje em dia, em Angola, ao papel da escola como a principal responsável na formação integral do indivíduo. Para esse fim, contribui especialmente os professores, protagonistas na verdadeira mudança educacional, por meio do apoio, estímulo, promoção e gestão de todo esse processo. Todavia, tais atores não estão isentos de dificuldades, como a deficiência de formação para enfrentar o desafio que significa a introdução da dimensão ambiental em todo o processo de ensino-aprendizagem. A materialização da gestão de resíduos sólidos na comunidade universitária,, requer uma reflexão das relações entre a escola e seu entorno, a partir de todos os atos de caráter metodológicos do trabalho consciente do professor, do aluno e demais atores da comunidade. Portanto, torna-se necessário programar ações e encaminhar esforços para formar profissionais da Educação com uma preparação pedagógica, científica e técnica que incorpore os elementos teóricos para a integração da dimensão ambiental nos processos educativos. Tais processos deverão possuir um caráter permanente e dirigido para a comunidade. Precisamente neste contexto se marca o presente capítulo, o qual tem como destinatários a comunidade e a Escola Superior Pedagógica do Bié, em Cuito, Angola. No presente trabalho se discute a questão da extensão universitária expandida, tomando como objeto de estudo a gestão dos resíduos sólidos. Inicialmente se faz uma discussão sobre a gestão dos resíduos sólidos como tema integrador para a educação ambiental. Em seguida se contextualiza a gestão dos resíduos sólidos em Angola. Finalmente, se aprofunda uma discussão sobre a preparação metodológica e os procedimentos para se traçar estratégias de intervenção, apresentando iniciativas de engajamento e mobilização da Escola, por meio de oficinas. Tais experiências buscaram contribuir para a mitigação dos problemas ambientais da gestão de resíduos sólidos, em particular no meio universitário e de seu entorno, o que adquire considerável importância por estar de acordo com a reforma curricular vigente no país.

Palavras-Chave: Educação Ambiental, Gestão Ambiental, Diagnóstico Ambiental. 


\section{EDUCAÇÃO AMBIENTAL E GESTÃO DOS RESíDUOS SóLIDOS}

Os problemas que afetam o meio ambiente são cada vez mais graves e causam preocupação em todos os países do mundo. A Organização das Nações Unidas para a Educação, Ciência e Cultura (UNESCO) reconhece que o meio ambiente da Terra mudou mais aceleradamente nos últimos quarenta anos do que em qualquer outro período comparável da história, tendo como uma causa principal a interação do homem com a Natureza.

Neste sentido, na Conferência das Nações Unidas sobre o Meio Ambiente Humano, realizada em Estocolmo, no ano de 1972, se declarou a necessidade de uma Educação Ambiental. Além disso, se recomendou a adoção das disposições necessárias para se estabelecer um Programa Internacional de Educação sobre o Meio Ambiente que abranja todos os níveis de ensino.

Em Angola, os problemas ambientais constituem uma preocupação constante, pelos seus efeitos no contexto social em que estes se desenrolam.

Atualmente, quando se valoram os problemas ambientais como uma realidade de caráter global, torna-se uma magnífica oportunidade o desenvolvimento de ações direcionadas a sua solução ou mitigação, por meio de uma educação ativa e participativa, com propostas valiosas, úteis e inovadoras, e que sirvam para o progresso da humanidade e da Educação em particular. Por meio da Educação, aporta-se a visão sintetizadora necessária para compreender e interpretar a interação natureza-sociedade, a partir da relação escola-comunidade.

A Educação Ambiental em Angola, segundo as exigências atuais, anseia por uma melhoria do labor educativo que se desenvolve nas instituições de ensino, dirigido a integrar os processos ambientais com os de caráter educacional e atitudinais. Tal labor educativo deve contribuir para o desenvolvimento de uma atitude ambiental positiva, mediante a solução dos problemas ambientais na escala local. Isso se faz mediante a implementação de estratégias, ações educativas e programas, para favorecer o desenvolvimento de uma atitude ambiental positiva nos sujeitos.

Neste processo, desempenha um importante papel a forma de pensar e os estilos de comportamento das pessoas e das comunidades; as políticas dos diferentes setores da economia; da ciência, da educação e da cultura. Nesse contexto, ressalta-se a existência de uma vontade política e a capacidade para integrá-los a partir da aplicação de planos, programas e projetos com a participação da comunidade (Sánchez \& Fabiola, 1998).

As experiências acumuladas e dirigidas ao trabalho comunitário apresentam como tendência: a satisfação das necessidades de subsistência (a alimentação, a construção, a saúde e a proteção ambiental); as necessidades de conhecimento, de afeto, de sentimento, de participação, de recreação, de identidade; e especialmente, de proteção do patrimônio natural, social e cultural da comunidade. (Follari, 1999).

Na sociedade contemporânea se manifesta uma preocupação crescente sobre os aspectos da Educação Ambiental e o papel que corresponde às instituições educativas no seu desenvolvimento. Para tal, diversos autores têm contribuído para essa discussão, como Carlos (2015), Caluhongue (2015), Valdés (2011), Gonçalves (2006), CITMA (2002), Mc Pherson (2002a), Caballero (2001) entre outros. Nesses trabalhos, a Educação Ambiental da Comunidade ocupa um espaço de reflexão constante nas experiências e investigações desenvolvidas.

Não obstante, nas revisões realizadas sobre a base do elemento que intermedia a relação escolacomunidade, se reconhece que:

- Na escala internacional se identifica claramente duas tendências: uma que analisa o vínculo escolacomunidade, orientado a família e destacando a necessidade de reforçar o trabalho da escola, e outra encaminhada a reincorporar a escola ao seu meio;

- No âmbito nacional somente se encontram experiências de escolas que tem desenvolvido algum trabalho com a comunidade, a fim de consolidar o seu labor educativo;

- Na escala local são muito mais escassos os estudos nesta direção, com isoladas experiências que mostrem resultados empíricos;

- Na gestão de resíduos sólidos domésticos (RSD) existe uma forte e marcante "presença cultural" que "dificulta" de certo modo o destino a ser dado aos mesmos. 
Como se aprecia, a escola é a encarregada por excelência de transmitir o sistema de conhecimentos e habilidades acumulados pela sociedade, o que requer uma ampliação nas políticas sociais de desenvolvimento da comunidade, incorporando às demais instituições sociais (formais, não formais e informais) para seja mais efetivo o trabalho educativo de gestão de resíduos orgânicos.

Um marco para a gestão dos resíduos sólidos domésticos em Angola foi a inauguração da Agência Nacional de Resíduos (ANR), em outubro de 2014. Essa agência tem, como principais funções, a regulamentação da atividade de concessão dos serviços públicos no setor de RSD, a execução de políticas públicas para a gestão e gerenciamento de resíduos, além de programas para a prevenção na geração, reutilização, reciclagem, tratamento e disposição final dos mesmos (PEGRU, 2012). Tais programas deverão obedecer a critérios de proteção ambiental, qualidade e eficiência de serviços sem esquecer a viabilidade econômica dos projetos. Esses aspectos, até o presente momento, ainda não passaram do papel para a realidade objetiva da sua criação e aprovação.

A situação revelada, segundo se evidencia no presente capítulo, permitiu declarar o seguinte problema científico: Como contribuir para solucionar as insuficiências que se manifestam na gestão de resíduos sólidos orgânicos da comunidade, desde a Escola Superior Pedagógica do Bié?

O objeto refere-se ao processo de gestão de resíduos orgânicos da comunidade.

O campo de ação corresponde a integração dos processos da gestão dos resíduos sólidos domésticos da comunidade angolana de Cuito, no entorno da Escola Superior Pedagógica do Bié.

O objetivo consiste em elaborar um modelo de estratégia para a integração dos processos da gestão dos RSD da comunidade, desde as instituições educativas.

Nos fundamentos teóricos revisados sobre o tema, ainda resulta insuficiente a sistematização realizada sobre o objeto e o campo de ação da investigação, o qual se expressa ao abordarem-se os aspectos específicos da gestão dos RSD da comunidade, assim como as diversas propostas que neste sentido se têm realizado em busca de uma perfeição e transformação, a partir da sua natureza complexa.

\subsection{BJETIVO}

O presente capítulo teve como objetivo apresentar elementos para elaborar as diretrizes de um modelo de estratégia visando a integração dos processos da gestão de resíduos sólidos domésticos da comunidade do entorno da Escola Superior Pedagógica do Bié, em Angola, desde as instituições educativas.

\section{CARACTERIZAÇÃO DA REGIÃO ESTUDADA}

Angola possui uma área de $1.246 .700 \mathrm{~km}^{2}$, sendo o terceiro maior país da África sub-saariana. Esse país faz fronteira com a Namíbia, a Zâmbia, a República do Congo e a República Democrática do Congo (INE, 2018). A Tabela 1 apresenta alguns indicadores econômicos e sociais de Angola, baseados em informações de Banco Mundial (WDI, 2018), relativos a 2016.

Tabela 1. Indicadores econômicos e sociais de Angola, relativos a 2016.

\begin{tabular}{|c|c|}
\hline Indicador & Quantidade \\
\hline População (habitantes) & 28.813 .463 \\
\hline Densidade populacional (habitantes por $\mathrm{km}^{2}$ ) & 23,1 \\
\hline População vivendo no meio rural (\%) & 35,9 \\
\hline População vivendo no meio urbano (\%) & 64,1 \\
\hline População vivendo na capital Luanda (\%) & 39,0 \\
\hline População com acesso a eletricidade (\%) & 40,5 \\
\hline Consumo de energia elétrica (kWh per capita) & 312,5 \\
\hline Produto Interno Bruto (US\$) & $95.337 .203 .468,00$ \\
\hline Produto Interno Bruto per capita (US\$ per capita) & $3.308,77$ \\
\hline
\end{tabular}

O setor agrícola responde por $42 \%$ dos empregos em Angola, pois $92 \%$ do seu cultivo tem sido produzido pela agricultura familiar, destacando-se a cultura do milho, que ocupa cerca de 38\% da área agrícola do 
país, seguido da mandioca (15\% da área) e feijão (11\% da área) (RoA, 2019). Segundo essa mesma fonte governamental a agricultura, a pecuária e a silvicultura correspondem a 12\% do PIB nacional.

$\mathrm{Na}$ economia de Angola se destacam as exportações de petróleo e gás natural, as quais contribuem com mais de $50 \%$ do PIB, $70 \%$ da receita do governo e $90 \%$ das receitas de exportação. Por esse motivo, um dos principais problemas ambientais desse e de outros países africanos ricos em petróleo é o derramamento de óleo nos oceanos (Fayiga et al., 2018).

0 crescimento da população urbana tem sido um fenômeno observado na história recente de Angola. No período de 1960 a 2017, a porcentagem da população total vivendo nas cidades variou de 10,4\% para 64,8\% (WDI, 2018). Todavia, a maioria dos residentes urbanos desse país vive em áreas de baixa renda, nas quais geralmente há deficiência na oferta de diversos serviços essenciais, como água encanada, eletricidade, segurança, sistemas de coleta e tratamento de esgoto e resíduos sólidos (Mendelsohn, 2019).

As informações relacionadas a gestão dos resíduos sólidos domésticos em Angola são escassas, e a magnitude da contaminação no ambiente por tais resíduos não se encontra disponível (Mendelsohn, 2019). Luanda, capital e maior cidade de Angola, na qual vive 39\% da população do país, gera mais de 2 milhões de toneladas RSD por ano. A geração per capita de RSD na Província de Luanda alcançou, em 2012, uma média de $0,65 \mathrm{~kg} /$ (habitante.dia), variando de $0,30 \mathrm{~kg} /$ (habitante.dia) para os municípios suburbanos, até um máximo de $1,0 \mathrm{~kg} /$ (habitante.dia), na cidade de Luanda. Tais resíduos são dispostos, sem qualquer separação, no aterro Mulenvos, o maior do país (Maria et al., 2019).

No Plano Estratégico para a Gestão de Resíduos Urbanos em Angola, elaborado pelo Ministério do Ambiente, a geração per capita do país atingiu $0,46 \mathrm{~kg} /$ (habitante.dia), com uma projeção de crescimento a $0,81 \mathrm{~kg} /$ (habitante.dia) até 2025 , o que corresponderia a um total anual de 8,6 milhões de toneladas (PEGRU, 2012).

Impactos ambientais relacionados a gestão dos resíduos sólidos em Angola tem sido relatados na literatura científica, de maneira pontual e isolada, como as emissões de gases de efeito estufa no aterro de Mulenvos, em Luanda (Maria et al., 2019), carreamento de resíduos sólidos para o oceano Atlântico, gerados nas principais cidades costeiras, como Luanda, Benguela e Cabinda (Mendelsohn, 2019), e poluição da água superficial e subterrânea em Lubango (Silva et al., 2017).

0 território de Angola está dividido em 18 províncias, 164 municípios e 518 comunas e 44 distritos. A Província de Bié tem uma área de $70.314 \mathrm{~km}^{2}$, a $8^{\underline{a}}$ maior entre as províncias de Angola. Sua população atingiu 1.552.808 habitantes em 2016, o que correspondeu a uma densidade populacional de 22,1 habitantes $/ \mathrm{km}^{2}$ (INE, 2018). Essa província possui a terceira maior área agrícola de Angola, na qual se destaca a produção de milho, feijão, arroz e batata (RoA, 2019).

Nessa província está inserida a Escola Superior Pedagógica do Bié (ESPB) (Figura 1), uma instituição do Ensino Superior Pública criada em 2009, com a missão de desenvolver atividades de ensino, pesquisa e prestação de serviços à comunidade.

O campus da ESPB está situado na capital da Província de Bié, na cidade do Cuito, e conta com cerca de 1.500 estudantes de graduação, distribuídos em nove cursos, oferecidos pelo Departamento de Ciências da Educação (Educação Física e Desportos, Educação Pré-escolar, Educação Primária, Ensino da Psicologia); pelo Departamento de Ciências da Natureza (Ensino da Biologia, Ensino da Geografia, Ensino da Química), e pelo Departamento de Ciências Exatas (Matemática e Física) (ESPB, 2019).

Na Figura 1 é possível observar a inserção da ESPB em uma área urbanizada, o que deverá ser considerado na elaboração do diagnóstico da geração dos RSD nessa área.

Não se dispõe, até o momento, de levantamentos relacionados a caracterização e geração de resíduos sólidos domésticos nessa instituição, mas considerando a média de Luanda relatada por Maria et al. (2019) (0,65 kg/(habitante.dia)), esse valor pode atingir cerca de uma tonelada diária, no período escolar. Tal magnitude, associada a geração do entorno, emerge a necessidade de políticas para o enfrentamento dessa questão na abrangência universitária. 
Figura 1. Localização e entorno da Escola Superior Pedagógica do Bié, Cuito, Angola.

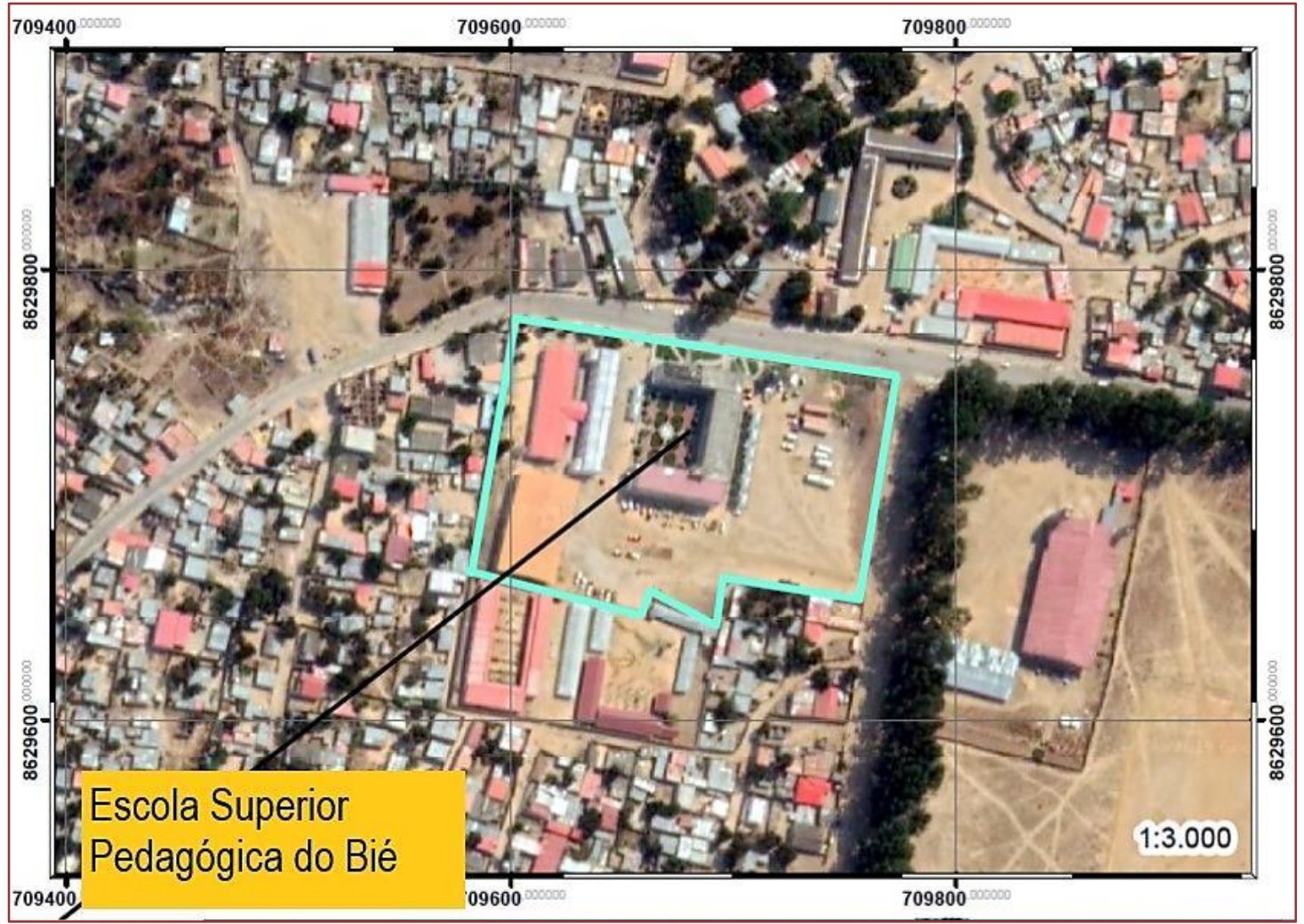

\section{DIRETRIZES PARA A EXTENSÃO UNIVERSITÁRIA VOLTADA A GESTÃO DOS RESÍDUOS SÓLIDOS GERADOS NA ESCOLA SUPERIOR PEDAGÓGICA DO BIÉ E EM SEU ENTORNO}

O aporte teórico principal consistiu na concepção e elaboração de um Modelo de estratégias que integre o tratamento da Educação Ambiental na gestão dos resíduos sólidos domésticos da comunidade, sustentado em enfoques, princípios e critérios básicos que permitem a determinação de níveis onde se expressam os nexos existentes entre os seus aspectos teóricos, metodológicos e práticos, para favorecer a transformação da realidade ambiental (Barros, 2012).

A significação prática consiste em um modelo de gestão de resíduos sólidos gerados pela comunidade, o que evidencia as etapas do seu desenvolvimento, ações educativas e ambientais integradoras, além de um programa de intervenção comunitária por vias formais e não formais.

Outros resultados importantes para o estabelecimento de diretrizes de extensão universitária para a comunidade do entorno da Escola Superior Pedagógica do Bié incluem:

- O estudo de diagnóstico da Educação Ambiental referentes a Gestão de resíduos orgânicos da comunidade "São José", no entorno ESPB, que serve de base para o conhecimento e caracterização da população, estudos posteriores e a tomada de decisões referente ao desenvolvimento de atitudes ambientais;

- A caracterização ambiental da comunidade "São José";

- Um conjunto de indicadores para medir a atitude ambiental do sujeito e para a caracterização gestão de resíduos orgânicos da comunidade, que serve de referência para a sua utilização desde o ponto de vista didático e ambiental;

- Conjunto de mapas que reflitam a integração dos componentes do Meio Ambiente Comunitário estudado e que sirvam de referência para a sua utilização desde o ponto de vista cartográfico, a interpretação ambiental e a integração de componentes. 
Aspectos da gestão dos resíduos sólidos domésticos no entorno da ESPB pode ser percebida por meio de levantamentos fotográficos recentes, e realizados em julho de 2019. Nesse registro fotográfico se evidencia a magnitude da problemática do lixo difuso, encontrado no entorno da ESPB e visualizado por meio da Figura 2. Nessa Figura se destaca o acúmulo de resíduos sólidos domésticos recicláveis, como papel, plástico e metal, os quais foram dispostos em terrenos próximo ao aterro controlado de Cuito e no entono da ESPB. Esses resíduos poderiam ter outra destinação, além de justificar uma ação pedagógica extendida ao entorno da universidade.

Figura 2. Aspecto geral da disposição do lixo difuso na região da Escola Superior Pedagógica do Bié, em Angola

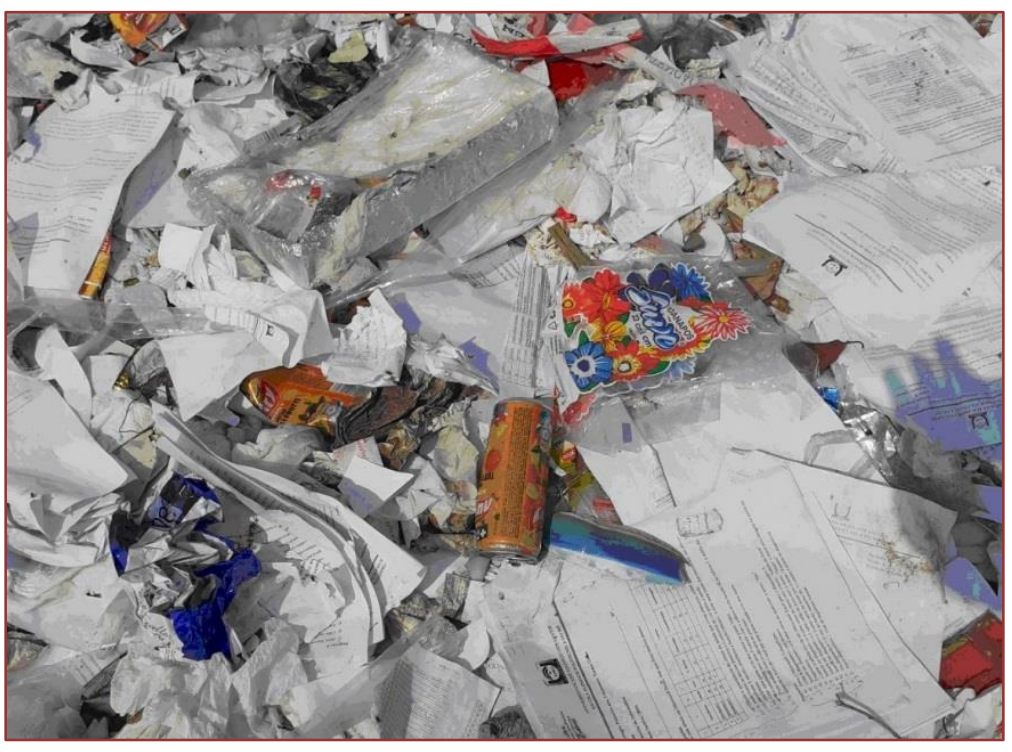

Outro aspecto relacionado a gestão dos resíduos sólidos pode ser observado na Figura 3. Essa Figura apresenta um container para depósito dos resíduos sólidos domésticos, sem qualquer separação, como também é praticado em Luanda, conforme relatado por Maria et al. (2019).

Figura 3. Depósitos de resíduos sólidos domésticos no entorno da Escola Superior Pedagógica do Bié, destacando-se a queima de resíduos sólidos pela comunidade do entorno.

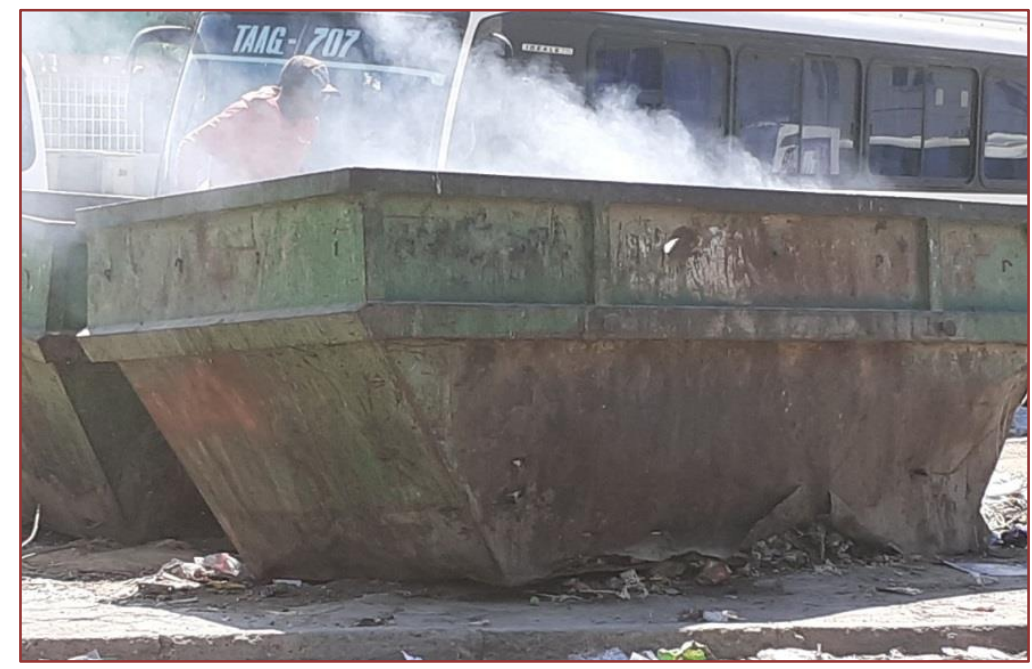

O recolhimento desses resíduos sólidos não é realizado diariamente pelo poder público municipal e, por esse motivo, a própria comunidade ateia fogo no lixo acumulado em tais depósitos, como está evidenciado 
na Figura 3. Portanto, tais aspectos registrados por meio de levantamento fotográfico nortearão ações pedagógicas e extensionistas que deverão ser priorizadas junto a comunidade do entorno da ESPB.

Um terceiro e importante aspecto que influenciará nas ações relacionadas a gestão dos resíduos sólidos domésticos da ESPB e de seu entorno, refere-se à ausência da indústria de reciclagem nessa região. Essa realidade também é observada na Amazônia brasileira, o que dificulta o estabelecimento de políticas que fomentem a logística reversa e a cadeia da reciclagem (Benone \& Medeiros, 2019)

Uma iniciativa para sistematizar as experiências sobre o tema se refere a oficinas de Educação Ambiental desenvolvidas na Escola Superior Pedagógica do Bié, em 2015 (Figura 4). Tais oficinas se propuseram a introduzir a dimensão ambiental como parte da formação integral da preparação do pessoal pedagógico.

As oficinas de Educação Ambiental impulsionaram o desenvolvimento da Educação Ambiental na comunidade entorno da ESPB, com numerosos aportes teóricos, metodológicos e práticos. Uma desses aportes práticos foi o Programa de embelezamento das Escolas, que consistiu na projeção de processos construtivos para elevar a qualidade estética e funcional. Tal programa permitiu a criação de espaços de ambientação que impliquem um melhoramento na qualidade de vida dos estudantes, trabalhadores e membros da comunidade, como a criação de jardins nas escolas e espaço baldios na comunidade.

Outro Programa de formação ambiental abordou a confecção e reparação de brinquedos. Esse Programa implicou na solução de problemas sociais e ambientais, pois a necessidade de brinquedos de baixo custo e alta qualidade educativa transmitem uma mensagem de proteção ao Meio Ambiente.

Um Encontro realizado entre professores e estudantes das escolas primárias incentivou a separação dos resíduos e o plantio de árvores nos arredores das escolas (Figura 5)

Figura 4. Oficinas de Educação Ambiental realizada na Escola Superior Pedagógica do Bié.

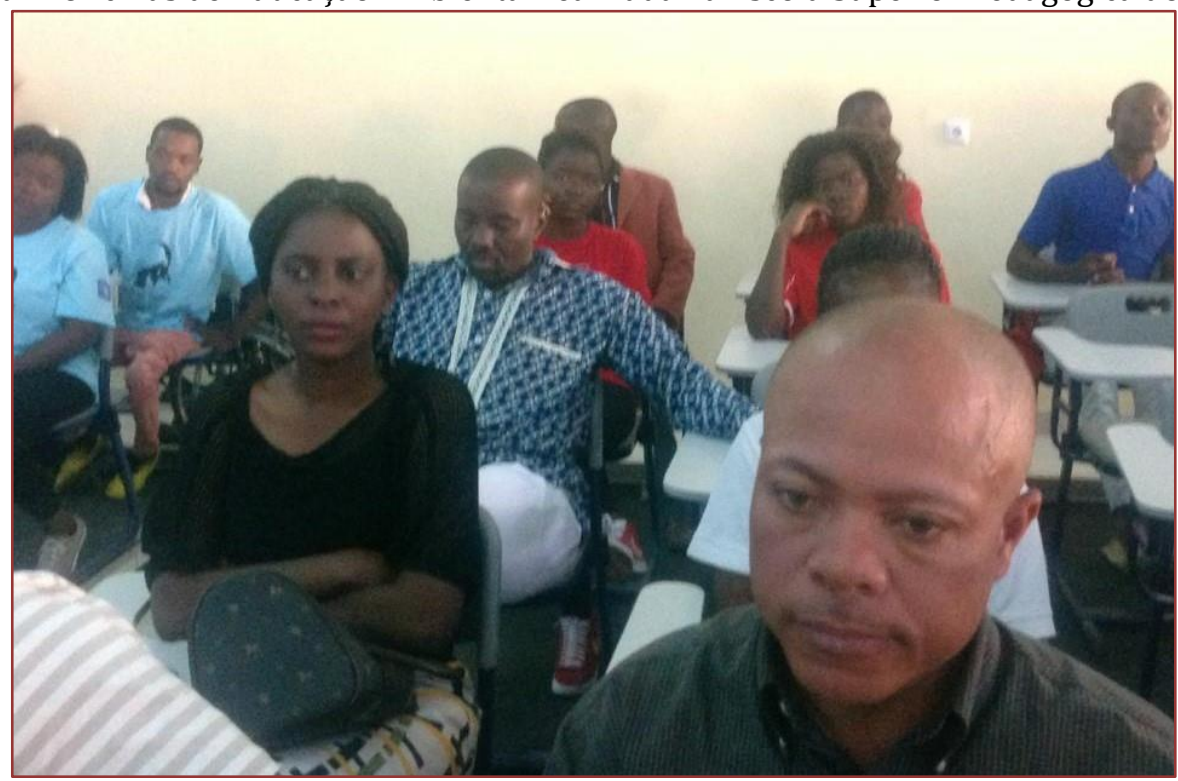


Figura 5. Encontro entre professores da Escola Superior Pedagógica do Bié (ESPB) e estudantes do ciclo primário: A) plantio de árvores no entorno da ESPB; B) separação de resíduos sólidos

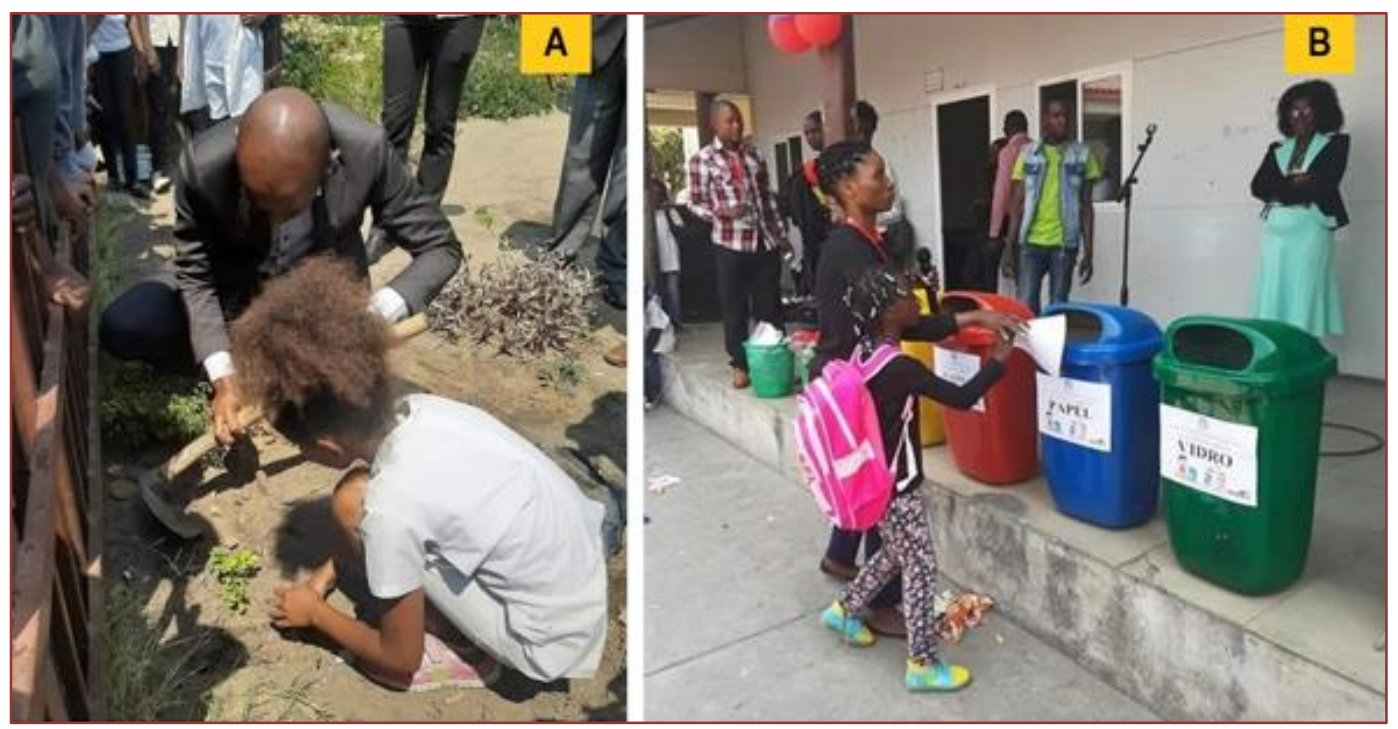

Todas estas atividades, realizadas no ano 2015, deram origem à Criação do Projeto de Educação Ambiental da Escola Superior Pedagógica do Bié. Além disso, pelas indagações relacionadas com o tratamento da problemática ambiental na comunidade entorno da Escola, pôde-se concluir que apesar dos esforços realizados nesta direção, ainda persistem limitações que tem inumeráveis manifestações nos resultados do trabalho das instituições educativas, referentes a:

- A falta de estratégias coerentes e sistemáticas que integrem os esforços das instituições de ensino na proteção do Meio Ambiente Comunitário;

- Inadequado tratamento da problemática ambiental com um caráter integral por parte das instituições educativas da comunidade entorno da Escola Superior Pedagógica do Bié

- 0 tratamento parcial, e em ocasiões isoladas, dos aspectos relacionados aos conhecimentos, a percepção e a sensibilidade da população perante os problemas do Meio Ambiente Comunitário;

- A concepção didática-metodológica para o tratamento dos problemas ambientais da comunidade a partir de um estudo de diagnóstico integral;

- Um enfoque disperso e parcializado para dirigir o processo de avaliação da Educação Ambiental da Comunidade;

- A insuficiente utilização de indicadores para avaliar a situação real do Meio Ambiente comunitário de uma maneira integrada.

\section{CONSIDERAÇÕES FINAIS}

Contemporaneidade Sócio-Ambiental do Tema: o modelo se baseia num enfoque integrador para enfrentar a gestão de resíduos orgânicos da comunidade, contribuindo para solucionar os aspectos contemplados nos documentos normativos, potencializar as relações das instituições educativas e chegar a um melhor conhecimento do Meio Ambiente Comunitário, dos seus componentes e das suas relações essenciais.

Relevância no Contexto Pedagógico: se expressa num modelo de estratégia que desde a sua concepção integradora para o tratamento da Gestão de resíduos orgânicos da comunidade contribui para reduzir as insuficiências que se manifestam no processo educativo que desenvolvem as instituições educativas da comunidade. 


\section{RECOMENDAÇÕES PARA AVANÇOS FUTUROS}

- Aprofundar os estudos teóricos dos antecedentes da Educação Ambiental em Gestão de Resíduos Sólidos, como uma forma de contribuir para o desenvolvimento epistemológico da Educação Ambiental Comunitária.

- Aprofundar o desenvolvimento das etapas de evolução da Educação Ambiental Comunitária desde o ponto de vista teórico, pedagógico e metodológico, para contribuir para o desenvolvimento de uma didática da Educação Ambiental ainda em construção.

- Desenhar e executar programas de capacitação, formação e educação ambiental no âmbito comunitário, que sirva para os fins docentes, investigativos e de gestão comunitária das instituições de ensino.

\section{REFERÊNCIAS}

[1] Barros, R.T.V. Elementos de gestão de resíduos sólidos. Belo Horizonte: Tessitura Editora, 2012. 59p.

[2] Caballero, J.L.L. Estratégia de Educação Ambiental como base para o desenvolvimento do Trabalho Comunitario. Ciudad de La Habana, Cuba: Isph, 2001. 60p.

[3] Caluhongue, G.M. A educação ambiental na formação inicial do professor de geografia na Escola Superior Pedagógica do Bié. Via Clara, Cuba: Editora Pueblo Educación Mined, 2015. 100p.

[4] Carlos, G. Estratégia para a educação ambiental nos estudantes da carreira de geografia na Escola Superior Pedagógica do Bié na República de Angola. Porto, Portugal: Porto Editora, 2015. 94p.

[5] Citma Cuba medio ambiente y desarrollo sostenible a 10 años de la Cumbre de Rio de Janeiro. Rio =+10. Ciudad de La Habana, Cuba: Editora Pueblo Educación Mined, 2002. 89p.

[6] Espb Escola Superior Pedagógica do Bié. Histórico da entidade. Cuito, 2019. Disponível em: http://www. https://espbie.ed.ao/. Acesso em: 27 nov. 2019.

[7] Fayiga, A.O., Ipinmoroti, M.O., Chirenje, T. Environmental pollution in África. Environment, Development and Sustainability, v. 20, p.41-73, 2018.

[8] Follari, R. La interdisciplina en la educación ambiental. Tópicos en Educación Ambiental, v. 1, n. 2, p. 27-35, 1999.

[9] Ine Instituto Nacional de Estatística; 2016. Anuário de estatísticas sociais: dados de 2011-2016. Luanda: Ine, 2018. 135p.

[10] Maria, C., Góis, J., Leitão, A. Challenges and perspectives of greenhouse gases emissions from municipal solid waste management in Angola. Energy Reports, 2019. (prelo)

[11] Mc Pherson, M. Didáctica para el estudio de la Comunidad y su Medio Ambiente. Ciudad de La Habana, Cuba: Editora Pueblo Educación Mined, 2002a. 65p.

[12] Mc Pherson, M. La educación ambiental em la enseñanza de las ciencias. Ciudad de La Habana, Cuba: Editora Pueblo Educación Mined, 2002b. 70p.

[13] Mendelsohn J.M. Landscape Changes in Angola. In: Huntley B., Russo V., Lages F., Ferrand N. (eds) Biodiversity of Angola. Springer, Cham, 2019. p. 123-137.

[14] Oliveira, B.O.S., Medeiros, G.A. Evolução e desafios no gerenciamento dos resíduos sólidos urbanos nos estados da região norte, Brasil. Revista Valore, v. 4, n. 1, p.749-761, 2019.

[15] Pegrsu Plano estratégico de gestão dos residuos urbanos. Luanda, Angola: Ministério do Ambiente, 2012. 93p.

[16] RoA República de Angola. Desenvolvimento sustentável da agricultura, pecuária, setores afins e agrosilvicultura. Luanda: Ministério da Economia e Planejamento, 2019. 333p.

[17] Sánchez, B., Fabiola, E. Apuntes sobre medio ambiente. Ciudad de La Habana, Cuba: Ispejv. Dpto. Geografía. 1998. 22p.

[18] Silva, M.M.V.G., Gomes, E.M.C., Isaías, M., Azevedo, J.M.M., Zeferino, B. Spatial and seasonal variations of surface and groundwater quality in a fast-growing city: Lubango, Angola. Environmental Earth Sciences, v. 76, p.1-17, 2017.

[19] Valdés, O. Como desarrollar la educación ambiental en las escuelas rurales. Ciudad de La Habana, Cuba: Editora Pueblo Educación Mined, 2011. 70p.

[20] Wdi World development indicators. 2018. World Bank Group, Washington. https://datacatalog.worldbank.org/dataset/world-development-indicators. Acesso em: 25 jul. 2019 


\section{Capítulo 9}

\section{Transformação de resíduos de mineração em materiais de construção - Estudo exploratório de abordagens}

\section{Mônica da Cunha e Silva \\ Isabella Machado de Almeida}

Resumo: A redução da geração de resíduos das atividades extrativistas, como a mineração e fabricação de materiais de construção, é um dos temas adotados pela agenda da sustentabilidade. Objetivo: A proposta desse trabalho é investigar as produções acadêmicas para embasar a compatibilidade entre essas duas atividades econômicas para a produção de esforços votados à redução da geração de resíduos. Metodologia: Os conceitos de resíduo zero (Zero Waste) e de Simbiose Industrial (Industrial Simbiosys) são apresentados para fomentar a discussão da possibilidade da integração entre as atividades econômicas objeto desse estudo, bem como materiais acadêmicos abordando uso de resíduos da construção civil, gestão e reaproveitamento de resíduos de mineração. Resultados: A preocupação com a redução da geração de resíduos é presente tanto na indústria da construção civil como na mineração. Resíduos inertes da mineração são compatíveis com as necessidades de materiais de construção. Concluiu-se que a compatibilidade de volumes gerados e características dos insumos demandados com os ofertados tornam os estudos empregando resíduos de mineração na construção civil um campo oportuno para estudos para o desenvolvimento de atividades sinérgicas entre as atividades estudadas.

Palavras Chave: Resíduos de mineração, Construção Civil, Simbiose Industrial. 


\section{INTRODUÇÃO}

A construção civil é apontada como um setor que consome quantidades vultuosas de recursos naturais e energia, cuja maioria dos materiais é extraída do solo, de tal modo que a exploração desses recursos causam problemas ambientais significativos. Além disso, os impactos com transporte de matérias primas naturais são crescentes, uma vez que os centros consumidores estão ficando cada vez mais distantes dos locais de obtenção dos recursos necessários à indústria da construção civil (VENKATARAMA REDDY et al., 2016). Uma alternativa para a redução dos impactos mencionados é o uso de resíduos de outras atividades como matéria prima para essa indústria, podendo ser o caso dos rejeitos inertes da mineração, pois ambas atividades se encontram na mesma escala de consumo de recursos naturais e geração de impactos ambientais (YELLISHETTY et al., 2008). Estudos envolvendo a produção de materiais de construção com resíduos em geral apresentam um volume chamativo de produção (MURMU; PATEL, 2018), incluindo estudos empregando resíduos da mineração (AZNAR-SÁNCHEZ et al., 2018). A compatibilidade entre a oferta de resíduo de uma atividade, que passa a ser material demandado por outra é fator decisório na escolha de alternativas produtivas envolvendo a simbiose industrial (CHERTOW, 2000).

Portanto, o estado de Minas Gerais, por exemplo, apresenta um cenário propício para esse tipo de sinergia entre os setores produtivos mencionados. Visto que, os locais de exploração mineral encontram-se próximos aos centros urbanos, cujo crescimento populacional costuma ser impulsionado pela implantação de empresas de setor ou relacionadas a ela. Essa transferência de população, para atender à empresa instalada, costuma acompanhar uma aceleração da construção civil especialmente a habitacional. Sendo assim, o objetivo desse trabalho é trazer os estudos envolvendo o desenvolvimento de materiais de construção fabricados com resíduos da mineração abordando as questões da economia circular: a simbiose industrial e a política de resíduo zero.

\section{METODOLOGIA}

Para embasar a discussão sobre estratégias envolvendo a redução de impactos ambientais gerados pelas atividades de mineração e construção civil, foi realizada busca por artigos abordando possibilidades de estratégias corporativas voltadas para a sustentabilidade. Também foram realizadas buscas por trabalhos acadêmicos abordando o emprego de resíduos na fabricação de artefatos de construção civil e gestão sustentável de resíduos na mineração. Da literatura obtida, foram selecionados os artigos de autores com relevância para a definição dos conceitos de Simbiose Industrial e Resíduo Zero e, para a discussão acerca da produção científica, artigos de revisão bibliográfica recentes e relevantes.

\section{RESULTADOS E DISCUSSÃO}

Nos artigos selecionados foram encontradas citações a Zaman (2015) para os assuntos relativos à redução da geração de resíduos (zero waste management) e a Chertow (2000) para a definição de simbiose industrial. Dois artigos com revisão bibliográfica robusta foram incluídos nesse estudo, o primeiro abordando a produção de blocos de construção sustentáveis (MURMU; PATEL, 2018) e o segundo discutindo a gestão sustentável de resíduos de mineração (AZNAR-SÁNCHEZ et al., 2018). Também foi selecionado um estudo de caso (YELLISHETTY et al., 2008) e outro discutindo a pesquisa e desenvolvimento de produtos de alvenaria com resíduos sólidos não orgânicos (VENKATARAMA REDDY et al., 2016) - ambos na Índia - e uma tese de doutorado para exemplificar a aplicação no contexto nacional.

O conceito de simbiose industrial descreve a relação sinérgica entre duas ou mais indústrias, envolvendo intercâmbio de recursos (materiais e energia, por exemplo), de maneira mutuamente benéfica em que os benefícios coletivos são maiores que a soma dos benefícios individuais, assim, gerando oportunidades de negócios economicamente atraentes e ambientalmente benéficas (CHERTOW, 2000). Já a gestão para a geração de zero resíduo parte da ecoefetividade para atingir ao máximo da ecoeficiência (ZAMAN, 2015). A eco efetividade trata da busca pelo desenvolvimento de atividades de ciclo completamente fechado, com total retroalimentação e sem necessidade de extração de recursos naturais e deposição de resíduos, já a eco eficiência é um modelo mais adequado às relações de consumo atuais, na qual se busca reduzir o impacto e diminuir os custos das atividades já existentes (BRAUNGART; MCDONOUGH; BOLLINGER, 2007). 
No artigo de revisão de bibliografia sobre a produção de blocos de construção sustentáveis foram levantados 43 artigos usando resíduos dos quais apenas 8 são originários das atividades de mineração, o que chama a atenção é o uso desses resíduos para a fabricação de diferentes tipos de blocos, tais como cerâmicos, autoclavados e estabilizados por compressão (MURMU; PATEL, 2018). 0 pouco uso de rejeitos de mineração na construção é confirmado no artigo levantamento de estudos sobre estratégias de gerenciamento em que se menciona a estratégia de reuso na gestão de resíduos, apesar da pouca menção a contribuições sociais e econômicas (AZNAR-SÁNCHEZ et al., 2018), confirmando o exposto por Zaman (2015).

A tese brasileira selecionada para essa discussão (ANDRADE, 2014) traz a caracterização dos rejeitos de mineração de ferro tanto in natura quanto separados visando sua aplicação na construção civil, as possibilidades de uso elencadas por sua autora são compatíveis com o exposto por Yellishetty et al. (2008) e Venkatarama Reddy et al.(2016) em que se afirma o potencial como substituto de agregados naturais, adição em concreto de alto desempenho e uso na produção de blocos cerâmicos e de terra crua. Além disso, a relevância do material nacional selecionado se dá pela demonstração da adequação das estratégias de construção sustentável ao contexto local, pois o problema do deslocamento das populações para os centros urbano, elevando a demanda por habitação e, consequentemente, materiais de construção precisa ser mitigado pela redução dos impactos gerados pela indústria da construção civil.

\section{CONSIDERAÇÕES FINAIS}

As leituras selecionadas permitiram o contato com os conceitos de simbiose industrial e de geração zero de resíduo, além do conhecimento do cenário da produção acadêmica voltado para a fabricação de produtos de construção que empregam resíduos da mineração. Também pôde-se inferir a presença de uma lacuna teórica abordando os aspectos econômicos e sociais das ações voltadas para 0 desenvolvimento sustentável das atividades da indústria da construção civil e da atividade de mineração, apesar da compatibilidade entre as necessidades técnicas como características físicas e químicas e a escala de produção.

As autoras esperam ter tornado possível aos leitores o contato com os conceitos pertinentes à economia ambiental e fornecido bibliografia para aprofundamento nos assuntos abordados, bem como divulgação oportunidades de pesquisas no setor da construção civil e sustentabilidade.

\section{REFERÊNCIAS}

[1] Andrade, L. C. R. de. (2014). Caracterização de rejeitos de mineração de ferro, in natura e segregados, para aplicação como material de construção civil (Universidade Federal de Viçosa). Retrieved from http://www.locus.ufv.br/handle/123456789/6664

[2] Aznar-Sánchez, J., García-Gómez, J., Velasco-Muñoz, J., \& Carretero-Gómez, A. (2018). Mining Waste and Its Sustainable Management: Advances in Worldwide Research. Minerals, 8(7), 284. https://doi.org/10.3390/min8070284

[3] Braungart, M.; Mcdonough, W.; Bollinger, A. Cradle-to-cradle design: creating healthy emissions-a strategy for eco-effective product and system design. Journal of cleaner production, v. 15, n. 13-14, p. 1337-1348, 2007.

[4] Chertow, M. R. (2000). Industrial Symbiosis: Literature and Taxonomy. Annual Review of Energy and the Environment, 25(1), 313-337. https://doi.org/10.1146/annurev.energy.25.1.313

[5] Murmu, A. L., \& Patel, A. (2018). Towards sustainable bricks production: An overview. Construction and Building Materials, 165, 112-125. https://doi.org/10.1016/j.conbuildmat.2018.01.038

[6] Venkatarama Reddy, B. V., Hemanth Kumar, H., Ullas, S. N., \& Gourav, K. (2016). Non-organic solid wastes potential resource for construction materials. Current Science. https://doi.org/10.18520/cs/v111/i12/1968-1976

[7] Yellishetty, M., Karpe, V., Reddy, E. H., Subhash, K. N., \& Ranjith, P. G. (2008). Reuse of iron ore mineral wastes in civil engineering constructions: A case study. Resources, Conservation and Recycling, 52(11), 1283-1289. https://doi.org/10.1016/j.resconrec.2008.07.007

[8] Zaman, A. U. (2015). A comprehensive review of the development of zero waste management: Lessons learned and guidelines. Journal of Cleaner Production, 91, 12-25. https://doi.org/10.1016/j.jclepro.2014.12.013 


\section{Capítulo 10}

Identificação das possíveis causas para o elevado índice de pós-obra em uma construtora certificada pela ABNT NBR ISO 9001 e SIAC: Um estudo de caso em obra de Condomínio Horizontal

\section{Taciane Strickler Dutra}

Resumo: De acordo com diversos referenciais, o índice de chamados de pós-obra nas edificações torna-se um dos principais fatores de insatisfação dos clientes sobre os imóveis construídos pelas empresas incorporadoras. Visando a melhoria contínua e a satisfação do cliente, as empresas precisam se adaptar, enquadrando-se em sistemas de gestão da qualidade (SGQ), com engajamento seus profissionais nos processos, planejando e gerenciando. 0 trabalho objetiva identificar os serviços de pós-obra que apresentam maiores demanda de reparos em um empreendimento residencial, rastreando os motivos da existência destas falhas e, posteriormente sugerir soluções de melhorias para a redução destes serviços no pós-obra. 0 estudo foi desenvolvido em uma obra de condomínio residencial horizontal, na cidade de Cachoeirinha/RS. A empresa dispõe pela ABNT NBR ISO 9001 e SiAC do PBQP-H. A partir do problema identificado foi definida a metodologia desenvolvendo fluxogramas metodológicos com base na revisão bibliográfica, a fim de identificar as causas do problema. A análise de dados foi explorada por meio dos documentos do SGQ da empresa e entrevistas com os funcionários e clientes do empreendimento. Contudo, foi possível observar que 51,85\% das casas entregues aos clientes, no período em estudo, necessitaram de reparos pelo pós-obra. Do total de reparos, verificou-se que 49\% eram representados por apenas quatro serviços (vazamentos da rede hidráulica, tubulações obstruídas na rede hidrossanitária, pisos cerâmicos ocos e/ou quebrados e o funcionamento inadequado da rede elétrica), enquanto os outros 51\% eram compostos por 14 serviços. Logo, foram rastreados os quatro serviços com maior demanda, mapeando seus processos, desde a execução, até a verificação final, etapa que antecede a entrega do imóvel. Sendo assim, pode-se concluir que o problema analisado era pertinente a falhas no SGQ da empresa, ao gerenciar e abordar os documentos ao empreendimento, bem como os ciclos diários de inspeção, no qual apresentou um elevado índice de aprovação nos serviços (94,29\%), não levando em consideração os pontos críticos dos serviços executados. Acredita-se que com a revisão dos processos e a retificação dos documentos pertinentes aos serviços em estudo, seja minimizado o problema, aumentando a satisfação do cliente.

Palavras-Chave: construção civil, pós-obra, gerenciamento, sistema de gestão da qualidade. 


\section{INTRODUÇÃO}

A execução de um empreendimento, seja ele de qualquer tipologia e porte, é a junção de itens, que quando alinhados e engajados englobam-se numa perfeita constituição para a plena execução de uma obra. (MATTOS, 2010).

Lafetá (2013) relata que o atual cenário da construção civil mundial exalta a necessidade de se construir com qualidade, entregando aos seus usuários (clientes) imóveis com funcionalidade e terminabilidade. Segundo dados do SEBRAE (2014), os atuais empreendimentos estão à procura desta qualidade, desenvolvendo dia a dia técnicas de melhorias para se adequar aos requisitos dos seus clientes. 0 autor narra também que a tendência para esta mudança de postura se faz por meio de monitoramentos focados na qualidade dos serviços, inter-relacionando-os a todo o momento.

Segundo Rosa (2017), a satisfação do cliente é obtida por meio de um ciclo composto por: projetar, planejar, gerenciar, executar e conferir. 0 ciclo expresso pela autora faz referência ao ciclo do Plan Do Check Action (PDCA), uma elaborada ferramenta de gerenciamento segundo a Associação Brasileira de Norma Técnicas (ABNT). (ABNT, 2015).

A ABNT (2015) descreve que uma maneira eficaz de controlar processos visando à qualidade do produto e a satisfação do cliente, seja realizada por meio de certificações do sistema de gestão da qualidade (SGQ). Mundialmente, qualquer produto ou serviço deve seguir processos padronizados, atingindo requisitos necessários. A Organização Internacional de Normalização (ISO) 9000 é um exemplo de certificação mundial, garantindo que a empresa entregue padrões de qualidade aos clientes. (ROSA, 2017).

De acordo com a Câmara Brasileira da Indústria da Construção Civil (CBIC) na última década a indústria da construção civil brasileira cresce em escala majoritária devido às retificações impostas nas normas técnicas de projeto, execução e garantia. (CBIC, 2013).

Além da certificação da ABNT Norma Brasileira de Regulamentação (NBR) ISO 9001 as construções nacionais devem seguir os padrões de qualidade do Programa Brasileiro de Qualidade e Produtividade do Habitat (PBQP-H) do Sistema de Avaliação da Conformidade de Serviços e Obras (SiAC). (ROSA, 2017). Entretanto, mesmo com as boas condutas expostas pelas certificações, ainda existem fatores que impactam na satisfação dos clientes perante suas edificações, principalmente com os serviços de pós-obra. (CBIC, 2013).

De acordo com Mattos (2010), o sólido planejamento e gerenciamento são um dos conceitos para se atingir o sucesso na construção de um empreendimento. Junto a este conceito estão anexas as características de conhecimento pleno da obra, detecção das situações desfavoráveis, agilidade nas decisões, padronização, documentações e rastreabilidades, referências de metas e criação de dados históricos.

Para Meseguer (1991) a solução para reduzir os chamados de pós-obras nas edificações é embasar os processos executivos de forma que sejam todos inter-relacionados, assegurando maior qualidade ao produto.

\subsection{BJETIVOS}

0 presente trabalho tem por finalidade identificar os serviços de pós-obra que apresentam maiores demanda de reparos, em um empreendimento residencial, recém entregue aos clientes, rastreando os motivos da existência destas falhas, e posteriormente sugerir soluções de melhorias para a redução destes serviços no pós-obra. Desta forma, acredita-se que com melhorias nos processos do SGQ da empresa possa se minimizar estes problemas.

Como objetivos específicos o trabalho propõe:

a) identificar os serviços de pós-obras com maior índice de chamados no setor de manutenção;

b) observar a forma com que a construtora atende a exigência dos requisitos da norma ABNT NBR ISO 9001 e SiAC para os serviços identificados com maior demanda de reparos no pós-obra;

c) identificar os processos que estão inter-relacionados com os serviços apontados com maior demanda de reparos no pós-obra, identificando seus pontos críticos; 
d) analisar o impacto que o planejamento e o gerenciamento do empreendimento geram nos serviços identificados com maior demanda de reparos no pós-obra;

e) observar a satisfação do cliente sobre o imóvel recebido da empresa no empreendimento em estudo.

\section{METODOLOGIA}

A partir da figura 1 é possível verificar a metodologia utilizada neste estudo de caso.

Figura 1: Fluxograma metodológico do estudo de caso.

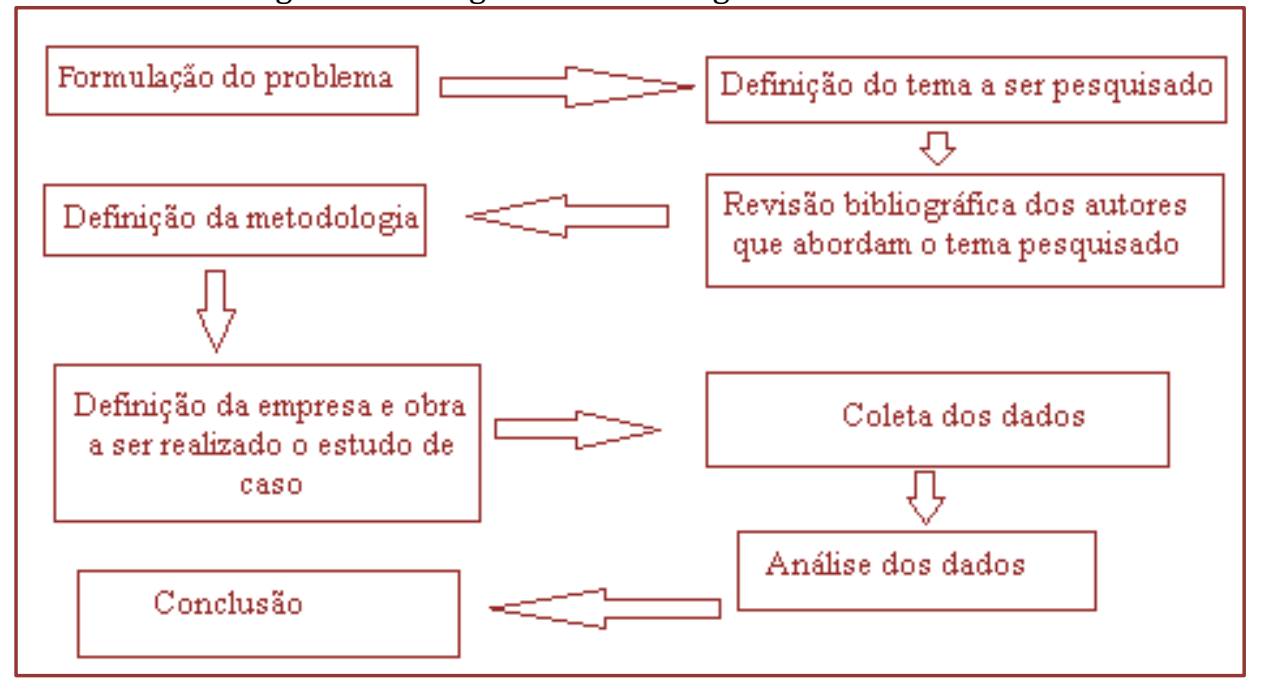

Fonte: Autor do Trabalho

Conforme a metodologia definida no fluxograma da figura 1, para o estudo de caso estabeleceu-se o seguinte problema: o elevado índice de reclamações dos clientes após receberem suas residências, gerando um grande volume de chamados no setor de pós-obra da empresa para realizar manutenção nas unidades habitacionais do empreendimento em estudo.

A definição do tema foi realizada a partir do empreendimento em estudo, composto por 416 unidades habitacionais horizontais, em que se percebeu que mesmo a construtora sendo certificada pelo regimento SiAC do programa da qualidade PBQP-H e a ABNT NBR ISO 9001, os problemas relacionados à qualidade dos imóveis afetavam a satisfação do cliente.

Para determinar o número de incidência de casos foi realizada uma análise da empresa, bem como o empreendimento em estudo, conforme descrito a seguir.

- Características da Empresa

A empresa situa-se na cidade de Porto Alegre/RS, sede administrativa, com canteiros de obras nas cidades de Cachoeirinha/RS e Canoas/RS. Atuante no ramo de edificações unifamiliares, a empresa está no mercado gaúcho há 45 anos. A grande maioria dos empreendimentos é destinada às pessoas de baixa renda, participantes do programa brasileiro Minha Casa, Minha Vida (MCMV).

O SGQ da empresa é certificado pela ABNT NBR ISO 9001, revisão 2015, e o SiAC 2017 em nível A, do PBQP-H. Sabe-se que o regimento passou por nova revisão, em junho de 2018. Porém, a empresa possui um prazo de até junho de 2019 para adaptar-se aos novos requisitos. Contudo, estas interferências não serão levadas em consideração neste estudo de caso.

O SGQ da empresa é coordenado pela equipe do setor da qualidade e abrange todos os setores da empresa. A equipe é formada por três profissionais com a responsabilidade de implantar, promover e monitorar o $\mathrm{SGQ}$, assegurando que todos os requisitos sejam atendidos conforme as normas vigentes. 
Empreendimento (objeto) de Estudo

0 objeto de estudo desta pesquisa foi um condomínio residencial de baixo padrão, com unidades habitacionais horizontais. 0 empreendimento é formado por 416 casas, divididas em onze módulos. Os módulos são referência para a fase de entrega das unidades.

As casas possuem três modelos arquitetônicos, sendo, com 1 dormitório, 2 dormitórios e para portadores de necessidades especiais (PNE). Para o estudo de caso, as unidades foram generalizadas como um único modelo, não intervindo nos resultados que serão apresentados. A obra teve início em abril de 2016 e previsão de término para setembro de 2018, totalizando o período de 29 meses.

O enfoque deste estudo foi nos módulos I, II, III e IV compondo 108 unidades habitacionais entregues aos clientes, e na maioria, já com habitantes nas unidades. Foi decidido analisar as habitações entregues aos clientes nos meses de maio, junho e julho do ano de 2018. A escolha destes meses ocorreu devido ao começo das entregas das casas aos clientes, possibilitando o estudo e prevenindo problemas do gênero nas futuras unidades.

A coleta dos dados foi realizada através dos documentos do SGA e entrevistas com os clientes do empreendimento e alguns funcionários da empresa. A análise de dados foi realizada conforme o quadro 1, a partir das habitações entregues aos clientes nos meses de maio, junho e julho do ano de 2018.

Quadro 1: Relação de dados coletados.

\begin{tabular}{|c|c|}
\hline Fonte & Dados coletados \\
\hline $\begin{array}{l}\text { Documentos } \\
\text { do SGQ }\end{array}$ & $\begin{array}{l}\text { - Índices de Chamados do Pós-obra } \\
\text { - Instrução de Trabalho da Engenharia de Instalação Hidrossanitária (IT.ENG.015) - anexo A } \\
\text { - Instrução de Trabalho da Engenharia de Instalação Elétrica (IT.ENG.014) - anexo B } \\
\text { - Instrução de Trabalho da Engenharia de Revestimento Cerâmico (IT.ENG.017) - anexo C } \\
\text { - Formulário da Engenharia de Inspeção de Serviços Contratados (FM.ENG.016) - anexo D } \\
\text { - Índices de conformidade dos serviços do FM.ENG.016 } \\
\text { - Formulário da Engenharia de Checklist: Revisão das Unidades (FM.ENG.020) - anexo E } \\
\text { - Índices de conformidade dos serviços do FM.ENG.020 - Anexo F } \\
\text { - Formulário da Engenharia de Cronograma Físico-Financeiro (FM.ENG.014) - anexo G } \\
\text { - Cronograma de Médio Prazo } \\
\text { - Fluxograma de Serviços do Empreendimento - anexo H }\end{array}$ \\
\hline Entrevistas & $\begin{array}{l}\text { - Entrevista 01: Coordenador de Obras da Empresa - apêndice A } \\
\text { - Entrevista 02: Engenheiro Pós-obra - apêndice B } \\
\text { - Entrevistas } 03 \text { a 33: Clientes do Empreendimento do estudo de caso }\end{array}$ \\
\hline
\end{tabular}

Fonte: Autor do Trabalho.

Os indicadores de conformidade dos serviços, tanto do FM.ENG.016, como do FM.ENG.020, foram calculados a partir da contagem do total de itens a serem inspecionados, gerando a porcentagem total de serviços (100\%), e da contagem do total de serviços aprovados para as casas em análises, gerando uma porcentagem de serviços aprovados. Sequencialmente foi obtido o total de serviços reprovados, e a porcentagem total de serviços reprovados.

As entrevistas 01 e 02, realizada com o Engenheiro Coordenador de Obras e o Engenheiro do Pós-Obra sequencialmente, não seguiu nenhum modelo específico. As perguntas foram realizadas no entorno do tema da pesquisa apartir de uma conversa da autora com os entrevistados, conforme pode ser visto nos apêndices A e B deste trabalho. 
As entrevistas de 03 a 33, realizadas com os clientes do empreendimento do estudo de caso ocorreram por meio da seguinte pergunta: "O que você achou da casa entregue pela construtora, analisando tanto o interior da residência, como o exterior (terreno) e o bairro?" Após ter as repostas, de cada um dos 30 clientes entrevistados, a autora concluiu a satisfação dos mesmos como bom ou ruim. A classificação ocorreu de acordo com a interpretação da própria autora sobre as respostas.

\section{RESULTADOS}

A partir dos dados coletados, através dos documentos e entrevistas, conforme citado no quadro 1, foram realizadas as seguintes análises e obtidos os seguintes resultados.

- Índice de chamados de pós-obra

No período determinado para o estudo de caso (meses de maio, junho e julho do ano de 2018) foi analisado o documento do SGQ referente aos serviços de pós-obra, nominado Índice de Chamado do PósObra, e o total de casas entregues do empreendimento. A análise entre o número de casas entregues e o número de chamados de pós-obra pode ser vista na figura 2.

Figura 2: Gráfico comparativo entre o número de casas entregues x chamados de pós-obra nas casas entregues.

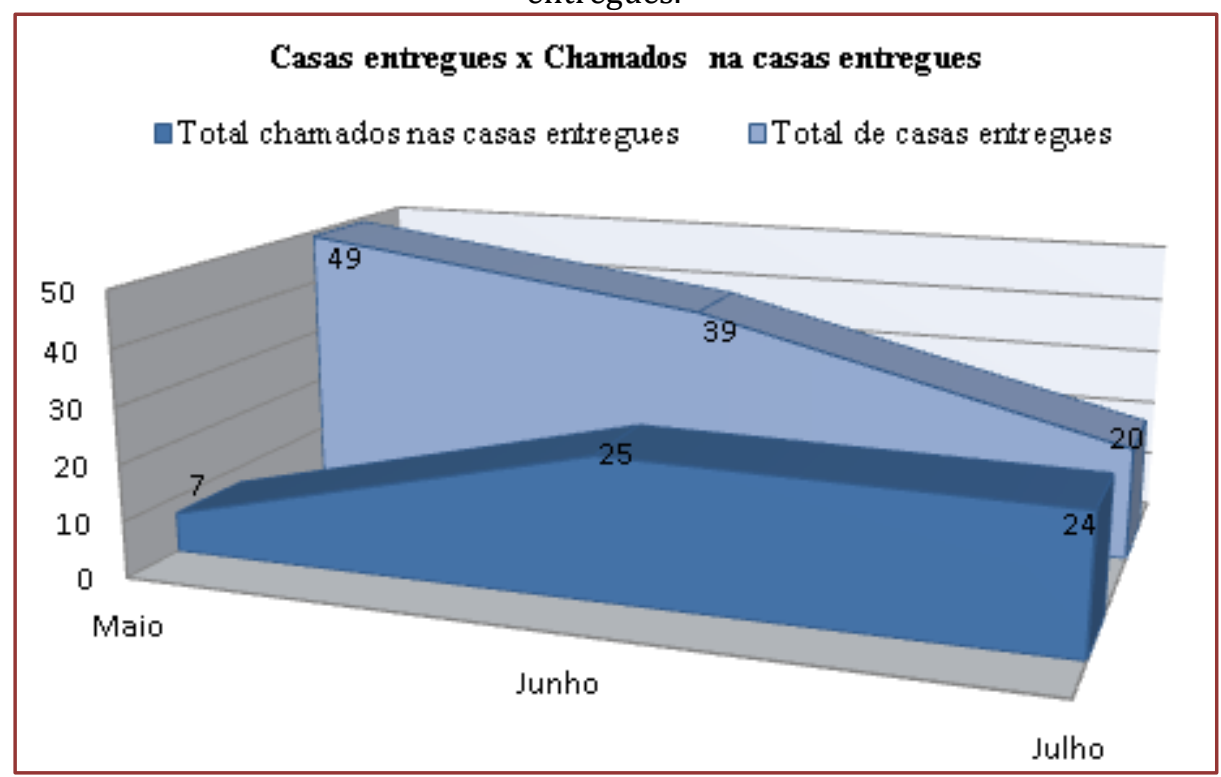

Fonte: Autor do Trabalho.

A partir do dado coletado pode-se identificar que, no decorrer dos meses, o total de casas entregues foi diminuindo (49 em maio, 39 em junho e 20 em julho), enquanto o total de chamados no setor de pós-obra aumentou ( 7 em maio, 25 em junho e 24 em julho). A figura 3 mostra o total de casas entregues e o total de chamados de pós-obra para as unidades entregues. 
Figura 3: Gráfico total de casas entregues e o total de chamados do pós-obra.

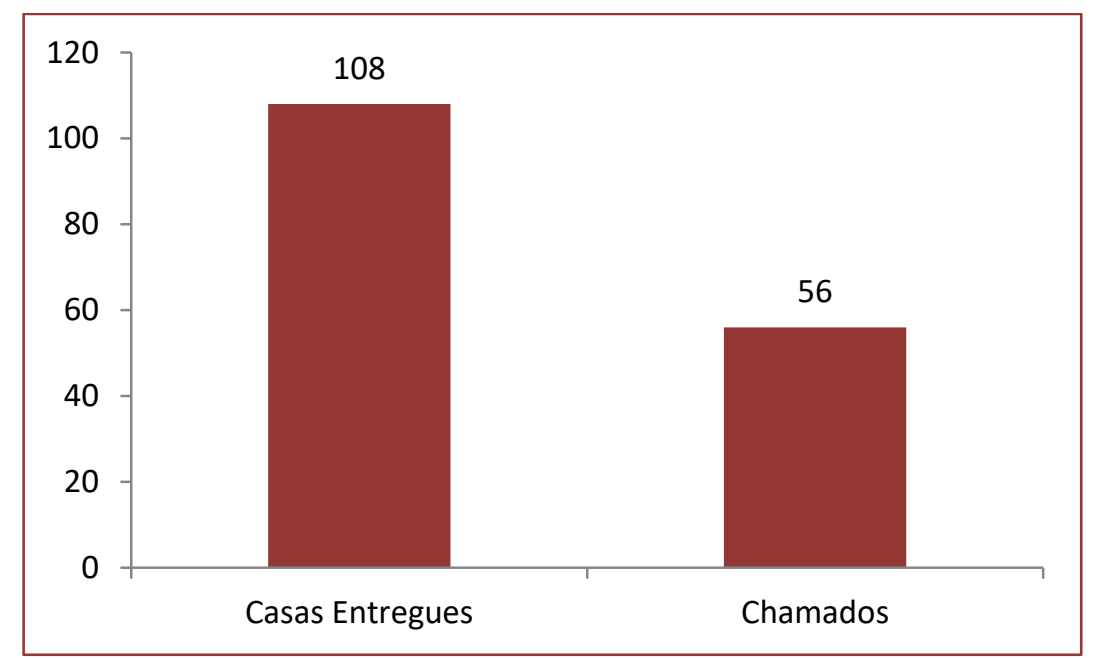

Fonte: Autor do Trabalho.

A partir da figura 3 pode-se observar que $51,85 \%$ das casas entregues abriram chamados junto ao setor do pós-obra devido a necessidade de manutenção nas casas. Na figura 4 é apresentada a porcentagem de chamados correspondente de cada mês do período em estudo. Analisando os dados da figura 4 percebe-se que os valores encontrados entre os meses de maio e junho sofreu um aumento significativo. Já, observando os valores entre os meses de junho e julho nota-se uma proximidade dos mesmos.

Após ser observado o índice de chamados por mês, junto ao setor de pós-obra da empresa, foram coletados quais os defeitos causadores destes chamados. A coleta ocorreu através da classificação do tipo de defeito por parte da empresa, e o mesmo foi seguido para este trabalho.

De posse da classificação dos defeitos dos chamados de pós-obra foi contabilizado o total de cada defeito por mês, e sequencialmente calculado a incidência da frequência de cada defeito. Sequencialmente, foi montando o gráfico, ilustrado na figura 5, no qual foram mantidos os defeitos com maiores porcentagens de incidência, totalizando em quatro defeitos correspondentes a 48,91\% dos chamados. Os demais 14 defeitos foram representados de uma única forma e denominados como outros, somando $51,09 \%$ dos chamados.

Figura 4: Gráfico índice de chamados de pós-obra.

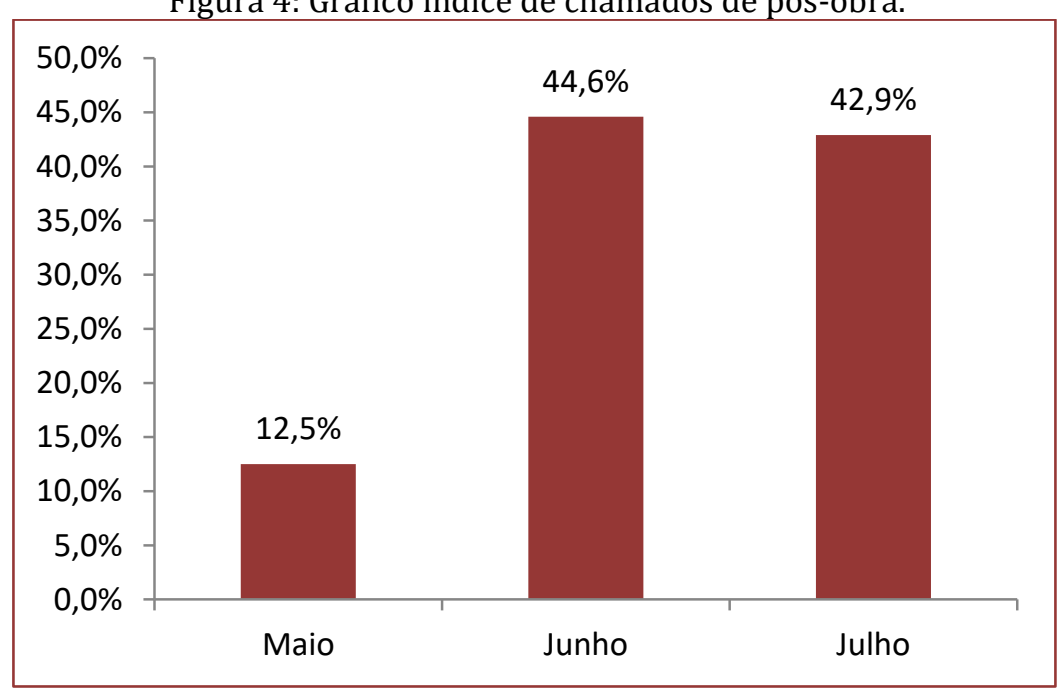

Fonte: Autor do Trabalho 
Figura 5: Gráfico Representação das porcentagens dos serviços no período em estudo.

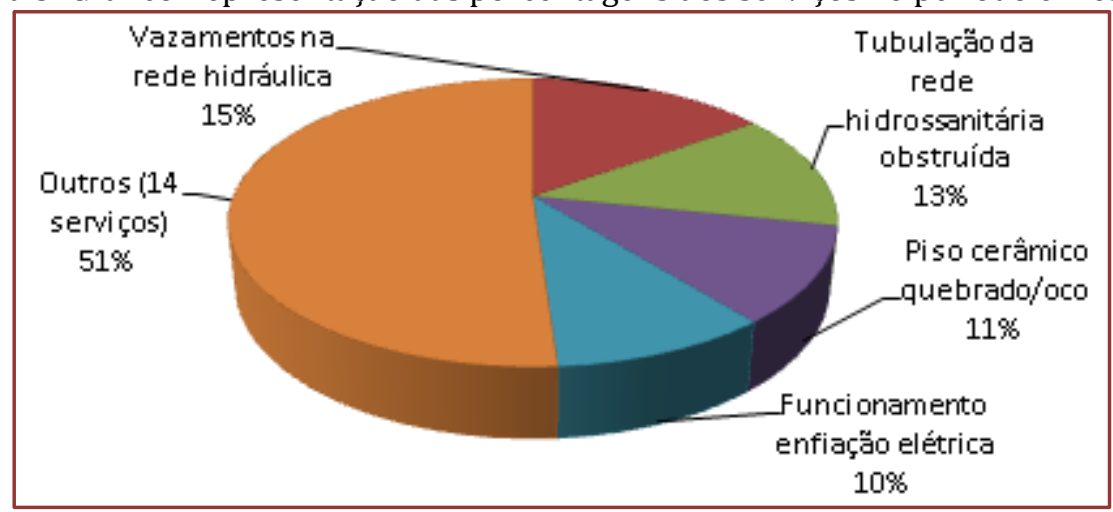

Fonte: Autor do Trabalho.

Baseado na figura 5 é notório que dos 14 serviços causadores dos chamados no pós-obras, apenas quatro representam quase a metade do total dos chamados (49\%). Logo, entende-se que o ponto crítico do índice de chamados do pós-obra encontra-se nesta parcela dos defeitos.

\section{- Instruções de Trabalho da Engenharia (IT.ENG)}

As Instruções de Trabalho da Engenharia (IT.ENG) são documentos do SGQ da empresa para todos os canteiros de obras e tipologias de obra, sendo acordado por todo o corpo técnico da empresa. Sendo assim, a IT.ENG é validada para todos os empreendimentos da empresa, assim como o Formulário da Engenharia de Inspeção de Serviços Contratados (FM.ENG.016) que apresentam serviços que podem ou não ser aplicados ao canteiro. Logo, foram analisados os dados pertinentes a estes serviços, incluindo seus procedimentos de execução, verificação, planejamento e gerenciamento.

Os procedimentos Instrução de Trabalho da Engenharia de Instalação Hidrossanitária (IT.ENG.015) são divididos para duas situações: tubulações da rede de esgoto e tubulações da rede de hidráulica. As tubulações da rede de esgotos dividem-se em novas duas situações: fundações com viga de baldrame e fundações com radier. Ambas relatam o passo a passo para execução do serviço, de acordo com as especificações de projeto de cada edificação. No empreendimento do estudo de caso, as fundações são do tipo radier, logo, atentou-se nesta instrução para o excesso de informações.

Os critérios de avaliação dos serviços da Instrução de Trabalho da Engenharia de Instalação Elétrica (IT.ENG.014) levam em consideração os parâmetros de limpeza, terminalidade e isolamento, sendo todos com tolerâncias visuais, não empregando nenhum teste específico de qualidade, o que implica em outro ponto crítico para o estudo de caso.

As Instrução de Trabalho da Engenharia de Revestimento Cerâmico (IT.ENG.017), assim como a IT.ENG.014, leva em consideração os parâmetros de medição e visuais para a conferência do serviço, porém não aplica nenhum teste de conferência para a execução do serviço.

\section{- Formulário da Engenharia de Inspeção de Serviços Contratados (FM.ENG.016)}

O Formulário da Engenharia de Inspeção de Serviços Contratados (FM.ENG.016) é um documento de conferência dos serviços executados nas obras, elaborado pelo setor da qualidade e o corpo técnico da empresa, integrando o SGQ. 0 mesmo é genérico para todos os empreendimentos, apresentando serviços que podem ou não ser aplicados a tal canteiro, ou seja, no estudo de caso existem diversos serviços não aplicáveis (NA).

As seções dos processos de execução que compreendem o FM.ENG.016 demonstram a tendência da ordem sequencial dos serviços a serem executados nas obras. Entretanto, é identificado que alguns itens estão localizados com posição diferente da apresentada na sequência da obra do estudo de caso, o que compromete o inter-relacionamento do SGQ. Outra análise importante sobre o formulário é quanto ao ciclo diário que o mesmo impõe sobre a obra, conforme a figura 6. 
Figura 6: Ciclo diário de inspeção dos serviços executados.

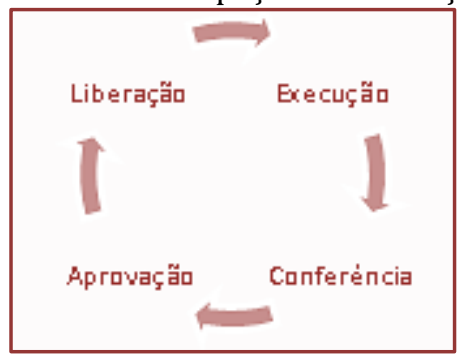

Fonte: Autor do Trabalho.

Entende-se que o tal serviço está concluído e apto, entretanto, ao se executar uma nova atividade sobre o mesmo, há uma grande hipótese de se danificar o que até então estava pronto. Assim sendo, com o ciclo adotado, este dano que surge passa a ser despercebido até a conclusão do imóvel, tornando-se visível apenas com o uso do cliente.

\section{" I Índice de Conformidades de Serviços do FM.ENG.016}

Foram realizados 6.480 inspeções nos serviços executados, das quais 6.110 foram aprovados (A) $(94,29 \%)$ e 370 reprovados (R) $(5,71 \%)$, o que demonstra um cuidado mais elevado dos profissionais ao executarem as atividades, em prol da qualidade das casas, assim como problemas neste processo, visto que durante o processo de vistoria de alguns reparos são realizados imediatamente, não sendo registrado o problema (R) no FM.ENG.016. Assim sendo, há divergência nos dados obtidos no formulário, pois o indicador de conformidades calculado seria menor do que o apresentado.

\section{- Formulário da Engenharia de Checklist: Revisão das Unidades (FM.ENG.020)}

Posterior à inspeção e aprovação dos serviços é realizado uma verificação final anterior a entrega do imóvel para o cliente. Para tal é preenchido o Formulário da Engenharia de Checklist: Revisão das Unidades (FM.ENG.020), formulário este genérico a todos os empreendimentos, logo, trás em seu corpo itens NA ao estudo de caso.

\section{- I I Indice de Conformidades de Serviços do FM.ENG.020}

Foram realizadas 9.317 inspeções finais nos imóveis, das quais somente 7,97\% dos itens foram R. Logo, torna-se visível a diferença de valores, atentando para falhas deste processo. Viu-se que o índice de conformidade dos serviços do FM.ENG.016 (94,29\%) e o índice de conformidade nos serviços do FM.ENG.020 (92,03\%) obtiveram percentuais próximos.

\section{- $\quad$ Planejamento do Empreendimento em Estudo}

0 planejamento do empreendimento é realizado a partir dos planejamentos de longo e médio prazo. 0 preenchimento do percentual realizado não apresentou vínculo com o FM.ENG.016 nem com a FM.ENG.020, registrando somente o que foi realizado, desconsiderando os documentos de inspeção.

Para o planejamento de longo prazo, nos meses em análise foi possível verificar as porcentagens previstas $(12,7 \%)$ e as porcentagens realizadas $(8,66 \%)$ para todas as atividades existentes no FM.ENG.014. Estas distorções de valores ocorreram devido a uma área do empreendimento isolada por questões de segurança dos funcionários (perigo de deslizamento de solo), impossibilitando o trabalho em tal local. Em contrapartida, ao se observar as porcentagens de acumulado previsto $(95,43 \%)$ e acumulado realizado $(94,83 \%)$ percebe-se que as distorções dos valores de porcentagem eram de apenas $0,6 \%$. Esta diferença procedeu-se por conta do adiantamento dos serviços anterior ao problema de deslizamento de solo. Contundo, afirma-se que se não tivesse acontecido este fato, o planejamento previsto, para cada mês, do empreendimento seria próximo ao executado.

O planejamento de médio prazo, para os mesmos meses em análise, foi previsto um total de 1389 atividades, porém foram executadas apenas 1186 atividades, resultando em 85,38\% de atividades 
executadas. Pode-se observar que o percentual atingido no planejamento de longo prazo, nos meses em estudo, foi de $68,19 \%$, enquanto no planejamento de médio prazo o percentual atingido foi de $85,38 \%$. Esta diferença pode ocorrer devido ao planejamento de longo prazo verificar o percentual físico-financeiro e o planejamento de médio prazo em número de atividades. Observa-se também que o índice de conformidade de serviço do FM.ENG.016 foi de 94,29\%, o que não impactou no FM.ENG.014.

\section{- Fluxograma de Serviços do Empreendimento em Estudo}

O fluxograma de serviços do empreendimento é elaborado com base na ferramenta de gerenciamento just in time, conforme informação do SGQ da empresa, delimitando o intervalo de tempo em que cada serviço deve ser executado nas casas. Porém, notou-se que as etapas construtivas são separadas, existindo um intervalo em que um serviço poderá ou não ser executado. As linhas de interligação dos serviços demonstram o momento em que o mesmo é concluído, devendo ser conferido, e posteriormente liberando a execução do serviço sucessor, ou indicando o seu retrabalho. Porém, esta ferramenta não apresenta os tempos necessários para a continuidade do fluxograma, podendo existir espaços de tempo entre as atividades devido somente a sua indicação de sequência.

\section{- Atendimento aos requisitos da ABNT NBR ISO 9001 e SiAC}

Como já visto a empresa e o canteiro de obras do estudo de caso possuem certificações pela ABNT NBR ISO 9001 e SiAC. Desta forma atentou-se para verificar se a empresa atendia realmente os requisitos exigidos. Foi possível afirmar que todos os requisitos eram atendidos, e que assim sendo, não impactavam no problema em questão.

\section{- Entrevista 01: Coordenador de Obras da Empresa}

Analisando a entrevista 01, realizada com o entrevistado 01, foi possível notar que há uma grande divergência entre os empreendimentos da empresa quanto à qualidade, custo e material empregado nas construções. Entretanto para a composição dos custos do orçamento não são levados em consideração estas divergências. Outro ponto que despertou atenção, ao realizar a análise, é quanto a não existência de fatores sólidos para a elaboração dos custos do pós-obra. Um custo em algum momento da empresa foi adotado pelos funcionários do setor e assim procede-se.

Quanto ao gerenciamento do empreendimento em estudo foi notado que o corpo técnico situado no canteiro de obras apresenta postura diferente dos profissionais do setor da qualidade. Fica claro que a empresa possui dois grandes grupos de profissionais que trabalham por único objetivo (entregar casas com qualidade aos clientes), o grupo da sede e o grupo da obra. Esta separação faz com que a troca de informações e visões dos próprios profissionais seja delimitada.

\section{- Entrevista 02: Engenheiro do Pós-Obra}

A partir da entrevista 02 realizada com o Engenheiro do pós-obra (entrevistado 02) foi visto que os procedimentos do setor de pós-obra são realizados de maneira simples, no qual existem poucas informações documentadas, impossibilitando análises elaboradas sobre as manutenções e retroalimentação do setor para implantação de melhorias.

\section{- Entrevistas 03 a 33: Clientes do Empreendimento da Empresa em Estudo}

As entrevistas do tipo três foram realizadas com 30 clientes do empreendimento em estudo, no momento em que os mesmos recebiam da empresa a chave de suas casas. A pergunta realizada pelo pesquisador aos clientes era a seguinte:

"O que você achou da casa entregue pela construtora, analisando tanto o interior da residência, como o exterior (terreno) e o bairro?". As 30 respostas obtidas foram analisadas pela autora, obtendo-se uma classificação da reposta como bom ou ruim. Para a análise foram levadas em considerações todas as argumentações e falas dos entrevistados. 
De posse da classificação, foram contabilizadas as classificações de bom e ruim, obtendo-se então 19 respostas para bom (63\%) e 11 repostas para ruim (37\%). Com os resultados, foi possível elaborar o gráfico expresso na figura 7, demonstrando a porcentagem de satisfação versus a porcentagem de insatisfação dos clientes.

Figura 7: Gráfico de porcentagem de satisfação x Porcentagem de insatisfação dos clientes

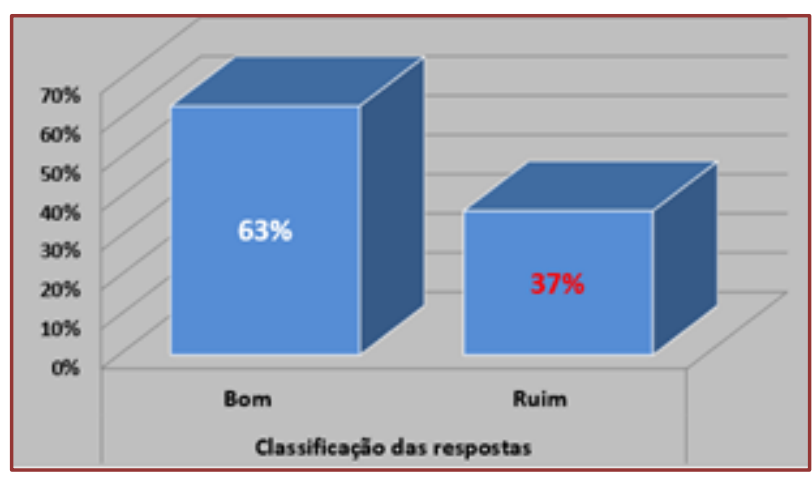

Fonte: Autor do Trabalho.

- Sugestões de Melhorias

Através das análises realizadas, foi possível se atentar para pontos críticos nos processos, sendo assim, são sugeridas melhorias aos mesmos.

Analisando o FM.ENG.016 e o fluxograma de serviços do empreendimento em estudo, foi verificado a sequência desordenada para a inspeção dos serviços, dificultando o processo para os profissionais conferentes. Sendo assim, sugere-se a aplicação de um novo ciclo diário de conferência, conforme a figura 8.

Figura 8: Novo ciclo diário para inspeção dos serviços executados.

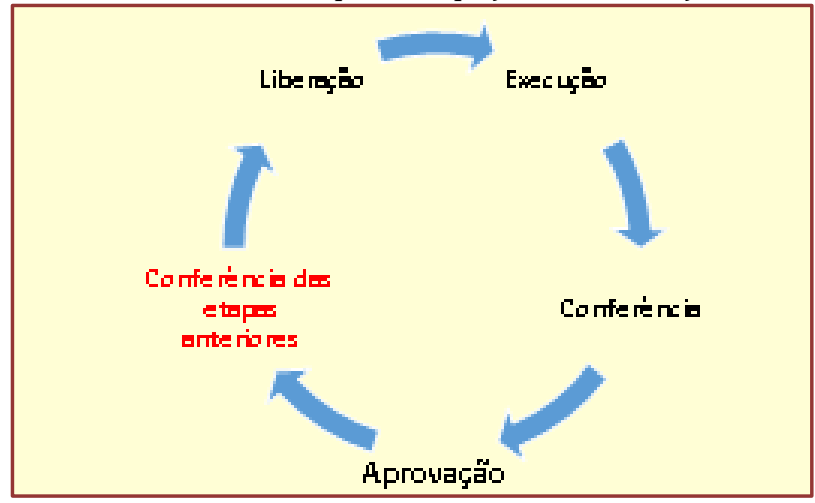

Fonte: Autor do Trabalho.

Já, ao analisar o FM.ENG.020 atentou-se que o mesmo tem caráter de inspeção visual, e não da aplicação de testes para conferências, conforme a expectativa do SGQ da empresa. Logo, a sugestão da autora, para os quatro serviços em análise no estudo de caso é que sejam aplicados testes de verificação junto ao escopo do FM.ENG.016, sendo eles:

a) vazamentos na rede hidráulica: incluir junto aos itens da rede hidráulica a conferência do enchimento da caixa d'água, com o tempo de 48 h de espera até que seja possível visualizar vazamentos nos casos de existência;

b) tubulações hidráulicas obstruídas: inclusão de testes de pressão nas tubulações hidrossanitárias com bombas hidráulicas;

c) pisos cerâmicos quebrados e/ou ocos: adicionar o teste de batidas da nas placas cerâmicas, confirmando sua aderência ao substrato; 
d) funcionamento da enfiação elétrica: incluir testes energizados com geradores de energia elétrica, reproduzindo o efeito de entrada de energia pelo poste particular de cada imóvel.

Através da entrevista 01 notou-se a falta de inter-relacionamento entre os profissionais da empresa, acarretando também em falhas dos processos. Logo, se sugere um novo fluxograma hierárquico para a locação dos funcionários, conforme a figura 9. Estima-se que com o novo modelo organizacional torna-se mais plausível o desenvolvimento de melhorias do próprio SGQ, visando os aspectos pertinentes de cada empreendimento, estimulando no dia a dia a busca pela melhoria contínua.

Figura 9: Fluxograma organizacional atual x fluxograma organizacional sugerido.

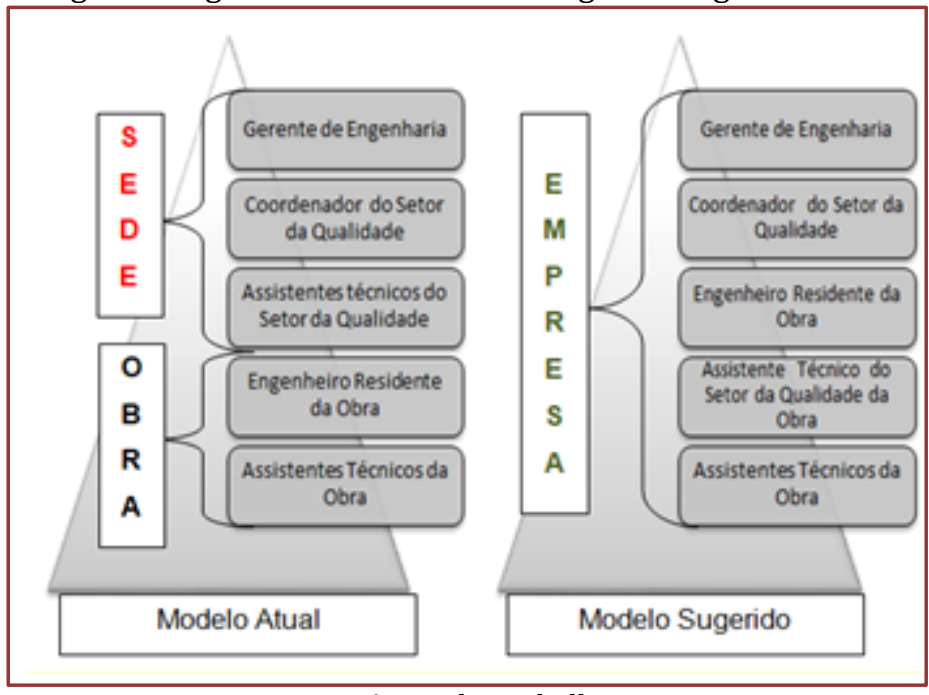

Fonte: Autor do Trabalho.

\section{CONCLUSÕES}

No estudo de caso desenvolvido, notou-se que mesmo a construtora tendo certificações nas normas ABNT NBR ISO 9001 e SiAC do PBQP-H, existem falhas associadas ao seu SGQ, intervindo no resultado dos processos do empreendimento. Mediante estas constatações, concluiu-se que o elevado índice de chamados no setor de pós-obra está diretamente relacionada a falhas nos processos construtivos.

A partir dos dados coletados e analisados foi possível concluir que $51,85 \%$ das casas entregues necessitaram de reparos pelo pós-obra. Destes chamados de pós-obra, $49 \%$ dos defeitos eram representados por apenas quatro serviços: vazamentos na rede hidráulica, tubulações obstruídas, pisos cerâmicos quebrados e o funcionamento da enfiação elétrica. Todos esses chamados implicam diretamente em custos para a empresa, geração de resíduos e insatisfação do cliente.

Com base nos documentos analisados percebeu-se que os mesmos têm caráter genérico, o que também impacta negativamente no controle de aprovação e/ou reprovação dos serviços a serem inspecionados. Desta forma, viu-se que o índice de serviços aprovados é de 94,29\% no FM.ENG.016 e 92,03\% para o FM.ENG.020. Ou seja, o alto índice de aprovação é devido à incompatibilização ou falta de itens a serem controlados.

Não houveram variações significativas em relação ao planejamento, porém pode-se observar que não estão relacionadas as verificações dos serviços ou empreendimento. Sugere-se que o planejamento e as verificações estejam relacionados bem como a implantação de um novo planejamento semanal com reuniões periódicas para o acompanhamento do empreendimento.

Com base nas análises das entrevistas 01 e 02, viu-se que a empresa possui dificuldades em elaborar informações consistentes para o setor de pós-obra. A falta de rastreabilidade e informações no setor é um ponto crítico para a tomada de decisões e melhorias nos empreendimentos. A implantação de relatórios após o conserto das casas nos chamados seria uma solução para esta falta de registros.

Quanto à satisfação do cliente sobre o empreendimento em estudo, concluiu-se a partir das entrevistas de 03 a 33, que 63\% dos clientes, ao receberem a casa da construtora, apresentam satisfação sobre o imóvel, mas alegam insegurança quanto à possibilidade de surgirem defeitos com o uso. A empresa, a partir do 
SGQ, poderia aplicar uma pesquisa de satisfação do cliente no momento da entrega para o mesmo, podendo verificar como está se dando o processo de entrega dos imóveis.

Outra sugestão seria a inclusão de aplicação das inspeções dos serviços e de inspeção final do imóvel concomitante ao processo de construção das casas para que sejam obtidos resultados satisfatórios e auxilie de forma que possa propiciar aprendizado e melhoria contínua aos processos.

Além disso, é necessária uma revisão dos documentos pertinentes ao sistema de gestão da qualidade da empresa e o inter-relacionamento das atividades e profissionais.

\section{REFERÊNCIAS}

[1] Associação Brasileira de Normas Técnicas. NBR ISO 9001 - Sistemas de Gestão da Qualidade - Requisitos. Rio de Janeiro: ABNT, 2015.

[2] Bernardes, Mauricio Moreira e Silva. Planejamento e controle da produção para empresas de construção civil. Rio de Janeiro: LTC, 2010.

[3] CBIC, Câmara Brasileira da Indústria da Construção. Manual de uso, operação e manutenção das edificações: Orientações para construtores e incorporadoras. Brasília, DF: CBIC, 2013.

[4] Cupertino, Daniel da Cruz. Análise de solicitações de assistência técnica em empreendimentos residenciais como ferramenta de gestão. 2013. 167 f. Dissertação de Mestrado. (Programa de Pós-Graduação em Geotecnia, Estruturas e Construção Civil). Escola de Engenharia Civil da Universidade Federal de Goiás. Goiânia. 2013.

[5] Fantinatti, Pedro Augusto Pinheiro. Ações de gestão do conhecimento na construção civil: evidências a partir da assistência técnica de uma construtora. 2008. 149 f. Dissertação de Mestrado. Escola de Engenharia. Universidade Estadual de Campinas. Campinas. 2008.

[6] Lafetá, Lima Pedro. Planejamento e controle de obras: soluções contratuais para viabilização da introdução do planejamento em canteiros com atuação de empreiteiras. 2013. 81 f. Trabalho de Conclusão de Curso (Bacharel em Engenharia Civil) - Curso de Engenharia Civil, Centro Universitário de Brasília. Brasília, DF, 2013.

[7] Mattos, Dórea Aldo. Planejamento e Controle de Obras. São Paulo: PINI, 2010.

[8] Meseguer, Alvaro Garcia. Controle e garantia da qualidade na construção. Trad. Roberto José falcão Bauer, Antonio Carmona F , Paulo Roberto do Lago Helene, São Paulo: Sinduscon-SP/Projeto/PW, 1991.

[9] Moreira, R. S. Procedimentos Operacionais: Boas Práticas na Elaboração e Implantação em Obras. Universidade Federal do Rio de Janeiro, UFRJ. Rio de Janeiro, 2014.

Rosa, Vera. Formação de auditores internos. São Paulo: Versalit: assessoria empresarial, 2017. Documento fornecido pela empresa. 


\section{Capítulo 11}

Implantação de usina de reciclagem de resíduos da construção civil em Município de Médio Porte

\section{Alyson Rodrigues Amaral \\ Adriana Antunes Lopes \\ Alexandra Fátima saraiva Soares}

Resumo: A implantação de usinas de reciclagem de resíduos da construção civil (RCC) é um tema que vem ganhando ênfase em muitos estudos nos últimos anos devido, principalmente, ao grande percentual destes resíduos presente na massa total de resíduos sólidos gerados pelos municípios brasileiros e ao descarte incorreto no meio ambiente, que vem provocando diversos impactos negativos. 0 objetivo deste estudo foi verificar a viabilidade econômica para implantação de uma usina de reciclagem de RCC em Itumbiara - GO, visto que o município possui potencial e o RCC gerado não é tratado da forma correta, sendo destinado de maneira inadequada ao lixão municipal. Para adquirir informações relevantes para a implantação da usina foi realizado pesquisa bibliográfica e, também, coleta de dados qualitativos e quantitativos do RCC gerado pelo município, por meio de consulta à Prefeitura e de visita técnica ao lixão municipal. A partir dos resultados obtidos, foi considerada uma taxa de geração de cerca de 320 toneladas de RCC/dia, sendo a maior parte composta por resíduos pertencentes à classe A. Com base nas considerações realizadas neste estudo e no uso de alguns indicadores financeiros de viabilidade chegou-se a um Valor Presente Líquido (VPL) de + 5.478.822,08, a uma Taxa Interna de Retorno (TIR) de 103\% e a um Payback descontado de menos de dois anos, mostrando que o investimento na usina de reciclagem de RCC proposta é bastante viável economicamente.

Palavras-Chave: Resíduos da Construção Civil, Usina de reciclagem, Viabilidade econômica. 


\section{INTRODUÇÃO}

O setor da construção civil, além de consumir uma grande quantidade de recursos naturais como areia e pedra, também é responsável por gerar um número elevado de resíduos, podendo este valor, segundo Pinto (1999), atingir a faixa de 40 a $70 \%$ do total de resíduos sólidos urbanos produzidos em cidades brasileiras de grande e médio porte.

A disposição inadequada dos resíduos provenientes desse setor, podendo ser chamados de resíduos da construção e demolição (RCC) ou popularmente de entulhos, configura-se como uma realidade da maioria dos municípios brasileiros, sendo a falta de fiscalização, a falta de um local de disposição adequado e a falta de conscientização ambiental da população, que poderia ser melhorada por meio de políticas públicas, fatores relevantes para que isso ocorra. Segundo a resolução CONAMA (Conselho Nacional do Meio Ambiente) n 307/2002, os RCC não podem ser dispostos em locais como aterros de resíduos sólidos urbanos, áreas de "bota fora", encostas, corpos d’água, lotes vagos e áreas protegidas por Lei (Brasil, 2002). A partir do momento que esses resíduos são dispostos nesses locais, uma série de impactos negativos podem ocorrer tanto ao meio ambiente como à saúde pública, tendo como exemplos o assoreamento e contaminação de rios e córregos e a atração de vetores causadores de doenças como dengue, zika, febre amarela, entre outras. Além disso, a disposição inadequada do RCC também gera problemas de ordem econômica para o poder público, principalmente o municipal, que tem que destinar gastos para a remoção desse resíduo.

Em meio a essa situação, a reciclagem entra como uma tecnologia capaz de reeducar a população em seus hábitos, ajudando a minimizar os prejuízos, causados tanto ao meio ambiente quanto ao meio social, por meio da redução no uso de recursos naturais e da diminuição de resíduos descartados. A reciclagem de RCC é uma atividade com grande potencial, mas que ainda não é amplamente difundida no Brasil. Começou a ganhar força a partir da publicação da CONAMA 307/2002, por meio da qual os geradores passaram a ter uma responsabilidade sobre seus resíduos. 0 tema foi reforçado, posteriormente, pela Lei 12.305/2010 (Brasil, 2010), que institui a Política Nacional de Resíduos Sólidos (PNRS). Apoiado nisso, a implantação de usinas de reciclagem de RCC passou a ter uma maior viabilidade, tanto econômica quanto ambiental, resultando no crescimento da taxa/ano de usinas instaladas no país. Segundo a Associação Brasileira para Reciclagem de Resíduos da Construção e Demolição (Abrecon, 2015), existem pelo menos 310 usinas em todo o país.

O município de Itumbiara-GO, localizado ao sul do estado de Goiás, na divisa com o estado de Minas Gerais, possui um grande potencial para a instalação de uma usina de RCC, visto ser um município de médio porte em que a taxa de geração de resíduos é relativamente alta. Além disso, segundo Helou (2016), a sua forte diversificação econômica e seu forte crescimento nas últimas décadas por conta da industrialização da região, chama a atenção de vários empreendedores na busca pela instalação de novos negócios. Já quanto ao gerenciamento dos resíduos, o município deixa a desejar, pois ainda não possui um Plano Municipal de Gerenciamento Integrado de Resíduos Sólidos (PMGIRS) e nem mesmo um local apropriado para dispôlos, encaminhando esses resíduos para uma área de disposição inadequada. Em vista disso, a implementação de uma usina de reciclagem de RCC se apresenta como uma medida mitigadora para os problemas relacionados ao descarte inadequado dos RCC e do uso excessivo de recursos naturais, além de contribuir para que o município se adeque à legislação e tenha uma nova visão sobre negócios que envolvam a reciclagem de resíduos.

\section{OBJETIVOS}

O presente estudo teve como objetivo geral verificar a viabilidade econômica para a implantação de uma usina de reciclagem de Resíduos da Construção Civil no município de Itumbiara - GO. Como objetivos específicos: levantar a quantidade de Resíduos da Construção Civil gerada no município, verificar e analisar os custos de implantação e operação da usina de RCC proposta e analisar os resultados, a fim de verificar a viabilidade econômica para a implantação da mesma. 


\section{METODOLOGIA}

Para o levantamento de dados e informações relevantes sobre usinas de reciclagem de RCC foi realizada pesquisa bibliográfica em monografias, dissertações, teses, sites, órgãos públicos, revistas e artigos científicos.

Com o objetivo de obter informações a respeito de dados qualitativos e quantitativos do RCC gerado e coletado pelo município, foi realizada consulta ao órgão público (Prefeitura de Itumbiara - GO) e também visita técnica na área de disposição final de resíduos sólidos.

A fim de verificar a viabilidade econômica de uma usina de RCC no município de Itumbiara-GO, foram adotados alguns procedimentos. Foi pré-definido a instalação de uma usina do tipo fixa que irá produzir agregados reciclados com diferentes granulometrias, sendo: areia, brita 0 (pedrisco), brita 1 e rachão. A partir disso, também foram pré-definidos os equipamentos e máquinas que farão parte da usina, sendo:

- - Um (1) conjunto de equipamentos para britagem novo: alimentador vibratório, britador, peneira vibratória, correias transportadoras e íman magnético;

- - Uma (1) balança para pesagem de caminhões nova;

- - Duas (2) pás carregadeira seminovas para espalhar material e alimentar o britador.

Para a instalação da usina foram considerados os seguintes custos iniciais:

- - A compra e instalação de equipamentos;

- - A compra de balanças e máquinas;

- Obras civis.

0 custo com o terreno foi desconsiderado, considerando que o mesmo será doado pela prefeitura sob forma de concessão. 0 tamanho do terreno foi determinado com base na capacidade de produção da usina, conforme sugerido por Jadovski (2005).

Para determinar o custo dos equipamentos de britagem, foi realizado um orçamento em três empresas, baseado na quantidade de resíduos classe A do município e nos equipamentos pré-definidos. Para determinar o custo da balança, também foram consultadas três empresas diferentes. Tanto para os equipamentos de britagem como para a balança, foi escolhido o orçamento de menor valor. Já o custo das pás carregadeira seminovas foi estabelecido com base em uma pesquisa em sites de anunciantes. Foi definido um preço médio baseado em máquinas de no máximo três anos de uso.

Em relação às obras civis, foi considerado necessária a construção de um muro ao redor da área, de uma guarita, de um escritório e de uma área de vivência com banheiros, vestiários e local para refeição e descanso. Além destes, também foi considerado o custo com a arborização em volta da área. Para determinar os custos das obras civis, com exceção do muro e da arborização, foi considerado o valor de $70 \%$ do Custo Unitário Básico (CUB) (Jadovski, 2005). Foi utilizado o CUB de Goiás, referente ao mês de setembro de 2017, que foi de 1.291,51/m² (SINDUSCON - GO, 2017). Em relação ao muro, foi estimado um valor de $71,00 / \mathrm{m}^{2}$ de muro construído (Casa Dicas, 2014). Já para a arborização no entorno da área, foram adotadas mudas a cada um metro, conforme sugerido por Stolz (2008). Quanto ao custo com a arborização, o mesmo foi desconsiderado, considerando que as mudas também serão doadas pela prefeitura, já que existem viveiros municipais.

Para a operação e manutenção da usina de RCC, dentre os custos, foram considerados:

- - Insumos de produção (água, energia e combustível);

- - EPIs (equipamentos de proteção individual);

- - Manutenção dos equipamentos de britagem;

- - Mão de obra (funcionários);

- - Vigilância.

O número de funcionários para a parte de produção foi determinado com base na capacidade de produção da usina (Jadovski, 2005). Além destes, também foi considerado necessário para o funcionamento da usina mais dois (2) funcionários, sendo: um (1) engenheiro responsável pela usina e um (1) responsável pela portaria e balança. 
O custo mensal com água foi determinado por meio da Equação 1, estabelecida por Jadovski (2005), por meio da qual se leva em consideração a capacidade de produção da usina (CP), o valor unitário da água $/ \mathrm{m}^{3}$ (VU) e um coeficiente de consumo no valor de 0,08 .

$$
\text { Custo mensal }=\mathrm{CP} \times 0,08 \times \mathrm{VU}
$$

O custo da energia também foi estabelecido, conforme Jadovski (2005). Foi considerada a potência dos equipamentos instalados em função da capacidade de produção da usina e do tipo de agregado que será produzido (Tabela 1).

Tabela 1. Potência dos equipamentos. Fonte: JADOVSKI, 2005, adaptado.

\begin{tabular}{c|c|c|c|c|c|c|}
$\begin{array}{c}\text { Capacidade de } \\
\text { Produção }\end{array}$ & $\begin{array}{c}\text { Alimentador } \\
\text { Vibratório }\end{array}$ & $\begin{array}{c}\text { Britador } \\
\text { de Mandíbulas }\end{array}$ & $\begin{array}{c}\text { Britador de } \\
\text { Impacto }\end{array}$ & Peneiras & \multicolumn{2}{c|}{$\begin{array}{c}\text { Torreias } \\
\text { Transportadoras } \\
\text { Bica } \\
\text { Corrida }\end{array}$} \\
$\begin{array}{c}\text { Tonelada/h } \\
\text { Areia e } \\
\text { Brita }\end{array}$ \\
\hline 20 & 2,94 & 19,61 & 22,07 & 3,68 & 2,94 & 11,03 \\
\hline 30 & 3,79 & 19,42 & 29,42 & 5,52 & 2,94 & 13,24 \\
\hline 40 & 3,79 & 35,00 & 36,78 & 7,36 & 3,68 & 13,24 \\
\hline 50 & 5,51 & 42,00 & 44,13 & 9,20 & 4,41 & 26,48 \\
\hline 75 & 11,03 & 58,00 & 73,55 & 11,03 & 9,19 & 27,58 \\
\hline 100 & 14,71 & 75,00 & 110,00 & 12,86 & 11,03 & 30,16 \\
\hline
\end{tabular}

Para determinar o preço unitário da água, da energia e do combustível, foram consultados os valores cobrados no município de Itumbiara - GO, referentes ao mês de setembro de 2017. Os EPIs necessários, assim como o período de troca (Tabela 2), também foi baseado em Jadovski (2005).

Tabela 2. Equipamentos de Proteção Individual (EPIs) e período de troca. Fonte: Jadovski, 2005.

\begin{tabular}{|l|c|}
\multicolumn{1}{c|}{ EPIs } & $\begin{array}{c}\text { Período de } \\
\text { troca (mês) }\end{array}$ \\
\hline Calça & 6 \\
\hline Jaleco & 6 \\
\hline Camiseta & 3 \\
\hline Botina & 6 \\
\hline Luvas & 3 \\
\hline Capacete & 12 \\
\hline Óculos & 6 \\
\hline Protetor auricular & 1 \\
\hline
\end{tabular}

O preço dos EPIs foi determinado por meio de uma consulta a empresas de Itumbiara - GO. Para estabelecer os custos com manutenção e desgaste dos equipamentos foi utilizada uma taxa anual de 3\% do valor do investimento inicial, conforme adotado por Manfrinato, Esguícero e Martins (2008).

O custo com mão de obra foi resumido aos salários dos funcionários. Os salários mensais para os cargos de encarregado e de operador de pá carregadeira foram determinados, de acordo com o piso salarial determinado pelo Sindicato da Indústria da Construção (Sinduscon) de Goiás. O salário para o cargo de engenheiro civil foi estabelecido com base em informações do Conselho Federal de Engenharia e Agronomia (CONFEA). Já para os cargos de operador de equipamentos, auxiliar de triagem e operador de balança foi considerado um salário médio praticado no Brasil (CATHO, 2017). Também foi considerado uma vigilância vinte e quatro (24) horas da usina, cujo custo foi determinado a partir do salário de dois (2) vigilantes por turno, sendo um turno diurno e o outro noturno. 0 salário de vigilante também foi baseado no piso salarial fornecido pelo Sinduscon de Goiás.

Foi considerado que todo o RCC gerado pelo município será recebido pela usina. A quantidade de RCC classe A (material que será transformado em agregado reciclado) que a usina irá receber foi estimada em 85\% do RCC total, conforme Stolz (2008). O preço cobrado para receber o RCC e o preço de venda do agregado reciclado foram estabelecidos com base em uma consulta na usina de RCC de Aparecida de 
Goiânia - GO, usina mais próxima de Itumbiara - GO. O preço do agregado reciclado foi comparado com o natural por meio de uma consulta a várias empresas de Itumbiara - GO que vendem agregado natural, com o fim de justificar o uso de um material reciclado pela população.

A receita da usina com a venda de agregados foi estimada em 85\%, 88\%, 90\%, 93\% e 95\% da sua capacidade de produção para os primeiros cinco anos (Stolz, 2008), devido à conquista de mercado que ocorrerá ano a ano na cidade. Para o investimento na usina, foi considerada uma Taxa Mínima de Atratividade (TMA) de 9,15\% a.a (ao ano), mesmo valor da taxa do Sistema Especial de Liquidação e de Custódia (SELIC), no período entre 27 de julho e 06 de setembro de 2017.

A fim de se obter o resultado da viabilidade econômica da usina, foram utilizados indicadores de viabilidade financeira como o Valor Presente Líquido (VPL), a Taxa Interna de Retorno (TIR) e o Payback descontado. 0 cálculo do VPL foi realizado por meio da Equação 2.

$$
\boldsymbol{V P} \boldsymbol{L}=\left[-P+\frac{N}{(1+i)}+\frac{N}{(1+i)^{2}}+\frac{N}{(1+i)^{3}}+\cdots+\frac{N}{(1+i)^{x}}\right] \quad \text { (Equação 2) }
$$

Onde: $\mathrm{VPL}=$ Valor Presente Líquido, $\mathrm{N}=$ Valor nominal, $\mathrm{P}=$ Capital inicial, $\mathrm{i}=$ Taxa de juros $=$ TMA.

O cálculo da TIR foi feito utilizando a calculadora financeira HP 12C, por meio da qual foram inseridos os dados do fluxo de caixa e a TMA. E quanto ao Payback descontado, foi determinado para este investimento um Payback descontado máximo de 7 (sete) anos para que o capital investido retorne para o investidor.

\section{RESULTADOS}

\subsection{CONSULTA NA PREFEITURA DE ITUMBIARA - GO}

Em consulta à Prefeitura de Itumbiara - GO foram obtidas informações sobre o RCC gerado pelo município junto à Secretaria de Ação Urbana. Segundo o secretário de ação urbana, Agnaldo Ferreira Cota, a grande maioria do RCC gerado, recolhido tanto pela prefeitura como por empresas de caçambas, é destinado a uma área de disposição final de resíduos sólidos, sendo que a parte descartada de forma irregular, assim que identificada pela prefeitura, também é destinada para essa área. A maior parte do entulho é do tipo cinza (concreto, argamassas) e a Prefeitura de Itumbiara tem controle somente do que chega na área de disposição final, com base no número de caminhões e na capacidade de carga deles, podendo os dados variarem para mais ou para menos. Os dados informados foram os seguintes:

- $\quad$ Turno Diurno: 4 caminhões (basculante), faz aproximadamente 20 viagens/dia $\times 5 \mathrm{t}=$ 100 toneladas/dia;

- $\quad$ Turno Noturno: 4 caminhões (basculante), faz aproximadamente 20 viagens/dia $\times 5 \mathrm{t}=$ 100 toneladas/dia;

- $\quad$ Caminhão Poli Guincho: 6 caminhões poli guincho, faz aproximadamente 30 viagens/dia $\mathrm{x} 4 \mathrm{t}=120$ toneladas/dia.

Com base nos dados fornecidos, obteve-se um total estimado de 320 toneladas de RCC/dia.

\subsection{VISITA TÉCNICA}

No dia 20 de agosto de 2017 foi realizada visita técnica ao local de disposição final dos resíduos sólidos do município de Itumbiara - GO. 0 local se localiza às margens da BR-452, entre os km 190 e 191, dentro do município de Itumbiara - GO (Figura 1). 
Figura 1: Local de disposição final dos resíduos sólidos do município de Itumbiara

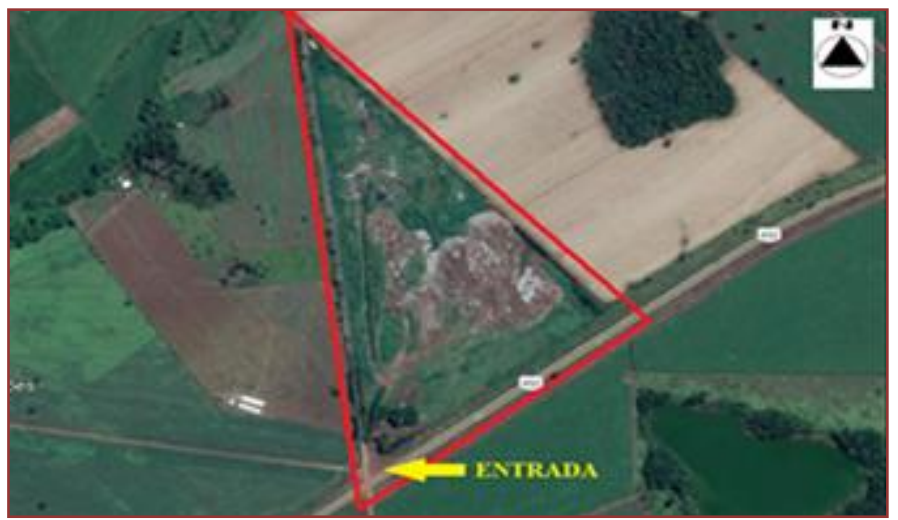

Foi realizada entrevista, por meio de questionário com a funcionária da prefeitura que trabalha na portaria, a fim de obter informações a respeito do RCC que é disposto no local. Segundo a funcionária da prefeitura, não se sabe a quantidade exata de entulho, pois o controle é baseado na quantidade de caçambas que chega. São dispostas no local uma média de 44 caçambas de entulho por dia, sendo 3 caçambas por viagem e 5 viagens da Disk Entulho, 1 caçamba e 7 viagens da Jacinto Engenharia, 2 caçambas e 5 ou 6 viagens da Prefeitura e 2 caçambas e 5 viagens da Bérgamo. A maioria das caçambas são de $5 \mathrm{~m}^{3}$ e a maior parte do entulho que chega é do tipo cinza (concreto), podendo vir misturado com um pouco de outros resíduos como lixo domiciliar.

Considerando o volume médio das caçambas de $5 \mathrm{~m}^{3}$, um total de 44 caçambas/dia e o peso específico médio do entulho, utilizado por Stolz (2008), de $1,6 \mathrm{t} / \mathrm{m}^{3}$, constata-se que o local recebe um total estimado de 352 toneladas de RCC/dia.

Durante a visita algumas constatações foram registradas por meio de fotos:

Em uma parte, havia uma grande quantidade de resíduos domésticos a céu aberto e em meio a eles, havia pessoas (catadores) e animais como urubus (Figura 2).

Figura 2: Urubus e catador em meio aos resíduos domésticos..

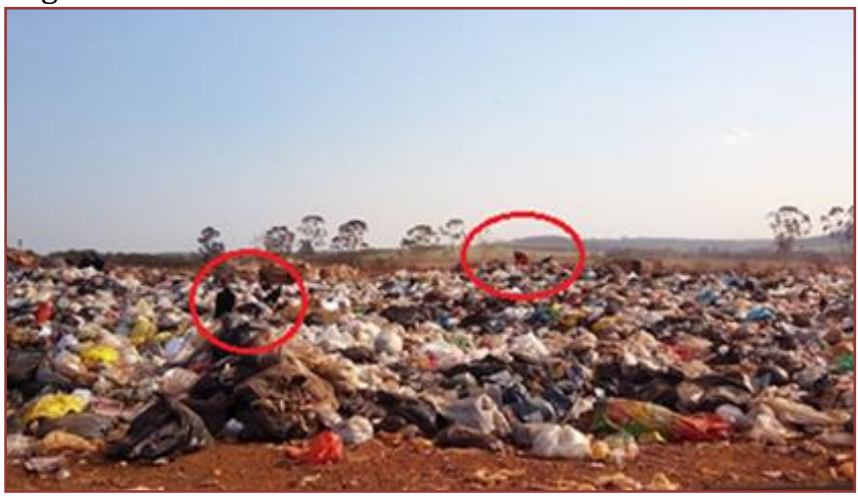

Fonte: Autor do trabalho 
Em outra parte era realizada a disposição do RCC, que mais tarde serviria para cobrir o resíduo doméstico. A maior parte dos montes eram compostos, predominantemente, de RCC classe A, principalmente de concreto e de material cerâmico (Figuras 3 a 6).

Figura 3: RCC com predominância classe A

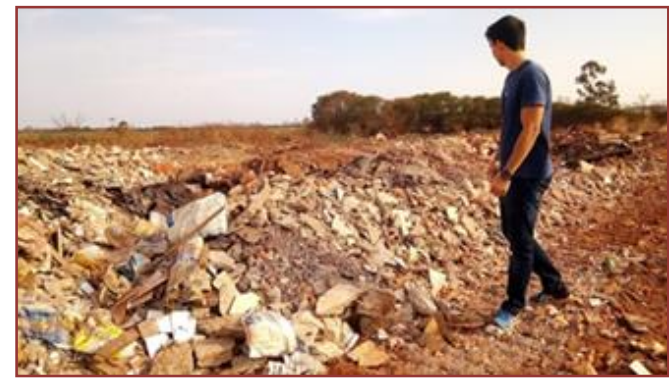

Fonte: Autor do trabalho.

Figura 5: Concreto em maior quantidade.

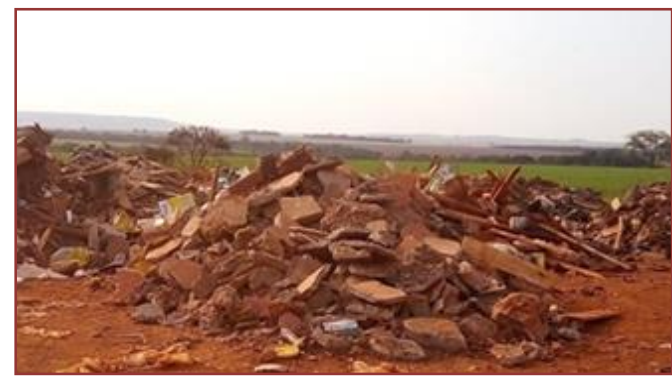

Fonte: Autor do trabalho
Figura 4: Blocos de concreto

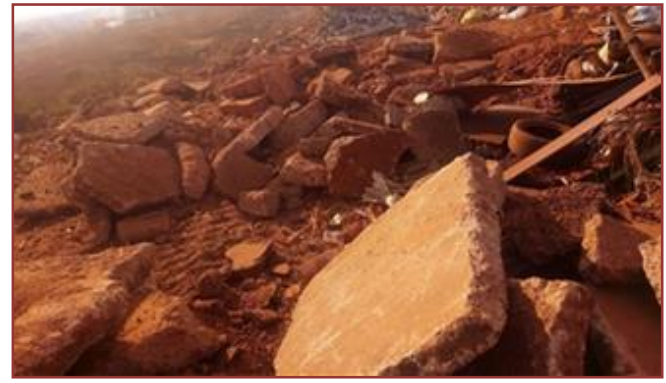

Fonte: Autor do trabalho.

Figura 6: Material cerâmico.

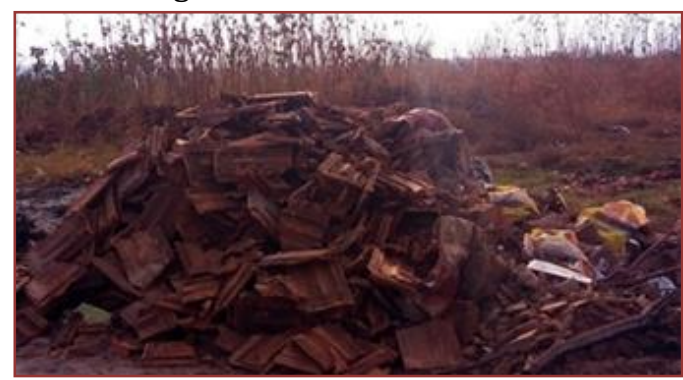

Fonte: Autor do trabalho.

Alguns montes apresentavam predominância de outros tipos de resíduos como madeira (RCC classe B) e em alguns havia a presença de resíduos domésticos (Figuras 7 e 8).

Figura 7: Madeira em maior quantidade

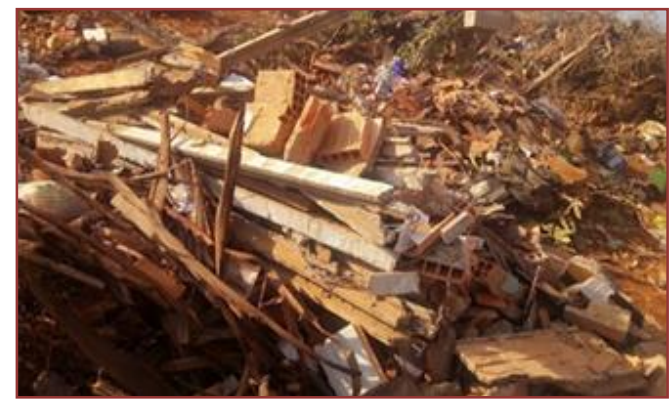

Fonte: Autor do trabalho.
Figura 8: Presença de resíduo doméstico

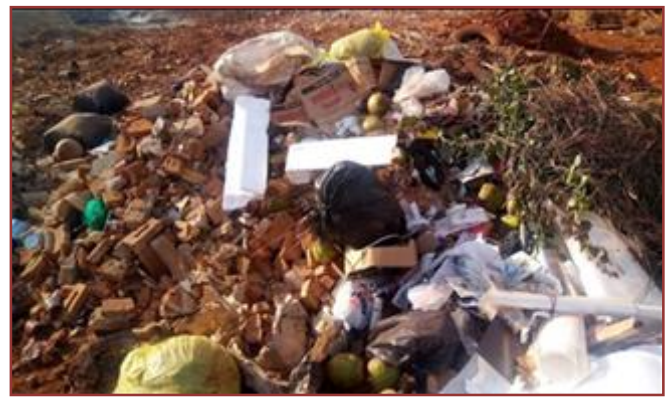

Fonte: Autor do trabalho.

Após a visita, pôde-se afirmar que o local de disposição dos resíduos não atende a legislação ambiental como, por exemplo, a Lei n. ${ }^{\circ}$ 12.305/2010 (PNRS), que dentre as suas disposições, proíbe a atividade de catação em áreas de disposição final de resíduos e rejeitos. Além disso, o local não atende as diretrizes correspondentes a uma área de aterro de inertes, conforme as diretrizes da NBR 15113/2004 (ABNT, 2004c) e nem mesmo a de uma área de aterro sanitário (ABNT, 1992), podendo ser enquadrado como um lixão. Isso também se confirma pelo fato do local não possuir licença ambiental, conforme informações da Agência Municipal de Meio Ambiente de Itumbiara (AMMAI). 


\subsection{VIABILIDADE ECONÔMICA}

\section{Investimento inicial (Custos de implantação)}

\section{Custos com a compra e instalação de equipamentos de britagem}

Diante do orçamento de três empresas, denominadas Empresa A, Empresa B e Empresa C, obteve-se os valores dos equipamentos de britagem (Tabela 3 ).

Tabela 3. Orçamentos de equipamentos de britagem. Fonte: Autor do trabalho.

\begin{tabular}{|c|c|}
\multicolumn{1}{|c}{ Empresa } & $\begin{array}{c}\text { Valor Total } \\
(\mathrm{R} \$)\end{array}$ \\
\hline Empresa A & $778.450,00$ \\
\hline Empresa B & $599.000,00$ \\
\hline Empresa C & $1.055 .000,00$ \\
\hline
\end{tabular}

Foi escolhido para o custo dos equipamentos o orçamento da Empresa B, pois apresentou o menor valor. Os equipamentos do orçamento fornecido por essa empresa estão apresentados na Tabela 4.

Tabela 4. Equipamentos - Empresa B. Fonte: Autor do trabalho.

\begin{tabular}{|l|c|}
\hline \multicolumn{1}{|c|}{ Equipamentos - Empresa B } & Quantidade \\
\hline Alimentador Vibratório - 20 a 40 T/h & 1 \\
\hline Britador Primário 20 a 40 T/h & 1 \\
\hline Peneira Vibratória 20 a 40 T/h & 1 \\
\hline Correia Transportadora Radial com Carrinho até 45 o & 1 \\
\hline Transportador de Correias Direcional a Radial & 4 \\
\hline Transportadores de Correias Finais & 1 \\
\hline Quadro Comando Elétrico & 1 \\
\hline Íman Magnético Fixo & - \\
\hline $\begin{array}{l}\text { Plataformas Metálicas de Fixação do Conjunto } \\
\text { Alimentador + Britador + Peneira Vibratória }\end{array}$ & - \\
\hline
\end{tabular}

O valor cobrado para a instalação mecânica dos equipamentos, pela mesma empresa, é de $\mathrm{R} \$ 59.000,00$. Com isso, o custo total referente à compra e instalação dos equipamentos é de $R \$ 658.000,00$.

\section{Custo com a aquisição de terreno}

Dentre os custos iniciais, foi desconsiderado o custo com a compra de um terreno que, devido a capacidade de produção do britador da empresa escolhida de 40 toneladas/hora, deve possuir uma área de $10.000 \mathrm{~m}^{2}$, conforme sugerido por Jadovski (2005). Foram definidas as dimensões, propondo uma área quadrada de $100 \mathrm{~m}$ x $100 \mathrm{~m}$.

\section{Custos com a compra de balanças e máquinas}

Foi orçado o preço de uma balança com montagem inclusa, de cerca de 10 a 12 metros de comprimento e capacidade de carga de 30 a 40 toneladas, em três empresas (Tabela 5). Essas empresas foram chamadas de Empresa X, Empresa Y e Empresa Z.

Tabela 5. Orçamentos - Balança. Fonte: Autor do trabalho.

\begin{tabular}{|c|c|}
\hline Empresa & Valor Total (R\$) \\
\hline Empresa X & $40.106,00$ \\
\hline Empresa Y & $38.768,00$ \\
\hline Empresa Z & $40.000,00$ \\
\hline
\end{tabular}

A empresa que apresentou o melhor custo para a balança foi a Empresa Y, com um custo total de $\mathrm{R} \$ 38.768,00$. Já o custo médio, para a pá carregadeira seminova, foi de $\mathrm{R} \$ 214.000,00$. Como serão duas (2) pás carregadeiras o custo total com elas é de $\mathrm{R} \$ 428.000,00$. 


\section{Custos com obras civis}

Foi designada a construção de uma guarita de $6 \mathrm{~m}^{2}$, de um escritório de $36 \mathrm{~m}^{2}$, de uma área de vivência de $30 \mathrm{~m}^{2}$, de um muro de $800 \mathrm{~m}^{2}$ (2 m x $400 \mathrm{~m}$ ) e a plantação de 400 mudas no entorno da área da usina (Tabela 6). As obras que utilizaram o valor de 70\% do CUB, tiveram um valor de $\mathrm{R} \$ 904,06 / \mathrm{m}^{2}$. Após a soma, obteve-se um custo total para as obras civis de $\mathrm{R} \$ 121.892,32$.

Tabela 6. Custo - Obra civis. Fonte: Autor do trabalho.

\begin{tabular}{|l|c|c|c|}
\multicolumn{1}{c}{ Obras civis } & $\begin{array}{c}\text { Valor unitário (R\$/Unid. } \\
\text { de medida) }\end{array}$ & Unidades & Valor Total (R\$) \\
\hline Guarita & $904,06 / \mathrm{m}^{2}$ & 6 & $5.424,36$ \\
\hline Escritório & $904,06 / \mathrm{m}^{2}$ & 36 & $32.546,16$ \\
\hline Área de vivência & $904,06 / \mathrm{m}^{2}$ & 30 & $27.121,80$ \\
\hline Muro & $71,00 / \mathrm{m}^{2}$ & 800 & $56.800,00$ \\
\hline Arborização & $0,00 / \mathrm{muda}$ & 400 & 0,00 \\
\hline \multicolumn{3}{|c|}{} & $121.892,32$ \\
\hline
\end{tabular}

\section{Fluxo anual de despesas (Custos anuais)}

\section{Custos com insumos de produção}

Através da Equação 3, foi obtido o seguinte custo mensal com consumo de água:

$$
\text { Custo mensal }=5.440 \times 0,08 \times 7,08=\mathrm{R} \$ 3.081,20 \quad \text { (Equação 3) }
$$

Assim, no decorrer de um ano, a usina apresentará um custo com água de $\mathrm{R} \$ 36.974,40$. 0 gasto com energia foi calculado por meio de informações da Tabela 1 e com base no tempo de funcionamento dos equipamentos escolhidos, que será em média de sete (7) horas/dia, chegando-se a um consumo diário de energia de 415,73 kW. Como foi adotado um período de funcionamento da usina de 20 dias/mês e o valor do $\mathrm{kW}$ /hora em Itumbiara - GO é de $\mathrm{R} \$ 0,67$, chegou-se a um custo anual com o consumo de energia de $\mathrm{R} \$ 66.849,40$. No caso do combustível, como foram adotadas duas (2) pás carregadeira com um consumo de 16 litros de diesel/hora cada, um período de operação de 7 horas/dia, 140 horas/mês e 1.680 horas/ano para cada uma das pás e o preço do diesel no valor de $\mathrm{R} \$ 3,19 /$ litro, foi calculado um custo anual no valor de $\mathrm{R} \$ 171.494,40$.

\section{Custos com mão de obra}

Foi considerado um total de dez (10) funcionários. Conforme sugerido por Jadovski (2005), oito (8) funcionários foram designados para o setor de produção da usina, considerandose: um (1) encarregado, um (1) operador para os equipamentos de britagem, dois (2) operadores de pá carregadeira e quatro (4) auxiliares para fazer a triagem do RCC. Os outros dois (2) funcionários serão: um (1) engenheiro civil e um (1) operador de balança. 0 custo mensal com os salários destes profissionais está apresentado na Tabela 7. Baseado nessa tabela, ao fim de um (1) ano, haverá um custo com mão de obra no valor de $\mathrm{R} \$ 228.204,60$.

Tabela 7. Custo mensal com mão de obra. Fonte: Autor do trabalho.

\begin{tabular}{|c|c|c|c|}
\hline Funcionários & Quantidade & $\begin{array}{l}\text { Salário Mensal } \\
\text { (R\$) }\end{array}$ & $\begin{array}{l}\text { Valor Total } \\
\text { (R\$) }\end{array}$ \\
\hline Encarregado & 1 & $2.079,00$ & $2.079,00$ \\
\hline $\begin{array}{l}\text { Operador - equipamentos de } \\
\text { britagem }\end{array}$ & 1 & $1.783,81$ & $1.783,81$ \\
\hline Operador - Pá carregadeira & 2 & $1.060,40$ & $2.120,80$ \\
\hline Auxiliar - Triagem & 4 & 995,20 & $3.980,80$ \\
\hline Engenheiro civil & 1 & $7.964,40$ & $7.964,40$ \\
\hline Operador de balança & 1 & $1.088,24$ & $1.088,24$ \\
\hline \multicolumn{3}{|c|}{ SOMA } & $19.017,05$ \\
\hline
\end{tabular}




\section{Custos com a compra de EPIs}

Com base no período de troca de EPIs sugerido por Jadovski (2005), considerando o número de funcionários da usina e os preços pesquisados, obteve-se o custo anual com a compra destes equipamentos, conforme Tabela 8.

Tabela 8. Custo anual com EPIs. Fonte: Autor do trabalho.

\begin{tabular}{|c|c|c|c|}
\hline \multicolumn{1}{|c|}{ EPIs } & Valor unitário (R\$) & $\begin{array}{c}\text { Quantidade } \\
\text { anual }\end{array}$ & $\begin{array}{c}\text { Valor Total Anual } \\
\text { (R\$) }\end{array}$ \\
\hline Calça & 13,00 & 20 & 260,00 \\
\hline Jaleco & 15,00 & 20 & 300,00 \\
\hline Camiseta & 11,00 & 40 & 440,00 \\
\hline Botina & 40,00 & 20 & 800,00 \\
\hline Luvas & 4,90 & 40 & 196,00 \\
\hline Capacete & 10,00 & 10 & 100,00 \\
\hline Óculos & 20,00 & 20 & 400,00 \\
\hline $\begin{array}{c}\text { Protetor } \\
\text { auricular }\end{array}$ & 2,00 & 120 & 240,00 \\
\hline \multicolumn{3}{|c}{} & $2.736,00$ \\
\hline
\end{tabular}

\section{Custos com manutenção dos equipamentos de britagem}

Como o valor do investimento inicial dos equipamentos de britagem é de $\mathrm{R} \$ 658.000,00$ e considerando uma taxa anual de manutenção de $3 \%$ deste valor, haverá um custo anual de manutenção no valor de $\mathrm{R} \$ 19.740,00$.

\section{Custos com vigilância}

O custo mensal com a vigilância da usina, considerando dois (2) turnos, dois (2) vigilantes por turno e um salário de $\mathrm{R} \$ 906,40$ por vigilante, será de $\mathrm{R} \$ 3.625,60$. Com isso, chega-se a custo total anual de $\mathrm{R} \$ 43.507,20$.

\section{Total de custos}

0 custo total com o investimento inicial, assim como o custo total de manutenção e operação anual da usina estão apresentados na Tabela 9.

Tabela 9. Total de custos. Fonte: Autor do trabalho.

\begin{tabular}{|c|c|c|}
\hline Custos & Descrição & Valor $(\mathrm{R} \$)$ \\
\hline \multirow{4}{*}{ Investimento inicial } & Equipamentos de britagem & $658.000,00$ \\
\hline & Balança & $38.768,00$ \\
\hline & Pás carregadeira & $428.000,00$ \\
\hline & Obras civis & $121.892,32$ \\
\hline \multicolumn{2}{|r|}{ SOMA } & $1.246 .660,32$ \\
\hline \multirow{7}{*}{ Fluxo anual de despesas } & Água & $36.974,40$ \\
\hline & Energia & $66.849,40$ \\
\hline & Combustível (Diesel) & $171.494,40$ \\
\hline & Mão de obra & $228.204,60$ \\
\hline & $\begin{array}{c}\text { EPIs } \\
\end{array}$ & $2.736,00$ \\
\hline & Manutenção dos equipamentos de britagem & $19.740,00$ \\
\hline & Vigilância & $43.507,20$ \\
\hline \multicolumn{2}{|r|}{ SOMA } & $569.506,00$ \\
\hline
\end{tabular}

\section{Fluxo anual de benefícios (Receitas)}

A usina de RCC obterá receita a partir da cobrança pelo recebimento de RCC e por meio da venda de agregados reciclados. 


\section{Receita com o recebimento do entulho}

Foi considerado o recebimento de todo o RCC gerado pelo município, ou seja, cerca de 320 toneladas de RCC/dia na usina, conforme dados oficiais da Prefeitura de Itumbiara - GO. Como foi adotado um peso específico médio do RCC de 1,6 tonelada/ $\mathrm{m}^{3}$ (STOLZ, 2008), estima-se que será recebido na usina um total de $200 \mathrm{~m}^{3}$ de RCC/dia, de $4.000 \mathrm{~m}^{3}$ de RCC/mês, considerado 20 dias/mês, e de $48.000 \mathrm{~m}^{3}$ de RCC/ano. Baseado na usina de Aparecida de Goiânia - G0, que cobra pelo recebimento do RCC valores entre R\$5,00 a $\mathrm{R} \$ 30,00 / \mathrm{m}^{3}$ de RCC, foi estabelecido um valor médio de cobrança pelo resíduo de $\mathrm{R} \$ 17,50 / \mathrm{m}^{3}$ resultando em uma receita de $\mathrm{R} \$ 840.000,00$ por ano.

\section{Receita com a venda de agregados reciclados}

Como a quantidade de RCC classe A que será britado foi estimada em 85\% do RCC recebido (STOLZ, 2008), chegou-se a uma quantidade de agregado reciclado no total de $170 \mathrm{~m}^{3} / \mathrm{dia}$, de $3.400 \mathrm{~m}^{3} / \mathrm{mês}$ e de 40.800 $\mathrm{m}^{3}$ /ano. Considerando que o agregado reciclado será vendido a um preço médio de $\mathrm{R} \$ 28,50 / \mathrm{m}^{3}$, já que o preço praticado pela usina de Aparecida de Goiânia - GO é de R\$25,00 a R\$32,00/ $\mathrm{m}^{3}$, resulta-se em uma receita anual no valor de $\mathrm{R} \$ 1.162 .800,00$. Foi considerado que haverá uma conquista de mercado nos cinco (5) primeiros anos. Conforme Stolz (2008), a quantidade de agregado vendido foi estimado, respectivamente, em 85\%, 88\%, 90\%, 93\% e 95\% do total produzido, resultando em receitas diferentes nos primeiros anos (Tabela 10). O preço médio do agregado natural praticado em Itumbiara -GO é de $\mathrm{R} \$ 88,75$. Dessa forma, o agregado reciclado irá apresentar um valor 67,9\% mais barato do que o agregado natural, sendo um fator que justifica a compra do material.

Tabela 10. Receita com venda de agregado reciclado. Fonte: Autor do trabalho.

\begin{tabular}{|c|c|c|}
\hline Ano & $\begin{array}{c}\text { Porcentagem de vendas de } \\
\text { agregado reciclado (\%) }\end{array}$ & Receita (R\$) \\
\hline $1^{\circ}$ ano & 85 & $988.380,00$ \\
\hline $2^{\circ}$ ano & 88 & $1.023 .264,00$ \\
\hline $3^{\circ}$ ano & 90 & $1.046 .520,00$ \\
\hline $4^{\circ}$ ano & 93 & $1.081 .404,00$ \\
\hline 5o ano & 95 & $1.104 .660,00$ \\
\hline A partir do $6^{\circ}$ ano & 100 & $1.162 .800,00$ \\
\hline
\end{tabular}

\section{Análise da viabilidade econômica}

A partir do cálculo do VPL, a TIR e o Payback descontado, chegou-se ao resultado da viabilidade da usina de reciclagem de RCC proposta. Usando como base os dados do fluxo de caixa (Tabela 11) e a Equação 2, obteve-se um valor do VPL de +5.478.822,08. Como o VPL > 0, o investimento é viável.

Tabela 11. Fluxo de caixa. Fonte: Autor do trabalho.

\begin{tabular}{|c|c|}
\multicolumn{1}{c}{$\begin{array}{c}\text { Período } \\
\text { Fluxo de Caixa } \\
\text { (R\$) }\end{array}$} \\
\hline 0 & $-1.246 .660,32$ \\
\hline 1 & $+1.268 .874,00$ \\
\hline 2 & $+1.293 .758,00$ \\
\hline 3 & $+1.317 .014,00$ \\
\hline 4 & $+1.351 .898,00$ \\
\hline 5 & $+1.375 .154,00$ \\
\hline 6 & $+1.433 .294,00$ \\
\hline 7 & $+1.433 .294,00$ \\
\hline
\end{tabular}


Taxa de juros $=$ TMA $=9,15$

$$
\begin{aligned}
\text { VPL }=-1.246 .660,32+\frac{1.268 .874,00}{(1+0,0915)^{1}}+\frac{1.293 .758,00}{(1+0,0915)^{2}}+\frac{1.317 .014,00}{(1+0,0915)^{3}} \\
+\frac{1.351 .898,00}{(1+0,0915)^{4}}+\frac{1.375 .154,00}{(1+0,0915)^{5}}+\frac{1.433 .294,00}{(1+0,0915)^{6}}+\frac{1.433 .294,00}{(1+0,0915)^{7}} \\
=+5.478 .822,08
\end{aligned}
$$

A partir da inserção dos dados do fluxo de caixa (Tabela 11) e da TMA na calculadora financeira HP 12C, foi encontrado uma TIR no valor de $103 \%$. Como a TIR > TMA, o investimento também é considerado viável por este indicador.

0 período de Payback descontado do investimento foi encontrado a partir dos dados da Tabela 12. A partir do $2^{\circ}$ ano o fluxo de caixa descontado acumulado é positivo, podendo afirmar que nesse período já se conseguiu o Payback descontado. Mais precisamente, o período necessário para que o investidor recupere seu investimento inicial de R\$1.246.660,32 é de 1 (um) ano e 28 (vinte e oito) dias. Como foi determinado um período máximo de Payback descontado de 7 (sete) anos e o mesmo é conseguido em um tempo menor, significa que o investimento é viável.

Tabela 12. Fluxo de caixa descontado. Fonte: Autor do trabalho.

\begin{tabular}{|c|c|c|} 
Período & \multicolumn{1}{c}{$\begin{array}{c}\text { Fluxo de Caixa } \\
\text { Descontado (R\$) }\end{array}$} & $\begin{array}{c}\text { Fluxo de Caixa } \\
\text { Descontado } \\
\text { Acumulado (R\$) }\end{array}$ \\
\hline 0 & $-1.246 .660,32$ & $-1.246 .660,32$ \\
\hline 1 & $+1.162 .505,00$ & $-84.155,32$ \\
\hline 2 & $+1.085 .939,00$ & $+1.001 .783,68$ \\
\hline 3 & $+1.012 .789,00$ & $+2.014 .572,68$ \\
\hline 4 & $+952.464,90$ & $+2.967 .037,58$ \\
\hline 5 & $+887.631,40$ & $+3.854 .668,98$ \\
\hline 6 & $+847.603,70$ & $+4.702 .272,68$ \\
\hline 7 & $+776.549,40$ & $+5.478 .822,08$ \\
\hline
\end{tabular}

\section{CONCLUSÕES}

0 presente estudo buscou verificar e analisar a viabilidade econômica para a instalação de uma usina de reciclagem de RCC no município de Itumbiara - GO, contribuindo para que o mesmo se adeque à legislação ambiental em vista da problemática com a disposição final inadequada destes resíduos, visto que atualmente deposita seus RCC em um lixão, área sem licença ambiental. Além disso, contribui para que mais estudos relativos a usinas de reciclagem de RCC sejam desenvolvidos, servindo como exemplo de comparação e consulta.

A usina proposta irá receber, conforme levantamento feito, cerca de $320 \mathrm{t}$ de RCC/dia, sendo adotados equipamentos com capacidade de processamento de 40 t/hora. Serão produzidos na usina agregados reciclados como areia, pedrisco, brita e rachão, possuindo um valor de mercado $67,9 \%$ mais barato que o agregado natural comercializado em Itumbiara - G0, o que justifica a compra do material.

Com base nos custos considerados, a implantação da usina necessitará de um investimento inicial de $\mathrm{R} \$ 1.246 .660,32$ e apresentará um fluxo de gastos por ano no valor de $\mathrm{R} \$ 569.506,00$. 0 faturamento da usina com o recebimento de RCC será de R $\$ 840.000,00$ por ano. Já com a venda de agregados reciclados a usina obterá um faturamento anual crescente, sendo estimada a venda de $85 \%, 88 \%, 90 \%, 93 \%$ e $95 \%$ dos agregados ao longo dos 5 (cinco) primeiros anos devido à conquista de mercado, e de $100 \%$ a partir do sexto ano.

A partir do cálculo dos indicadores de viabilidade financeira, foi obtido um VPL de + 5.478.822,08, uma TIR de $103 \%$ e um Payback descontado de 1(um) ano e 28 (vinte e oito) dias, mostrando que o investimento inicial deverá ser recuperado em um período de tempo relativamente rápido, sendo o investimento, portanto, bastante viável. 
[1] Associação Brasileira de Normas Técnicas (ABNT). NBR 8419: Apresentação de projetos de aterros sanitários de resíduos sólidos urbanos. Rio de Janeiro, 1992.

[2] Associação Brasileira de Normas Técnicas (ABNT). NBR 15113: Resíduos sólidos da construção civil e resíduos inertes - Aterros - Diretrizes para projeto, implantação e operação. Rio de Janeiro, 2004c.

[3] Associação Brasileira para Reciclagem de Resíduos da Construção e Demolição (ABRECON). Relatório Pesquisa Setorial 2014/2015: A reciclagem de resíduos de construção e demolição no Brasil. Paraná, 2015.

[4] Brasil. Conama no 307. Estabelece diretrizes, critérios e procedimentos para a gestão dos resíduos da construção civil. Conselho Nacional do Meio Ambiente, 2002.

[5] Brasil. Lei n.o 12.305, de 02 de agosto de 2010. Institui a Política Nacional de Resíduos Sólidos. Brasília, 2010.

[6] Casa Dicas. Quanto custa a construção de um muro por m2?. 2014. Disponível em: <http://www.casadicas.com.br/construcao/quanto-custa-a-construcao-de-um-muro-por-m2/>. Acesso em: 09 de outubro de 2017.

[7] Catho. Guia de profissões e salários. 2017. Disponível em: <https://www.catho.com.br/profissoes/>. Acesso em: 12 de outubro de 2017.

[8] Conselho Federal de Engenharia e Agronomia (CONFEA). Salário Mínimo Profissional. Disponível em: <http://www.confea.org.br/cgi/cgilua.exe/sys/start.htm?sid=1009>. Acesso em: 12 de outubro de 2017.

[9] GOOGLE MAPS. Itumbiara - G0. 2017. Disponível em:

<https://www.google.com.br/maps/place/Itumbiara+-+GO/@-

18.3718476,50.0402042,9z/data=!3m1!4b1!4m5!3m4!1s0x94a10d6489383995:0xa0d3f8f904066d35!8m2 !3d-

18.4097245!4d-49.2162908>. Acesso em: 26 de setembro de 2017.

[10] Helou, C. Pró Industrial. Goiânia: ed. Adial, edição 80, ano VIII, 02 de dezembro de 2016. 20p.

[11] Jadovski, I. Diretrizes técnicas e econômicas para usinas de reciclagem de resíduos de construção e demolição. 2005. 167 f. Dissertação (Mestrado Profissionalizante em Engenharia) - Universidade Federal do Rio Grande do Sul, Porto Alegre, 2005.

[12] Manfrinato, J. W. S.; Esguícero, F. J.; Martins, B. L. Implementação de usina para reciclagem de resíduos da construção civil (RCC) como ação para o desenvolvimento sustentável - estudo de caso. In: Encontro Nacional de Engenharia de Produção, 28, 2008, Rio de Janeiro. Anais... Rio de Janeiro: Abepro, 2008. p.1 - 12.

[13] Pinto, T. P. Metodologia para a gestão diferenciada de resíduos sólidos da construção urbana. 1999.189 f. Tese (Doutorado em Engenharia) - Escola Politécnica da Universidade de São Paulo, São Paulo, 1999.

[14] Sinduscon - GO. CUB - Custo Unitário Básico de Construção. 2017. Disponível em: <http://www.sinduscongoias.com.br/index.php/en/cub.html>. Acesso em: 09 de outubro de 2017.

[15] Stolz, C. M. Viabilidade econômica de usinas de reciclagem de RCC: Um estudo de caso para Ijuí/RS. 2008.93 f. Trabalho de conclusão de curso (Graduação em Engenharia Civil) - Universidade Regional do Noroeste do Estado do Rio Grande do Sul, Ijuí, 2008. 


\section{Capítulo 12}

\section{Análise da adição do resíduo Cal de Carbureto no}

concreto

\section{Julianna Muller da Silva \\ Fernando de Farias Fernandes}

Resumo: Esta pesquisa tem como objetivo principal analisar a possibilidade de adição do resíduo Cal de Carbureto no concreto, mantendo a qualidade original do produto, ou ainda até melhorando-o. A proposta de utilizar esse aditivo surgiu devido a necessidade do reaproveitamento de resíduos, pois as indústrias em geral, como por exemplo a geradora de acetileno tem produzido uma quantidade excessiva de rejeito, a qual é destinado para o aterro industrial, não sendo a solução mais adequada para o Meio Ambiente. Na finalidade de reduzir esse impacto negativo, utilizou-se o uso dessa Cal de Carbureto como aditivo no concreto nas porcentagens de 5, 10 e 15\% deste resíduo, com a resistência de 30 MPa na finalidade de estudar os seus efeitos em relação à resistência axial, absorção de água, e abatimento, comparando os resultados em relação ao concreto convencional. A melhor resistência obtida foi encontrada no corpo-de-prova com 10\% de Cal de Carbureto.

Palavras Chave: Cal de Carbureto. Aditivo. Resíduo. 


\section{INTRODUÇÃO}

Em virtude da preocupação mundial com o Meio Ambiente, um importante questionamento foi instaurado a respeito do estilo de vida das pessoas, o que se repercutiu em grande escala, na busca de novos materiais para desenvolvimento de produtos.

Dessa forma, as grandes empresas, entre elas, o ramo da Construção Civil, passaram a buscar maneiras de reutilizar os resíduos sólidos, seja na forma de matéria-prima ou insumo, pois notou-se que a utilização desses rejeitos, além de ser benéfico para a Natureza, também levaria a uma redução de despesas, devido a economia com o material (Santos,2009).

A cal de carbureto, resíduo analisado no presente trabalho, é formado durante a produção do gás acetileno, e após seu processo de formação, é destinado à aterros industriais, existindo maneiras mais adequada para tal descarte, como por exemplo, seu reaproveitamento como matéria prima ou insumo. (Fernandes, 2002).

No intento de gerenciar esse resíduo sólido, o objetivo geral do trabalho vigente consiste em averiguar a possibilidade de adição da Cal de Carbureto no Concreto, levando em consideração os resultados obtidos no ensaios de resistência axial, abatimento do concreto, e absorção de água, comparando corpos de provas com 5,10 e 15 \% de adição da cal, com o concreto de referência.

\section{METODOLOGIA}

O procedimento utilizado consistiu em dosar corpos de provas com adição de 5, 10 e 15\% do resíduo cal de carbureto e um corpo de prova sem esse aditivo, o qual é chamado de concreto referencial, e todos foram desenvolvidos numa consistência plástica, com traço calculado pelo método ABCP, na proporção de 1:1,5:2,5:0,48 (cimento, areia, seixo e água) por meio do Programa Microsoft Excel para serem realizados os ensaios de resistência à compressão, absorção de água e abatimento do concreto.

Em relação à quantidade de corpos de prova por traço, foi escolhido o número de três exemplares por traço e por idade para uma precisão maior do resultado, e quanto à idade dos corpos de provas, foram selecionadas as de 7,28 e 44 dias para o ensaio de resistência axial e a idade de 28 dias para o ensaio de absorção, segundo, respectivamente, a NBR 5738:2015 e a NBR 9778:1987, como mostrado através da tabela 1.

Tabela 1 - Amostra dos Corpos de Prova por Ensaio

\begin{tabular}{|c|c|c|}
\multicolumn{1}{c}{$\begin{array}{c}\text { Corpos de Provas por } \\
\text { Ensaio }\end{array}$} & \multicolumn{2}{c|}{$\begin{array}{c}\text { Resistência Axial } \\
\text { Absorção de } \\
\text { Água }\end{array}$} \\
\hline Idades a serem estudadas & 7,28 e 44 dias & 28 dias \\
\hline Corpos de Prova por idade & 3 & 3 \\
\hline Corpos de Prova por traço & 9 & 3 \\
\hline Total de Corpos de Prova & 36 & 12 \\
\hline
\end{tabular}

Fonte: Própria (2019).

Quanto ao ensaio de abatimento do concreto, também conhecido como "slump test", é realizado durante a moldagem dos corpos de prova para analisar a trabalhabilidade do concreto, seguindo as orientações da NBR NM 67:1996. 0 traço moldado foi calculado para um abatimento de $6 \pm 1$.

Após a realização dos três ensaios propostos no trabalho em pauta, os resultados obtidos serão comparados entre si, em busca de resultados positivos para os corpos de prova com adição de cal de carbureto em sua composição, a fim de adquirir uma destinação correta para estes resíduos.

\section{RESULTADOS E DISCUSSÃO}

Em relação aos ensaios de resistência axial, absorção de água e abatimento, foram obtidos os seguintes resultados: 


\subsection{RESISTÊNCIA AXIAL}

O concreto confeccionado possuía resistência estimada de 30 Mpa para 28 dias de idade, e como o aditivo utilizado é um material pozolânico, o desempenho mecânico tende a ser mais elevado em idades mais avançadas (Leite,2001).

Para os ensaios realizados, os corpos de prova tanto os referenciais como os que possuíam cal de carbureto foram capeados de acordo com a NBR 5738:2015, conforme a imagem da figura 1.

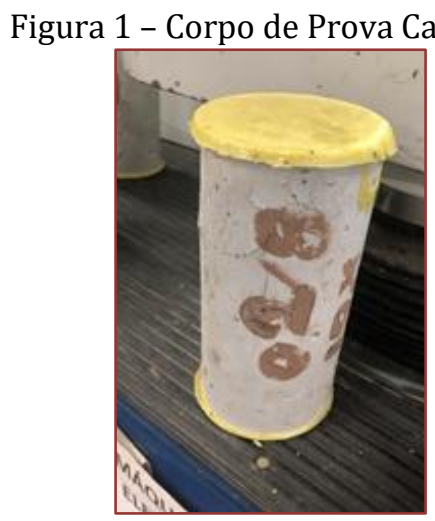

Fonte: Própria (2019).

Ao serem rompidos os três corpos de prova para cada idade e para traço, observou-se que as resistências obtidas foram semelhantes entre si, e estão serão apresentadas na tabela 2.

Tabela 2 - Comparativo de Resistência Axial

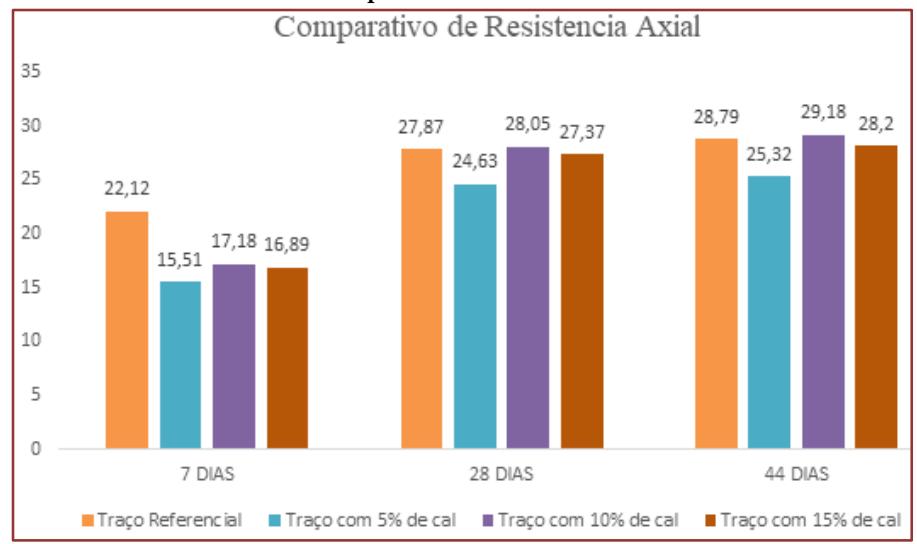

Fonte: Própria (2019).

Como demonstrado na tabela 2, na idade de 28 e 44 dias, a maior resistência encontrada entre os corpos de prova foi no traço com adição de $10 \%$ de cal de carbureto, mais elevado que o próprio concreto referencial, trazendo um resultado bastante positivo para a esta pesquisa.

\subsection{ABATIMENTO DO CONCRETO}

Segundo da Silva et al. (2018), a cal de carbureto por ser uma derivação da cal, aumenta o consumo de água, por seguinte, formando uma junção maior das partículas. Dessa forma, o concreto com adição de cal de carbureto tenderá a melhorar a plasticidade do artefato de concreto e diminuir o abatimento do concreto. 
Ao ser realizado o ensaio de abatimento, comprovou-se esse padrão em relação a cal de carbureto. No concreto padrão, o slump test encontrado foi de $10 \mathrm{~cm}$. Já no corpos de prova com aditivo, o slump foi obtendo valores menores, com 8,7 e $5 \mathrm{~cm}$ para os valores de 5, 10 e 15\% do aditivo, melhorando seu abatimento.

\subsection{ABSORÇÃO DE ÁGUA}

Ainda segundo da Silva et al. (2018), a proporção entre o coeficiente de capilaridade é inversa ao tamanho dos raios capilares, significando a preferência pela obtenção de raios maiores.

Com a adição de Cal de Carbureto, a área superficial das partículas é aumentada, elevando o consumo de água. Os vazios presentes no concreto são preenchidos por partículas finas, conduzindo a água, que atua como facilitadora do deslizamento das partículas, permitindo um melhor encaixe e mobilidade das mesmas.

Ao realizar esse ensaio, foi comprovado tal fato entre todos os corpos de prova, apresentando maior absorção de água os corpos de prova com 15\% de aditivo inserido.

\section{CONCLUSÕES}

Ao analisar a influência da cal de carbureto sobre os ensaios de resistência axial, abatimento do concreto, e absorção de água, observou-se resultados positivos, principalmente, nos corpos de prova de 10 e $15 \%$. Porém, como a resistência encontrada no corpo de prova com $10 \%$ de aditivo foi maior do que o valor obtido no concreto referencial, considera-se este o melhor resultado da pesquisa. Dessa forma, verifica-se que é possível utilizar esse resíduo como aditivo no concreto, evitando uma destinação final inadequada e consequentes impactos negativos no Meio Ambiente.

\section{AGRADECIMENTOS}

Gostaria de agradecer primeiramente a Deus, pelo sopro de vida e por ter me concedido capacidade de concluir esse trabalho; à minha família, pelo apoio incondicional; ao meu orientador, que nunca faltou com instruções válidas nem paciência, aos colegas que ajudaram na elaboração do trabalho, aos laboratoristas e a todos que serviram para realizar esse sonho. Obrigada.

\section{REFERÊNCIAS}

[1] Associação Brasileira de Normas técnicas. ABNT NM 67:1998, de fevereiro de 1998. Concreto - Determinação da consistência pelo abatimento do tronco de cone. Disponível em: < http://professor.pucgoias.edu.br/SiteDocente/admin/arquivosUpload/15030/material/NBR\%20NM\%2067\%20\%2098_aula.pdf>. Acesso: 20.mai.2019

[2] Associação Brasileira de Normas Técnicas. NBR 9778:2005, de agosto de 2005. Argamassa e concreto endurecidos - Determinação da absorção de água, índice de vazios e massa específica. Disponível em: < https://www.abntcatalogo.com.br/norma.aspx?ID=52163>. Acesso: 10.mai.2019

[3] Associação Brasileira de Normas Técnicas. ABNT NBR 5738:2015, de janeiro de 2015. Concreto Procedimento para moldagem e cura de corpos de prova. Disponível em:

<http://professor.pucgoias.edu.br/SiteDocente/admin/arquivosUpload/15030/material/NBR\%205738\%20\%2015_aula.pdf>. Acesso em: 04. Mai.2019

[4] Da Silva, Ff; Fiuza, Gfs; Neves, Lhsb; Gomes, GJC. Estudo da influência de cal hidratada na permeabilidade do concreto. Revista Teccen. 2018 Jan/Jun.; 11 (1): 02-09.

[5] Fernandes, F.F. 0 uso de Cal de Carbureto na estabilização do solo. Manaus, 2002.

[6] Leite, M.B. Avaliação de propriedades mecânicas de concretos produzidos com agregados reciclados de construção e demolição. 270 f. Tese (Doutorado). Porto Alegre, 2001.

[7] Santos, M. P. D. Fabricação de solo-cimento com adição de resíduos de madeira provenientes da construção civil. Belo Horizonte, 2009. 


\section{Capítulo 13}

Estudo da utilização do resíduo de Caulim como substituto parcial do agregado miúdo na produção de concreto para intertravados

Thyago Lima Souza

Maria Isabel de Araújo Nóbrega

Fellipe Dalyson Gadelha Silva

Thiago da Nóbrega Sousa

Larissa Santana Batista

Resumo: A geração de resíduos proveniente das atividades de mineração ocasiona graves impactos na natureza, desde a extração até a sua transformação em produto final. O caulim é um exemplo de mineral que gera uma grande quantidade de resíduos, proveniente do seu processo de beneficiamento. 0 estudo da utilização deste residuo como agregado é um meio viável de reduzir as consequências causadas pela sua disposição na natureza. Além disso, reduz a necessidade de extração do agregado natural, a areia, utilizado em enorme quantidade pelo setor da construção civil, diminuindo assim os diversos problemas socioambientais causados por essa atividade. Desse modo, o presente trabalho objetiva avaliar a substituição do agregado miúdo por resíduo de caulim nas proporções de $10 \%, 20 \%$ e 30\%, buscando analisar a viabilidade de sua utilização em concretos para peças de pavimento intertravado. Foram realizados os ensaios de caracterização fisica dos materiais empregados para a determinação do traço de referência e em seguida a caracterização do concreto por meio dos ensaios de resistência à compressão, absorção de água e resistência à abrasão, conforme prescreve a ABNT NBR 9781/13. Os resultados indicaram uma redução na resistência à compressão aos sete dias, quanto maior o teor de utilização do resíduo de caulim, em comparação ao traço de referência. Com relação à resistência à compressão aos 28 dias, o traço com substituição de $10 \%$ do agregado natural pelo rejeito atingiu resistência superior à mínima estabelecida pela norma de $35 \mathrm{MPa}$. 0 mesmo traço atendeu também aos valores máximos de absorção de água e abrasão, tornando viável tecnicamente a sua utilização na produção de peças para pavimento intertravado.

Palavras-chave: Paver, Pavimento Intertravado, Resíduo de Caulim, Concreto. 


\section{INTRODUÇÃO}

Com a revolução industrial surgiu uma crescente demanda no setor da mineração acarretando graves consequências ambientais com a elevada geração de resíduos. Muitas vezes realizadas de modo rudimentar, o processo de beneficiamento dos minerais promove perdas significativas, sendo descartados em locais a céu aberto, afetando as pessoas que moram próximos a esses depósitos indevidos de destinação.

Atrelado a isso se tem a extração exarcebada da areia para utilização como agregado para concreto, que geralmente ocorre em locais próximos a fundo de vales e rios, afetando o escossistema em que está inserido.

Conforme o relatório da ANEPAC (2015), o consumo de agregados no Brasil alcançou 741 milhões de toneladas em 2014. Nesse mesmo ano, os agregados corresponderam a $2 / 3$ do total da produção mineral no mundo, com 45 bilhões de toneladas, enquanto todos os demais minerais representaram somente 20 bilhões.

A corrida pelo desenvolvimento econômico tem causado preocupação com o futuro dos recursos ambientais devido a sua exploração de forma exacerbada e predatória. A falta de fiscalização nas áreas de extração contribui para o agravamento dos efeitos negativos tanto ambientais como sociais, pois afeta também as localidades próximas (SANTOS, 2015).

Diante desse cenário, vários resíduos oriundos de atividades mineradoras têm sido utilizados como agregados alternativos para a produção de concreto, destacando-se o resíduo de caulim. Barbosa et al. (2016) utilizaram o resíduo de caulim como substituto da areia nas proporções de $75 \%$ e $100 \%$ na produção de concreto com traço usualmente empregado na construção civil de 1:3:3. Apesar do agregado reciclado proporcionar baixa resistência ao concreto, o mesmo conferiu uma ótima trabalhabilidade a mistura e um excelente acabamento a peça.

O pavimento intertravado é composto por várias camadas que recebem e distribuem as cargas solicitadas por pessoas e/ou veículos. A camada de revestimento é composta por peças de concreto intertravadas umas com as outras, onde além de impedir o deslocamento, transmitem os esforços para as demais peças vizinhas (KNAPTON, 1976).

A ABNT NBR 9781/2013 define pavimento intertravado como um pavimento flexível com uma estrutura composta por base, sub-base (esta podendo ou não existir), camada de assentamento e a camada de revestimento, constituída por peças de concreto com suas juntas preenchidas por material de rejuntamento e o intertravamento de todo o sistema proporcionado pela contenção.

O caulim, por sua vez, bastante utlizado na indústria de papel, apresenta um grande potencial mineral, pois possui em sua constituição caulim, mica moscovita e quartzo, motivando, assim, estudos para o desenvolvimento de tecnologias visando o aproveitamento desse material em diversas áreas (MENDONÇA et al., 2017).

De acordo com Resende et al. (2008), cerca de 80 a 90\% do caulim extraído vira rejeito. Esse resíduo gerado é depositado na natureza, implicando em vários problemas para o meio ambiente, além de severas fiscalizações e eventuais multas que essas empresas recebem de órgãos ambientalistas. A Figura 1 mostra os depósitos desse resíduo localizados na cidade de Junco do seridó, na Paraíba.

Desse modo, esse trabalho visa à utilização de resíduo de caulim como substituto parcial do agregado miúdo no concreto para fabricação os blocos que compõem o pavimento intertravado, verificando as resistências à compressão, à abrasão e a absorção de água das peças, contribuindo como material alternativo para a redução da extração de matérias-primas e da geração de resíduos. 
Figura 1 - Depósitos de resíduo de caulim na cidade de Junco do Seridó - PB.

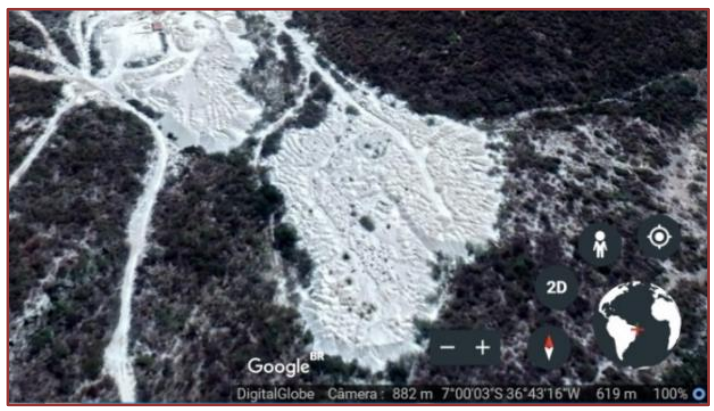

Fonte: Autor, 2019.

\section{METODOLOGIA}

Para o desenvolvimento das análises do desempenho das peças frente à substituição parcial do agregado miúdo pelo resíduo do caulim foi realizada a caracterização dos materiais constituintes do concreto, em seguida a moldagem das peças e a avaliação física e mecânica das mesmas, por meio dos ensaios de resistência a compressão, resistência à abrasão e absorção de água.

Os materiais empregados nestes trabalhos estão elencados a seguir:

- $\quad$ Agregado miúdo composto de areia e pó de pedra;

- $\quad$ Agregado graúdo composto de brita 0;

- $\quad$ Resíduo de caulim, obtido na cidade de Junco do Seridó - PB;

- $\quad$ Cimento CP V - ARI.

A escolha do cimento do tipo CP V se deu porque a maioria das empresas que produzem pré-moldados utilizam este tipo de cimento pelo fato do mesmo atingir altos valores de resistência nas primeiras idades de cura, facilitando assim um rápido escoamento das peças no mercado.

Para caracterização física dos materiais usados na confecção do concreto foram executados os ensaios de acordo com as normas da ABNT, dispostos a seguir:

- Composição granulométrica - NBR NM 248/2003;

- $\quad$ Massa unitária dos agregados - NBR NM 45/2006;

- $\quad$ Massa específica dos agregados miúdos - NBR NM 52/2009;

- $\quad$ Massa específica do agregado graúdo - NBR NM 53/2009.

Após a caracterização dos materiais utilizados, realizou-se a definição do traço de referência e os traços de substituições do agregado miúdo natural pelo resíduo do caulim com as porcentagens de $10 \%, 20 \%$ e $30 \%$. Foram adotados baixos valores de substituição com base em estudos realizados por Barbosa et al. (2016), onde foi possível verificar que a utilização de altos valores de substituição ocasionaram em reduções consideráveis da resistência à compressão.

Definidos os traços, foram realizadas a moldagem das peças, cujos moldes possuem formato prismático com dimensões de $20 \mathrm{~cm} \times 10 \mathrm{~cm} \times 6 \mathrm{~cm}$. Em seguida as peças foram submetidas, com 7 dias cura, aos ensaios de resistência à compressão. Verificou-se qual traço de concreto com substituição do agregado miúdo pelo resíduo obteve maior resistência e submeteu-o, juntamente com o traço de referência, com 28 dias de cura ao ensaio de resistência à compressão, resistência à abrasão e absorção de água conforme as recomendações da ABNT NBR 9781/2013. A Figura 2 mostra a execução dos ensaios de resistência à compressão e resistência à abrasão das peças de concreto. 
Figura 2 - Ensaios de resistência nas peças: a) resistência à compressão; b) resistência à abrasão.

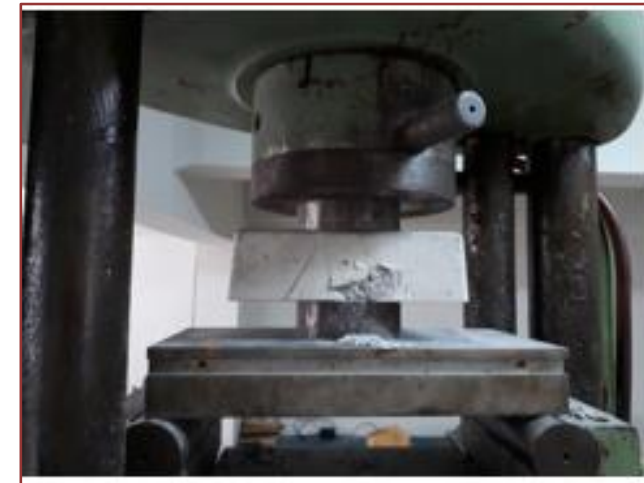

a)

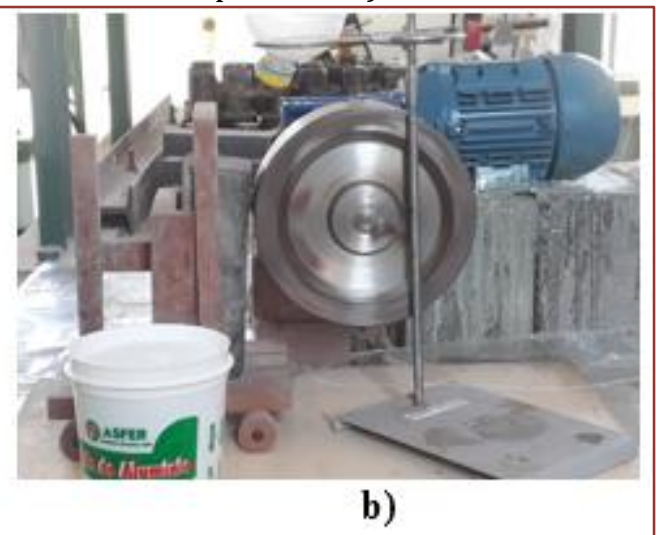

b)

Fonte: Autor, 2019.

\section{RESULTADOS E DISCUSSÕES}

A partir do ensaio de composição granulométrica dos agregados, avaliaram-se as curvas granulométricas dos materiais, atentando-se para as zonas limites impostas pela ABNT NBR 7111/2009. De acordo com a norma, para o agregado ser utilizado na produção de concreto, é necessário estar enquadrado dentro dos limites estabelecidos. A Figura 3 apresenta as curvas granulométricas dos agregados miúdos utilizados.

Figura 3 - Curvas granulométricas dos agregados miúdos.

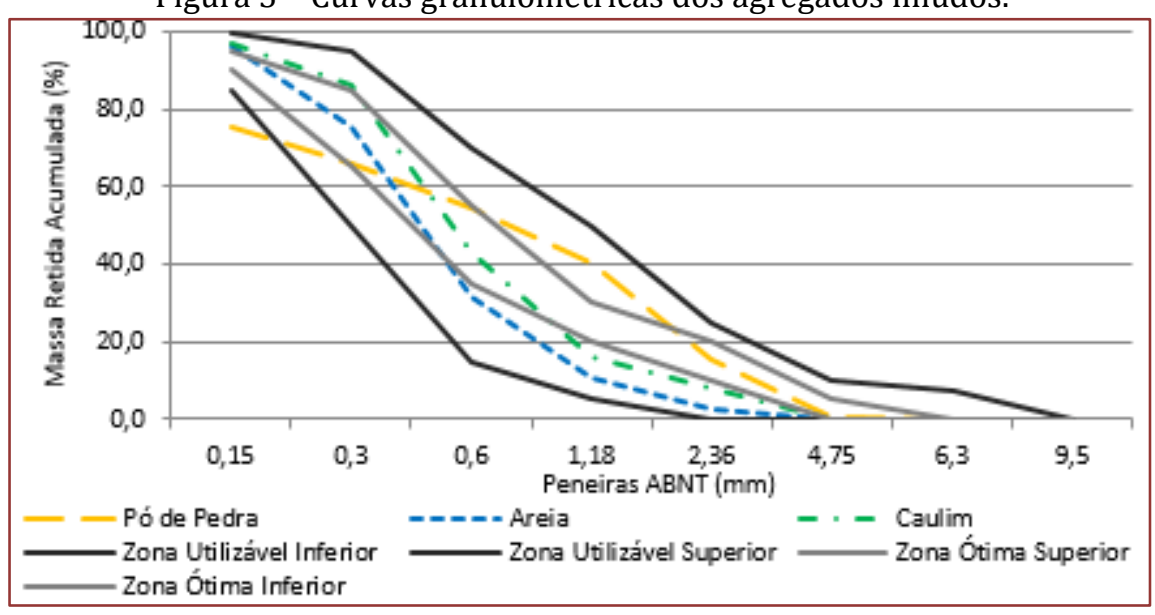

Fonte: Autor, 2019.

Observa-se que todas as curvas enquadraram-se dentro dos limites definidos pela norma, tornando-os viáveis as suas aplicações na produção do concreto.

A Figura 4 mostra a curva granulométrica da Brita 0. Constatou-se que a curva se enquadrou também dentro dos limites determinados pela norma. 
Figura 4 - Curva granulométrica do agregado graúdo.

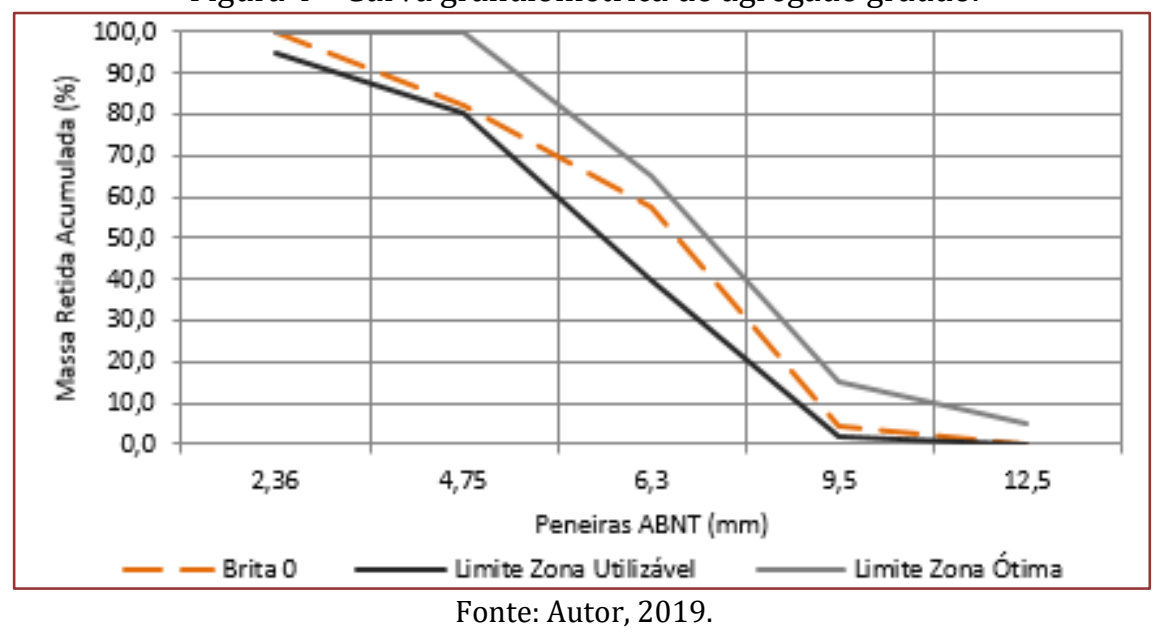

A Tabela 1 mostra o traço de referência, em massa, utilizado na produção do concreto. A partir do traço de referência, foram produzidos os traços com substituição do agregado miúdo pelo resíduo de caulim nas proporções já estabelecidas de $10 \%, 20 \%$ e $30 \%$.

Tabela 1 - Traço de referência utilizado para a produção do concreto.

\begin{tabular}{|c|c|c|c|}
\hline Cimento & Agregado miúdo & Agregado graúdo & Água \\
\hline 1 & 1,8 & 2,8 & 0,6 \\
\hline \multicolumn{3}{|c|}{ Fonte: Autor, 2019. }
\end{tabular}

A Tabela 2 mostra os valores de resistência à compressão dos traços de referência e com substituições do agregado miúdo pelo resíduo aos 7 dias de cura.

Tabela 2 - Valores de resistência à compressão das peças aos 7 dias.

\begin{tabular}{|c|c|}
\hline Traço & $\begin{array}{c}\text { Resistência Característica à } \\
\text { Compressão (MPa) }\end{array}$ \\
\hline REF & 38,5 \\
\hline $10 \%$ & 29,01 \\
\hline $20 \%$ & 27,01 \\
\hline $30 \%$ & 21,21 \\
\hline & Fonte: Autor, 2019.
\end{tabular}

Analisando os resultados percebe-se que a resistência diminuiu conforme aumentou a quantidade de resíduo na mistura do concreto. Dos traços com as substituiç̃ões o que apresentou melhor resultado foi o de $10 \%$ de substituição, com isso submeteu este traço e o traço de referência aos demais ensaios supracitados, com 28 dias de cura.

Os valores de resistência características à compressão dos pavers aos 28 dias de cura estão dispostos na Tabela 3. 
Tabela 3 - Valores de resistência à compressão das peças aos 28 dias.

\begin{tabular}{|c|c|}
\hline Traço & $\begin{array}{c}\text { Resistência Característica à } \\
\text { Compressão }(\mathrm{MPa})\end{array}$ \\
\hline REF & 41,71 \\
\hline $10 \%$ & 36,21 \\
\hline
\end{tabular}

Fonte: Autor, 2019.

Análogo aos resultados com 7 dias de cura, as peças de concreto com 10\% de substituição apresentaram menor resistência do que as peças sem a utilização do resíduo, apresentando uma redução de 13,19\% aos 28 dias. Mesmo com esta redução, o concreto obteve resistência superior ao limite mínimo para tráfego leve (35 MPa) exigido pela ABNT NBR 9781/2013.

Os valores de absorção de água das peças de concreto ensaiadas estão apresentados na Tabela 4.

Tabela 4 - Absorção de água das peças.

\begin{tabular}{|c|c|c|c|}
\hline Traço & Peças & $A(\%)$ & A (\%) \\
\hline \multirow{3}{*}{ REF } & 1 & 3,54 & \multirow{3}{*}{3,75} \\
\hline & 2 & 3,82 & \\
\hline & 3 & 3,88 & \\
\hline \multirow{3}{*}{$10 \%$} & 1 & 5,22 & \multirow{3}{*}{4,79} \\
\hline & 2 & 4,15 & \\
\hline & 3 & 5,00 & \\
\hline
\end{tabular}

Fonte: Autor, 2019.

Observando os resultados, constatou-se que os o concreto de referência e com substituição apresentaram valores médios de absorção menor que 6\% e valores individuais menores do que 7\%, limites máximos impostos pela ABNT NBR 9781/2013, tornado viável a substituição de $10 \%$ da areia e pó de pedra pelo resíduo do caulim.

Levando em consideração que a absorção do concreto e sua porosidade são propriedades diretamente proporcionais, pode-se afirmar que a presença do resíduo do caulim deixa o concreto mais poroso, influenciando negativamente na durabilidade e resistência dos pavers.

A Tabela 5 mostra os resultados da resistência à abrasão dos pavers. 0 resultado da resistência à abrasão é dado pela soma da dimensão da cavidade na peça com o fator de calibração do equipamento, conforme especificação da ABNT NBR 9781/2013.

Tabela 5 - Resistência à abrasão das peças.

\begin{tabular}{|c|c|c|}
\hline \multirow{3}{*}{ Traço } & Cavidade $(\mathrm{mm})$ & Cavidade Média $(\mathrm{mm})$ \\
\cline { 2 - 2 } REF & 8,41 & \\
& 8,44 & \multirow{2}{*}{8,4} \\
\cline { 2 - 2 } $10 \%$ & 8,38 & \\
& 7,88 & \multirow{2}{*}{9,0} \\
\cline { 2 - 2 } & 9,57 & 9 \\
\cline { 2 - 2 } & 9,54 & \\
\hline \multirow{2}{*}{ Fonte: Autor, 2019. }
\end{tabular}

Observa-se que as peças com substituição de $10 \%$ do agregado miúdo pelo resíduo apresentaram valores muito próximos ao concreto de referência. Os resultados obtidos estão muito abaixo dos valores máximos de cavidade determinados pela norma, que são de $23 \mathrm{~mm}$ para tráfego leve e $20 \mathrm{~mm}$ para tráfego pesado, atestando uma ótima resistência à abrasão das peças tanto para o traço de referência quanto para o traço com utilização do resíduo de caulim.

\section{CONSIDERAÇÕES FINAIS}

Após analisar a resistência à compressão das peças com 7 dias de cura, verificou-se que com o aumento das proporções de substituição do agregado miúdo pelo resíduo, houve uma redução na resistência das 
peças. Diante disso, viu-se que o traço com $10 \%$ de substituição apontou um melhor valor de resistência à compressão nas idades iniciais, em relação aos que portavam o resíduo de caulim em sua composição.

Aos 28 dias, viu-se que as peças com 10\% de caulim apresentaram resistência à compressão acima de 35 MPa, atendendo as especificações da ABNT NBR 9781/2013, estando aptos para a sua utilização na fabricação de peças para pavimento intertravado solicitações de pedestres e veículos leves. Contudo, semelhante às peças com 7 dias de cura, essas ainda apresentam valores de resistência à compressão inferiores em relação ao concreto convencional.

Tratando da absorção de água, o traço de referência e o traço de substituição, na proporção de $10 \%$, do agregado miúdo pelo resíduo de caulim, exibiram valores inferiores àqueles exigidos pela NBR 9781 (ABNT, 2013), que são 6\% para valores médios e $7 \%$ para absorções individuais, atendendo às especificações da norma e tornando viável a sua utilização.

Quanto à resistência a abrasão, apesar da realização deste ensaio ser facultativa, é importante a sua verificação para analisar a durabilidade das peças de concreto que estaram sujeitas às solicitações de veículos e intempéries do meio que estará inserido. Analisando os resultados, viu-se que o traço com $10 \%$ de substituição, além do traço de referência, apresentaram baixos valores de cavidade, estando aptos para serem utilizados até mesmo em pavimentos com solicitações de tráfego pesado.

Logo, tem-se que a produção de peças para pavimento intertravado com substituição de $10 \%$ do agregado miúdo pelo resíduo de caulim mostrou-se aceitável, atendendo aos parâmetros exigidos pela norma e contribuindo para a redução de impactos causados pela disposição desse rejeito na natureza, acarretando em benefícios para a sociedade e o meio ambiente.

\section{REFERÊNCIAS}

[1] Anepac. Associação Nacional das Entidades de Produtores de Agregados para Construção. 0 mercado de agregados no Brasil. São Paulo, 2015. 11 p.

[2] Associação Brasileira de Normas Técnicas. NBR 9781: Peças de concreto para pavimentação: Especificação e métodos de ensaio. Rio de Janeiro, 2013.

[3] ___. NBR 7211: Agregados para concreto: Especificação. Rio de Janeiro, 2009.

[4] _ _ _ NBR NM 248: Agregados: Determinação da composição granulométrica. Rio de Janeiro, 2003.

[5] ___ _ NBR NM 45: Agregados: Determinação da massa unitária e do volume de vazios. Rio de Janeiro, 2006.

[6] ___ NBR NM 52: Agregado miúdo: Determinação da massa específica e massa específica aparente. Rio de Janeiro, 2009.

[7] _. NBR NM 53: Agregado graúdo: Determinação de massa específica, massa específica aparente e absorção de água. Rio de Janeiro, 2009.

[8] Barbosa, A. A. et al. Aproveitamento do resíduo de caulim na produção do concreto sem fins estruturais. In: Congresso Brasileiro de Gestão Ambiental, 7., Campina Grande. Anais... Campina Grande: ConGea, 2016.

[9] Knapton, J. The design of concrete block roads. Londres: CCA, 1976.

[10] Mendonça, A. M. G. D. et al. Aproveitamento de resíduo de caulim na produção de blocos cerâmicos. In: Congresso Brasileiro de Gestão Ambiental, 8., 2017, Campo Grande. Anais... Campo Grande: Ibeas, 2017.

[11] Resende, M. L. S. et al. Utilização do resíduo de caulim em blocos de vedação. Revista Escola de Minas, Ouro Preto, v. 61, n. 3, p. 285-290, 2008.

[12] Santos, A. Extração mineral de areias e seus impactos na territorialidade socioambiental: o caso de Feira de Santana - BA. In: Seminário Internacional Dinâmica Territorial e desenvolvimento Socioambiental, 7., 2015, Salvador. Anais... Salvador: Ucsal, 2015. 


\section{Capítulo 14}

Contribuição na melhoria do processo de tratamento do óleo de fritura em operação em Indústria Domissanitária

Ivan Xavier Lins

Flávia Moura de Moraes

Mohand Benachour

Resumo:Estimativas apontam que um litro de óleo de fritura descartado de forma inadequada contamina cerca de 20 mil litros de água. Por se tratar de um resíduo com capacidade de se tornar matéria-prima em diversos processos, a busca por novas técnicas para tratar este resíduo de forma mais eficiente, vem crescendo em todo o país, além de ser de suma importância ambiental. 0 presente resumo, realizado em uma indústria domissanitária, Recife/PE, teve como objetivo o desenvolvimento de técnicas de tratamento físico-químicos em óleo residual de fritura, coletados no estado de Pernambuco, envolvendo as seguintes etapas: gradeamento, para separação óleo de fritura bruto/partículados, e decantação, para separação do óleo de fritura pré-tratado (após gradeamento)/água. Pretende-se com o óleo tratado e as águas oriundos das operações unitárias de separação líquido/sólido e líquido/líquido, valorizá-los na forma de matérias primas para produção sustentável do sabão em barra e para alimentação das caldeiras de geração de vapor. Melhorias foram efetuadas tanto na etapa de gradeamento, permitindo reduzir a quantidade dos particulados no óleo de fritura bruto, passando de $20 \%$ para $35 \%(\mathrm{v} / \mathrm{v})$. Quanto na etapa de decantação de óleo de fritura prétratado/água, realizada em escala industrial, houve um aumento dos rendimentos de recuperação dos óleos passando de $59 \%$ para $70 \%(\mathrm{v} / \mathrm{v})$, depois das modificações propostas no processo de separação em escala indústrial de óleo de fritura prétratado/água, respectivamente. As modificações propostas, frutos da nossa contribuição durante o projeto, envolveram a redução das aberturas da grade de separação de óleo de fritura bruto/particulados (etapa de gradeamento) e inclinação aumentando sua capacidade quanto a saturação da tela e desenvolvimento de testes laboratoriais (em funil de separação) de recuperação de óleo do sistema óleo/emulsão/água que nortearam a melhoria do processo de separação óleos pré-tratados/água em tacho industrial $\left(25 \mathrm{~m}^{3}\right)$, obtendo um aumento na recuperação de óleo de 53,1\% para 73\%.

Palavras-Chave: Óleos de fritura, Separação sólido/líquido, Separação óleo/água, Meio ambiente, Sustentabilidade. 


\section{INTRODUÇÃO}

O aumento do uso do óleo de cozinha, frequentemente utilizado em frituras, cujo excessso de consumo pode causar danos a saúde humana e ao meio ambiente se descartado de modo inadequado (pelo ralo das pias), provocando assim o entupimento das tubulações nas redes de esgoto, aumentando em até $45 \%$ os seus custos de tratamento (TIWARI, 2018). Apesar de pesquisas já terem demonstrado que um litro de óleo de cozinha que rejeitado para o corpo hídrico contamina cerca de 20.000 litros de água, só agora os ambientalistas concordam que não existe um modelo de descarte ideal do produto, mas sim, alternativas de reaproveitamento do óleo de fritura para a fabricação de biodiesel, sabão e etc. (FILHO, 2018).

Os principais óleos e gorduras vegetais comercializados são: óleo de soja, canola, amendoim, girassol, óleo de milho, de arroz, de uva, óleo ou gordura de coco de babaçu, óleo ou gordura de coco, óleo ou gordura de palma, de palmiste, óleo de gergelim, óleo misto ou composto, óleo vegetal saborizado e azeite saborizado, óleo de oliva, azeite de dendê (CAMARGO, 2016).

Os efluentes líquidos ao serem despejados com os seus poluentes característicos causam a alteração de qualidade nos corpos receptores e consequentemente a sua poluição. Historicamente, o desenvolvimento urbano e industrial ocorreu ao longo dos rios devido à disponibilidade de água para abastecimento e a possibilidade de utilizar o rio como corpo receptor dos dejetos. 0 fato preocupante é o aumento tanto das populações quanto das atividades industriais e o número de vezes que um mesmo rio recebe dejetos urbanos e industriais, a seguir servindo como manancial para a próxima cidade ribeirinha (WU, 2018).

A poluição origina-se devido as perdas de energia, produtos e matérias-primas, ou seja, devido à ineficiência dos processos industriais. 0 ponto fundamental é compatibilizar a produção industrial com a conservação do meio ambiente que nos cerca. Somente a utilização de técnica de controle não é suficiente, mas é importante a busca incessante da eficiência industrial, sem a qual a indústria torna-se obsoleta e é fechada pelo próprio mercado. A eficiência industrial é o primeiro passo para a eficiência ambiental (GAGOL, 2015).

A poluição pelos efluentes líquidos industriais deve ser controlada inicialmente pela redução de perdas nos processos, incluindo a utilização de processos mais modernos, arranjo geral otimizado, redução do consumo de água incluindo as lavagens de equipamentos e pisos industriais, redução de perdas de produtos ou descarregamentos desses ou de matérias primas na rede coletora. A manutenção também é fundamental para a redução de perdas por vazamentos e desperdício de energia (WU, 2018).

Após a otimização do processo industrial, as perdas causadas pela poluição hídrica devem ser controladas utilizando-se sistemas de tratamento de efluentes líquidos (GAGOL, 2015).

Os processos de tratamento a serem adotados, as suas formas construtivas e os materiais a serem empregados são considerados a partir dos seguintes fatores: a legislação ambiental regional; o clima; os custos de investimento; os custos operacionais; a quantidade e a qualidade do lodo gerado na estação de tratamento de efluentes industriais; a qualidade do efluente tratado; a segurança operacional relativa aos vazamentos de produtos químicos utilizados ou dos efluentes; explosões; geração de odor; a interação com a vizinhança; confiabilidade para atendimento à legislação ambiental; possibilidade de reuso dos efluentes tratados (WU, 2018).

Óleos e graxas entram em contato com água em muitos processos industriais. A energia dissipada pelo processo, a presença de substâncias surfatantes e partículas sólidas fazem com que o óleo se apresente de várias formas nos efluentes líquidos. As formas mais comuns são: livre, disperso, emulsificado e dissolvido (MOTTA, 2015).

Segundo Silva (2018) e pode-se classificar a presença de óleo em solução aquosa sob quatro formas distintas: livre, disperso, emulsificado e solubilizado. 0 óleo livre representa as dispersões grosseiras constituídas por gotas com diâmetro superior à $150 \mu \mathrm{m}$. Este tipo de dispersão é facilmente removido por meio de processos convencionais de separação gravitacional. 0 óleo disperso, normalmente com diâmetros de gota entre 50 e $150 \mu \mathrm{m}$, também pode ser removido por processos gravitacionais. Finalmente, o óleo pode também estar solubilizado na água $(200 \mathrm{mg} / \mathrm{L})$ sendo extremamente difícil a sua remoção, requerendo o uso de processos químicos especiais tais como, a extração com solventes, e/ou o emprego do tratamento biológico.

Um decantador é uma unidade de separação gravimétrica comum na qual a separação de líquidos imiscíveis ou parcialmente imiscíveis é realizada (Figura 2). Amplamente utilizado em vários processos contínuos, por exemplo, como uma unidade de separação óleo/água, em um processo de tratamento de águas residuais, como uma unidade de separação de biodiesel/água. Existem vários fatores que afetam a 
eficiência de separação de um decantador, sendo necessária uma diferença de densidade suficiente entre dois líquidos, Parâmetros operacionais como composição da alimentação e taxa de alimentação aproximadamente constantes (CHONWATTANA, 2018).

Independente da forma como o éleo se apresenta, o descarte ou reinjeção da solução oleosa só é permitido depois que o óleo e os sólidos em suspensão são removidos. As concentrações máximas de óleo e sólidos pemitidas nos efluentes depende da legislação de cada país (MIGUEL, 2014). No Brasil, de acordo com a resolução no 393 do CONAMA (2007), indica que o valor de óleo no efluente é de até $29 \mathrm{mg} / \mathrm{L}$.

0 presente Artigo teve como objetivos desenvolver melhorias nos processos físicos e físico-quimicos do tratamento de óleos de fritura coletados no Estado de Pernambuco para inserção no processo de produção de sabão em barra em uma indústria domissanitaria.

\section{OBJETIVO}

O referido trabalho teve como objetivo desenvolver melhorias no que diz respeito aos processos físicos bem como os físico-químicos do tratamento aplicado ao óleo de fritura coletado no Estado de Pernambuco, Região Nordeste brasileira, para viabilizar a separação em três estágios água, óleo e impurezas com intensificação do processo produtivo do sabão em Indústria química de produtos domissanitário.

\section{METODOLOGIA}

A metodologia proposta apresenta as diferentes etapas empregadas na separação do óleo de fritura bruto (contendo material sólido particulado) e na separação do óleo de fritura pré-tratado/água. Esse material foi concebido inicialmente em escala laboratorial, em seguida partindo para aplicação em escala industrial.

\subsection{PROCESSO ATUAL DE TRATAMENTO DO ÓLEO DE FRITURA}

A seguir apresentamos na figura 1, o fluxograma onde as etapas são descritas, percorrendo o caminho do óleo de fritura, desde sua coleta até a fabricação do produto domissanitário sustentável, neste caso, o sabão em barra e reuso da água de separação em caldeiras de geração de vapor e de irrigação dos jardins localizados nos arredores interiores da indústria.

O fluxograma mostrado na figura 1, consiste nas etapas descritas: a) coletar o óleo de fritura em estabelecimentos que geram óleo de forma direta (bares, restaurantes, cantinas) ou indiretamente (pontos de entrega voluntários (PEV); b) remover as impurezas na forma de partículas sólidas $>5 \mathrm{~mm}$ por separação através da passagem do óleo bruto por um gradeamento; c) separar a água contida no óleo pósgradeamento em um decantador alimentado por um fluxo de vapor de água visando desestabilizar a emulsão água/óleo e separação posterior de água (fase inferior), partículas orgânicas (fase intermediária) e óleos (fase superior) por diferença de densidade; d) remover o odor e cor do óleo decantado (fase superior) empregando um filtro prensa. 0 óleo resultante desse processo segue como matéria-prima para produção de sabão sólido; e) encaminhar a água proveniente da decantação (teor de óleo significante) para estação de tratamento das águas oleosoas externa; f) lavar os coletores (confeccionados com PVC) de óleos de fritura; g) misturar a água oleosa (proveniente da lavagem dos coletores) com a água oleosa da etapa de decantação, para envio para estação de tratamento; h) armazenar as suspensões orgânicas (< 5 $\mathrm{mm}$ ), advindas do gradeamento, no tanque de armazenamento para tratamento externo a unidade fabril. 
Figura 1: Fluxograma do recebimento e tratamento do óleo residual de fritura.

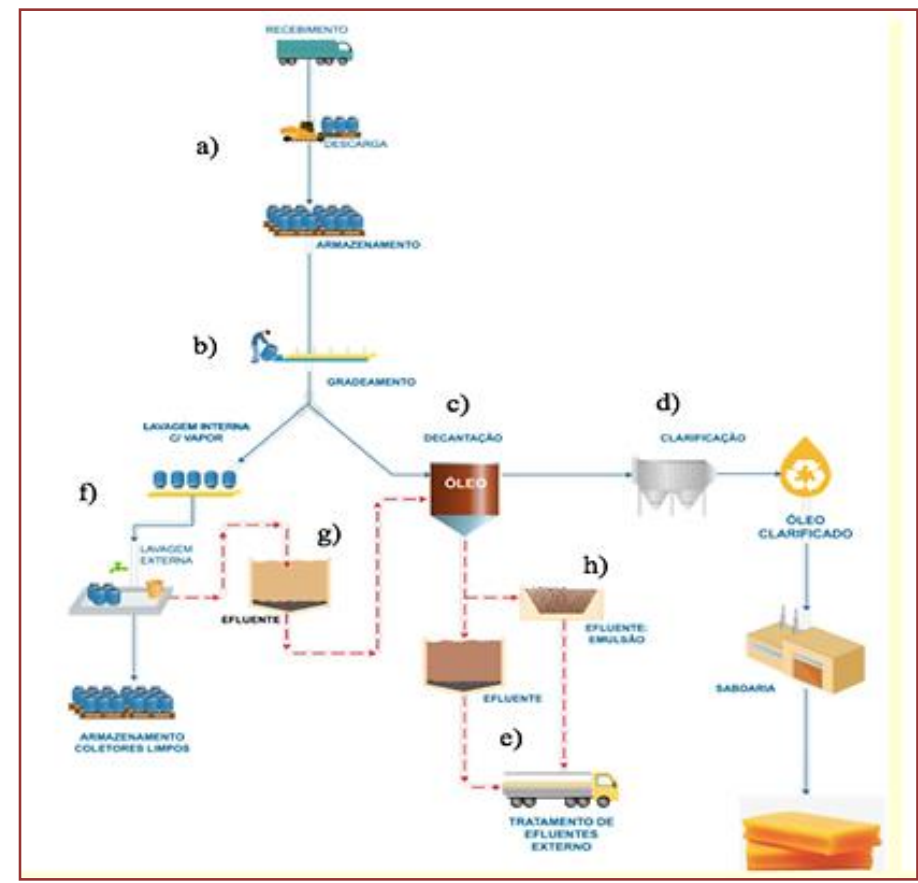

Fonte: Autor do Trabalho.

\subsection{PROCESSO PROPOSTO PARA TRATAMENTO DO ÓLEO DE FRITURA}

A seguir apresentamos a figura 2, onde trazemos, através do fluxograma ilustrativo, o processo de tratamento do óleo de fritura. Esse processo foi proposto após testes efetuados em escala laboratorial, em que pode ser visualizado uma melhoria dos rendimentos de separação líquido/sólido e líquido/líquido imiscíveis.

Figura 2: Fluxograma do recebimento e tratamento do óleo proposto.

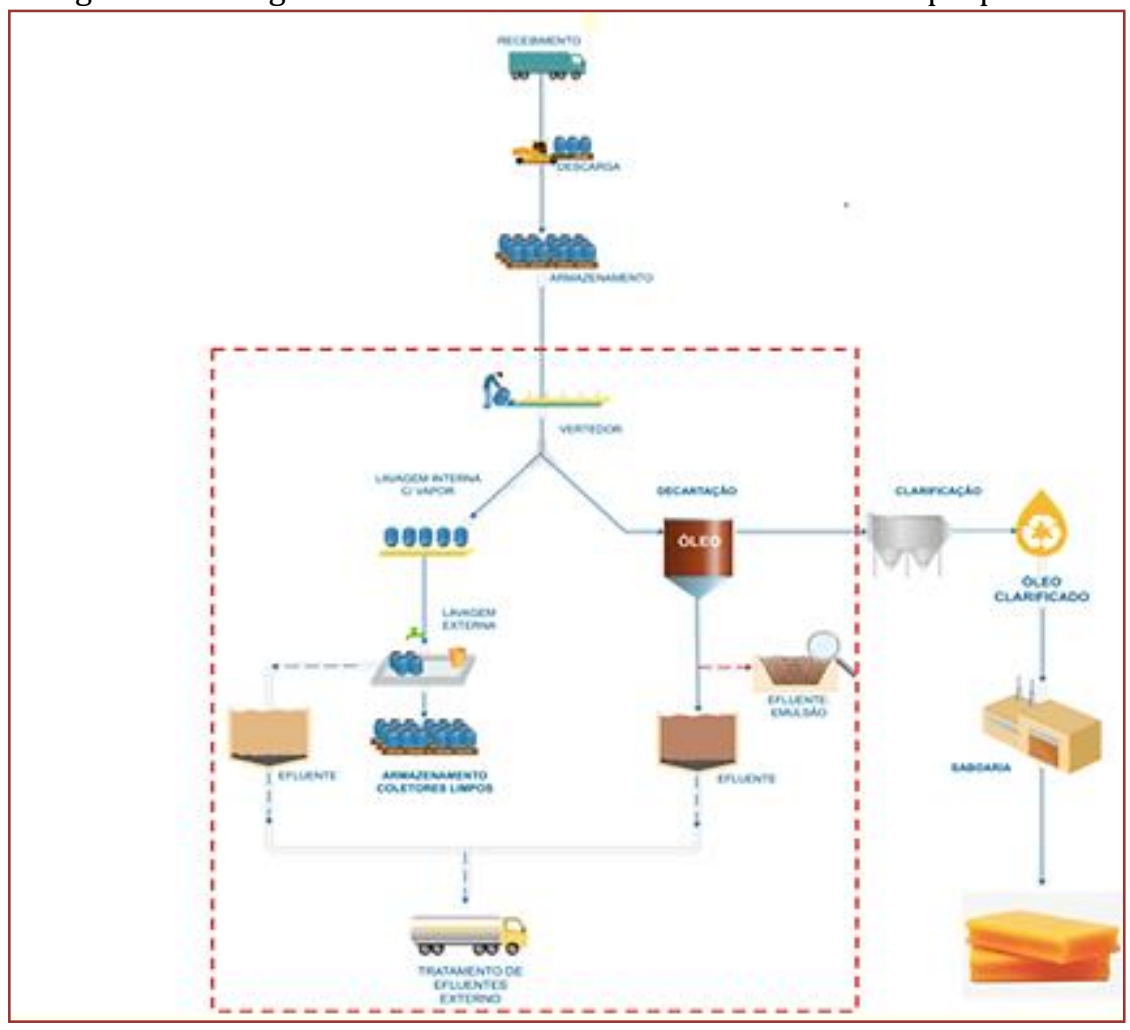

Fonte: Autor do Trabalho. 
O fluxograma proposto na figura acima apresenta melhorias nas etapas b e c, as demais etapas, a, d, e, f não apesentaram modificação.

Na etapa b), o processo de remoção de sólidos suspensos presente no tratamento, envolve o uso de uma peneira plana com abertura de $5 \mathrm{~mm}$, por onde o óleo escoa. Por conta da quantidade e do tipo de particulado que vem no óleo bruto, a peneira plana satura rapidamente, logo essa peneira sofreu uma modificação, que passa a ser uma chapa perfurada com furos de $3,2 \mathrm{~mm}$. A tela utilizada no processo de gradeamento, é do tipo malha inox de 5,08 mm, bitola de 18 BWG, área aberta de 64\%, tendo como área utilizada $2 \mathrm{~m}^{2}$, representada nas figuras 3 e 4 .

Figura 3: Gradeamento 5mm de abertura.

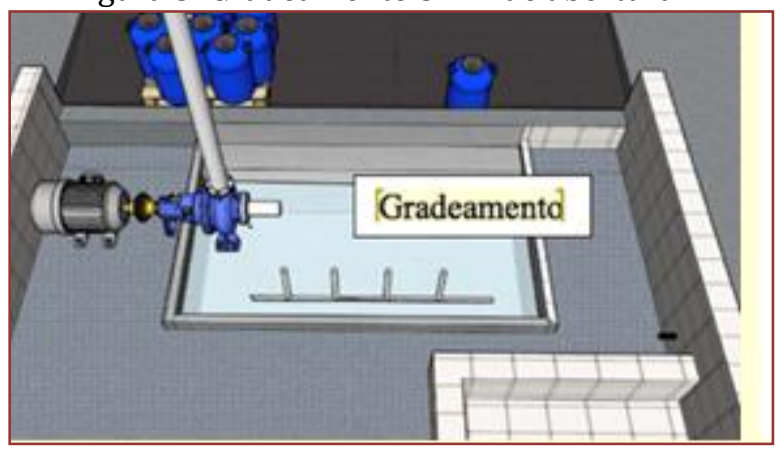

Fonte: Autor do Trabalho

Figura 4: Gradeamento (5mm de abertura) para remoção de particulados

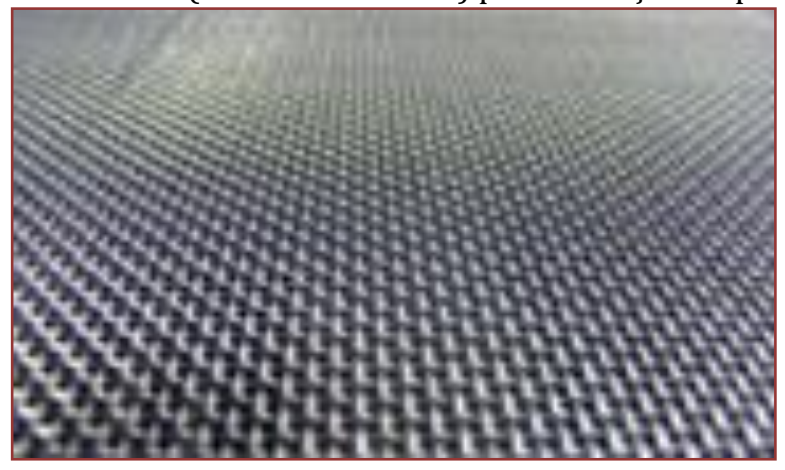

Fonte: Autor do Trabalho.

A fim de evitar a saturação da tela foram realizados testes em outro tipo de grade, onde foi levado em conta a eficiência de escoamento, saturação e limpeza da tela. Para o presente projeto foi proposto a utilização de chapas perfuradas inox de $3,2 \mathrm{~mm}, 3 \mathrm{~mm}$ de espeçura, área aberta de 40,35\%, com área utilizada $5 \mathrm{~m} 2$, e inclinação de 45o, como mostrado no desenho esquemático das figuras 5 e 6 , respectivamente.

Figura 5: Gradeamento inclinado (45o) 3,2 mm de abertura, para remoção de particulado sólido.

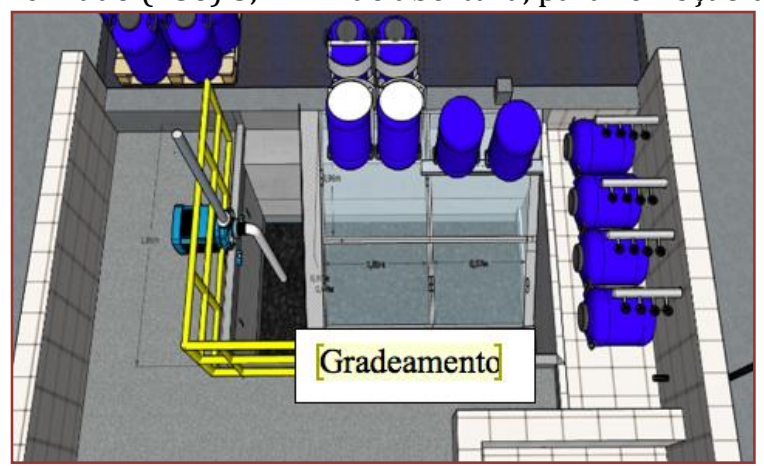

Fonte: Autor do Trabalho. 
Figura 6: Tela com perfurações em chapa metálica utilizada no gradeamento de 3,2 mm de abertura.

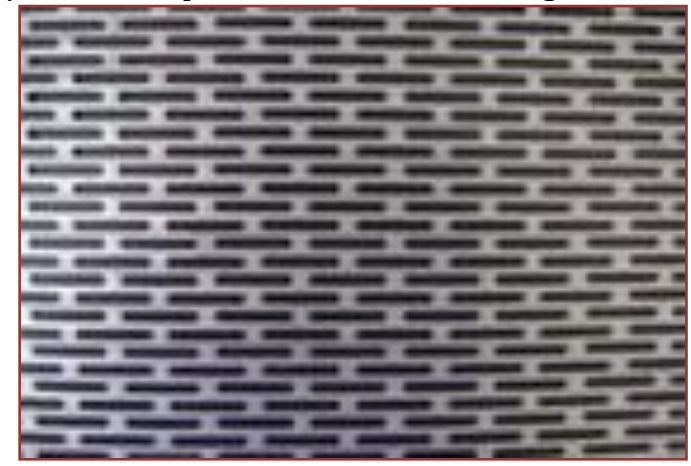

Fonte: Autor do Trabalho.

Na etapa c), a separação de sólidos presentes no óleo, é realizada por meio de uma decantação. Conforme adotado na indústria, o óleo de fritura bruto coletado é introduzido em um tanque industrial fechado (tacho) de $25 \mathrm{~m}^{3}$, adicionando-se percentuais adequados de substâncias químicas, a separação das fases, óleo, água e emulsão é observada.

Figura 7: Tacho industrial.

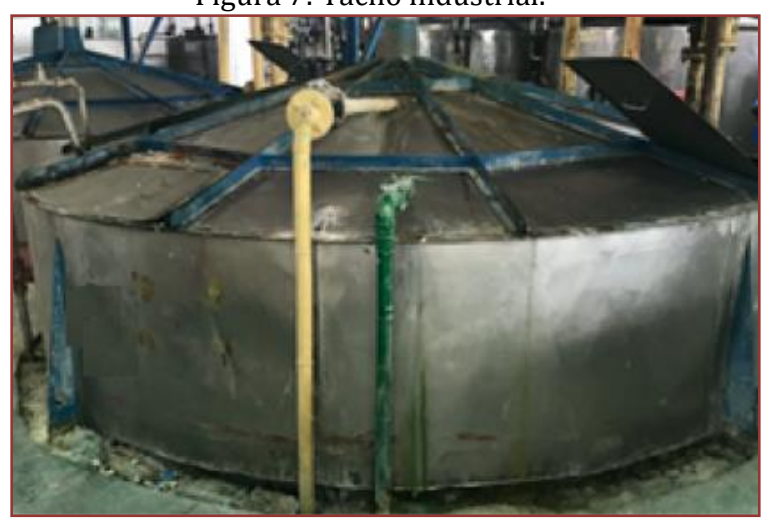

Fonte: Autor do Trabalho

Visando reproduzir o esquema de separação por decantação das 3 fases citadas acima em escala laboratorial, foi usado béquer $1 \mathrm{~L}$ para mistura e agitação contendo os óleos de fritura e respeitando a adição de produtos químicos nas suas proporções utilizadas no tanque de decantação industrial. Numa etapa seguinte, foi usado um funil de $500 \mathrm{~mL}$, para decantação respeitando o tempo de residência utilizado de 48 horas, conforme mostrado na Figura 8. Vale ressaltar que o óleo de fritura (após gradeamento) era inicialmente misturado com efluente da lavagem dos coletores. Uma amostra do óleo, sem a adição do efluente da lavagem dos coletores, foi submetida ao processo de separação em escala laboratorial, em um béquer de $1 \mathrm{~L}$ e seguindo o mesmo procedimento que foi aplicado a resultante da mistura do óleo de fritura (após gradeamento) e o efluente gerado na lavagem dos coletores. Após 48 horas de repouso, foi obtida uma separação de fases no funil, apresentada na Figura 9. 
Figura 8: Óleo misturado com efluente da lavagem dos coletores.

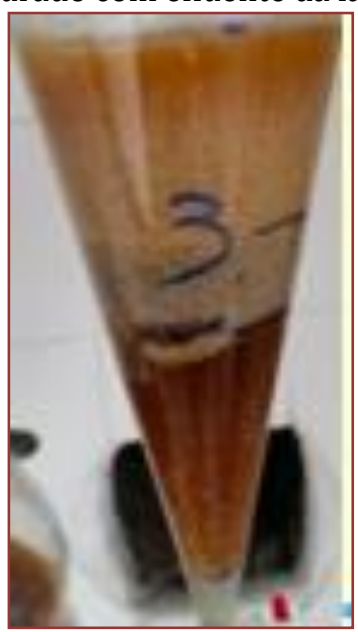

Fonte: Autor do Trabalho.

Figura 9 - Óleo sem mistura com efluente da lavagem dos coletores.

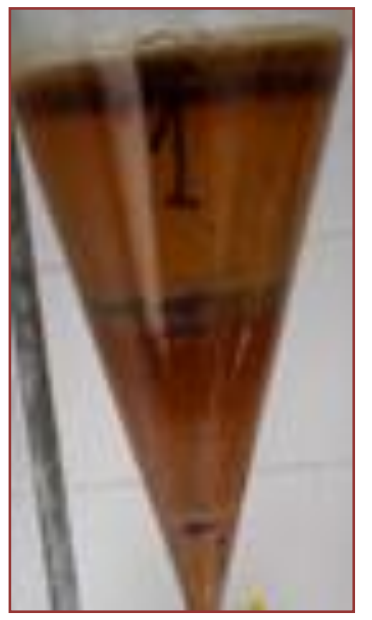

Fonte: Autor do Trabalho.

Com base nos resultados obtidos em escala laboratorial (no funil), o processo industrial foi alterado, o efluente da lavagem dos coletores não mais será misturado ao óleo de fritura.

\section{RESULTADOS}

Inicialmente, o gradeamento do óleo de fritura bruto foi efetuada usando uma grade de $5 \mathrm{~mm}$ plana (Figura 4). Nestas condições, foi removido em torno de $20 \%$ (v/v) de todos as partículas presente nesse óleo. Visando a elevação da taxa de remoção dos particulados do óleo de fritura bruto, uma alteração foi proposta no sistema de gradeamento, reduzindo o tamanho das aberturas conforme apresentado na Figura 6. Com essa mudança, em resultados preliminares, a taxa de remoção das partículas sólidas atingiu um valor em torno de $35 \%$ (v/v), melhorando assim a eficiência desta esta do processo.

Nos testes realizados em escala laboratorial foi observado que a mistura do óleo com o efluente da lavagem dos coletores, aumenta o percentual de fase emulsionada e diminui o percentual da fase oleosa se comparado com testes feitos sem a interferência do efluente na operação de decantação (Figura 8 e 9).

Quando se compara os resultados de recuperação de óleo em escala laboratorial para industrial se observa diferenças nos valores absolutos da taxa de recuperaçã, porém a tendência de elevação da taxa de recuperação de óleo de fritura, se confirma tanto na escala laboratorial quanto na industrial. 
Ao efetuar modificações no gradeamento para aumentar a remoção de sólidos presentes nos óleos de fritura, foi reduzida a abertura da grade em $36 \%$, assim a recuperação das partículas sólidas passou de $20 \%$ para $35 \%(\mathrm{v} / \mathrm{v})$;

Ao separar o efluente da lavagem dos coletores, evitando que o mesmo se misturasse ao óleo, foi obtido um aumento no rendimento do óleo de $49 \%$ para $61 \%$, e uma redução na geração de uma fase emulsionada em $72 \%$, quando se opera em escala laboratorial (funil);

Ao extrapolar a escala industrial (tacho de $25 \mathrm{~m}^{3}$ ), a recuperação da fase oleosa passou de 53,1\% para $71,0 \%$, e uma redução na geração da fase emulsionada de $67 \%$.

\section{REFERÊNCIAS}

[1] Camargo, R. P. L., Carrim, A. J. I., Franco, P. I. B. M., Antoniosi Filho, N. R. Assessment of the physicochemical suitability of oils and frying fats residuals for biodiesel production, Wastech, v. 4, n. 2, p. 1 - 8, 2016.

[2] Chonwattana, W., Panjapornpon, C., Tawai, A., Dechakupt, T. Model-based estimation and control of interface level in a two-phase vertical decanter: A case study of palm-oil/water system, Computers \& Chemical Engineering, v. 108, p. $372-381,2018$.

[3] Conama. Resolução No 393-do Conselho Nacional do Meio Ambiente, 2007.

[4] Filho, S.; Miranda, A.; Silva, T. Environmental and techno-economic considerations on biodiesel production from waste frying oil in São Paulo city, Journal of Cleaner Production, v. 183, p. 1034-1042, 2018;

[5] Gagol, M., Pryjazny, A., Boczka, G. Effective method of treatment of industrial effluents under basic $\mathrm{pH}$ conditions using acoustic cavitation, Chemical Engineering and Processing - Process Intensification, 2015.

[6] Miguel, A., Franco, D. Logística reversa do óleo de cozinha usado, FAESP, v. 9, p. 3 - 13, 2014.

[7] Motta, A. R. P., Borges, C. P., Kiperstok, A., Esquerre, K. Utilização de coalescedor com leito de resinas de trocas catiônicas para pré-tratamento de óleo emulsionado em efluentes líquidos, Engenharia Sanitária e Ambiental, v. 20 n. 2, p. $235-242,2015$.

[8] Silva, M., Sad, L., Pereira, R., Corona, J., Bassane, F. Study of the stability and homogeneity of water in oil emulsions of heavy oil, Fuel, v. 226, p. 278 - 285, 2018.

[9] Tiwari, A., Rajesh, V., Yadav, S. Biodiesel production in micro-reactors: A review, Energy for Sustainable Development, v. 43, p. 143 - 161, 2018

[10] Wu, S., Wallace, S., Brix, H., Kuschk, P. Treatment of industrial effluents in constructed wetlands: Challenges, operational strategies and overall performance, Environmental Pollution, v. 201, p. 107 - 120, 2018. 


\section{Capítulo 15}

\section{Questionário para diagnóstico do gerenciamento do óleo de cozinha residual}

\section{Ana Karoline Domiciano}

Giovana Ranthum Viechneiski

Nathana Cipriano Ulchak

Mariane Viviurka Fernandes

Silvia Carla da Silva André Uehara

\section{Tatiane Bonametti Veiga}

Resumo: No contexto dos resíduos sólidos, é considerável a parcela relacionada ao óleo residual de cozinha, comum em residências e estabelecimentos comerciais, que, se descartado de forma incorreta, pode acarretar danos ao meio ambiente. Dados informam que um litro de óleo polui 20.000 litros de água, além disso, a legislação brasileira estabelece limites para emissão de óleos vegetais e minerais. Diante dessa problemática, a pesquisa objetivou elaborar um questionário para ser aplicado junto aos estabelecimentos comerciais no município de Irati (PR) que gerem óleo residual de cozinha, com intuito de diagnosticar a situação de descarte do mesmo, quantidade gerada, tempo e modo de armazenamento, nível de conhecimento dos comerciantes quanto aos malefícios gerados com o descarte incorreto e as possíveis alterações no modo de descarte que o estabelecimento aceitaria realizar. 0 método de pesquisa utilizado foi o de Survey, que obtém dados e informações sobre as características e opiniões de público-alvo, através de um questionário como instrumento de pesquisa. Inicialmente foi realizado o levantamento dos estabelecimentos interessados em contribuir com a pesquisa, então aplicado o questionário como estudo piloto para observar total entendimento por parte dos entrevistados e imparcialidade das perguntas. Dos estabelecimentos participantes, os resultados indicaram uma geração média de $268 \mathrm{~L} /$ mês e $40 \%$ sujeitos indicaram obter um "bom" conhecimento e 40\% indicaram um conhecimento "razoável" sobre o descarte correto. Quanto aos danos causados pela prática incorreta é satisfatório o conhecimento, porém há um indicativo de um maior conhecimento pela contaminação de recursos hídricos e entupimento da rede de esgoto, comportamento esperado, devido às campanhas de conscientização abordar estes quesitos. 0 instrumento de pesquisa mostrou-se eficiente e os resultados evidenciaram que uma postura correta de seus empresários por todos dos entrevistados fazerem o descarte correto, e apesar dos dados coletados não serem representativos devido à grande quantidade de estabelecimentos prestadores de serviços de alimentação existentes no município de Irati, foi possível verificar a eficiência do instrumento de pesquisa, pois todos os sujeitos forneceram informações importantes para fundamentar a elaboração de um diagnóstico quanto a geração e manejo do óleo residual de cozinha dos estabelecimentos, podendo, este instrumento servir de base para outras pesquisas e plausível de adaptação devido especificidades regionais para obtenção de melhores informações.

Palavras-Chave: óleo de cozinha residual ${ }_{2}$ instrumento de pesquisa, descarte de óleo residual, contaminação ambiental, gerenciamento de resíduos. 
Os óleos, principalmente de soja, e seus derivados, como as gorduras, margarinas/cremes vegetais, são consumidos universalmente para a preparação de alimentos nos domicílios, estabelecimentos industriais e comerciais de produção de alimentos (Morás; Silva, 2009). De acordo com dados da Associação Brasileira das Indústrias de Óleo, o Brasil produz mais de três bilhões de litros de óleos vegetais por ano para consumo interno (Abiove; 2017).

Esses óleos, após serem degradados termicamente, quando descartados de maneira imprópria, causam danos ao meio ambiente, pois em contato com recursos hídricos, o óleo concentra-se na superfície, criando uma barreira sobrenadante que dificulta a entrada de luz e impede a oxigenação da água (Gaio et al, 2012), e, consequentemente, interfere na depuração da matéria orgânica e na cadeia trófica.

O óleo residual misturado com outros resíduos em encanamentos forma um bloco rígido de difícil desobstrução e ocasiona o entupimento na rede coletora, provocando o aumento da poluição e do custo de tratamento das águas (Caetano et al, 2010). Quando em contato com o solo, o óleo impermeabiliza a superfície impedindo que a água infiltre, fato que agrava problemas de enchentes, além de gerar graves problemas de higiene e mau cheiro (Castellanelli et al., 2007).

Segundo a Companhia de Saneamento Básico do Estado de São Paulo (Sabesp), um litro de óleo polui 20.000 litros de água (SABESP, 2007), sendo que Resolução do CONAMA no 430/2011 indica o limite legal de emissão de óleos vegetais e gorduras animais de até 50mg/L e óleo mineral de 20mg/L (Brasil, 2011).

A discussão referente a esse tema apresenta outras questões legais, como pode ser observado na Lei $n^{\circ}$ 9605/98, sessão III, Artigo 54, que considera como crime ambiental "causar poluição de qualquer natureza em níveis tais que resultem ou possam resultar em danos à saúde humana, ou que provoquem a mortandade de animais ou a destruição significativa da flora", sujeito a pena e multa aquele que fizer o "lançamento de resíduos sólidos, líquidos ou gasosos, ou detritos, óleos ou substâncias oleosas, em desacordo com as exigências estabelecidas" (Brasil, 1998, p. 9).

Diante dessa problemática, a pesquisa objetivou elaborar um questionário para ser aplicado junto aos estabelecimentos comerciais no município de Irati (Pr) que gerem óleo residual de cozinha, com intuído de diagnosticar a situação de descarte do mesmo, quantidade gerada, tempo e modo de armazenamento, nível de conhecimento dos comerciantes quanto aos malefícios gerados com o descarte incorreto e as possíveis alterações no modo de descarte que o estabelecimento aceitaria realizar, realizando a submissão do questionário ao Comitê de Ética em Pesquisa, nº 92984318.9.0000.0106, em conformidade com a Resolução 466/2012.

\section{METODOLOGIA}

A pesquisa foi realizada na cidade de Irati, situada na região Centro-Sul do Estado do Paraná, a $150 \mathrm{~km}$ de Curitiba, capital do Estado, com área territorial de 995,289 $\mathrm{km}^{2}$, com população estimada, em 2018, de 60357 habitantes (IBGE, 2019). As principais fontes econômicas da cidade consistem no comércio e serviços $(57,9 \%)$, indústria $(26,2 \%)$ e agropecuária $(15,9 \%)$, com produção principal de soja, feijão das águas e fumo (Prefeitura Municipal de Irati, 2018). 0 município possui 38 estabelecimentos industriais produtores alimentícios, de bebida e álcool etílico e 144 prestadores de serviços de alojamento, alimentação, reparo, manutenção, radiodifusão e televisão (Ipardes, 2018). 
Figura 1 - Localização Geográfica de Irati, Paraná, Brasil

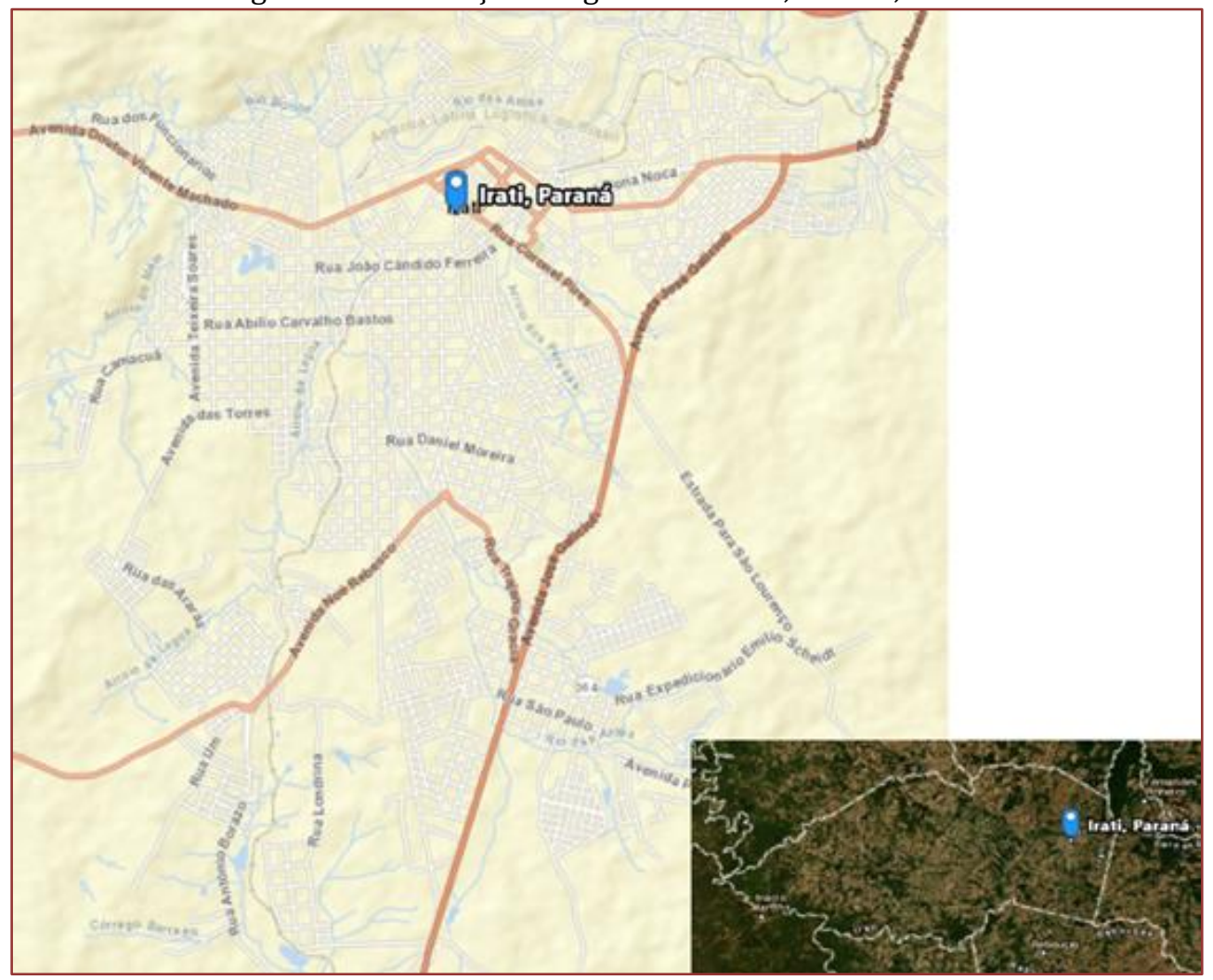

Fonte: ArcGIS Earth, 2019. Colagem: Autores, 2019.

Trata-se de um estudo descritivo, de caráter exploratório, com a utilização de procedimentos técnicos bibliográficos para construção de um aporte técnico e também da busca de informações a campo nos estabelecimentos produtores de óleo de cozinha residual, sendo a pesquisa descritiva importante para a ciência, pois a descrição é geralmente o primeiro e essencial passo para caminharmos em direção à compreensão (Volpato, 2015), principalmente quanto as condições socioeconômicas e ambientais em relação ao descarte desse resíduo.

0 método de pesquisa é o Survey, que obtém dados e informações sobre as características e opiniões de um grupo de pessoas, indicado como representante de uma público-alvo, utilizando um questionário como instrumento de pesquisa (Fonseca, 2002).

O questionário elaborado, inicialmente, foi estruturado com 12 questões, sendo 6 objetivas e 6 descritivas, para submissão ao Comitê de Ética da Universidade Estadual do Centro Oeste com a inserção das informações necessárias na Plataforma Brasil. Após a aprovação do questionário foi realizado um levantamento dos estabelecimentos foco desse estudo, sendo efetuado o contato com esses comércios para verificar seu interesse em contribuir com a pesquisa. 0 presente estudo foi realizado em três etapas, primeiramente por meio de redes sociais da empresa, seguido de ligação para agendamento da entrevista e finalmente a aplicação do questionário.

A cada modificação no questionário ele foi reaplicado nos estabelecimentos a fim de se obter um instrumento que busque o entendimento por parte dos entrevistados, visando construir um instrumento adequado para o levantamento de dados, possíveis de serem utilizados na elaboração de intervenções para a prevenção de danos ambientais provocados pelo resíduo foco desse estudo. Outra preocupação na construção desse estudo consistiu na imparcialidade para que nenhuma das suas respostas fossem induzidas pela pergunta. 


\section{RESULTADOS}

O questionário, objeto deste estudo, aprovado pelo Comitê de Ética da Universidade Estadual do Centro Oeste (Unicentro) teve sua versão inicial adaptada duas vezes após aplicação junto aos sujeitos em um estudo piloto, mantendo as ideias iniciais das informações que desejavam ser obtidas, modificando apenas as palavras empregadas e o formato das perguntas em dissertativas ou objetivas, conforme notado a interpretação dos entrevistados e a dificuldade ou facilidade em argumentar sobre alguns temas.

Após aprovação do comitê, a versão final do questionário manteve 12 questões, sendo 6 perguntas objetivas quanto a realização do descarte do resíduo no estabelecimento e os conhecimentos dos sujeitos a respeito do descarte incorreto do mesmo, além de 6 perguntas abertas para melhor descrição e opinião referente aos assuntos, indicando a complementaridade entre a abordagem qualitativa e quantitativa para uma interpretação adequada da realidade (Flick, 2009), conforme o exposto no final deste capítulo.

A princípio as perguntas foram realizadas com 6 estabelecimentos comerciais de Irati, sendo eles lanchonete, food truck, restaurante, pastelaria e petiscaria, sendo todos foco desse estudo como geradores de óleo de cozinha residual. Todos os sujeitos assinaram o Termo De Consentimento Livre e Esclarecido (TCLE) exigido pelo comitê de ética. Ressalta-se que este termo concede direito de confiabilidade e desistência do participante em qualquer período antes da publicação dos dados. Um dos estabelecimentos entrevistados, após ter suas atividades encerradas, solicitou que as informações fornecidas não fossem utilizadas, sendo respeitada sua desistência na participação, passando então a ser contabilizado e analisado os dados de 5 estabelecimentos.

A partir do estudo piloto realizado para testar o referido instrumento, segundo as respostas dadas ao questionário, foi possível determinar que o tempo médio de armazenamento do óleo de cozinha residual no estabelecimento é de 19,2 dias, o modo de armazenamento mais utilizado são galões plásticos de tampa lacrável, sendo gerados em média 67 litros por semana de óleo de cozinha residual, equivalente a 268 litros/mês. Um dos estabelecimentos informou que realiza descarte incorreto de pequenas quantidades do resíduo na rede de esgoto devido a presença do mesmo nos utensílios de cozinha.

Entre os estabelecimentos, somente dois possuíam conhecimento de algum projeto de coleta e reciclagem de óleo de cozinha residual, porém nenhum deles participava ativamente. Os projetos citados foram AMASEG e EcoTroca.

A AMASEG é uma pequena fábrica de sabão ecológico, no Centro de Convivência de um dos bairros de Irati, com liberação da vigilância sanitária e bombeiros para produção e comercialização municipal de produtos saneantes que tem em sua composição o óleo de cozinha residual. O Projeto EcoTroca é uma iniciativa da Prefeitura Municipal da cidade, no qual os moradores realizavam a troca de material reciclável por alimentos, sendo que cada família podia trocar $3 \mathrm{~kg}$ de material reciclável, como arames, canos de PVC, ferros, fios, fogão, garrafas, geladeira, latas, livros, óleo de cozinha residual, papel, papelão, peças de ferro de veículos, embalagens pet, plásticos e vidros por $1 \mathrm{~kg}$ de alimento, entre feijão, hortaliças, legumes, pães e outros; o limite era de $20 \mathrm{~kg}$ de alimento por família.

Durante o ano de 2017, em parceria com a AMASEG, o projeto EcoTroca passou também a realizar a troca de óleo de cozinha residual por sabões, sendo que a cada $2 \mathrm{~L}$ de óleo entregue a família recebia uma barra de sabão de $250 \mathrm{~g}$. 0 projeto EcoTroca está funcionando, atualmente, somente em quatro pontos de troca: bairro Fragatas, Pedreira, Vila Matilde e Vila Raquel (Prefeitura Municipal de Irati, 2019). 0 projeto AMASEG segue ativo desde o ano de 2004, fazendo o recolhimento do resíduo em todos os bairros do município.

Para a pergunta de "Qual o nível de conhecimento que você avalia possuir quanto aos impactos causados pelo descarte incorreto do óleo?", o entrevistado poderia escolher entre as alternativas "Muito Bom, Bom, Razoável, Pouco ou Muito Pouco". Dos entrevistados, 40\% consideraram seu nível de conhecimento "Bom", $40 \%$ consideraram "Razoável" e $20 \%$ considerou "Pouco". Na sequência, a pergunta solicitava que o sujeito indicasse alguns dos danos que tivesse conhecimento, sendo encontrada as respostas apresentadas no gráfico 1. 
Gráfico 1. Resultados das indicações quanto aos danos que podem ser causados devido ao descarte incorreto do óleo residual de cozinha, segundo os sujeitos

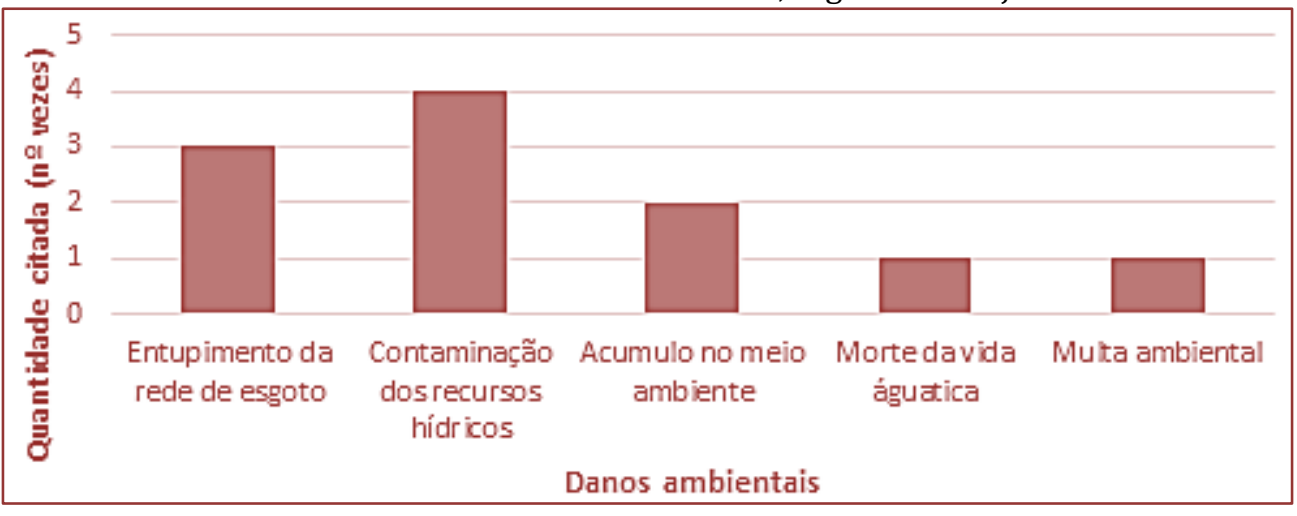

Fonte: Autores, 2019.

Dos danos causados pelo descarte incorreto do óleo de cozinha residual, $20 \%$ admitiu realizar a venda do resíduo devido as multas ambientais, $20 \%$ citou a perda da vida aquática, $80 \%$ relatou a contaminação dos corpos hídricos e $50 \%$ o entupimento da rede de esgoto. Porém, nenhum dos sujeitos soube relatar quanto as degradações do solo, acúmulo de vetores e desconforto ambiental devida geração de odor e má higienização. Tal comportamento era esperado, visto que a contaminação de recursos hídricos e danos na rede de esgoto causados por incrustações são os prejuízos mais citados em campanhas de coleta de óleo e campanhas de conscientização pelas prefeituras e companhias de saneamento, por estarem mais próximos dos hábitos diários da população

Nenhum dos estabelecimentos comerciais possuíam conhecimento do Projeto de Lei Municipal 181/2012 que dispõe sobre a Política Municipal de Saneamento Básico, no município de Irati, que tem como recomendações para o plano municipal de saneamento básico, no item 13. "Incentivar o aproveitamento do óleo vegetal através do armazenamento e coleta, bem como a produção de sabão" e item 14. "Incentivo ao consumo com responsabilidade ambiental onde a população conheça os procedimentos da empresa com relação ao destino dos resíduos", a fim de assumirem prática de preservação do meio ambiente (Irati, 2012).

Entre os entrevistados, 50\% afirmaram que sua aprovação seria indiferente, pois já são adotadas boas práticas de descarte. Então a situação do município continuaria a mesma e 50\% afirmaram que traria melhorias, destes $40 \%$ relataram como melhoria o maior envolvimento da prefeitura quanto a essa problemática, não só pela preocupação com o comércio, mas principalmente, com as residências que não possuem nenhum sistema de coleta e destinação adequados, $40 \%$ relataram que a destinação obrigatória auxiliaria no fortalecimento dos projetos municipais de coleta e reciclagem de óleo em produtos saneantes e $20 \%$ não quiseram discorrer sobre essa questão.

Caso houvesse maiores incentivos fiscais, financeiros e educacionais, os sujeitos poderiam indicar seis opções de atividades para o estabelecimento comercial aderir, sendo elas: realizar a venda do óleo para empresas de biodiesel e ração; realizar doações mensais a associações de artesão e fábricas de sabão; realizar a troca do óleo resíduo por sabão, em projetos sociais da prefeitura; ser patrocinador de projetos de educação e sensibilização ambiental em instituições de ensino no município; ser um "eco-ponto" para a comunidade, sendo sua responsabilidade a destinação correta do óleo entregue pela população; ser parceiro/colaborador na instalação e execução de programa de coleta seletiva de óleo no município. Para esse questionamento, foram encontradas diferentes respostas entre os sujeitos, conforme Gráfico 2. 
Gráfico 2. Resultados de incentivos ficais, financeiros e educacionais para trazer melhorias ao estabelecimento comercial, segundo os sujeitos

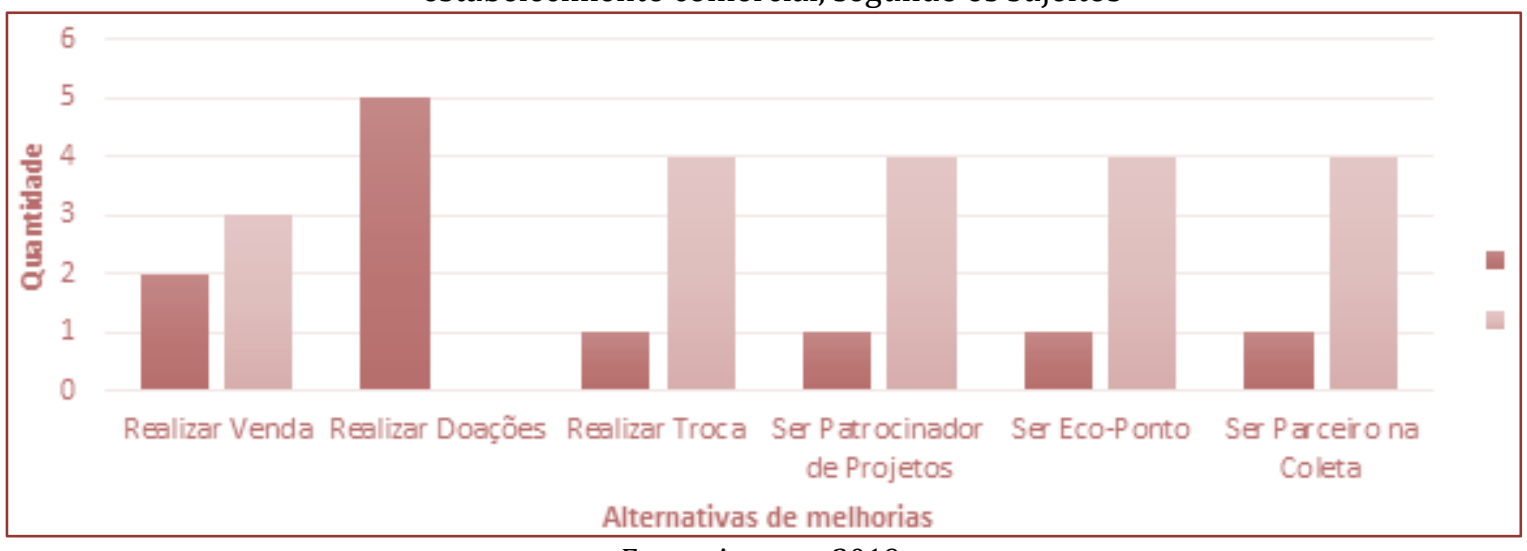

Fonte: Autores, 2019

O entrevistado poderia escolher quantas alternativas desejasse, como também poderia marcar todas ou nenhuma das alternativas, resultando em $40 \%$ dos sujeitos optariam por vender o óleo de cozinha residual, $100 \%$ aceitariam fazer doações mensais para instituições municipais de produção de sabão, 20\% fariam a troca do óleo residual por sabão em projetos sociais da prefeitura, $20 \%$ contribuiriam como patrocinadores de projetos de educação e sensibilização ambiental em instituições de ensino no município, 20\% auxiliariam na instalação e execução de programa de coleta seletiva de óleo e $20 \%$ aceitariam ser "eco-ponto" para a comunidade sendo sua responsabilidade a destinação correta do óleo entregue pela população.

\section{CONCLUSÕES}

A elaboração de um bom instrumento de pesquisa requer muita dedicação e atenção, pois ele irá refletir na qualidade dos dados que você irá obter. Um bom questionário precisa ter linguagem acessível a todos, clareza na pergunta e agilidade na resposta, visando uma maior adesão dos sujeitos. É necessário, também, planejamento para não comprometer o período da execução da pesquisa, pois a adequação do instrumento consome tempo e é tão complexo quanto a realização da pesquisa em si. A imparcialidade também foi fundamental para que as respostas não fossem induzidas as perguntas.

Apesar dos dados coletados não serem representativos devido à grande quantidade de estabelecimentos prestadores de serviços de alimentação no município de Irati, foi possível verificar a eficiência do instrumento de pesquisa, pois todos os sujeitos forneceram informações importantes para fundamentar a elaboração de um diagnóstico quanto a geração e manejo do óleo residual de cozinha dos estabelecimentos. Demonstraram, ainda, tranquilidade ao expor suas opiniões e sinceridade quanto a adesão de atividade, devido à grande variedade de respostas é notório que não houve indução por parte das perguntas, além disso o tempo para leitura e assinatura do TCLE junto com a leitura e resposta a todas as questões, não superou 20 minutos, sendo uma ferramenta de rápida aplicação que garante a não desistência dos entrevistados.

Os resultados do teste piloto já evidenciaram uma postura adequada dos sujeitos, considerando que $100 \%$ dos entrevistados faziam o descarte correto. Além disso, existência de iniciativa para destinações corretas para reinserção desse resíduo em um novo ciclo produtivo, reflete o interesse social por parte dos estabelecimentos em auxiliar o município na implantação e execução de algum sistema de coleta de óleo de cozinha residual. Tal disposição em auxiliar iniciativas de educação ambiental e destinação correta deve ser aproveitada para mudar hábitos da população, gerar e manter o bem-estar da populacional.

Em nova fase da pesquisa, o questionário obtido ao final desse estudo, está sendo aplicado a todos os estabelecimentos comerciais que gerem óleo de cozinha residual que estejam vinculados a associação comercial, industrial e empresarial do município de Irati e pretende-se estende-lo, se possível, a todos os demais comércios que se enquadrem nas características desejadas. 
De modo a elaborar um diagnóstico atualizado em relação ao descarte desse resíduo, fundamentar a elaboração e realização de intervenções e melhorias na gestão de resíduos urbanos do município e sanidade dos comércios, podendo, também, este instrumento servir de base para outras pesquisas e plausível de adaptação devido especificidades regionais para obtenção de melhores informações.

\section{AGRADECIMENTOS}

Á Fundação Araucária pela concessão de uma bolsa de Iniciação Científica.

Á orientação da Prfㅡㅡ Dre T.B.V.

Aos estabelecimentos comerciais pelo interesse em participar da pesquisa.

Aos colegas de orientação G.R., N.C.U., V.S., B.H. pelos comentários e sugestões durante a elaboração da pesquisa.

\section{REFERÊNCIAS}

[1] [1]. Associação Brasileira das Indústrias de Óleos Vegetais (ABIOVE). História. Disponível em: <http://www.abiove.org.br/site/index.php?page=historia\&area=My0xLTU=>. Acesso em 07 mar 2018.

[2] [2]. Brasil. Lei no 9605, de 12 de fevereiro de 1998. Dispõe sobre as sanções penais e administrativas derivadas de condutas e atividades lesivas ao meio ambiente, e dá outras providências.

[3] [3]. Conselho Nacional do Meio Ambiente (CONAMA). Resolução no 430, de 13 de maio de 2011. Dispõe sobre as condições e padrões de lançamento de efluentes, complementa e altera a Resolução no 357, de 17 de março de 2005.

[4] [4]. Caetano, R.; Gimenez, H. C.; Nascimento, A. C. M.; Nascimento, R.M. A logística reversa do óleo de fritura usado como solução para problemas ambientais. Logística reversa. Universidade Paulista. São Paulo. 2010.

[5] [5]. Castellanelli, C.; Mello, C. I.; Ruppenthal, J. E.; Hoffmann, R. Óleos comestíveis: o rótulo das embalagens como ferramenta informativa. I Encontro de Sustentabilidade em projeto do vale do Itajaí, 1. Santa Catarina. 2007. Disponível em: http://ensus2007.paginas.ufsc.br/files/2015/08/\%C3\%93leos-Comest\%C3\%ADveisO-R\%C3\%B3tulo-das-Embalagens-como-Ferramenta-I1.pdf. Acesso 25 de abril de 2019.

[6] [6]. Flick, U. Introdução à pesquisa qualitativa. 3 ed. Porto Alegre: Artmed. 2009.

[7] [7]. Fonseca, J. J. S. Metodologia da pesquisa científica. Fortaleza: UEC. 2002.

[8] [8]. Gaio, L. M.; Silva, J. S.; Rodrigues, J. P.; Ghesti, G. F. A educação ambiental na Engenharia e a reciclagem de óleo residual coletado: projeto de extensão Biogama. Universidade de Brasília. Brasília: Biblioteca Central. 2012.

[9] [9]. Índice Brasileiro De Geografia E Estatística (IBGE). Panorama Irati. 2019. Disponível em: < https://cidades.ibge.gov.br/brasil/pr/irati/panorama>. Acesso 12 mar 2019.

[10] [10]. Instituto Paraense De Desenvolvimento Econômico E Social (IPARDES). Município de Irati. Caderno Estatístico. Paraná. 2018.

[11] [11]. Irati. Câmara de Vereadores. Projeto de Lei 181/2012. Dispõe sobre a Política Municipal de Saneamento Básico. Disponível em: <file:///E:/Nova\%20pasta\%20(6)/0d4ba85ba7b99dba0f4444e943c289f2.pdf>. Acesso 02 fev.

[12] [12]. Morás, P. L.; Silva, J. D. Programa de reciclagem de óleo domésticos em Mandirituba, Paraná. 25ํㅡㄴ Congresso Brasileiro de Engenharia Sanitária e Ambiental. Recife. 2009.

[13] [13]. Prefeitura Municipal De Irati. História de Irati. Disponível em: <http://irati.pr.gov.br>. Acesso: 12 mar 2019.

[14] [14]. Prefeitura Municipal De irati. Notícias: Projeto EcoTroca retorna no próximo dia 12. Disponível em: <http://irati.pr.gov.br/noticiasView/2878_Projeto-Ecotroca-retorna-no-proximo-dia-12.html>. Acesso: 22 jul. 2019.

[15] [15]. Companhia de Saneamento Básico do Estado de São Paulo (SABESP). Efeitos De Óleos e Graxas para a Tratabilidade de Esgotos e Poluição Difusa. 2007.

[16] [16]. Volpato, G. L. O método lógico para redação cientifica. Revista Eletrônica de Comunicação, Informação e Inovação em Saúde, v. 9, n. 1, mar. 2015. 


\section{QUESTIONÁRIO PARA COMÉRCIOS GERADORES DE ÓLEO DE COZINHA RESIDUAL}

\section{Estabelecimento Comercial:}

\section{Sujeito:}

Função:

E-mail:

1. Qual a destinação do óleo de cozinha residual gerados no estabelecimento?

2. De que modo e por quanto tempo esse resíduo é armazenado no estabelecimento?

3. Você poderia estimar o volume de resíduo gerado por dia/semana/mês?

4. Ocorre o descarte de alguma quantidade de óleo residual na rede de esgoto?

5. Você tem conhecimento de algum projeto de coleta e reciclagem de óleo de cozinha residual realizado no município?

(_)Sim (_)Não

6. $\quad 0$ estabelecimento participa de algum projeto nessa área?

(_) Sim (_)Não

6.1. Se sim, qual? Por quanto tempo?

7. Qual o nível de conhecimento que você avaliar possuir quanto aos impactos causados pelo descarte incorreto do óleo:

(_) Muito Pouco

(_) Pouco

(_) Razoável

(_) Bom

(_) Muito Bom

8. Você pode citar alguns danos que podem ser causados devido ao descarte incorreto do óleo?

9. Você tem conhecimento do Projeto de Lei № 181/2012 que dispõe sobre a Política Municipal de Saneamento Básico, no município de Irati, que tem como recomendações para o plano municipal de saneamento básico, no item 13. "Incentivar o aproveitamento do óleo vegetal através do armazenamento e coleta, bem como a produção de sabão" e item 14. "Incentivo ao consumo com responsabilidade ambiental onde a população conheça os procedimentos da empresa com relação ao destino dos resíduos", a fim de assumirem prática de preservação do meio ambiente?
(_) Sim
(_)Não 
10. A aplicação dessa Lei propiciaria melhorias aos estabelecimentos comerciais? Por que?

11. Se em seu estabelecimento de trabalho tivesse um "Eco-Ponto" para descarte adequando do óleo de cozinha residual, você incentivaria seus clientes a levarem o óleo de cozinha residual de suas casas até o ponto de coleta?
(_) Sim
(—)Não

12. Se houvesse maiores incentivos ficais, financeiros e educacionais, quais das alternativas você acredita trazer melhorias e aderiria ao estabelecimento comercial:

(_) Realizar a venda do óleo para empresas de biodiesel e ração

(_) Realizar doações mensais a associações de artesão e fabricas de sabão

(_) Realizar a troca do óleo resíduo por sabão, em projetos sociais da prefeitura

(_) Ser patrocinador de projetos de educação e sensibilização ambiental em instituições de ensino no município

(_) Ser um eco-ponto para a comunidade, sendo sua responsabilidade a destinação correta do óleo entregue pela população

(_) Ser parceiro/colaborador na instalação e execução de programa de coleta seletiva de óleo no município 


\section{Capítulo 16}

Otimização e conservação dos recursos hídricos por meio de práticas de reuso de águas residuarias em oficina de manutenção de locomotivas

\section{Demerson Fernandes Silva}

Dirceu José dos Santos Júnior

Halison Salis Eustáquio

Páglia Silva Lopes Santos

Hygor Aristides Victor Rossoni

Resumo: 0 estudo de caso apresenta um levantamento de como a Empresa Ferrovia Centro Atlântica S/A- FCA está gerenciando o uso da água em seus processos industriais por meio de controle de demanda e uso de tecnologias de aproveitamento de água na Oficina de Manutenção de Locomotivas em Divinópolis, MG. Foram realizadas pesquisas de campo e consultas de dados internos sobre o consumo de água de abastecimento geral e por setores dentro da oficina com vistas à identificação das atividades industriais que mais demandam água, o volume de efluente gerado e tratado na Estação de Tratamento de Efluentes, a fim de verificar a otimização do recurso hídrico via prática de reuso desse efluente. Em função dos dados pode-se constatar que a solução proposta representa ser sustentável, viável e estratégica para a empresa, uma vez que colabora para o uso racional e para a competitividade da mesma, gerando maior autonomia e minimização dos custos. Os resultados refletiram em economia real de consumo de água de abastecimento da oficina em 11,16\%, advindos da implantação do reuso nas áreas de Lavação de Peças de Componentes e Lavação de Locomotivas da área de Reparo Pesado, que atingiu o patamar de 99,57\% de redução de consumo anual destas respectivas áreas.

Palavras-chave: reaproveitamento; usos múltiplos da água; tratamento e manejo; efluentes; manutenção de veículos ferroviários. 


\section{INTRODUÇÃO}

Atualmente, a indústria nacional está submetida a dois grandes instrumentos de pressão. De um lado, as imposições do comércio internacional com vistas à melhoria da competitividade e do outro, as questões ambientais e as condicionantes legais de gestão de recurso hídrico (SEBRAE 2017).

Para se adaptar a este novo cenário, o setor industrial vem aprimorando seus sistemas de gestão ambiental via implantações de sistemas e procedimentos da gestão de demanda de água, minimização da geração de efluentes e reaproveitamento de águas residuárias, que segundo Hespanhol (2008) além de estimular o uso racional da água, promove práticas mais eficientes sob o aspecto técnico e ambiental, como o reuso.

Até o momento, não existe uma regulamentação para o reuso industrial de efluentes no Brasil. A única orientação nacional vigente é a norma brasileira NBR 13.969, criada em 1997, que estabelece quatro classes de reuso e aponta possíveis aplicações para cada classe, bem como recomenda limites para os parâmetros de qualidade considerados relevantes, de acordo com o uso pretendido (ABNT, 1997).

Segundo Macuso \& Santos (2003), o reuso industrial de efluentes também pode ser dividido em classes, considerando a proveniência do mesmo. 0 macro externo é quando o efluente a ser reutilizado é proveniente de esgoto municipal ou de uma estação de tratamento de efluente de outra indústria. 0 macro interno é proveniente de outras atividades na própria indústria, podendo ser dividido em duas subclasses: reuso direto (em cascata) é utilizado diretamente em outra etapa, sem qualquer tratamento prévio, e reuso de efluente tratado, onde o efluente é submetido a um tratamento previamente à reutilização em outro setor da indústria.

Objetiva-se com este trabalho, otimizar a demanda dos recursos hídricos na busca da sustentabilidade industrial e competitividade por meio do sistema de reuso. Com autonomia e minimização dos custos referente a este processo na oficina de manutenção de Locomotivas da Ferrovia Centro Atlântica S/A FCA em Divinópolis, MG, que realiza todas as manutenções necessárias para que os equipamentos e veículos ferroviários estejam confiáveis e disponíveis para o transporte ferroviário de carga de seus clientes.

\section{METODOLOGIA}

O estudo de caso apresenta uma análise da conservação e otimização do reuso macro interno de efluente industrial tratado, na Oficina de Manutenção de Locomotivas da Ferrovia Centro Atlântica S/A. Os dados utilizados foram obtidos a partir de levantamento de campo e consulta a informações e base de dados da empresa objeto da pesquisa.

O desenvolvimento do trabalho foi pautado no diagnóstico da demanda e consumo de água de abastecimento da oficina identificando as áreas chave que demandam mais água em suas atividades e passíveis de utilização de águas residuárias, bem como na avaliação da otimização gerada pela implantação do sistema de reuso. A água consumida pela empresa é obtida de duas formas, conforme demonstra a Figura 1.

Figura 1: Fluxo de consumo de água 51\% via concessionária e 49\% Poço Artesiano.

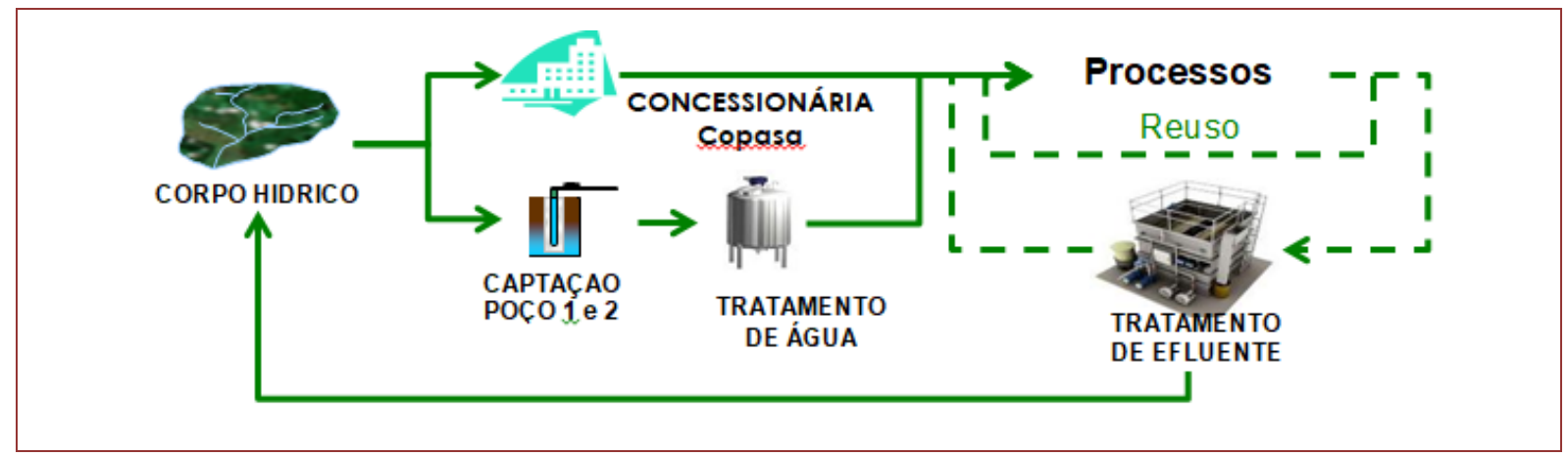

O abastecimento via concessionária é realizado por meio de 7 hidrômetros de entrada (HE). E por outro lado através dos 2 poços artesianos denominados como Poço 1 e Poço 2. Além de existir os hidrômetros de 
circulação (HC) anterior a cada área de consumo. Os dados coletados das leituras são analisados para levantamento do consumo e desvios relacionados a cada área. A quantidade de consumo de água em toda oficina é de $49,34 \mathrm{~m}^{3}$ dia.

Os efluentes gerados são tratados na Estação de Tratamento de Efluentes que possuem sistema físico químico e lodo ativado, sendo o volume médio de efluente diário tratado de $21 \mathrm{~m}^{3}$.

\section{RESULTADOS E DISCUSSÃO}

Os resultados obtidos neste trabalho evidenciam que a empresa registrava um alto consumo de água de abastecimento. Assim, instalou-se indicadores de acompanhamento mensal do consumo da oficina no ano de 2017, apurando por extratos, as áreas de maior demanda.

O consumo geral da oficina no ano de 2017 foi de $11.554,79 \mathrm{~m}^{3}$. 0 extrato objeto do estudo é o consumo de água de abastecimento nas atividades industriais. 0 acompanhamento do consumo viabilizou a identificação das áreas de maior demanda, sendo lavação de peças/Componentes $653,9 \mathrm{~m}^{3}$ ano e lavação de locomotivas de Reparo Pesado (setor de manutenções em Locomotivas maiores que demandam mais tempo) $510 \mathrm{~m}^{3}$ ano, conforme demonstrado na Figura 2.

Figura 2: Estratificação do consumo de água nova da oficina no ano de 2017.

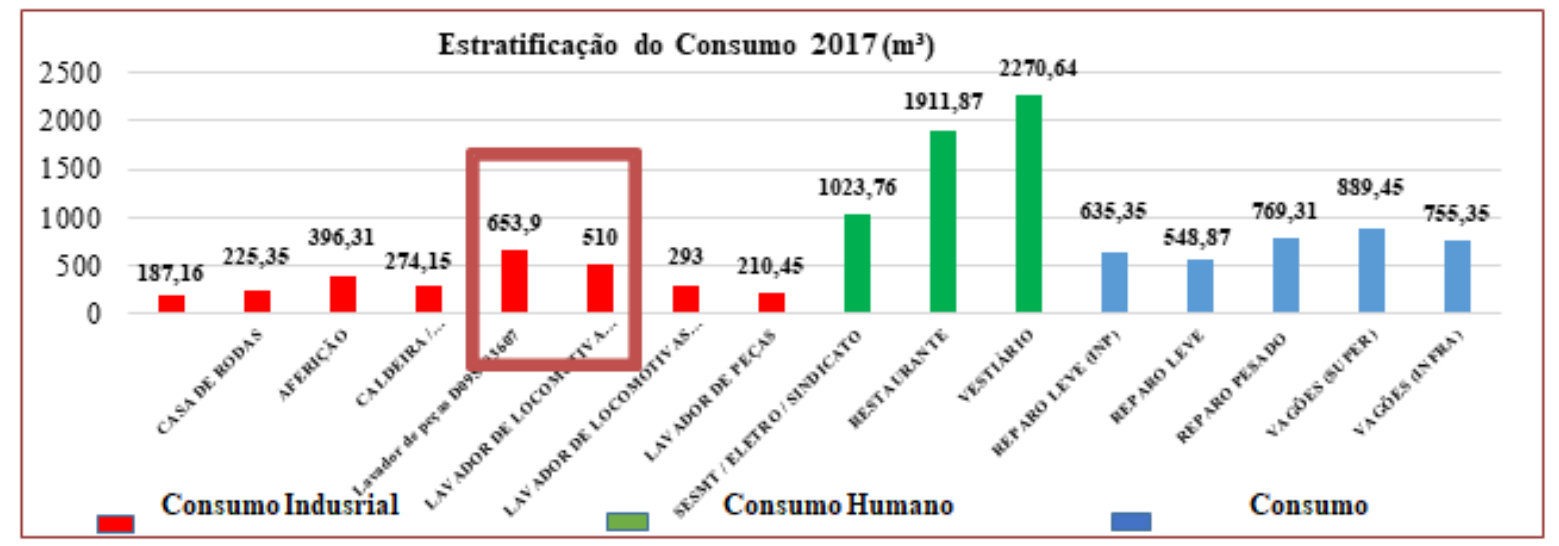

Em conjunto com os novos instrumentos de gestão dos recursos hídricos que estão sendo implantados na empresa, optou-se pela alternativa tecnológica para reuso do efluente tratado pela ETE por meio da implantação de um módulo de reuso. 0 equipamento é instalado na etapa final do processo, após o efluente ter sido tratado e possui uma vazão máxima de $10 \mathrm{~m}^{3} / \mathrm{h}$. 0 mesmo é composto por bomba de sucção, filtro sacola, lâmpada UV e painel de controle que garante a qualidade do efluente de reuso.

Os resultados da implantação do módulo de reuso refletiram positivamente em 2018.

Figura 3: Quadro comparativo consumo de água nova da oficina nos anos de 2017 e 2018.

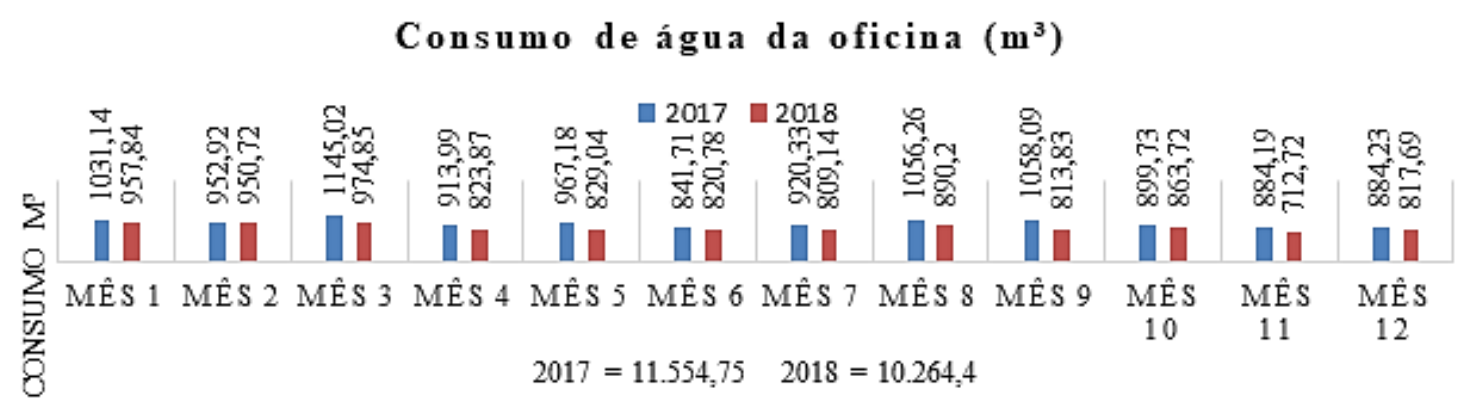


A Figura 3 demonstra que houve uma redução de $1.164 \mathrm{~m}^{3}$ para $4,94 \mathrm{~m}^{3}$ (lavador de peças/componentes: $3,4 \mathrm{~m}^{3}$ ano e lavação de locomotivas de reparo pesado: $1,54 \mathrm{~m}^{3}$ ano), reutilizando $1.290,39 \mathrm{~m}^{3} \mathrm{de}$ efluentes no ano.

\section{CONCLUSÕES OU CONSIDERAÇÕES FINAIS}

Com o presente estudo, pode-se concluir que a implantação do sistema de reuso colaborou com conservação dos recursos hídricos e sem dúvida mostrou-se uma decisão viável e estratégica para a empresa. A área objeto do estudo racionalizou o uso da água, otimizando o consumo em 99,57\% ano. Este resultado culminou na redução de $11,16 \%$ do consumo geral da oficina, além de proporcionar maior autonomia frente ao risco de uma futura restrição ou mesmo interrupção no abastecimento de água do setor industrial. A economia gerada possibilitará o retorno do investimento realizado em aproximadamente quatro anos. Diante deste resultado a empresa pretende levar a mesma tecnologia para outras áreas da oficina.

\section{REFERÊNCIAS}

[1] COPASA. Cia de Saneamento de Minas Gerais. Disponível em: http://mzweb.com.br/copasa/web/arquivos/COPASA_SPCM_17102006_port.pdf Acesso em: 03 de junho de 2019.

[2] SEBRAE. Manual de conservação e reuso da água na indústria. Disponível em: <http://www.sebrae.com.br/sites/PortalSebrae/bis/manual-de-conservacao-e-reuso-da-agua-naindustria,3aa6381b363dd510VgnVCM1000004c00210aRCRD> Acesso em: 18 de abril de 2019.

[3] HESPANHOL, I. Um novo paradigma para a gestão de recursos hídricos. Revista de Estudos Avançados, v. 22, n. 63, p. 131-157, 2008. Disponível em:

http://www.revistas.usp.br/eav/issue/view/751

[4] ABNT. Norma NBR 13969: Tanques Sépticos - unidades de tratamento complementar e disposição final dos efluentes líquidos - projeto, construção e operação. Associação Brasileira de Normas Técnicas, Rio de Janeiro, ABNT, 1997.

[5] ODPPES, R. J.; MICHALOVICZ, D. T.; BILOTTA, P. Reuso de água em indústria de fabricação de estruturas em concreto: uma estratégia de gestão ambiental. R. Tecnol. Soc., Curitiba, v. 14, n. 34, p. 82100, out./dez. 2018. Disponível em: https://periodicos.utfpr.edu.br/rts/article/download/7662/5399. Acesso em: 20 de abril de 2019.

[6] MANCUSO, P. C. S., SANTOS, H. F. COORD.: PHILIPPI, A. JR. Reúso de água. São Paulo: Editora Manole, 2003. 


\title{
Capítulo 17
}

\section{A logística reversa de embalagens de lubrificantes automotivos no Brasil: O cenário atual e as exigências da Política Nacional de Resíduos Sólidos}

\author{
Harley Moraes Martins \\ Michelle Ramos Cavalcante Fortunato \\ Gustavo Simas Pereira \\ Hudson Santos da Silva
}

Resumo: Esse artigo apresenta o cenário atual da implementação dos sistemas de logística reversa de embalagens de lubrificantes automotivos pós-consumo no Brasil. 0 estudo demonstra que a gestão desse tipo de resíduo ainda persiste como situação preocupante e que quase inexistiram avanços nas últimas décadas, mesmo após citação de sua obrigação formal no inciso IV do artigo 33 da Lei 12.305/2010. A Lei supracitada, que instituiu a Política Nacional de Resíduos Sólidos no Brasil, assim como seu Decreto Regulamentador (Decreto 7.404/2010) atribui aos entes participantes da cadeia produtiva de lubrificantes, a responsabilidade pela efetiva estruturação e implementação de sistemas de logística reversa de suas embalagens pós-consumo e define que tal estruturação deva ser feita através de acordos setoriais, sem estabelecer parâmetros específicos de controle da eficácia desses sistemas.

Nesse trabalho, o grupo de pesquisa retoma e atualiza os dados dos estudos de Martins (2005) e Martins (2014) sobre o Programa Jogue Limpo, instituído pelo Sindicato das Empresas Distribuidoras de Combustíveis e Lubrificantes (SINDICOM, atualmente denominado PLURAL). 0 trabalho atual avalia práticas vigentes e as relaciona com exigências da Política Nacional de Resíduos Sólidos, demonstrando os principais desafios para que tal logística reversa torne-se ambientalmente eficaz e economicamente viável.

A observância da Política e da realidade brasileira fomentam uma reflexão sobre o real comprometimento de todos para efetiva implementação da logística reversa dessas embalagens, que no contexto da gestão ambiental apresenta reiterados entraves, principalmente, de natureza operacional, logística e econômica.

Palavras-chave: Logística Reversa, Embalagens Lubrificantes, Reciclagem de Plástico, Plástico Pós-Consumo, Resíduos Sólidos. 


\section{INTRODUÇÃO}

O aumento de embalagens plásticas fomentado pela comercialização de óleos lubrificantes automotivos no Brasil tem se tornado expressivo durante a última década motivado, principalmente, pelo aumento da frota automotiva que saltou de cerca de 45 milhões de veículos em 2006 para mais de 100 milhões em 2018 (IBGE, 2019). A embalagem pós-consumo, contendo resíduo oleoso, insere-se como um desafio ambiental persistente, especialmente, quanto a sua destinação final, uma vez que os materiais plásticos têm curtos ciclos de vida e longos tempos para degradação após seu descarte, contribuindo com o agravamento de problemas como impermeabilização dos solos, aumento do volume de lixões com proliferação de doenças e assoreamento dos rios e lagos. Nesse sentido, tornam-se importantes as ações sustentáveis para implementação da logística reversa que, segundo Martins (2014), tornou-se um instrumento baseado em técnicas inadequadas para descontaminação, armazenamento e transporte das embalagens.

Importantes compromissos internacionais ambientais foram norteadores significativos das políticas públicas brasileiras relativas ao tema em questão. A preocupação internacional com a geração de resíduos é antiga e acabou fomentando diversas discussões importantes em torno de princípios fundamentais ambientais, como da prevenção, precaução, do poluidor-pagador, do desenvolvimento sustentável e da razoabilidade e proporcionalidade, dentre outros. Nesse contexto, foi na Rio-92, realizada há quase três décadas, que o Brasil se colocou na posição de protagonista para o estabelecimento de relevantes diretrizes mundiais e, desde então, tem sido signatário de diversos tratados e convenções ambientais. 0 compromisso político sobre desenvolvimento sustentável foi reafirmado na Rio+20, em 2012, trazendo temas novos e emergentes, que no caso dos resíduos sólidos, revelou um antigo e grande dilema de relacionar a produção ao menor impacto ambiental.

A criação da Política Nacional de Resíduos Sólidos (PNRS), por meio da Lei Federal 12.305/2010, regulamentada pelo Decreto 7.404/2010, representa importante avanço da legislação ambiental brasileira, principalmente, no que diz respeito a logística reversa, instrumento de desenvolvimento econômico e social. Segundo Mendonça et al. (2017), a citada Lei inovou o ordenamento jurídico brasileiro, destacando a proibição de lixões, a atribuição de responsabilidade pela geração dos resíduos sólidos, a inclusão social dos catadores, a logística reversa, a responsabilidade compartilhada, previsão de planos de resíduos sólidos, responsabilidade quanto ao condicionamento do resíduo oriundo de coleta seletiva e os acordos setoriais.

Apesar disso, em quase dez anos da existência da PNRS, o caminho mais usualmente percorrido pelas embalagens pós-consumo de lubrificantes continua sendo idêntico ao do "lixo comum", ou seja, a deposição em aterros e lixões. Como consequência, atores ambientais de grande relevância na área de Resíduos Sólidos, as recicladoras adquirem sua matéria-prima contaminada por diversos outros materiais, o que praticamente inviabiliza economicamente seu negócio: as dificuldades em relação à obtenção e à segregação de insumo útil de boa qualidade e a falta de incentivo fiscal à reciclagem, estão entre os principais impeditivos para que a reciclagem mecânica de resíduos plásticos pós-consumo se torne um negócio rentável e para que, consequentemente, aconteça o crescimento desse mercado. Nesse contexto, Shi et al. (2012) apontaram que se espera um real valor útil para o resíduo, do ponto de vista do consumo, ao tratar a logística reversa como verdadeiro instrumento de desenvolvimento econômico e social, que deve ser cuidadosamente gerida para atingir a finalidade a que se destina.

Ao estudar o caso do programa "Jogue Limpo" do Sindicato Nacional das Empresas Distribuidoras de Combustíveis e de Lubrificantes (SINDICOM, atualmente denominado PLURAL), criado para viabilizar a logística reversa nesse importante segmento da indústria, pondera-se que o referido programa está baseado em técnicas inadequadas quanto às operações de drenagem, armazenamento temporário e transporte para destino final, além de ter abrangência limitada a menos de $4 \%$ do resíduo pós-consumo dessa natureza (MARTINS, 2014). Apesar de importante iniciativa, estratégias de marketing supervalorizaram o programa Jogue Limpo, criando uma falsa impressão de que essa cadeia produtiva cumpre plenamente seus deveres frente às disposições da Política Nacional de Resíduos Sólidos, conforme Lei $12.305 / 10$.

\section{OBJETIVOS}

O objetivo principal desse trabalho é avaliar o cenário atual da logística reversa de embalagens de lubrificantes automotivos no Brasil, seus avanços e entraves, especialmente frente as exigências da 
Política Nacional de Resíduos Sólidos (PNRS), estabelecida por meio da Lei 12.305/2010 e seu Decreto regulamentador 7.404/2010.

\section{METODOLOGIA}

A metodologia se baseou em revisão da literatura técnico-científica sobre logística reversa, tendo como foco especificamente as embalagens de lubrificantes automotivos pós-consumo, considerando os dispositivos legais aplicáveis, os acordos setoriais estabelecidos e as práticas vigentes para coleta e destinação. A investigação assumiu uma abordagem geral descritiva e qualitativa, incluindo o importante estudo realizado por Martins (2014) que comprova que o único programa de logística reversa desse tipo de resíduo (Jogue Limpo) apresenta diversos problemas operacionais e logísticos, que impactam diretamente a viabilidade econômica-ambiental do sistema.

\section{RESULTADOS}

Apesar da recente retração do mercado de lubrificantes registrada em 2016, reflexo da performance da atividade econômica do país e recuo do setor industrial, a frota automotiva continua em crescimento e o setor de lubrificantes automotivos ainda lidera as vendas em relação aos demais produtos dessa linha (IBGE, 2019; SINDICOM, 2017).

Segundo a Agência Nacional do Petróleo - ANP (2017), dos 41.829 postos revendedores de combustíveis e lubrificantes do país, $41 \%$ são de bandeira branca e mais de $40 \%$ desse total se concentram na região Sudeste. Essa região continua responsável por, pelo menos, metade do consumo nacional de lubrificantes e é onde, geralmente, a retração das vendas tem menor impacto com a redução da atividade econômica. Portanto, a região Sudeste é naturalmente responsável por metade da demanda de embalagens de óleos lubrificantes do país (SINDICOM, 2017). Em 2018 a região possui a frota de aproximadamente 49 milhões de veículos, sendo São Paulo com mais de 29 milhões, seguido por Minas Gerais 11,1 milhões, Rio de Janeiro 6,7 milhões e Espírito Santo com 1,9 milhão de veículos. Os automóveis somam quase 29,9 milhões de unidades enquanto as motocicletas totalizam 8,5 milhões de unidades e caminhões 1,2 milhão (IBGE, 2019).

O importante marco da Política Nacional de Resíduos Sólidos (PNRS) em 2010 foi de buscar igualar o Brasil aos demais países desenvolvidos e, desde então, procura-se implementar seus objetivos e princípios de forma a incluir todos os responsáveis pela geração do resíduo e o poder público. Ao comparar o que preconiza o Decreto 7404/2010, no contexto das embalagens de lubrificantes pós-consumo com as práticas diárias dos pontos de geração de embalagens de lubrificantes, pondera-se que alguns compromissos não têm sido cumpridos em sua totalidade. É notório que ao longo dos quase dez anos da Política, as questões de infraestrutura, inexistência de uma sistemática definida para coleta e destinação das embalagens continuam representando uma das principais barreiras para efetiva implementação da logística reversa (MENDONÇA et al., 2017).

No que se refere aos princípios da PNRS (BRASIL, 2010a), verifica-se a pouca visão sistêmica na gestão em consonância com a cooperação entre os diversos atores envolvidos no contexto da responsabilidade compartilhada. Nesse aspecto, é relevante observar dois pontos: o primeiro é em relação a real cooperação do setor público na implementação da logística reversa das embalagens. Propor e oficializar as políticas públicas por meio de normativas jurídicas não garante o cumprimento delas, sendo necessário aumentar os mecanismos de controle fiscalizatório. Dessa forma, a criação de uma normativa fraca, que é o caso do Brasil, obriga maior controle para o seu cumprimento. Um exemplo disso é que até hoje o Brasil não conseguiu melhorar sua infraestrutura para implementar a logística reversa, principalmente em relação a coleta seletiva. O segundo ponto é a real cooperação do setor privado na implementação da logística reversa. Não basta estabelecer programas de "marketing", é preciso que, de fato, haja real comprometimento do setor produtivo com a implementação da logística reversa, entendendo que esse é o principal responsável pelo resíduo.

Embora sejam conhecidas as últimas ações do Programa Jogue Limpo para aumentar a capilaridade do sistema de logística reversa, muito ainda é preciso fazer. A atual propaganda do Programa, conforme Figura 1, reflete mais um esforço de marketing do que um compromisso verdadeiramente assumido entre todos os envolvidos na cadeia produtiva dos lubrificantes automotivos. 0 cenário atual brasileiro, no contexto da gestão ambiental, apresenta reiterados entraves, principalmente, de natureza operacional, logística e econômica. 
Figura 1: Atual propaganda do Programa Jogue Limpo.

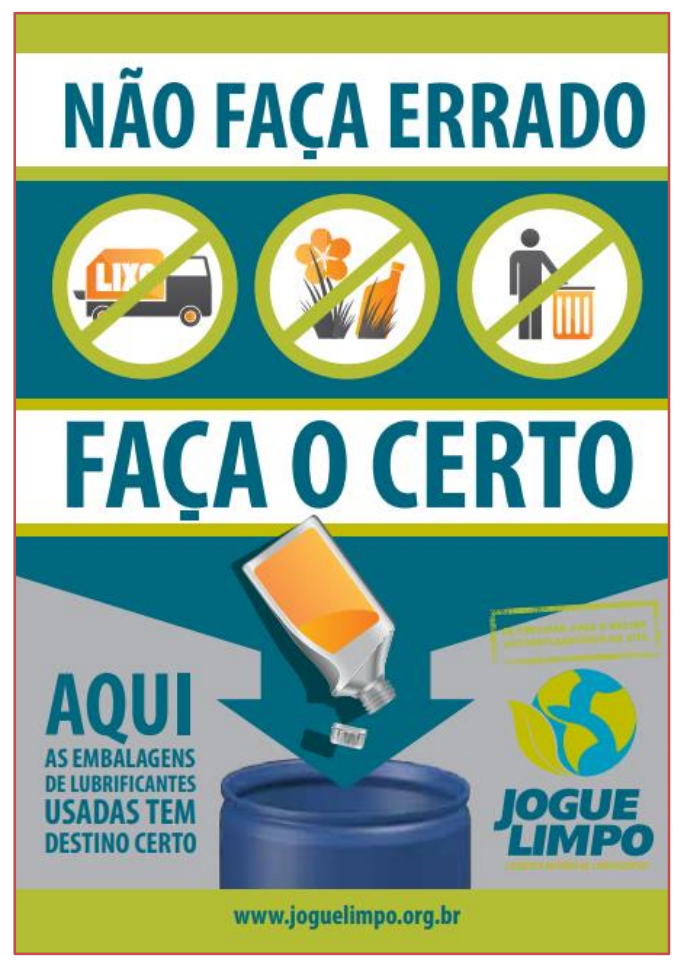

Fonte: Jogue Limpo (2018).

Além disso, verifica-se a baixa ecoeficiência da Política no sentido da falta de estímulos de preços mais competitivos ao desenvolvimento de mercado dos recicláveis. Clini et al. (2008) argumentam que qualquer proteção ambiental deve ser compatível com o crescimento econômico e isso só é percebido através da melhoria contínua da ecoeficiência. A ecoeficiência, princípio esse que nos remete a busca para alcançar melhores resultados e melhores rendimentos das ações ambientais planejadas, pode ser relacionada com o objetivo da PNRS quanto à gestão integrada. A busca de soluções para os resíduos sólidos sob a premissa do desenvolvimento sustentável é o referencial da gestão integrada, sendo assim, o conjunto de ações deve ser partilhado entre os diferentes responsáveis, sejam públicos ou privados, com a qualidade necessária para atingir ao princípio da ecoeficiência. A qualidade se torna um ingrediente-chave para o sucesso em atender as necessidades e expectativas, isso inclui assegurar a qualidade consistente na gestão da logística reversa (NIKOLAIDIS, 2013).

Ainda sobre as embalagens de óleo lubrificante, inseridas nas diretrizes do gerenciamento de embalagens do Programa Jogue Limpo, pode-se afirmar que o cenário atual é o mesmo de quase dez anos atrás. De acordo com Martins (2014) no documento norteador "Manual de Coleta e Destinação de Embalagens Plásticas de Óleo Lubrificante" continuam evidentes as incongruências com padrões de execução propostos, principalmente, em relação a separação e armazenagem nos pontos de coleta .A disposição das embalagens plásticas sem qualquer critério demonstra a necessidade de ações significativas capazes de minimizar as diferentes formas de poluição e os impactos negativos associados. A Figura 2 representa uma prática diária em um dos pontos de serviço visitados, onde informa, inclusive, nunca ter recebido a visita do Coletador Autorizado. Esse é o caso do Posto BR "Rias Baixas", localizado na Avenida Presidente Vargas - RJ, cuja destinação dos frascos de óleo lubrificantes pós-venda é o lixo comum. 
Figura 2: Armazenamento temporário inadequado das embalagens.

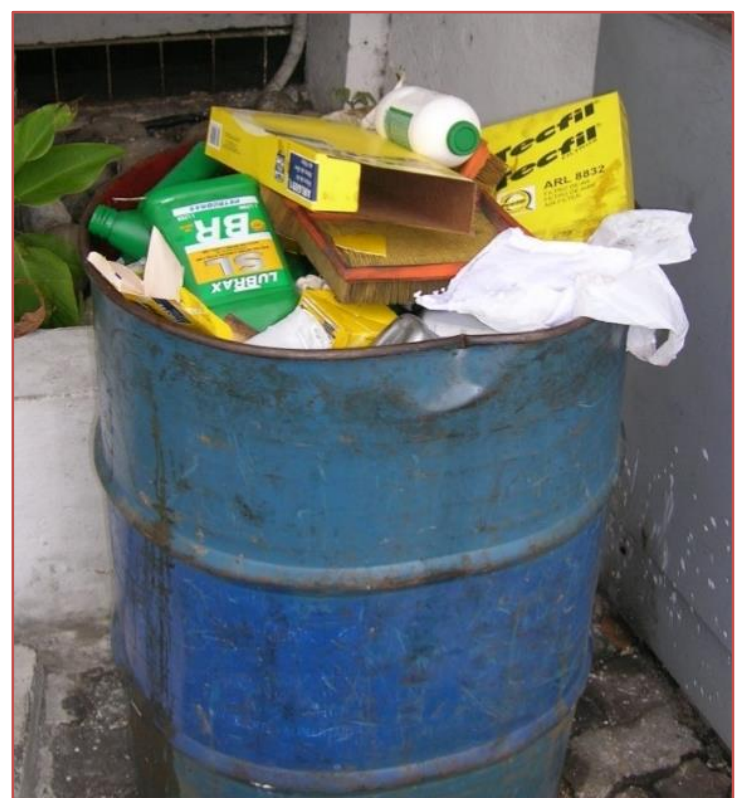

Fonte: Autor (2019).

Há, também, práticas de armazenamento inadequado das embalagens, como evidenciado na Figura 3 (Posto BR Bracarense, localizado na Praça da Bandeira - RJ). Em muitos casos há escorrimento do óleo diretamente para o solo com galeria pluvial desprotegida e as embalagens usadas são armazenadas destampadas. A estocagem é geralmente realizada em sacos de lixo, suportados ou não por outras estruturas como bombonas ou tambores. Alguns declaram destinar as embalagens para o lixo comum, desconsiderando o fato de se tratar de resíduo perigoso. Além disso, os pontos não possuíam o documento comprobatório da destinação ao programa de logística reversa.

Figura 3: Armazenamento temporário inadequado das embalagens.

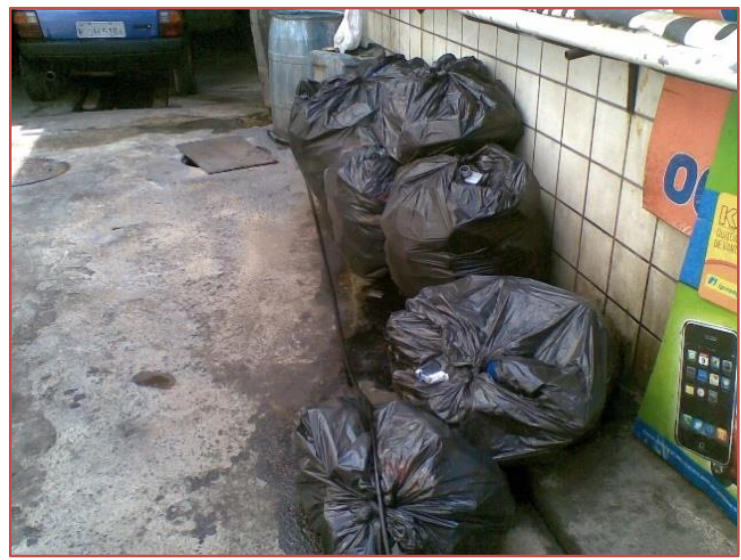

Fonte: Autor (2019).

A armazenagem das embalagens e a coleta do óleo também representam relevantes etapas dessa sistemática que impactam a efetividade do Programa. A ineficácia das metodologias utilizadas para tratamento e destinação são constatadas por meio das deficiências significativas quanto às sistemáticas para separação da fração oleosa e armazenamento temporário com consequências diretas para o transporte seguro e a viabilidade da reciclagem (MARTINS et al, 2013). Em muitos casos, as embalagens são destinadas sem qualquer drenagem prévia do óleo. Sabe-se que as embalagens de PEAD (polietileno de alta densidade) pós-consumo com óleo lubrificante remanescente amplificam a problemática da periculosidade do resíduo porque, teoricamente, dificulta a reciclagem do material e onera o processo. 0 
plástico com material oleoso confere ao resíduo a classificação “Classe I - Perigoso" dificultando também a metodologia de transporte e destinação (MARTINS, 2014).

A Figura 4 apresenta situação real identificada em um dos postos de serviço abrangidos pelas rotas do Programa Jogue Limpo. A imagem mostra uma pingadeira comercial frequentemente utilizada para remoção do óleo remanescente das embalagens e evidencia a inadequação desse equipamento para a função, tendo em vista a falta de organização e posicionamento as embalagens na ocasião do escoamento.

Figura 4: Escoamento inadequado do óleo lubrificante.

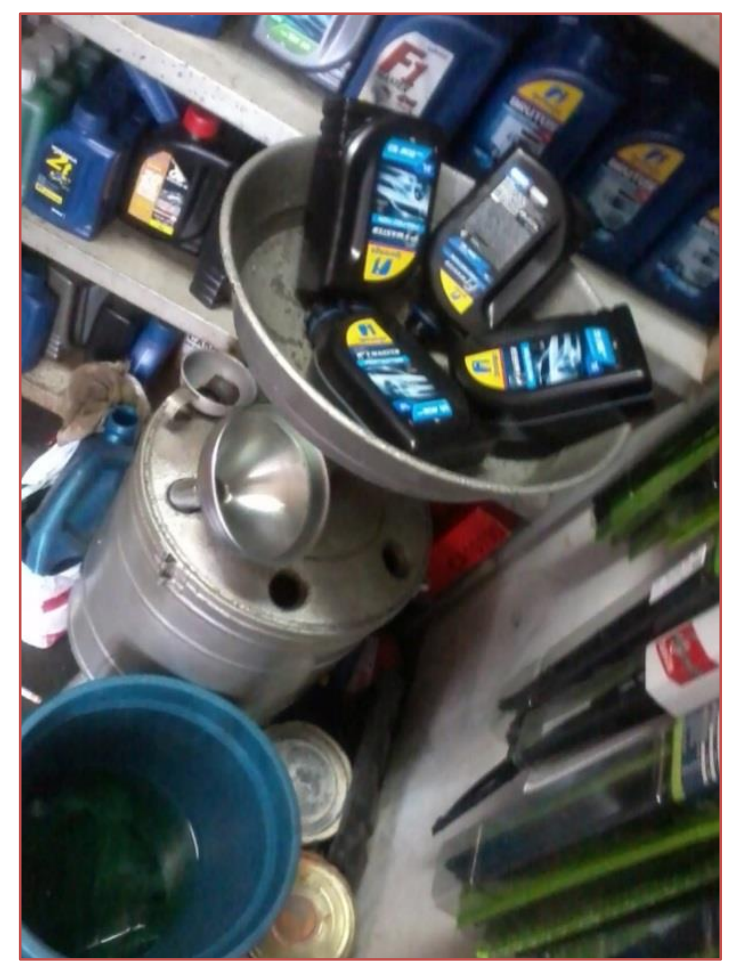

Fonte: Autor (2019).

Sabe-se que a limpeza das embalagens interfere no processo de forma significativa, onde o teor de óleo remanescente tem total impacto nas operações da recicladora. 0 excesso de óleo causa deformação das peças extrusadas ou injetadas, além de fazer com que os artefatos produzidos apresentem intenso odor de óleo queimado, restringindo as aplicações do material reciclado e reduzindo seu valor de venda (MARTINS, 2014).

Nesse contexto, a adoção de estratégias de otimização da drenagem gravitacional do resíduo oleoso das embalagens pós-consumo representa alternativa para viabilização da reciclagem mecânica direta desse tipo de termoplástico, tendo em vista que os altos custos de descontaminação dos frascos pelos métodos tradicionais têm se mostrado a mais importante barreira das recicladoras que se dispõe a reprocessar embalagens de PEAD por reciclagem mecânica. A reciclagem direta é mais viável economicamente, excluindo gastos com etapas como lavagem e secagem do resíduo pós-consumo, além da redução dos custos como tratamento dos efluentes desses processos.

Considerando o princípio da ecoeficiência, fica evidente que as práticas reais estabelecidas nesses postos não atendem esse princípio da Lei 12.305/10. 0 armazenamento temporário das embalagens e o processo de limpeza das mesmas não estão articuladas e integradas tecnicamente ao Programa. Essas práticas oneram o processo de descontaminação das embalagens e contribuem para inviabilizar economicamente a reciclagem. O total desconhecimento sobre a sistemática adotada para o escoamento do óleo das embalagens pós-consumo e os sobre documentos formais necessários para recolhimento do resíduo evidenciam mais uma vez a ineficiência do Programa. Destaca-se, inclusive, a falta de treinamento e conscientização dos funcionários que também fazem parte das ações para uma efetiva ecoeficiência e gestão integrada citada na PNRS. 
O sistema de transporte das embalagens pós-consumo também apresenta entraves associados. Os veículos com rota definida que saem dos pontos de geração precisam, geralmente, interromper a coleta e retornar toda vez que o volume do baú é preenchido, mesmo considerando que o baú suportaria carga muito superior. Esse entrave logístico poderia ser solucionado com a fragmentação das embalagens nos pontos de revenda. Nesse sentido, Martins (2014) sugere, dentre outras melhorias, que as embalagens sejam trituradas antes do transporte para aumento da densidade aparente do material. Essa alternativa pode trazer diversos benefícios, além do logístico, porque representa economia no quantitativo das viagens realizadas e redução do consumo de combustível do próprio veículo. Cabe ressaltar que para essa ação se faz necessária a adoção de práticas mais eficientes para a retirada do óleo das embalagens pós consumo, para reduzir a contaminação das mesmas (MARTINS et al, 2013).

Importantes ações poderiam incentivar práticas articuladas e integradas ao sistema de logística reversa. Apesar de não haver normativa jurídica federal brasileira específica que estabeleça multas e prazos aos participantes da cadeia produtiva das embalagens, sugere-se que seja realizado um plano para gerenciamento de embalagens de óleo lubrificante pós-consumo, alvo de Legislação Federal específica, com maiores estímulos à realização de ações de fiscalização e controle.

O Decreto Federal 7.404/10, que regulamenta a PNRS, prevê um Comitê Orientador para avaliar e verificar a necessidade de revisão dos acordos setoriais e que atue de forma a aferir seus resultados (SINIR, 2018; BRASIL, 2010b). Nesse sentido, considera-se relevante que esse Comitê atue, cada vez mais, na orientação da implementação de um efetivo sistema de logística reversa no país de forma a atender o interesse público e incorporar os benefícios da reciclagem à toda sociedade. 0 acordo setorial, que é de natureza contratual, por ser de interesse público que atinge a coletividade, deveria contemplar sanções e critérios específicos para o efetivo cumprimento das ações planejadas.

Ressalta-se a importância de as ações de fiscalização serem vinculadas aos conceitos de educação ambiental e que atendam ao princípio da razoabilidade e proporcionalidade também presentes na PNRS, que objetiva evitar os exageros quanto a aplicabilidade da lei. Assim, acredita-se que seja importante uma parceria de apoio fiscalizatório dos Órgãos Ambientais Estaduais ao Comitê Orientador na avaliação da efetiva implantação dos acordos setoriais.

É relevante também a implantação de políticas públicas de incentivo à reciclagem, de forma que inclua a redução da tributação dos resíduos plásticos pós-consumo, a criação de taxas para embalagens não recicláveis, a obrigatoriedade de uso exclusivo de material reciclado em alguns setores produtivos, o fornecimento de subsídios para substituição da resina virgem pela reciclada e, até mesmo, a determinação para que as compras do governo e de seus fornecedores priorizem aquisição de recicláveis (MARTINS, 2014).

\section{CONCLUSÕES}

Não há dúvida de que a criação da PNRS representa importante avanço da legislação ambiental brasileira, entretanto não há evidências de que diversos dos princípios nela contidos sejam aplicados, de forma efetiva, mesmo após quase dez anos de sua publicação. No que tem relação com a logística reversa de embalagens de lubrificantes automotivos pós-consumo (artigo 33, Lei 12.305/10), pode-se concluir pelo presente estudo que as obrigações legais preconizadas pela PNRS não têm sido cumpridas pelos diversos atores dessa cadeia produtiva. A pesquisa ainda conseguiu determinar que diversas são as razões para que essa situação esteja estabelecida, dentre as quais, a falta de definições legais objetivas de responsabilidades, prazos e sanções a serem aplicadas aos infratores.

É evidente que a ineficácia dos processos tradicionais de descontaminação das embalagens pós-consumo, assim como dos processos de armazenamento temporário e transporte dos resíduos, a falta de incentivo às recicladoras e de fiscalização dos órgãos públicos de controle ambiental têm sido problemas reiterados ao longo desses anos de PNRS. Além disso, os custos do processo de descontaminação das embalagens praticamente inviabilizam economicamente o processo de reciclagem. Contudo, a melhoria do processo de escoamento do óleo das embalagens significa a possibilidade de fazer reciclagem mecânica direta, o que não seria possível com o processo de escoamento atualmente empregado, uma vez que o teor de resíduo de abastecimento nas embalagens ainda é alto e fariam com que problemas operacionais e na qualidade do produto final acontecessem, como é o caso de peças defeituosas e com odor de óleo queimado. 
É preciso avaliar de maneira ampla a questão dos resíduos plásticos no Brasil e propor regulamentação que considere concomitantemente conceitos básicos de educação ambiental, obrigações, responsabilidades às empresas participantes da cadeia produtiva, autorizando os organismos de controle e fiscalização na realização de vistorias e autuações. Para isso, é relevante a contínua atuação do Comitê Orientador e dos Órgãos de fiscalização.

\section{REFERÊNCIAS}

[1] ANP. Agência Nacional do Petróleo, Gás Natural e Biocombustíveis. Anuário Estatístico 2017. Disponível em: <http://www.anp.gov.br/p ublicacoes/anuario-estatistico/3819-anuario-estatistico-2017>. Acesso: 04 de setembro de 2019.

[2] BRASIL. Lei Federal 12.305, 02 de agosto de 2010. Institui a política nacional de resíduos sólidos, altera a Lei Federal 9.605, de 12 de fevereiro de 1998 e dá outras providências. 2010a. Disponível em: <http://www.planalto.gov.br/ccivil_03/_ato2007-2010/2010/lei/l12305.htm>. Acesso: 23 de junho de 2019.

[3] BRASIL. Decreto Federal 7.404, 23 de dezembro de 2010. Regulamenta a Lei no 12.305, cria o comitê interministerial da política nacional de resíduos sólidos e o comitê orientador para a implantação dos sistemas de logística reversa, e dá outras providências. 2010b. Disponível em: <http://www.planalto.gov.br/ccivil_03/_ato20072010/2010/Decreto/D7404.htm>. Acesso: 23 de junho de 2019.

[4] CLINI, C.; MUSU, I.; GULLINO, M.L. Sustainable Development and Environmental Management - Experiences and Case Studies. Springer, 2008.

[5] IBGE. Instituto Brasileiro de Geografia e Estatística. Frota de veículos 2019. Disponível em:<https://cidades.ibge.gov.br/brasil/sp/pesquisa/22/28120?localidade1=33\&tipo=grafico\&localidade2=0>. Acesso em: 04 de outubro de 2019.

[6] MARTINS, H. M. A Destinação Final das Embalagens de Óleo Lubrificante: O Caso do Programa “Jogue Limpo". Dissertação de Mestrado. Faculdade de Engenharia, Universidade do Estado do Rio de Janeiro, Rio de Janeiro, 2005.

[7] MARTINS, H. M.; CAMPOS, J. C.; GUIMARAES, M. J. O. C; BASSANI, G. S. Avaliação do Cenário Atual e Proposição de Melhorias no Processo de Tratamento e Disposição de Embalagens de Lubrificantes. In: XV Encontro Internacional sobre Gestão Empresarial e Meio Ambiente - ENGEMA, 2013. São Paulo - SP.

[8] MARTINS, H. M. Análise do Cenário Atual e Desenvolvimento de Metodologia para Otimização da Logística Reversa de Embalagens de Lubrificantes Automotivos Pós-Consumo. Tese de Doutorado. Escola de Química, Universidade Federal do Rio de Janeiro, Rio de Janeiro, 2014.

[9] MENDONÇA, J.C.A.; VASCONCELOS, P.E.A.; NOBRE, L.B.O.; CASAROTTO, E.L. Logística Reversa no Brasil: Um estudo sobre o mecanismo ambiental, a responsabilidade social corporativa e as legislações pertinentes. Revista Capital Científico. ISSN 2177-4153 - Vol. 15 n.2 - Abril/Junho, 2017.

[10] NIKOLAIDIS, Y. Quality Management in Reverse Logistics. A Broad Look on Quality Issues and Their Interaction with Closed-Loop Supply Chains. University of Macedonia. Springer-Verlag London, 2013. DOI 10.1007/978-1-4471-4537-0.

[11] SHI, X.; Li, L.X.; Yang, L.; Li, Z.; Choi, J.Y. Information flow in reverse logistics: an industrial information integration study. Inf Technol Manag 13, p. 217-232, 2012.

[12] SINDICOM. Sindicato Nacional das Empresas Distribuidoras de Combustíveis e de Lubrificantes. Combustíveis, Lubrificantes e Lojas de Conveniência 2017 - Anuário 2017. Disponível em: <https://somosplural.com.br/wp-content/uploads/2018/03/anuario_sindicom_2017.pdf>. Acesso: 30 de agosto de 2019.

[13] SINIR. Sistema Nacional de Informações sobre a Gestão dos Resíduos Sólidos. Relatório Anual de Desempenho 2017. Programa $\quad$ Jogue Limpo. Disponível em:<https://sinir.gov.br/images/sinir/LOGISTICA_REVERSA/RELATORIOS_ANUAIS/EMBALAGENS_PLASTICAS/201 7/Relatorio_anual_desempenho_\%202017.pdf>. Acesso: 01 de setembro de 2019.

[14] SINIR. Sistema Nacional de Informações sobre a Gestão dos Resíduos Sólidos. Comitê Orientador, 2018. Disponível em:<https://sinir.gov.br/logistica-reversa>. Acesso em: 05 de setembro de 2019. 


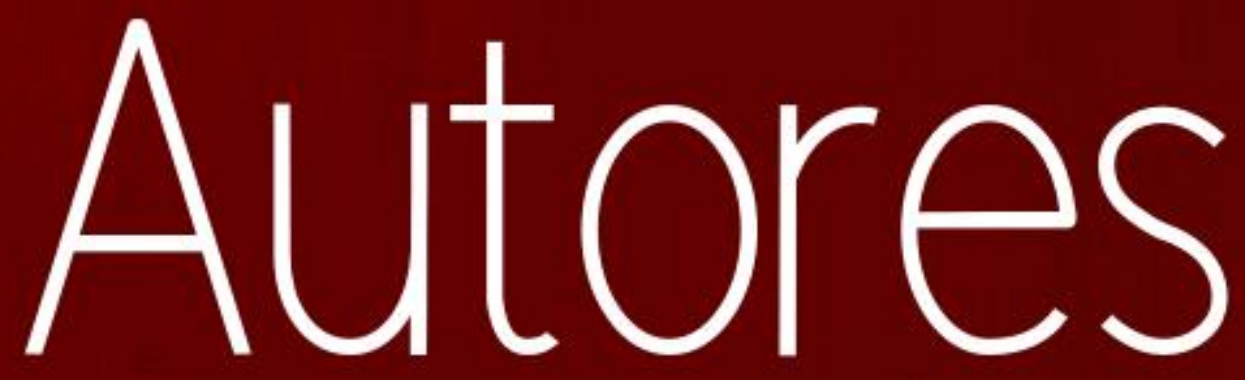




\section{ADENILSON EVANGELISTA BOTELHO}

Mestrando do Mestrado Profissional em Rede Nacional em Gestão e Regulação de Recursos Hídricos - ProfÁgua, com graduação em Engenharia Agrícola e Ambiental pela Universidade Federal de Viçosa - UFV e pós-graduação em Gestão Bancária e Negócios pela Escola Superior Aberta do Brasil - ESAB. Possui experiência em mecanização agrícola com ênfase em visão artificial e geoprocessamento. Atualmente trabalha na empresa Banco do Brasil S.A.

\section{ADRIANA ANTUNES LOPES}

Docente do IFSP - campus São Carlos. possui graduação em Arquitetura e Urbanismo pela Universidade Estadual Paulista "Julio de Mesquita Filho", UNESP - Bauru (1998), mestrado (2003) e doutorado (2007) em Ciências da Engenharia Ambiental pela Escola de Engenharia de São Carlos, Universidade de São Paulo. Tem experiência na área de Saneamento Ambiental, com ênfase em Resíduos Sólidos, atuando principalmente nos seguintes temas: gestão de resíduos sólidos, monitoramento de aterros sanitários, impactos ambientais e planejamento ambiental.

\section{ALLAN LUÍS AUGUSTO REDES DE OLIVEIRA}

Mestre em Ciências Mecânicas pela Universidade de Brasília - UnB.

\section{ALYSON RODRIGUES AMARAL}

Graduação em Engenharia Ambiental pelo Instituto Federal Goiano (IF Goiano) Campus Rio Verde. Analista ambiental. Experiência como profissional autônomo na área de consultoria ambiental, auxiliando empreendedores na elaboração de projetos ambientais e no acompanhamento de processos de licenciamento ambiental junto aos órgãos ambientais; Experiência como analista ambiental do Departamento de Licenciamento Ambiental da Agência Municipal do Meio Ambiente de Itumbiara (AMMAI), trabalhando com a análise de processos de licenciamento ambiental de empreendimentos rurais, comerciais e industriais.

\section{ANA KAROLINE DOMICIANO}

Gestora Financeira pela Faculdades do Centro do Paraná, 2013. Técnica em Agroecologia e Agropecuária pelo Instituto Federal de Educação, Ciências e Tecnologia do Paraná, 2014. PósGraduada em Segurança Pública pela Faculdade São Braz, 2019. Graduada em Engenharia Ambiental pela Universidade Estadual do Centro-Oeste do Paraná, 2020. Integrante voluntária de projetos de pesquisa e extensão nas áreas de geoprocessamento e sensibilização ambiental. Bolsista Fundação Araucária em projeto de pesquisa na área de gestão de resíduos urbanos.

\section{ANA LÍDIA PICANÇO MOREIRA}

Técnica de Segurança do Trabalho pelo GST-Evolução (2012), Graduanda em Engenharia de Minas pela Universidade Federal do Oeste do Pará-UFOPA, desenvolveu atividades relacionadas à área de segurança do trabalho. Interessa-se por trabalhos voltados à pesquisa mineral.

\section{ARMANDO DE AZEVEDO CALDEIRA PIRES}

Engenheiro Químico e Mestre em Engenharia Química pela UFRJ, e Doutor em Engenharia Mecânica pela Universidade Técnica de Lisboa em 1995. Atualmente é Professor Adjunto da Universidade de Brasília, Pesquisador Visitante do Instituto Superior Técnico e membro do Comitê Gestor do Programa Brasileiro de Avaliação do Ciclo de Vida ? Conmetro/MDIC. Publicou mais de 34 artigos em periódicos especializados e de 120 trabalhos em anais de eventos. Possui 1 livro e 8 capítulos de livros publicados. Tem atuado como consultor para diferentes órgãos do governo e da iniciativa privada. Participa continuamente em eventos no exterior e no Brasil. Orientou mais de 25 dissertações de mestrado, além de 10 teses de doutorado, além de ter orientado diversos trabalhos de iniciação científica e de conclusão de curso nas áreas de Engenharia Mecânica, Engenharia de Transportes e Engenharia de Produção. Entre 2002 e 2014 coordenou, ou participou, em mais de 
25 projetos de pesquisa multi-institucionais. Atualmente participa de 7 projetos de pesquisa, sendo que coordena 2 destes, e orienta 2 dissertações de mestrado e 3 teses de doutorado. Atua na área de Engenharia Mecânica, com ênfase em Combustão, e na área de Engenharia de Produção, com enfase em Gestão de Produtos e Ecologia Industrial. Em suas atividades profissionais interagiu com mais de 70 colaboradores em co-autorias de trabalhos científicos. Em seu currículo Lattes os termos mais freqüentes na contextualização da produção científica, tecnológica e artístico-cultural são: Environmental Assessment, Combustão, Life Cycle Assessment, Métodos Experimentais, Industrial Ecology e Gestão de C\&T.

\section{DEMERSON FERNANDES DA SILVA}

Possui graduação em Engenharia Ambiental e Sanitária pela Faculdade Pitágoras (2016), graduação em Gestão Ambiental pela Fundação Universidade de Itaúna (2007), Especialização em Segurança do Trabalho pela Faculdade Pitágoras (2018) em curso de Mestrado na modalidade de disciplinas Isoladas do Mestrado Profissional em Sustentabilidade e Tecnologia Ambiental (MPSTA) do IFMG Campus Bambuí e técnico em Química Instituto CECON (2009). Atualmente é analista de meio ambiente - Ferrovia Centro - Atlântica S/A. Tem experiência na área de Engenharia Ambiental, Gerenciamento de resíduos sólidos, Gestão de Recursos Hídricos, Não Conformidades Ambientais, Educação Ambiental, Requisitos Legais, Gestão de Contratos.

\section{DIRCEU JOSÉ DOS SANTOS JÚNIOR}

Graduação em Engenharia Civil, pós graduando em Engenharia de Segurança, cursando Mestrado Profissional em Sustentabilidade e Tecnologia Ambiental pelo IFMG, (Instituto Federal de Minas Gerais), atualmente Analista Operacional na Ferrovia Centro Atlântica, na gestão e execução de obras e manutenções civis ao longo do corredor Centro Leste.

\section{ELDEN DE ALBUQUERQUE MARIALVA}

Possui graduação em Engenharia Mecânica pela Universidade Federal do Pará (2006) e mestrado em Engenharia Mecânica pela Universidade Federal do Pará (2010). Professor assistente na universidade Federal do Oeste do Pará de 2017 até atualmente, foi engenheiro mecânico da Fundação de Amparo e Desenvolvimento da Pesquisa do Pará de maio de 2008 a maio de 2012. Tem experiência na área de Engenharia Mecânica, com ênfase em Engenharia Térmica, atuando principalmente nos seguintes temas: geração de energia, eficiência, biomassa, turbina, ciclo a vapor, área de manutenção e analise ambiental.

\section{ELIANE MARIA VIEIRA}

Possui graduação em Engenharia de Agrimensura pela Universidade Federal de Viçosa (2003), mestrado em Engenharia Civil pela Universidade Estadual do Norte Fluminense Darcy Ribeiro (2005) e doutorado em Engenharia Civil pela Universidade Federal de Viçosa (2009). Atualmente é professora na Universidade Federal de Itajubá - Campus Itabira, no curso de Engenharia Ambiental. Tem experiência na área de Geociências, atuando principalmente nos seguintes temas: geoprocessamento, sensoriamento remoto, topografia, zoneamento, caracterização do meio biofísico, qualidade da água. Coordenadora adjunta pela UNIFEI do Mestrado Profissional em Gestão de Recursos Hídricos (ProfÁgua) .

\section{ELINALDO ALVES}

Possui graduação em ADMINISTRAÇão pela Universidade Federal do Amazonas (2010), é especialista em GESTÃO PÚBLICA pela Universidade Estadual do Amazonas (2013), possui MBA em Gestão Financeira Controladoria e Auditoria, pela Fundação Getúlio Vargas - FGV (2019), exerce função de Administrador no setor Público e exerce função de conselheiro no Instituto Juruti Sustentável-IJUS. 


\section{EULLER DA CONCEIÇÃO TAVARES}

Graduando do Curso de engenharia de Minas, pela Universidade Federal do Oeste do Pará UFOPA, Juruti/PA. Interessa-se por trabalhos de pesquisa e beneficiamento mineral.

\section{FELLIPE DALYSON GADELHA SILVA}

É graduando em Engenharia Civil pela Universidade Federal de Campina Grande. Foi pesquisador voluntário pelo Programa Institucional de Voluntários de Iniciação Científica. Atualmente é estagiário na empresa Massai Construções e Incorporações.

\section{FERNANDO DE FARIAS FERNANDES}

Possui graduação em Engenharia Civil pela Universidade Federal do Amazonas (1988). Mestre em Engenharia de Materiais pela ULBRA -Canoas-RS. É professor da Escola Superior de Tecnologia da Universidade do Estado do Amazonas . Professor do Centro Universitário Luterano de Manaus. Tem experiência na área de Engenharia Civil, com ênfase em Materiais e Construção Civil, atuando principalmente nos seguintes temas: resíduo, concreto, carbureto, desperdício e pavimentação.

\section{FLÁVIA MOURA DE MORAES}

Possui graduação em Química Industrial pela Universidade Católica de Pernambuco (1990). Atualmente é gerente de responsabilidade socioambiental - ASA indústria ltda, gerente de qualidade e desenvolvimento. - ASA indústria ltda, professor de pós-graduação gestão produção da Faculdade Frassinetti d Recife e professor convidado da Universidade de Pernambuco. Cursando um Mestrado Profissional na linha de Sustentabilidade na Fundação Getúlio Vargas SP. Tem experiência na área de Engenharia Química, com ênfase em Engenharia Química, atuando principalmente no seguinte tema: sustentabilidade.

\section{FREDERICO CORDEIRO MARTINS}

Doutorando em Sistemas de Informação e Gestão do Conhecimento pela Universidade FUMEC. Possui graduação em Direito pelo Centro Universitário de Sete Lagoas (2003) e mestrado em Turismo e Meio Ambiente pelo Centro Universitário UNA (2011). Atualmente atua como Advogado. Tem experiência na área de Direito, com ênfase em Direito Ambiental, Direito do consumidor, Direito Penal e Processual Penal. Possui experiência em docência, já tendo lecionado no Centro Universitário UNA de 2006 a 2009, nas disciplinas de Direito do Consumidor, Direito Tributário, Direito Ambiental e Ética e em orientação de alunos e acompanhamento de audiências no núcleo de prática jurídica do UNI-BH de 2004 a 2005. Lecionou no Centro Universitário - UNIBH, de 2012 a 2015, nas disciplinas de Direito e Legislação em Engenharia, Certificação Ambiental, Fundamentos de Direito e Direito Empresarial. Lecionou na UEMG, em 2017 e 2018. Exerceu, no ano de 2018 a função de Coordenador de Pesquisa e Extensão na UEMG - Universidade do Estado de Minas Gerais, Unidade Cláudio. É editor, avaliador e revisor do periódico Ciências Gerenciais em Foco da UEMG - Universidade do Estado de Minas Gerais, Unidade Cláudio.

\section{GASPAR SEBASTIÃO FRANCISCO CRISTÓVÃO}

Licenciado em Geografia pelo Instituto Superior Pedagógico de Pinar del Rio Cuba em 2006. Docente da Escola Superior Pedagógica do Bié, da Universidade José Eduardo Dos Santos Angola, cursos de Ensino da Biologia, da Geografia e da Química. Leciono as disciplinas: educação ambiental, ecologia, pedagogia e metodologia de ensino da geografia. Atualmente sou aluno de mestrado do Programa de Pós Graduação em Ciências Ambientais na Unesp, Campus de Sorocaba. 


\section{GERALDO RAMOS MADEIRA}

Mestrando profissional em Gestão e Regulação de Recursos Hídricos pelo ProfÁgua UNIFEI Campus Itabira/MG. Licenciando em Pedagogia pela FAVED. Graduado em Administração de Empresas pela Faculdade FUNCESI. Especialista em Educação Ambiental pela Faculdade SENAC MG e pós-graduado em Gestão Ambiental pela FINOM MG. Já atuou como professor e coordenador do curso técnico em Meio Ambiente e Gestão Ambiental do Centro Educacional Santa Edwiges (CESE) e Escola CERP. Profissional com 32 anos de experiência na área ambiental da empresa Vale S/A. A atuação foi com foco direto no relacionamento com as comunidades, no desenvolvimento de programa de Educação Ambiental e no Sistema de Gestão Ambiental. Possui experiência de mais de 03 anos na administração pública atuando como Secretário Adjunto de Agricultura e Abastecimento, Gerente de Comunicação, Gerente da Usina de Triagem de Resíduos Sólidos e Gerente de Serviços de Limpeza Urbana. Atuou como membro e coordenador do Grupo de Voluntários da empresa Vale S/A.

\section{GERSON ARAUJO DE MEDEIROS}

Graduado em Engenharia Agrícola, Mestre e Doutor em Engenharia de Água e Solo pela Universidade Estadual de Campinas (UNICAMP). Em 2015 e 2018 realizou períodos de intercâmbio respectivamente na Universidade de Alberta (UofA), no Canadá, e na Universitat Autônoma de Barcelona (UAB), na Espanha. Desde 2011 é professor na Universidade Estadual Paulista (UNESP), Campus de Sorocaba, no curso de graduação em Engenharia Ambiental e no Programa de Pós Graduação em Ciências Ambientais. Nesses cursos tem atuado na área de Gestão Ambiental, orientando pesquisas sobre gestão de recursos naturais e antropizados.

\section{GIOVANA RANTHUM}

Graduanda em Engenharia Ambiental pela Universidade Estadual do Centro-Oeste do Paraná. Irati | 2015-2019. Auditora Interna em Gestão Ambiental pela Universidade Tecnológica Federal do Paraná. Ponta Grossa | 2017. Auditora interna em Saúde e Segurança no trabalho pela Universidade Tecnológica Federal do Paraná. Ponta Grossa | 2017. Estagiária no Instituto Ambiental do Paraná - Regional de Ponta Grossa. Outubro de 2019 | Dezembro de 2019. Integrante voluntária de projetos de pesquisa nas áreas de toxicologia ambiental, hidrologia e gestão de resíduos sólidos.

\section{GIOVANA RANTHUM VIECHNEISKI}

Auditora Interna em Gestão Ambiental pela Universidade Tecnológica Federal do Paraná, 2017. Auditora interna em Saúde e Segurança no trabalho pela Universidade Tecnológica Federal do Paraná, 2017. Estagiária no Instituto Ambiental do Paraná - Regional de Ponta Grossa, 2019. Graduada em Engenharia Ambiental pela Universidade Estadual do Centro-Oeste do Paraná, 2020. Integrante voluntária de projetos de pesquisa nas áreas de toxicologia ambiental, hidrologia e gestão de resíduos sólidos.

\section{GUSTAVO HENRIQUE ARAÚJO DOS SANTOS}

Especialista em Energias Renováveis pela Pontifícia Universidade Católica do Rio Grande do Sul (PUCRS), Engenheiro Civil pela Universidade Estadual Paulista (UNESP), Mestrando no Programa de Pós-Graduação em Energia e Sustentabilidade da Universidade Federal de Santa Catarina e Diretor da Secretaria de Planejamento da Prefeitura Municipal de Xangri-Lá/RS. Atua na gestão integrada de resíduos sólidos urbanos, desenvolve e aplica políticas públicas para fomentos das energias renováveis.

\section{GUSTAVO SIMAS PEREIRA}

Professor de Gestão Ambiental e Ecologia do Instituto Federal de Educação, Ciência e Tecnologia do Rio de Janeiro (IFRJ). Doutor em Ciências Ambientais e Florestais pela Universidade Federal Rural do Rio de Janeiro (UFRRJ) e Graduado em Ciências Biológicas (licenciatura) pela 
Universidade Federal do Rio de Janeiro (UFRJ). Coordenador do Grupo de Pesquisa do Núcleo de Meio Ambiente e Sustentabilidade (NUMAS) do IFRJ. Tem experiência em Educação / Ciências Ambientais / Gestão e no Planejamento Ambiental.

\section{HALISON SALIS EUSTAQUIO}

Possui graduação em Engenharia Ambiental e Sanitária pela Faculdade Pitágoras (2016), Especialização em Segurança do Trabalho pela Faculdade Pitágoras (2018) em curso de Mestrado na modalidade de disciplinas Isoladas do Mestrado Profissional em Sustentabilidade e Tecnologia Ambiental (MPSTA) do IFMG Campus Bambuí e técnico em Química Instituto CECON (2009) e técnico em Meio Ambiente pela Escola Técnica Carmo do Cajuru. Atualmente é analista de meio ambiente - Ferrovia Centro - Atlântica S/A. Tem experiência na área de Engenharia Ambiental, Gerenciamento de resíduos sólidos, Gestão de Recursos Hídricos, Educação Ambiental, Requisitos Legais,Gestão de Contratos.

\section{HARLEY MORAES MARTINS}

Engenheiro Químico (IQ-UERJ); Mestre em Engenharia Ambiental (FEN-UERJ); Doutor em Processos Químicos e Meio Ambiente (EQ-UFRJ), Pós Graduado em Engenharia de Segurança e Higiene do Trabalho (UFRJ); Pós Graduado em Gestão da Qualidade e Sanitária (ENSP-FIOCRUZ); Pós Graduado - MBA em Gestão e Tecnologia Ambiental (UCAM/CRQ); Auditor Líder Internacional em Sistemas de Gestão da Qualidade - ISO 9001:2015) e Gestão Ambiental - ISO 14001:2015 (BV Certification / International Register of Certificated Auditors - IRCA); Auditor Sênior em Sistemas de Gestão (International Auditor and Training Certification Association - IATCA); Instrutor de diversos treinamentos, abertos e "in company" em Sistemas de Gestão por diversas instituições nacionais e internacionais; Consultor responsável pela Implantação/adequação de Sistemas de Gestão (QSMS) em diversas empresas; Professor Efetivo e Vice-coordenador do IFRJ na área Ambiental; Presidente da Câmara Técnica de Meio Ambiente (CRQIII); Membro Efetivo do Plenário e de Câmaras Técnicas do Conselho Estadual de Meio Ambiente - CONEMA/RJ; Membro Titular do Plenário e de Câmaras Técnicas do Conselho Municipal de Meio Ambiente -CONSEMAC/RJ; Membro efetivo do Conselho Empresarial de Meio Ambiente da FIRJAN (2010); Conselheiro Titular (1997-2022), Diretor Executivo (1999-2010 e 2013-2020) e Vice-Presidente do Conselho Regional de Química - RJ (2008-2010 e 2013-2014). Foi, ainda, gerente de QSMS (Qualidade/Meio Ambiente/Saúde e Segurança Ocupacional) de diversas empresas de engenharia, entre as quais a SCET Soluções de Engenharia e Tecnologia, a GENPRO Engenharia, a TECHNIP Engenharia, a UTC Projetos e Consultoria, o Consórcio CEB Engenharia, entre outras. Além disso, atuou como funcionário do Sistema Petrobras (Centro de Pesquisas - CENPES e Petrobras Distribuidora - BR) e dos Grupos Bureau Veritas (BV e BVQI) e MBR (Vale).

\section{HUDSON SANTOS DA SILVA}

Doutor em Meio Ambiente (UERJ) professor de Gestão Ambiental do Instituto Federal do Rio de Janeiro atuando na área de Gestão e Políticas Públicas e Gestão da Qualidade.

\section{HYGOR ARISTIDES VICTOR ROSSONI}

Graduado em Engenharia Ambiental pela Universidade Federal de Viçosa (2005), mestre em Ciência Florestal pela mesma instituição (2007) e Doutor em Saneamento, Meio Ambiente e Recursos Hídricos pela Universidade Federal de Minas Gerais (2015). Atualmente é professor da Universidade Federal de Viçosa - Campus de Florestal. Tem experiência na área de Engenharia Sanitária e Ambiental, com ênfase em Controle da Poluição e Saneamento, atuando, principalmente, nos seguintes áreas temáticas: políticas públicas de saneamento, tratamento e reutilização de efluentes ou águas residuárias; gerenciamento de resíduos sólidos, monitoramento e controle ambiental e gerenciamento de recursos hídricos. Recentemente (2017) vem atuando como docente e orientador permanente do Programa de Pós-Graduação em Sustentabilidade e Tecnologia Ambiental (Mestrado Profissional) do Instituto Federal de Minas Gerais - Campus Bambuí, desenvolvendo trabalhos nas linhas de pesquisas referentes a Gestão e Planejamento Ambiental e Tecnologia Ambiental. As orientações estão sendo desenvolvidas nas seguintes áreas 
de interesses: i) Planejamento, Gestão e Avaliação de Políticas Públicas de Saneamento; ii) Tecnologias de Tratamentos de Águas de Abastecimento e Residuárias; e iii) Controle Ambiental em Processos Agrícolas e Industriais.

\section{IAGO CIPRIANO DUTRA}

Bacharel em Ciência e Tecnologia pela Universidade Federal de Alfenas (UNIFAL-MG). Graduando em Engenharia Química pela Universidade Federal de Alfenas, bolsista do Programa de Educação Tutorial (PET), grupo PET Ciência.

\section{ISABELLA MACHADO DE ALMEIDA}

Engenheira de Minas - UFMG. Mestranda em Construção Sustentável - CEFET-MG

\section{IVAN XAVIER LINS}

Engenheiro Químico formado pela Universidade Federal de Pernambuco (2018). Atualmente, é mestrando da Universidade Católica de Pernambuco. Possui experiência na área de Engenharia Sanitária, com ênfase em Tratamento de Águas de Abastecimento e Residuárias, atuando principalmente nos seguintes temas: sustentabilidade, separação óleo/água, separação sólido/líquido, óleos de fritura e meio ambiente. Além disso, atua em Ecoeficiência e Sustentabilidade, otimização de processos, tratamento e reaproveitando efluentes gerados nos processos e agregando valor comercial/ambiental aos resíduos. Também atua na gestão de recursos hídricos e na otimização de fluxos para recebimento e tratamento do óleo de fritura residual. Paralelamente, acompanha a implantação e o dimensionamento da Estação de Tratamento de Efluentes oleosos, gerados pelo tratamento do óleo de fritura residual, para produção de sabão em barra, na empresa ASA Ind. e com. Ltda.

\section{JEANE ESTELA AYRES DE LIMA}

Engenheira Química pela Universidade Federal do Rio Grande do Sul (UFRGS), Mestre em Química pela UFRGS e Doutora em Ciências dos Materiais pelo PGCIMAT/UFRGS. Atua como professora adjunto na Pontifícia Universidade Católica do Rio Grande do Sul (PUCRS) desde 1997. Tem experiência nos seguintes temas: reciclagem de materiais, sequestro de carbono, biomassa e biocombustíveis, tecnologias waste-to-energy.

\section{JOÃO HENRIQUE FERNANDES OLIVEIRA}

Possui ensino médio pelo Colégio Educacional de Itaú de Minas (2015). Formado em Bacharelado em Ciência e Tecnologia (2019), pela Universidade Federal de Alfenas. Atualmente estuda Engenharia de Computação, no Instituto Federal do Sul de Minas Gerais (IF sul de minas) Campus Poços de Caldas - MG.

\section{JULIANNA MULLER DA SILVA}

Formanda de Engenharia Civil na Universidade do Estado do Amazonas, no semestre de 2019/02. Apaixonada pela área ambiental e pela sustentabilidade, enveredou por essa área desde o início do curso. Estagiou dois anos no Tribunal de Contas do Estado do Amazonas, (TCE - AM em 2017 e 2018), e está atualmente estagiando na empresa J Nasser Engenharia Ltda.

\section{LARISSA SANTANA BATISTA}

Possui graduação em Engenharia Civil pela Universidade Federal de Campina Grande (2009) e mestrado em Engenharia Civil e Ambiental pela Universidade Federal de Campina Grande (2012). Atualmente é Docente do Magistério Superior da Universidade Federal de Campina Grande. Doutoranda em Engenharia de Processos pela Universidade Federal de Campina Grande. Tem 
experiência na área de Engenharia Civil, atuando principalmente nos seguintes temas: Geotecnia, Geotecnia ambiental, Estradas, Pavimentação e Transportes.

\section{LEANDRO HENRIQUE PEREIRA}

Possui ensino médio pelo Colégio Tiradentes da Polícia Militar de Passos - MG (2015). Formado em Bacharelado em Ciência e Tecnologia (2019), pela Universidade Federal de Alfenas. Atualmente estuda Engenharia Ambiental, na Universidade Federal de Alfenas (UNIFAL) Campus Poços de Caldas - MG.

\section{LUAN HENRIQUE SOARES}

Possui mestrado em Engenharia Química e graduação em Bacharelado Interdisciplinar em Ciência e Tecnologia e em Engenharia Química pela Universidade Federal de Alfenas - UNIFAL-MG. Atualmente faz doutorado em Engenharia Química pela Universidade Estadual de Campinas na área de simulação e otimização de processos químicos. Tem experiência em áreas relacionadas à simulação e otimização de processos, predição de propriedades termofísicas, biodigestão anaeróbia, simulação numérica e fenômenos de transporte.

\section{MARIA ISABEL DE ARAÚJO NÓBREGA}

É graduanda em Engenharia Civil pela Universidade Federal de Campina Grande.

\section{MARIANE VIVIURKA FERNANDES}

Graduada em Engenharia Ambiental pela Universidade Estadual do Centro Oeste, 2018. Atualmente, atua como residente técnica no Instituto Ambiental do Paraná e cursa Pós Graduação em Engenharia e Gestão Ambiental pela Universidade Estadual de Ponta Grossa

\section{MICHELLE RAMOS CAVALCANTE FORTUNATO}

Engenheira Química (UFRRJ), Química (UFRJ) e Engenheira de Segurança do Trabalho (UFRJ). Mestre em Engenharia Química (EQ/UFRJ). Pós Graduada em Petróleo - Sistemas Offshore (COPPE/UFRJ). Pós Graduada em Perícia pela Universidade Castelo Branco. Membro efetivo da Câmara Técnica de Meio Ambiente (CRQ -III). Tem experiência na indústria química nas áreas de Engenharia e Meio Ambiente/Segurança e análise de Estudos de Riscos Ambientais e Planos de Emergências de estaleiros, terminais portuários, refinarias, bases de apoio offshore e bases de armazenamento de combustíveis. Docente do ensino técnico em Segurança do Trabalho. Produtora de Conteúdos Técnicos.

\section{MOHAND BENACHOUR}

Possui graduação em Engenharia Química - Ecole Nationale Polytechnique D Alger (1984), mestrado em Genie Biologique - Universitè de Technologie de Compiègne (1985) e doutorado em Génie Des Procédés - Institut National Polytéchnique de Lorraine (1990). Atualmente é professor titular da Universidade Federal de Pernambuco. Tem experiência na área de Engenharia Química, com ênfase em Reatores Químicos, atuando principalmente nos seguintes temas: gás natural, modelagem cinética, fenol, adsorção e oxidação avançada.

\section{MÔNICA DA CUNHA E SILVA}

Engenheira de Produção Civil - UTFPR. Mestranda em Construção Sustentável - CEFET-MG 


\section{MUIRA HELENA BATISTA}

Pesquisadora associada ao LATACI@ Research Institute. Mestre em Administração pelo Centro Universitário UNA; Pós-graduação Lato Sensu MBA Executivo em Negócios Financeiros pela Pontifícia Universidade Católica do Rio de Janeiro e Graduação em Ciências Econômicas pelo Centro Universitário do Triângulo.

\section{NATHANA CIPRIANO ULCHAK}

Graduanda em Engenharia Ambiental pela Universidade Estadual do Paraná

\section{PÁGLIA SILVA LOPES SANTOS}

Pós Graduada com MBA em Gestão de Comércio Exterior e Negócios Internacionais pela FGV (2005). Especialista em Docência no Ensino Superior (2008). Graduada em Administração com Ênfase em Comércio Exterior (2003). Experiência de onze (11) anos como docente no ensino superior nos cursos de Administração, Agronomia, Gestão Pública, Comércio Exterior e outros. Atualmente empreende na área de prestação de serviços mecânicos industriais e atua como docente na Escola de Formação Gerencial EFG - Sebrae em Arcos MG.

\section{PÂMELA DE MEDEIROS ENGELMANN}

Possui técnico em biocombustíveis pelo Instituto Federal Sul-Rio-Grandense - campus Pelotas. É graduada em Engenharia Agroindustrial Agroquímica pela Universidade Federal do Rio Grande. Bolsista PET conexão dos saberes de 2010 à 2014. É mestre em engenharia e tecnologia de materiais com enfase em mitigações de impactos ambientais, onde atuou na determinação de impactos ambientais em área de aterro sanitário. Atualmente cursa doutorado em engenharia e tecnologia de materiais com enfase em mitigações de impactos ambientais em aplicações de wasteto-energy.

\section{PEDRO ROCHA DA ROCHA}

Graduando em Química pela Pontifícia Universidade Católica do Rio Grande do Sul. Foi bolsista do Programa de Educação Tutorial (PET-QUÍMICA) e do Programa Institucional de Bolsa de Iniciação à Docência - PIBID. Também foi estagiário do Projeto Energia e Produtos a partir dos Resíduos de Xangri-lá.

\section{RAFAEL DE OLIVEIRA TIEZZI}

Graduado em Engenharia Ambiental pela UNESP - Universidade Estadual Paulista Júlio de Mesquita Filho (2006), pós graduado em Avaliação Ambiental pelo Prominp/UNICAMP/Pétrobrás, Mestre em Planejamento Energético pelo Departamento de Energia da UNICAMP na área de Mudanças Climáticas e recursos hidroenergéticos e doutor em Recursos Hídricos, Energéticos e Ambientais na Faculdade de Engenharia Civil da Unicamp, onde trabalha com impactos hidroclimatologicos sobre riscos de suprimento energético do SIN. Rafael foi pesquisador do Instituto de Pesquisas Tecnológicas de São Paulo (IPT) no Laboratório de Recursos Hídricos e Avaliações Geoambientais (LABGEO-CETAE). Foi analista operacional em hidrologia no Centro Nacional de Monitoramento e Alerta de Desastres Naturais (Cemaden) do Ministério da Ciência, Tecnologia e Inovação (MCTI) do Brasil, perito judicial de promotoria, Coordenador de Meio Ambiente da empresa Semp-Toshiba e consultor de implantação de SGA-ISO 14.001 na Sabesp. Atualmente é Professor no Instituto de Ciência e Tecnologia-ICT (campus de Poços de Caldas-MG) da Universidade Federal de Alfenas. 


\section{ROGÉRIO VESCIA LOUREGA}

Químico Industrial pela Universidade Federal de Santa Maria (UFSM), Doutor em Química pela UFSM. Atua como professor adjunto na Pontifícia Universidade Católica do Rio Grande do Sul (PUCRS) desde 2008. Tem experiência nos seguintes temas: síntese de compostos orgânicos, reciclagem de materiais, sequestro de carbono, biomassa e biocombustíveis (biorrefinaria), tecnologias waste-to-energy.

\section{SÍLVIA CARLA DA SILVA ANDRÉ UEHARA}

Professora Adjunta II do Departamento de Enfermagem da Universidade Federal de São Carlos. Aperfeiçoamento no Environmental \& Occupational Medicine \& Epidemiology Program, Department of Environmental Health, School of Public Health of Harvard University (2015). Doutora em Saúde Pública, pela Escola de Enfermagem de Ribeirão Preto da Universidade de São Paulo (2014) com período de estágio no exterior, realizado na Escola Nacional de Saúde Pública da Universidade Nova de Lisboa. Mestre em Saúde Pública, pela Escola de Enfermagem de Ribeirão Preto da Universidade de São Paulo (2011). Especialista em Saúde Pública e Gestão em Saúde, pela Universidade de Alfenas (2009), graduada em Enfermagem pela Universidade do Estado de Minas Gerais (2006). Membro do GRUPO DE ESTUDOS: POLÍTICAS E PRÁTICAS EM SAÚDE e do Grupo Insterinstitucional de Estudo da Problemática dos Resíduos de Serviços de Saúde de Ribeirão Preto. Temas de atuação: saúde pública; saúde ambiental, epidemiologia e resíduos de serviços de saúde e gerenciamento de riscos não-clínicos.

\section{SOSTENES DE SOUZA MOREIRA}

Graduado Tecnólogo em da Gestão da Produção Industrial e Pós-graduado em Engenharia de Produção pelo Centro Universitário Internacional UNINTER, formado Técnico em Mineração pelo CEFET - PA, Graduando Bacharelado em Engenharia de Minas pela UFOPA. Já atuou como técnico em Geologia em outras empresas de mineração. Atualmente atua como Técnico de Qualidade Especialista na empresa AWA - Alcoa World Alumina Brasil. Interessa -se por empresas de Mineração e de Produção Industrial.

\section{TACIANE STRICKLER DUTRA}

Vida profissional: sócia proprietária na empresa Madeireira \& Ferragem União, fundada em 2007; Sócia proprietária na empresa Union engenharia, fundada em 2018. Prestadora de serviço como engenheira civil na empresa Alta Vista Inc \& Const. Vida acadêmica e publicações: formada em 2018 no curso de bacharel em Engenharia Civil pela UNISINOS. Participação no diretório acadêmico de eng civil da Universidade nos anos de 2016, 2017 e 2018. Possuo cursos extensivos, por exemplo, Formação de Auditores Internos ISO 9001 e SiAC, Autocad, Utilização de Estruturas de Concreto Armado Pré-fabricadas e outros. Participações nos congressos ENEC 2017 e COLEIC 2016. Publicação de artigo no CONRESOL 2019.

\section{TATIANE BONAMETTI VEIGA}

Professora Adjunta B do Departamento de Engenharia Ambiental (DENAM) da UNICENTRO. Docente do programa de Pós-graduação em Engenharia Sanitária e Ambiental . Graduação em Engenharia Civil pela Universidade Estadual de Londrina (1996), Mestre (2011) e Doutora (2014) em Ciências no Programa em Saúde Pública na Universidade de São Paulo em Ribeirão Preto. Membro efetiva do Grupo Interinstitucional de Estudo da Problemática dos Resíduos de Serviços de Saúde de Ribeirão Preto e do Grupo de Saneamento Ambiental e Recursos Hídricos na Universidade Estadual do Centro-Oeste do Paraná. Atua na área de Saneamento Ambiental, com ênfase em Gestão e Gerenciamento de Resíduos Sólidos Urbanos, Resíduos de Serviços de Saúde e Saúde Pública. 


\section{THIAGO DA NÓBREGA SOUSA}

Possui graduação em Engenharia civil pela Universidade Federal de Campina Grande e técnico em Manutenção de Microcomputadores. Já atuou como Diretor de Marketing da Pórtico Engenharia Júnior, como estagiário de engenharia civil na Prefeitura Municipal de Pombal e desenvolveu pesquisa de iniciação cientifica (CNPQ/PIBIC) durante um ano. Grande habilidade no pacote Office, domínio intermediário do inglês e perfil de profissional empenhado, com facilidade para trabalhar em equipe.

\section{THYAGO LIMA SOUZA}

Possui graduação em Engenharia Civil pela Universidade Federal de Campina Grande (2019). Atua na elaboração de orçamentos e projetos arquitetônicos, estruturais, elétricos e hidráulicos, bem como no acompanhamento de obras diversas. 


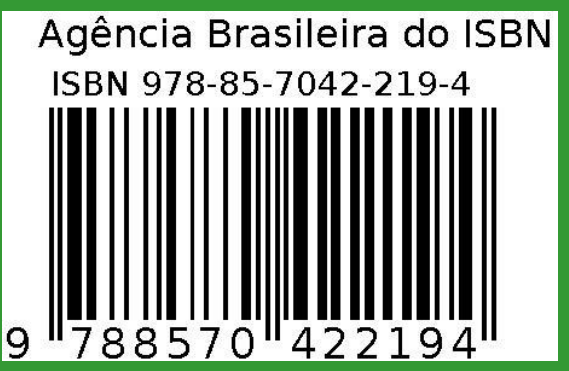

